DOE/OR/01-1471/V1\&D1

$$
\text { ORNL/M- } 5307 / \mathrm{VI}
$$

\title{
Remedial Site Evaluation Report for the Waste Area Grouping 10 Wells Associated with the New Hydrofracture Facility at Oak Ridge National Laboratory, Oak Ridge, Tennessee
}

\section{Volume 1: Evaluation, Interpretation, and Data Summary}

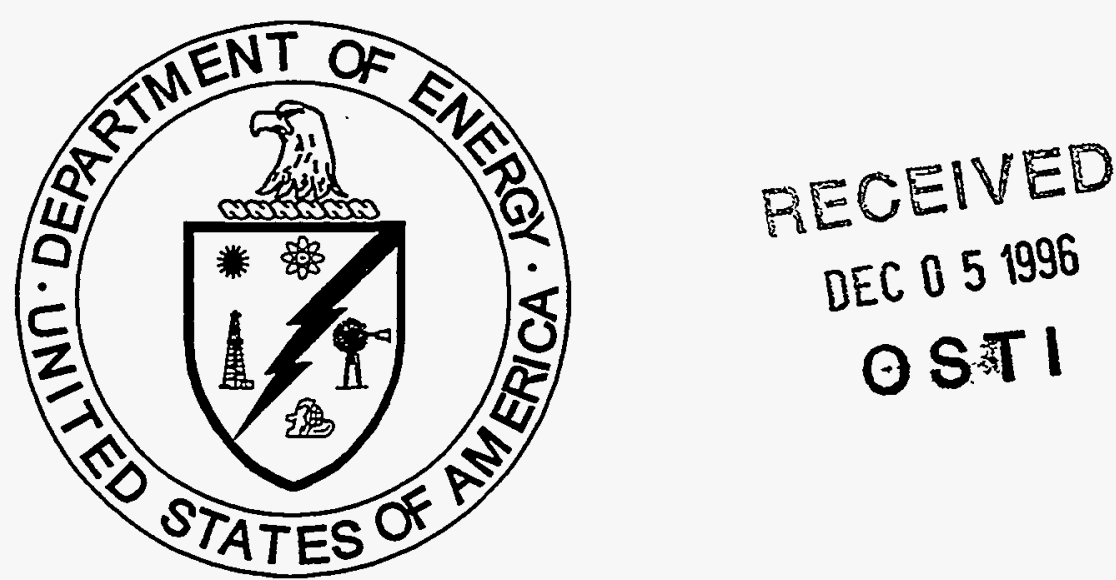

\section{MASTER}

This document has been approved by the ORNL Technical Information Office for release to the public. Date: $8 / 15 / 96$ 


\section{Bechtel National, Inc/CH2M Hill/OGDEN/PEER}

contributed to the preparation of this document and should not be considered eligible contractors for its review.

This report has been reproduced directly from the best available copy.

Available to DOE and DOE contractors from the Office of Scientific and Technical Information, P.O. Box 62, Oak Ridge, TN 37831; prices available from 423-576-8401 (fax 423-576-2865).

Available to the public from the National Technical Information Service, U.S. Department of Commerce, 5285 Port Royal Rd., Springfield, VA 22161. 
Energy Systems Environmental Restoration Program

\author{
Remedial Site Evaluation Report \\ for the Waste Area Grouping 10 Wells \\ Associated with the New Hydrofracture Facility \\ at Oak Ridge National Laboratory, \\ Oak Ridge, Tennessee
Volume 1: Evaluation, Interpretation, and Data Summary

Date Issued-August 1996

\author{
Prepared by \\ Bechtel National, Inc./CH2M Hill/OGDEN/PEER \\ Oak Ridge, Tennessee \\ under subcontract 30B-99053C \\ Prepared for the \\ U.S. Department of Energy \\ Office of Environmental Management \\ under budget and reporting code EW 20 \\ Environmental Management Activities at \\ OAK RIDGE NATIONAL LABORATORY \\ Oak Ridge, Tennessee 37831-6285 \\ managed by \\ LOCKHEED MARTIN ENERGY SYSTEMS, INC. \\ for the \\ U.S. DEPARTMENT OF ENERGY \\ under contract DE-AC05-84OR21400
}





\section{DISCLAIMER}

Portions of this document may be illegible in electronic image products. Images are produced from the best available original document. 


\section{PREFACE}

This document, Remedial Site Evaluation Report for the Waste Area Grouping 10 Wells Associated with the New Hydrofracture Facility at Oak Ridge National Laboratory, Oak Ridge, Tennessee, Volume 1. Evaluation, Interpretation, and Data Summary, DOE/OR/01-1471/V1\&D1, was prepared in accordance with requirements under the Comprehensive Environmental Response, Compensation, and Liability Act for reporting the results of a site evaluation for review. This work was performed under Work Breakdown Structure 1.4.12.6.1.10.42, Activity Data Sheet 3310, "WAG 10." Publication of this document meets a Task Work Agreement amended milestone of August 19, 1996. This document provides the Environmental Restoration Program with information about the results of an evaluation of WAG 10 wells associated with the New Hydrofracture Facility at Oak Ridge National Laboratory. Information provided in this document forms the basis for decisions regarding the need for subsequent action at WAG 10. 



\section{CONTENTS}

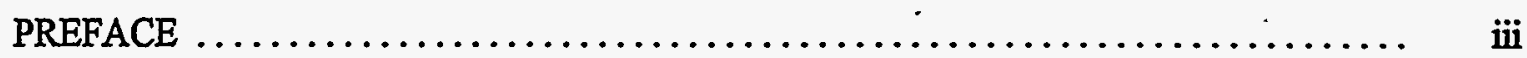

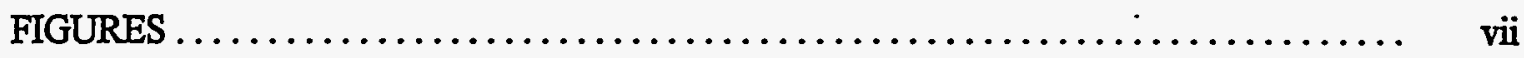

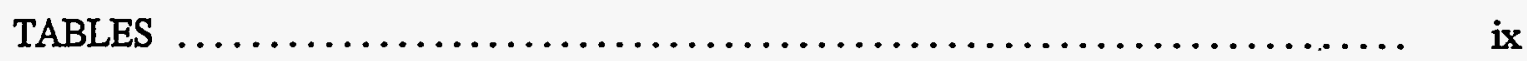

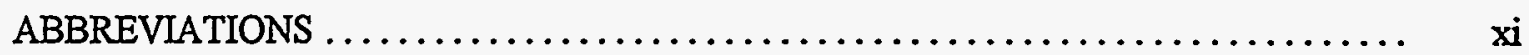

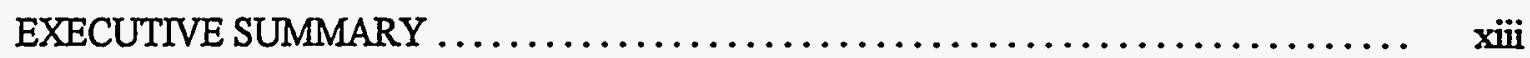

1. INTRODUCTION $\ldots \ldots \ldots \ldots \ldots \ldots \ldots \ldots \ldots \ldots \ldots \ldots \ldots \ldots \ldots \ldots, 1-1$

1.1 HYDROFRACTURE OPERATIONS $\ldots \ldots \ldots \ldots, \ldots \ldots \ldots \ldots \ldots \ldots, 1-2$

1.2 PROGRAMMATIC SETTING $\ldots \ldots \ldots \ldots \ldots \ldots \ldots \ldots \ldots \ldots \ldots \ldots \ldots \ldots, 1-3$

1.3 PREVIOUS WORK AND DOCUMENTATION....................... $1-3$

1.4 SITE EVALUATION AND WELL P\&A OBJECTIVES $\ldots \ldots \ldots \ldots \ldots \ldots, 1-5$

1.5 REPORT ORGANIZATION AND SCOPE $\ldots \ldots \ldots \ldots \ldots \ldots \ldots \ldots \ldots \ldots \ldots \ldots \ldots \ldots \ldots$

2. SITE OPERATIONAL HISTORY $\ldots \ldots \ldots \ldots \ldots \ldots \ldots \ldots \ldots \ldots \ldots \ldots \ldots \ldots \ldots \ldots \ldots \ldots, 2-1$

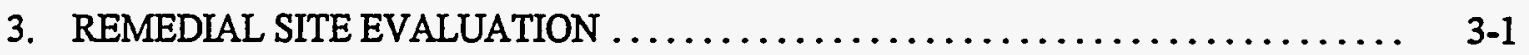

4. HYDROGEOLOGIC SETTING $\ldots \ldots \ldots \ldots \ldots \ldots \ldots \ldots \ldots \ldots \ldots \ldots \ldots \ldots, 4,1$

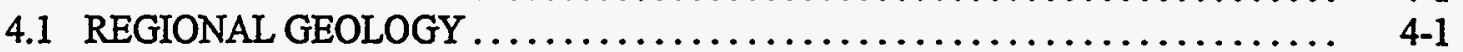

4.2 SITE GEOLOGY $\ldots \ldots \ldots \ldots \ldots \ldots \ldots \ldots \ldots \ldots \ldots \ldots \ldots \ldots \ldots, \quad 4,1$

4.3 GROUNDWATER HYDROLOGY $\ldots \ldots \ldots \ldots \ldots \ldots \ldots \ldots \ldots \ldots \ldots, 4,4$

4.3.1 Regional Characteristics ................................ $4-4$

4.3.2 Site Characteristics $\ldots \ldots \ldots \ldots \ldots \ldots \ldots \ldots \ldots \ldots \ldots \ldots \ldots \ldots \ldots \ldots \ldots \ldots, 4-4$

4.3.3 Groundwater Circulation Patterns and Specific Discharges ............ 4-4

4.4 GROUNDWATER GEOCHEMISTRY $\ldots \ldots \ldots \ldots \ldots \ldots \ldots \ldots \ldots \ldots \ldots, \quad 4-6$

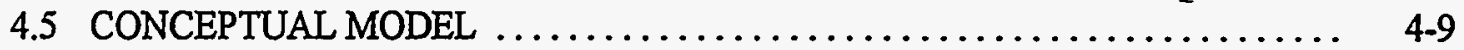

4.5.1 Potential Exposure and Transport Mechanisms and Pathways .......... 4-9

4.5.2 New Hydrofracture Facility Operating Conditions ................ 4-11

4.5.3 New Hydrofracture Facility Operations Site Monitoring Activities ....... 4-12

4.5.4 Distribution of Contamination $\ldots \ldots \ldots \ldots \ldots \ldots \ldots \ldots \ldots \ldots \ldots, \quad 4-14$

4.5 .5 Summary $\ldots \ldots \ldots \ldots \ldots \ldots \ldots \ldots \ldots \ldots \ldots \ldots \ldots \ldots \ldots, 4-17$

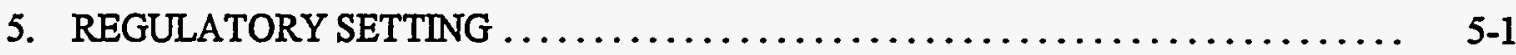

5.1 WASTE CHARACTERIZATION $\ldots \ldots \ldots \ldots \ldots \ldots \ldots \ldots \ldots \ldots \ldots \ldots, 5,1$

5.2 WASTE DISPOSAL $\ldots \ldots \ldots \ldots \ldots \ldots \ldots \ldots \ldots \ldots \ldots \ldots \ldots \ldots \ldots, 5,1$

5.3 FUGITIVE EMISSIONS $\ldots \ldots \ldots \ldots \ldots \ldots \ldots \ldots \ldots \ldots \ldots \ldots \ldots \ldots \ldots, \quad 5-1$

5.4 STORM WATER CONTROL $\ldots \ldots \ldots \ldots \ldots \ldots \ldots \ldots \ldots \ldots \ldots \ldots \ldots, \quad 5-2$

5.5 PLUGGING AND ABANDONMENT $\ldots \ldots \ldots \ldots \ldots \ldots \ldots \ldots \ldots \ldots \ldots, 5-2$

5.5 .1 Overview $\ldots \ldots \ldots \ldots \ldots \ldots \ldots \ldots \ldots \ldots \ldots \ldots \ldots \ldots \ldots, \quad 5-2$

5.5.2 Implementation Requirements $\ldots \ldots \ldots \ldots \ldots \ldots \ldots \ldots \ldots \ldots \ldots, \quad 5-3$ 



\section{FIGURES}

1.1 Maps showing the Department of Energy Oak Ridge Reservation and four

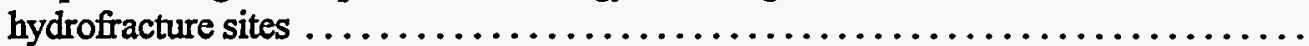

2.1 Aerial view of hydrofracture operations and related wells $\ldots \ldots \ldots \ldots \ldots \ldots \ldots \ldots$

2.2 Locations of hydrofracture-related wells ......................... 2-6

2.3 Summary of volume and activities injected at New Hydrofracture Facility ........ 2-7

2.4 Final configuration of the New Hydrofracture Facility injection well $\ldots \ldots \ldots \ldots \ldots .2-8$

2.5 Ground surface uplift at the New Hydrofracture Facility $\ldots \ldots \ldots \ldots \ldots \ldots \ldots \ldots .2-9$

4.1 Geohydrologic map for the Oak Ridge Reservation .................... 4-19

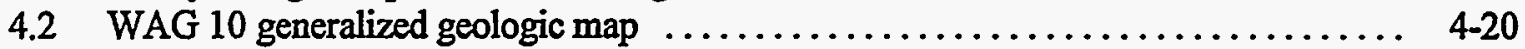

4.3 Stratigraphic section in East Fork Valley, East Fork Ridge and Pilot Knob, Pine Ridge, Bear Creek Valley, and Chestnut Ridge ................. 4-21

4.4 Structural and topographic controls for artesian flow at WAG $10 \ldots \ldots \ldots \ldots \ldots$ 4-22

4.5 Total head measurements in WAG 10 New Hydrofracture Facility wells

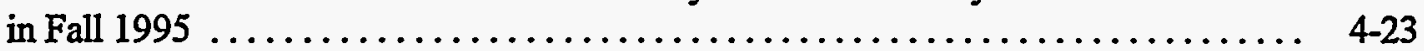

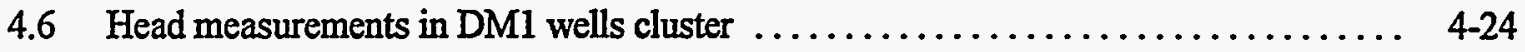

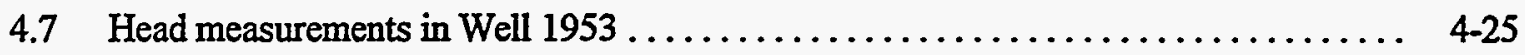

4.8 Piper diagram using geometric mean values of selected ions from historic

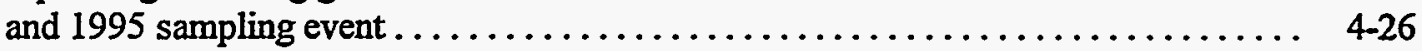

4.9 Temperature, conductivity, and $\mathrm{pH}$ results for New Hydrofracture wells $\ldots \ldots \ldots \ldots$ 4-27

4.10 Chemistry of standing water column in New Hydrofracture Facility

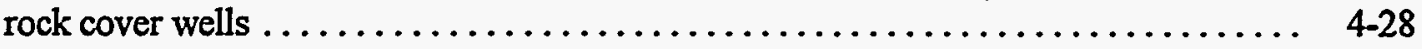

4.11 Chemistry of standing water column in New Hydrofracture Facility deep monitoring wells

4.12 Schematic representation of possible migration pathways

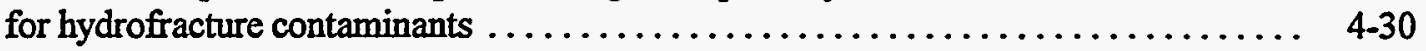

4.13 Depth of activity injected at the New Hydrofracture Facility $\ldots \ldots \ldots \ldots \ldots \ldots .4 .6 \ldots$

4.14 Comparison of waste injected at the Old Hydrofracture Facility

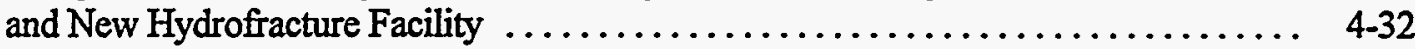

4.15 Summary of desired and actual waste mix ratios used for injections

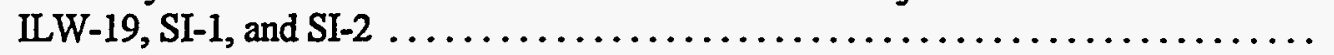

4.16 Summary of desired and actual waste mix ratios used for injections

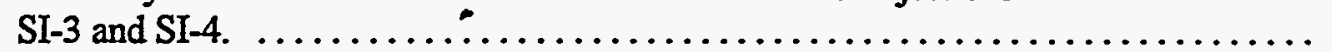

4.17 Summary of desired and actual waste mix ratios used for injections SI-5, IIW-20, SI-6, and SI-7.

4.18 Summary of desired and actual waste mix ratios used for injections

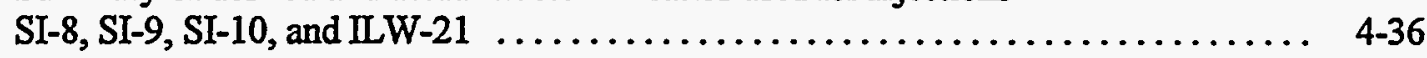

4.19 Pressure measured in rock cover wells during injections $\ldots \ldots \ldots \ldots \ldots \ldots \ldots \ldots . . \ldots \ldots \ldots$

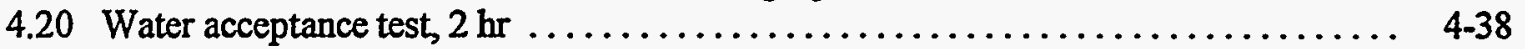

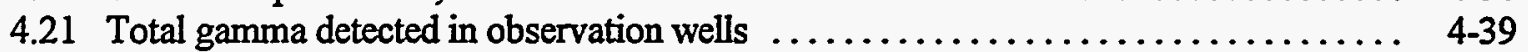

4.22 Extent of grout sheets in the Pumpkin Valley Shale $\left(A-A^{\prime}\right) \ldots \ldots \ldots \ldots \ldots \ldots \ldots .440$

4.23 Extent of grout sheets in the Pumpkin Valley Shale (B-B') . . . . . . . . . . . $4-41$

4.24 Historic $\mathrm{pH}$ in rock cover and deep monitoring wells .................. $4-42$

4.25 Total dissolved solids in selected New Hydrofracture Facility wells $\ldots \ldots \ldots \ldots \ldots \ldots$. $4-43$

4.26 Total gamma activity in selected New Hydrofracture Facility wells ............ 4 4-44

4.27 Gross beta activity in selected New Hydrofracture Facility wells $\ldots \ldots \ldots \ldots \ldots \ldots$. $4-45$ 


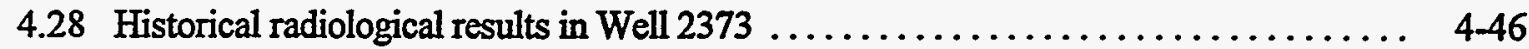

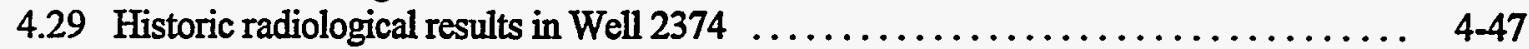

4.30 Historical and recent gamma logs collected from Well $2373 \ldots \ldots \ldots \ldots \ldots \ldots \ldots$. . . 48

4.31 Comparison of gamma logs from Well 2373 and Well $2954 \ldots \ldots \ldots \ldots \ldots \ldots \ldots$. $4-49$

4.32 Historical and recent gamma logs collected from Well $2374 \ldots \ldots \ldots \ldots \ldots \ldots \ldots$. $4-50$

6.1 Conceptual design of plugging options in rock cover and observation wells ........ 6-23

6.2 Selection of plugging and abandonment method for WAG 10 wells ........... $6-24$

6.3 Example hypothetical temperature logs under various behind-casing

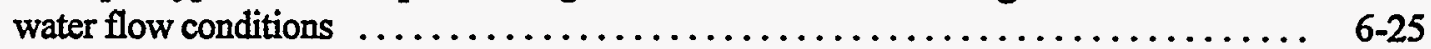

7.1 Well ranking for New Hydrofracture Facility, Old Hydrofracture Facility,

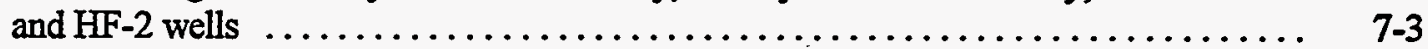




\section{TABLES}

1.1 Summary of hydrofracture grout injections $\ldots \ldots \ldots \ldots \ldots \ldots \ldots \ldots \ldots \ldots, 1-9$

1.2 Field measurements and Close Support Laboratory analytes ................ 1-10

2.1 Radionuclide content of waste injections conducted at the

New Hydrofracture Facility $\ldots \ldots \ldots \ldots \ldots \ldots \ldots \ldots \ldots \ldots \ldots \ldots \ldots \ldots \ldots \ldots, 2-10$

2.2 Composition of dry solids used for New Hydrofracture Facility waste/grout mixtures $\ldots \ldots \ldots \ldots \ldots \ldots \ldots \ldots \ldots \ldots \ldots \ldots \ldots \ldots \ldots \ldots \ldots \ldots \ldots \ldots, 2-13$

2.3 New Hydrofracture Facility injection volumes and mixing ratios .............. 2-14

2.4 Summary of waste/grout volumes and radionuclide content injected at the New Hydrofracture Facility $\ldots \ldots \ldots \ldots \ldots \ldots \ldots \ldots \ldots \ldots \ldots \ldots, 2-16$

2.5 WAG 10 New Hydrofracture Facility well construction details ................ 2-17

2.6 Rock cover well pressure tests conducted at the New Hydrofracture Facility $\ldots \ldots \ldots . \quad 2-18$

2.7 Water acceptance tests conducted at the New Hydrofracture Facility ........... 2-22

4.1 Close Support Laboratory analytical data summary for $\mathrm{pH}$, alkalinity, total dissolved solids, and total suspended solids ..................... 4-51

4.2 Close Support Laboratory analytical data summary for cations and anions

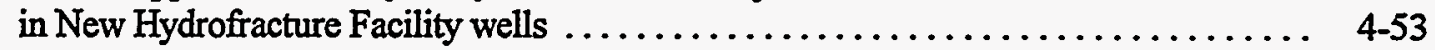

4.3 Close Support Laboratory analytical data summary for radionuclides in New Hydrofracture Facility wells ........................... 4-55

4.4 Historical sample analyses for $\mathrm{pH}$, alkalinity, conductivity, total dissolved solids,

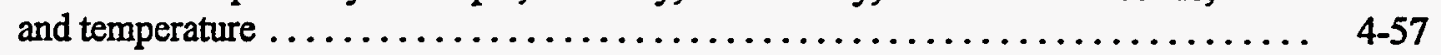

4.5 Historical sample analyses for cations and anions in New Hydrofracture Facility wells $\ldots \ldots \ldots \ldots \ldots \ldots \ldots \ldots \ldots \ldots \ldots \ldots \ldots . \ldots \ldots, 4-59$

4.6 Historical sample analyses for radionuclides in

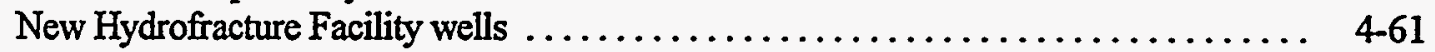

4.7 Bleedback data collected during injections and mix ratio evaluation at the New Hydrofracture Facility $\ldots \ldots \ldots \ldots \ldots \ldots \ldots \ldots \ldots \ldots \ldots \ldots, 4,63$

4.8 New Hydrofracture Facility grout sheet intersects with observation wells $\ldots \ldots \ldots \ldots, 4.64$

5.1 Regulations for plugging and abandonment of WAG 10 wells $\ldots \ldots \ldots \ldots \ldots \ldots$. $5-5$

5.2 Minimum specified state requirements for P\&A of UIC-qualified wells, TDEC 1200-4-6-.09, Paragraphs (6)(d) through (8)(b) ................. $5-7$

6.1 Response action screening summary $\ldots \ldots \ldots \ldots \ldots \ldots \ldots \ldots \ldots \ldots \ldots \ldots \ldots \ldots \ldots \ldots, 6,26$

6.2 Comparison of plugging and abandonment methods ..................... 6-27

6.3 Summary of well P\&A approaches for different well types .................. 6-29

6.4 Estimated waste volumes for proposed plugging and abandonment $\ldots \ldots \ldots \ldots \ldots \ldots, 6-30$

7.1 Summary of well $\log$ and well water chemical information $\ldots \ldots \ldots \ldots \ldots \ldots . \quad 7-4$

7.2 Qualitative ranking of the Old Hydrofracture Facility, New Hydrofracture Facility,

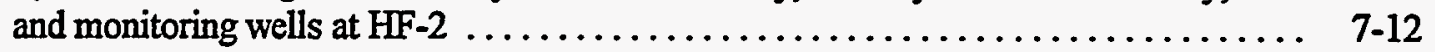

7.3 Classification of New Hydrofracture Facility, Old Hydrofracture Facility, and monitoring wells at $\mathrm{HF}-2 \ldots \ldots \ldots \ldots \ldots \ldots \ldots \ldots \ldots \ldots \ldots \ldots \ldots \ldots \ldots \ldots \ldots, \quad 7-13$ 
. 


\section{ABBREVIATIONS}

AOC area of contamination

API

ARAR

American Petroleum Institute

ASTM

applicable or relevant and appropriate requirement

$\begin{array}{ll}\text { bgs } & \text { below ground surface } \\ \text { BNI } & \text { Bechtel National, Inc. } \\ \text { BOC } & \text { bottom of casing }\end{array}$

CAA Clean Air Act

CERCLA Comprehensive Environmental Response, Compensation, and Liability Act of 1980

CFR

Code of Federal Regulations

CLP

Contract Laboratory Programs

CSL Close Support Laboratory

D\&D decontamination and decommissioning

DAW dry, active waste

DOE U.S. Department of Energy

DM deep monitoring

EDS energy dispersive $\mathrm{x}$-ray analyzer system

EMI external mechanical integrity

EPA U.S. Environmental Protection Agency

EPP excavation and penetration permit

ER Environmental Restoration Program

ESD Environmental Sciences Division

FFA Federal Facility Agreement

FR Federal Register

FSP field sampling plan

$H \& S \quad$ health and safety

HEPA high-efficiency particulate air

HF-1 \& -2 Hydrofracture Experiment Sites 1 and 2

HF-3 Old Hydrofracture Facility

HF-4 New Hydrofracture Facility

ID inside diameter

IDW investigation-derived waste

IIW intermediate-level waste

LEL lower explosive limit

LLLW liquid low-level waste

MCL maximum contaminant level 


\begin{tabular}{|c|c|}
\hline NEPA & National Environmental Policy Act \\
\hline NESHAP & National Emission Standards for Hazardous Air Pollutant \\
\hline NHF & New Hydrofracture Facility \\
\hline NPDES & National Pollutant Discharge Elimination System \\
\hline NRWTP & Nonradiological Wastewater Treatment Plant \\
\hline OHF & Old Hydrofracture Facility \\
\hline ORNL & Oak Ridge National Laboratory \\
\hline ORR & Oak Ridge Reservation \\
\hline OU & operable unit \\
\hline P\&A & plugging and abandonment \\
\hline PWTP & Process Waste Treatment Plant \\
\hline QA & quality assurance \\
\hline QC & quality control \\
\hline RCRA & Resource Conservation and Recovery Act of 1976 \\
\hline RI/FS & remedial investigation/feasibility study \\
\hline RWP & radiation work permit \\
\hline SCSR & site evaluation summary report \\
\hline SDWA & Safe Drinking Water Act \\
\hline SEM & scanning electron microscopy \\
\hline SP & spontaneous potential \\
\hline SPR & single-point resistance \\
\hline SWSA & solid waste storage area \\
\hline TAL & Target Analyte List \\
\hline TCL & Target Compound List \\
\hline TCLP & toxicity characteristic leaching procedure \\
\hline TD & total depth \\
\hline TDEC & Tennessee Department of Environment and Conservation \\
\hline TDS & total dissolved solids \\
\hline TRU & transuranics \\
\hline TSS & total suspended solids \\
\hline TWO & Texas World Operations \\
\hline UIC & underground injection control \\
\hline USDW & underground source of drinking water \\
\hline VDL & variable density log \\
\hline VLA & very low activity \\
\hline WAC & waste acceptance criteria \\
\hline WAG & waste area grouping \\
\hline WM & waste management \\
\hline
\end{tabular}




\section{EXECUTIVE SUMMARY}

Four hydrofracture sites at the Oak Ridge National Laboratory in Oak Ridge, Tennessee, were used for development, demonstration, and full-scale disposal operations from 1959 to 1984:

- HF-1, Hydrofracture Experiment Site (also known as the 4-acre site), and HF-2, Hydrofracture Experiment Site, demonstrated the hydrofracture concept.

- HF-3, the Old Hydrofracture Facility (OHF) conducted pilot-scale testing followed by operational waste disposal.

- $\quad \mathrm{HF}-4$, the New Hydrofracture Facility (NHF), operated and was designed as a full-scale disposal system for liquid low-level waste and tank sludge.

More than $50,000 \mathrm{yd}^{3}$ (10.1 million gal) of waste grout mix containing approximately 1.4 million $\mathrm{Ci}$ of radioactivity was disposed of via hydrofracture through a series of 43 injections at HF-3 and HF-4. Various types of wells installed to monitor the performance of hydrofracture operations compose Waste Area Grouping (WAG) 10, Wells and Boreholes. Disposal activities were discontinued at NHF in 1984.

The primary goal of this remedial site evaluation was to gain sufficient data about the wells associated with NHF activities to recommend the type and best method of final disposition [plugging and abandonment (P\&A)] for the wells. To meet this goal, a full suite of borehole geophysical logs (mechanical, electrical, nuclear, temperature, resistivity, and acoustic) was run in the wells to:

- determine the well casing bond and casing integrity,

- confirm and extract construction details for each well,

- evaluate the extent of contamination sourced from the NHF grout sheets,

- assist in planning for future P\&A activities at NHF, and

- determine the suitability of the wells for future temporary site monitoring.

The secondary goals were to determine the stratigraphic position of the rock cover, deep monitoring, and observation wells; the subsurface stratigraphy at NHF; and identify possible artificially induced or natural pathways for the spread of contaminants from hydrofracture activities. Screening-level geochemical characterization of the wellbore water was performed to support the primary and secondary goals and the management of wastes generated during future P\&A activities.

This study investigated and evaluated 21 NHF wells. Of those, one well (Well 1970) was not accessible because of small-diameter tubing, but it was evaluated based on a review of historical reports and data. Another well (Well 1972) was sampled but could not be logged because of a bent well riser. Investigation of Injection Well 1968 was not within the scope of this task.

All 21 wells were ranked along with the 25 wells previously studied at OHF to establish a priority for future hydrofracture well P\&A activities. All wells were compared with each other but were not evaluated relative to quantitative human health or ecological risk criteria. Six of the NHF 
wells $(2954,1970,1972,1978,1975$, and 2955) received the highest rankings (9) and should be plugged and abandoned as soon as possible.

Five of the NHF wells $(1969,1973,1974,2952$, and 2375) provide an opportunity for retrofitting and temporary sampling/pressure monitoring at the hydrofracture site; these wells have open hole intervals that cover the Rogersville Shale, Rutledge Limestone, and upper Pumpkin Valley Shale (injection zone).

Geologic cross sections were constructed for the NHF area, using newly acquired geophysical data and historic information, and tied to the $\mathrm{OHF}$ site. Interpretations of these and other acquired data reveal that several mechanisms have been active in the spread of radioactive contaminants associated with NHF operations. These are as follows.

- A highly contaminated filtrate plume surrounds the grout sheets within the injection horizon. New gamma ray peaks show evidence that this plume has migrated since the close of operations at NHF. The plume extends $<1000 \mathrm{ft}$ to the north and $>1000 \mathrm{ft}$ to the east and west of the injection well. The extent of contamination to the south, east, and west are unknown. No natural surface expression is known.

- All of the observation wells that penetrate the injection interval were intercepted by grout sheets during NHF operations and are contaminated with grout and/or grout filtrate (aqueous radionuclides). The NHF observation wells provide a potential pathway for migration of contaminants.

- Minor radiological contamination is present in the units that overlie the injection horizon (Rogersville Shale/Rutledge Limestone). Radiological contamination in the rock cover wells is likely due to upward migration from the injection zone and past cross contamination.

- Radiological contamination in the standing water column in deep monitoring wells (2373 and 2374) penetrating into the Rome Formation is "relic" and does not represent downward migration from the grout sheets.

- Most of the wellbores (with the exception of the NHF observation wells) provide a pathway for the upsection migration of high-salinity natural brine.

- Pressurized conditions were encountered in several wells that were intercepted by the grout sheets. The existence of pressure in the injection horizon provides the gradient necessary to create a dynamic groundwater flow system, thereby facilitating migration of contaminants.

The objectives of the P\&A options analysis were to select the best method of:

- protecting health, safety, and the environment;

- protecting the shallow freshwater zone (upper Maryville Limestone) and the underlying highly saline zone (Rome Formation);

- isolating the injection horizon (upper Pumpkin Valley Shale); and

- minimizing exposure risks, waste generation, and costs from P\&A operations.

These objectives were satisfied by using the same P\&A technical approach as used for the study of OHF-associated wells. The approach is summarized below. 
For cased wells with external mechanical integrity (EMI) and no evidence of flow behind casing, the preferred P\&A approach is to leave the well casing in place and fill the entire well in stages with cement. Hydraulic pressure will be applied as needed to force or "squeeze" the cement slurry into formation voids and around casing shoes. The well casing will be pressure-tested to check casing integrity before this method is used to plug and abandon a well.

For those cased wells that do not have EMI or for which EMI cannot be confirmed, the preferred P\&A approach depends primarily on the well casing inside diameter. If the diameter is large enough ( $>2.5$ in.) to accept standard P\&A tools and equipment, the casing and grout sheath will be perforated (by mechanical, explosive, or hydro-jetting) or milled out above the injection zone (if penetrated), at the base of the shallow freshwater zone, and above the formation underlying the injection zone (if penetrated), and cement will be squeezed into the perforations or milled-out window to form isolation plugs. The intervals below, between, and above the isolation plugs will also be filled with cement.

If the casing diameter is too small ( $<2.5$ in.), the well will be cemented up to the base of the shallow freshwater zone, and then the casing and annular grout seal above the cement plug will be removed using washover or milling techniques. The newly formed openhole interval created by washover or milling will be filled with cement.

This general approach was used to develop more detailed P\&A descriptions for the 21 WAG 10 NHF wells according to the unique characteristics of each well. The refined approaches were then used to develop generated waste volume and cost estimates. 


\section{INTRODUCTION}

The Oak Ridge National Laboratory (ORNL) in Oak Ridge, Tennessee, is operated for the U.S. Department of Energy (DOE) by Lockheed Martin Energy Systems (Energy Systems). ORNL has pioneered waste disposal technologies since World War II as part of its DOE mission. In the late 1950s, at the request of the National Academy of Sciences, efforts were made to develop a permanent disposal alternative to the surface impoundments and tanks at ORNL.

One such technology, the hydrofracture process, involved inducing fractures in a geologic host formation (a low-permeability shale) at depths of up to $1100 \mathrm{ft}$ and injecting a radioactive grout slurry containing low-level liquid or tank sludge waste, cement, and other additives at an injection pressure of 2000 to $8500 \mathrm{psi}$. The objective of the effort was to develop a grout that could be injected as a slurry and would solidify after injection, thereby entombing the radioisotopes contained in the low-level liquid or tank sludge waste. Four sites at ORNL were used: two experimental (HF-1 and HF-2); one developmental, later converted to batch process [Old Hydrofracture Facility (HF-3)]; and one production facility [New Hydrofracture Facility $(\mathrm{HF}-4)$ ].

This report is a continuation of the hydrofracture site evaluation efforts within Waste Areas Grouping (WAG) 10. It addresses 21 inactive wells associated with the NHF and makes recommendations for closing the wells. Reports that address 25 inactive wells associated with the Old Hydrofracture Facility (OHF) recommend closing those wells (plug and abandon) (BNI 1995b, 1995c, 1996). To date, 46 wells have been evaluated at the OHF and NHF sites.

The scope of this site evaluation was to conduct the following:

- access, sample, geophysically log, and evaluate observation, rock cover, and deep monitoring wells; and

- develop and evaluate permanent closure options (P\&A) for inactive wells associated with NHF.

These inactive wells are not presently used for injection/disposal, data collection, or monitoring operations but have not been permanently closed or modified for reuse. Some of the wells present a risk of contamination to the shallow groundwater system via annular or intrawell flow of grout filtrate or formation fluids. Well closure or modification options, which depend on the severity of the contaminant migration potential in the inactive wells, include the following:

- P\&A - placement of cement (or mechanical) plugs and/or a cement column in a well to seal the wellbore against fluid migration and protect the shallow freshwater zone (upper Maryville Limestone) from contamination;

- temporary monitoring-recompletion/modification as a temporary measure that allows for collection of data until the well is no longer needed for monitoring; and

- no action-a long-term option that involves continual, scheduled wellhead maintenance and security.

No long-term future use is expected to be identified for the inactive wells at NHF, so they should ultimately undergo P\&A. The P\&A activities are separate from and should generally precede any groundwater remedial cleanup or monitoring activities. 
Administratively, the 21 inactive wells, which are components of WAG 10, are the group for P\&A; others are expected to undergo characterization and P\&A evaluation in the future. None of the original injection wells are included in this group-only observation, rock cover, and deep monitoring wells.

\subsection{HYDROFRACTURE OPERATIONS}

The hydrofracture waste emplacement process involved injecting intermediate level liquid and tank sludge solid radioactive waste materials mixed with grout and additives under pumping pressures of 2000 psi or greater into a low-permeability shale formation (Pumpkin Valley Shale). The injected slurry spread along induced fractures (primarily bedding plane fractures) for several hundred feet from the injection wells, forming multiple, thin grout sheets (e.g., often less than $1 / 8$ in. thick). The hydrofracture waste disposal process resulted in emplacement of approximately $50,000 \mathrm{yd}^{3}$ (10.1 million gal) of radioactive wastes and grout containing an aggregate of approximately 1.4 million $\mathrm{Ci}$ of radioactivity over 25 years (1959-84).

Four different sites at ORNL were used in the experimental/developmental and full-scale application of hydrofracture operations:

- Hydrofracture Experiment Site 1 (HF-1, also known as the 4- acre site),

- Hydrofracture Experiment Site 2 (HF-2),

- Old Hydrofracture Facility (HF-3), and

- New Hydrofracture Facility (HF-4).

Figure 1.1 shows the locations of the DOE Oak Ridge Reservation (ORR), ORNL, and the four hydrofracture sites.

Three test injections, one at HF-1 and two at HF-2, introduced less than $100 \mathrm{Ci}$ of cesium-137 and short-half-life radionuclides into the upper Pumpkin Valley Shale. OHF (HF-3) was a developmental operation that was later converted into an operational facility, and NHF (HF-4) was designed as an operational facility. These two facilities were in operation for over 20 years. Table 1.1 summarizes the number of injections, the waste and grout volumes, and the primary radionuclide waste constituents.

Grout used as the carrier to entrain the liquid and solid radioactive wastes consisted of a mixture of portland cement, fly ash, clays, and a small amount of a set-retarding material. The portland cement acted as a binder in the grout matrix. Fly ash was added to reduce the amount of portland cement needed and thus reduce the cost of the mix; an additional benefit of using fly ash was a potential reduction in the strontium leach rate, the major radionuclide in the NHF waste. Clays (attapulgite, grundite, and illite) retarded and decreased the amount of phase separation water (grout filtrate) released by the mix and reduced the leaching potential of cesium (held by ion exchange). The set retardant (glucono delta lactone) increased the time the grout remained liquid and pumpable. The set retarder was used at OHF but was deleted from the mix used at NHF. 


\subsection{PROGRAMMATIC SETTING}

Remedial activities for ORNL's contaminated sites began in 1985 under the direction of the Remedial Action Program, later superseded by the Environmental Restoration (ER) Program, with activities in four areas (Energy Systems 1993c):

- assessment of the nature and extent of environmental contamination;

- remediation of inactive waste sites with the potential for releasing contaminants;

- decontamination and decommissioning (D\&D) to clean up surplus facilities; and

- research, development, and demonstration to apply to new restoration technologies.

Many ER activities are carried out under the auspices of the Federal Facility Agreement (FFA) for the ORR (FFA 1991) among DOE, the U.S. Environmental Protection Agency (EPA), and the Tennessee Department of Environment and Conservation (TDEC). The FFA, which became effective on January 1, 1992, formalized a procedural framework for developing, implementing, and monitoring appropriate response actions in accordance with the Comprehensive Environmental Response, Compensation, and Liability Act (CERCLA), the National Contingency Plan, the Resource Conservation and Recovery Act (RCRA), the National Environmental Policy Act (NEPA), Tennessee State law, and appropriate guidance and policy.

The strategy for remediation developed for ORNL in response to regulatory requirements has been oriented toward WAGs rather than individual sites because of the many contaminated sites and hydrologic complexity. Each WAG is the subject of separate planning and implementation. WAG 10 is defined as the underground components (i.e., wells, injected grout sheets, and contaminated deep groundwater) of the four hydrofracture sites. Other areas encompass surface or near-surface waste disposal units and contaminated media associated with the hydrofracture sites; for example, HF-1 lies within the boundaries of WAG 7, HF-2 within WAG 8, and OHF and NHF within WAG 5.

\subsection{PREVIOUS WORK AND DOCUMENTATION}

The last hydrofracture waste injection was conducted at NHF in January 1984. Operations were then shut down because of more stringent standards for injection well construction specifications. In $1985, \mathrm{DOE}$ decided not to seek a permit for future injections. Contributing to this decision was the issuance of underground injection control (UIC) regulations by TDEC (then known as the Tennessee Department of Health and Environment) and EPA.

In April 1986, EPA established its authority to enforce regulatory requirements for ORNL remedial response activities under RCRA Section 3004(u). In this new regulatory setting, EPA and the State of Tennessee directed ORNL to develop a closure plan for the injection wells and associated sites. This closure plan (Myrick and Stow 1987) outlined the scope of corrective actions needed to ensure adequate protection of groundwater resources in accordance with UIC and RCRA regulations. P\&A or other proper treatment of hydrofracture site wells was identified as the first step in a multistep closure process. 
In September 1986, Texas World Operations, Inc. (TWO) was awarded an ORNL contract to develop P\&A plans. ORNL identified 153 wells that penetrated the injection zone or were associated with the injection facilities and divided them into 2 groups for a phased development of P\&A plans (Switek and Stow 1986). ORNL designated 84 wells, generally those for which there was questionable or no future use, as Group I. TWO prepared 13 general closure plans for the Group I wells (TWO 1986), but these plans did not include specific recommendations on WM, health and safety (H\&S), quality assurance (QA), D\&D of equipment and materials, or site preparation. The remaining 69 Group II wells were not considered to be of high priority for P\&A at that time. Nevertheless, TWO made an initial assessment of P\&A options for Group II wells (TWO 1986).

In 1987, TWO completed a set of detailed P\&A plans (TWO 1987) for 11 of the Group I wells posing a potentially significant environmental risk with regard to the spread of contaminated groundwater at ORNL. These detailed plans include cost estimates and specific recommendations on a conceptual level for WM, H\&S, QA, D\&D, and site preparation.

The TWO procedures were based on a conservative and expensive approach to P\&A and WM which specified that all casing and annular grout be removed from the wellbores and that the waste thus generated undergo liquid-solid separation and waste stabilization in two specially constructed facilities. The TWO procedures were not used to procure P\&A contractor services because of remediation and funding reprioritizations.

Bechtel National, Inc. (BNI) prepared the Remedial Investigation Implementation Plan for ORNL WAG 10 (BNI 1988) based on a remedial investigation approach outlined by ORNL (1987). The implementation plan underwent two revisions: Revision 1 (BNI 1990) was issued in March 1990, and Revision 2 (BNI 1992) was issued soon after the FFA became effective. This second revision did not address the entire implementation plan, only the field sampling plan (FSP). The revised FSP incorporated the "observational approach" adopted by DOE for use in the remedial investigation/feasibility study (RI/FS) process and EPA's comments on Revision 1.

The preface to the revised FSP outlines a strategy for a time-phased remediation of the three WAG 10 operable units (OUs) (BNI 1992) that assigns OU3 (wells and boreholes) the highest priority for study and remediation because of the higher potential for exposure to humans and the near-surface environment and the greater feasibility of remediation alternatives. This phased approach was first developed in a February 13, 1992, working group meeting attended by DOE, TDEC, Energy Systems, and ER subcontractors.

P\&A plans exist for shallow wells at WAG 6 (Stansfield and Huff 1992), for ORNL wells in areas other than WAG 6 and the hydrofracture sites (Stansfield et al. 1992), and the OHF wells (BNI 1995c). Almost all wells covered by these plans, with the exception of those at hydrofracture sites, are shallow (i.e., less than $200 \mathrm{ft}$ deep). The plans were developed in response to a Tiger Team Audit, which noted that many unneeded wells at ORNL had not been decommissioned (plugged and abandoned). 


\subsection{SITE EVALUATION AND WELL P\&A OBJECTIVES}

The objectives of the NHF remedial site evaluation and P\&A options analysis report are taken from the screening-level risk assessment and the strategy/technical approach for hydrofracture wells and boreholes in the FSP for WAG 10 (BNI 1992). The site investigation of hydrofracture-associated wells within WAG 10 was designed to:

- facilitate an early action by determining the applicability and necessity of the response actions/technologies identified in the FSP,

- collect sufficient data to design and implement the selected action/technology, and

- gather hydrogeologic characterization data for consideration in a subsequent (groundwater or Melton Valley groundwater) investigation.

The remedial action objectives for all WAG 10 wells and boreholes, according to the FSP, are to mitigate leaching of contaminants, stop potential transport of contaminants, and prevent unacceptable exposure to human health and the environment from contaminated materials. These objectives were developed to control, mitigate, or remove various risk elements identified in the screening-level risk assessment in the FSP. The elements identified are:

- a source risk from the leaching of contaminants from wells, some of which were contaminated during the injection process,

- a transport pathway risk from the potential passage of contaminants from one formation to another across open intervals of the wells and in areas where the well casing and cement do not provide an adequate barrier to flow, and

- an exposure risk to an intruder attempting to drink well water.

The general response actions or technologies identified in the FSP to mitigate or remove these risks were institutional controls and P\&A (or recompletion) of the wells and boreholes associated with hydrofracture operations. Institutional controls address only the exposure risk. Well P\&A would control transport and exposure risk, although the potential for worker exposure would temporarily increase during $\mathrm{P} \& \mathrm{~A}$ field operations. Recompletion to collect additional data would be done as a temporary measure before P\&A or in wells where none of the aforementioned risks exist. The representative alternatives were no action (a CERCLA requirement) and institutional controls plus a combination of well recompletion and P\&A. The focus of this investigation was to acquire information and provide well P\&A options or recompletion recommendations for NHF wells.

As stated in the FSP, the remedial site evaluation objectives were to:

- determine which wells are potential candidates for recompletion and which are candidates for P\&A,

- provide data to support the preliminary design of well recompletion and P\&A, and

- refine the conceptual model to support future groundwater monitoring and/or remedial activities.

To achieve these objectives, the following conditions were included in the investigation:

- accessing the wells using a pressure-conservative drilling apparatus to tap into the wellbore, control any flow of contaminants from the well, reduce risk to workers and in general, protect human health and the environment; 
- sampling and analyses of the water in the wellbore for the analytes listed in Table 1.2 to determine and establish the

- appropriate protection for workers at the well,

- probable near-well groundwater composition,

- salinity (density) to help resolve the origin of the well water,

- sequence of wells to be logged (least-to-most contaminated), and

- characteristics of wastewater that would be generated during future recompletion or plugging of the well(s);

- recording any pressure in the wells;

- geophysically logging the well(s) to extract construction information and evaluate current integrity of any barriers to flow, evidence of flow within/outside the wellbore [i.e., temperature, salinity anomalies (resistivity), etc.], and verification of lithologic horizons;

- developing conceptual model(s) of potential transport pathways for each well from the existing historical and current investigation data to support well P\&A design; and

- analyzing the well condition(s) to rank the wells for early action based on contamination, migration potential (artesian conditions), and external mechanical well integrity to determine suitable procedures for P\&A.

ORNL, EPA, and TDEC concluded that many of the existing inactive shallow wells (various WAGs) and deep wells (WAG 10) at the hydrofracture sites need closure (P\&A) to remove avenues for potential interaction of contaminants and receptors. This type of remedial action (P\&A) is well established for petroleum industry, liquid waste injection, geothermal, and brine recovery/disposal wells, but has not yet been applied to radioactive waste injection, monitoring, or observation wells. The operational techniques and materials that would be used for P\&A of the ORNL wells are standard practice, but the associated waste management and safety and health measures add significant complexity.

Specific objectives for P\&A are to:

- stop potential vertical transport of contaminants within wellbores

- protect the freshwater zone from contamination by residual radioactive grout filtrate, migration of high-salinity natural formation fluid (brine), and/or influx of surface water runoff;

- protect surface soil and surface water from contamination by radioactive grout filtrate and/or high-salinity formation fluid;

- isolate the injection/disposal horizon (Pumpkin Valley Shale);

- eliminate transport via contaminant leaching from wells and boreholes;

- prevent unacceptable exposure to human health and the environment from contaminated materials within the wellbores;

- minimize conflict with potential future surface land use; 
- minimize potential environmental impacts (e.g., fugitive dust emissions or storm water discharges) from well P\&A activities;

- minimize the amount of waste materials generated during P\&A; and

- capture the waste originating from well P\&A activities for disposal and/or treatment.

These objectives are based on environmental regulations, ORNL policies, and best management practices. This remedial site evaluation and well P\&A report develops closure options for the 21 WAG $10 \mathrm{NHF}$ wells and boreholes and evaluates those options, taking these objectives into account.

\subsection{REPORT ORGANIZATION AND SCOPE}

This report is the fourth in a series of documents that report on recent investigations conducted at WAG 10 (hydrofracture facilities wells and boreholes). The first three reports address wells associated with activities that were conducted at OHF (BNI 1995b, 1995c, and 1996). Twenty-five wells were evaluated in these reports. This report focuses on 21 wells and boreholes associated with waste grout injection activities conducted at NHF. To date, a total of 46 wells associated with hydrofracture operations previously conducted at ORNL have been investigated and evaluated. The original injection wells at both sites remain to be studied.

This report consists of two volumes:

- Volume I presents results of the NHF remedial site evaluation and makes recommendations for closure of the 21 NHF wells and/or usage for temporary site monitoring. The figures and tables included in this volume have been incorporated at the end of each chapter of the report.

- Volume 2 reports on the field activities conducted at NHF and contains summaries for each well. The well summaries present an interpretation, most of the well data, well construction details, and a recommendation for closure of the well. Each well summary is meant to "stand alone" as an aid for planning future activities related to a specific well. The figures and tables included in this volume have been incorporated at the end of each section of the report.

This project utilized screening-level radiological and chemical data analyzed for in primarily highly saline brine collected from unpurged wells. The authors, because of these data limitations, utilized all available historical data obtained from other sources in combination with the new data to assist in the interpretation.

Activities of various radionuclides are discussed throughout this report and when appropriate units are changed. Some readers may not be familiar with these units. Therefore, an explanation of some of the units used herein are included in Appendix A in Volume 2 of this report. Figure A.1 is included to present a perspective on radionuclide activities and half-life. 


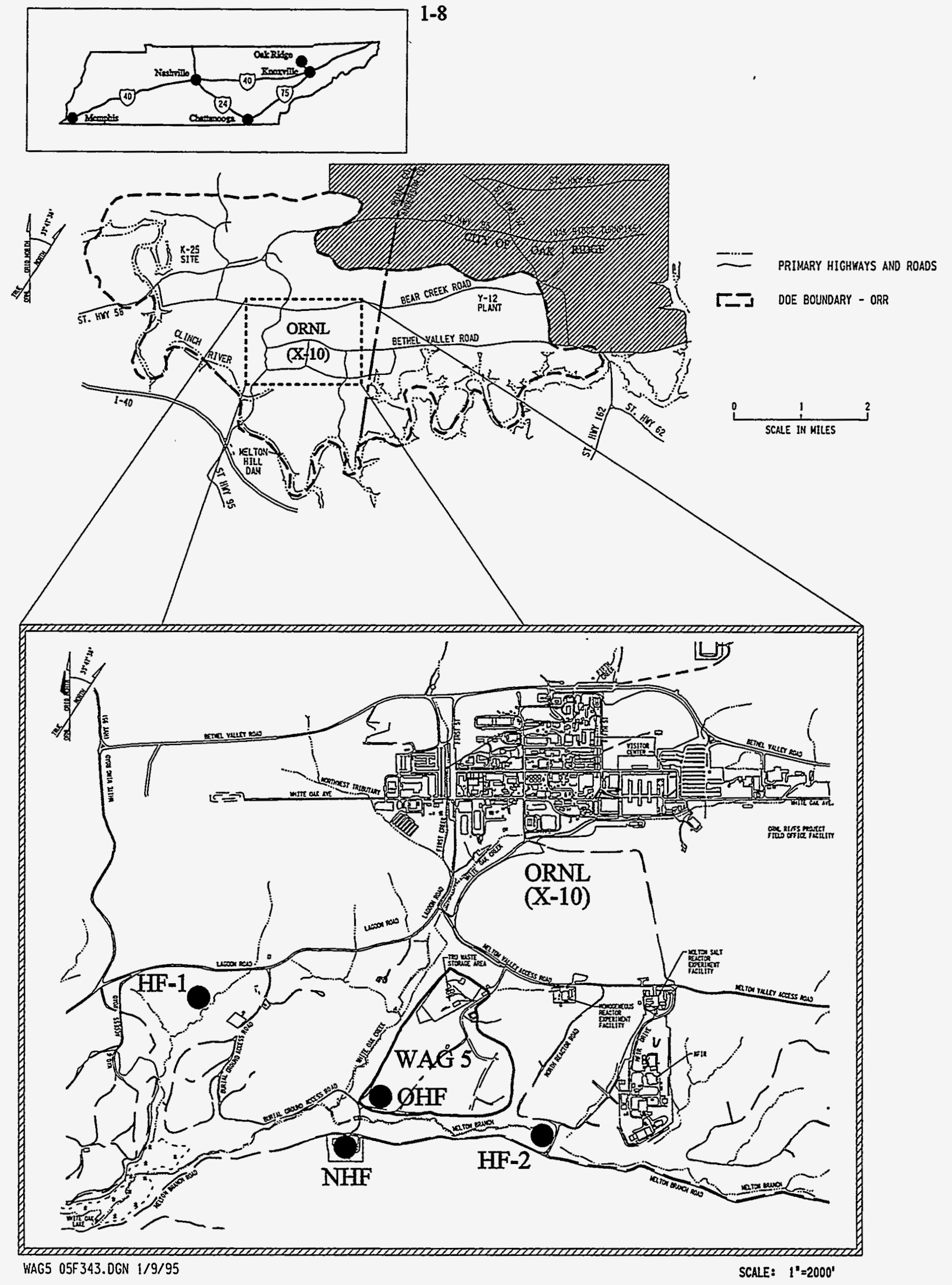

Fig. 1.1. Maps showing the Department of Energy Oak Ridge Reservation and four hydrofracture sites. 
Table 1.1. Summary of hydrofracture grout injections

\begin{tabular}{|c|c|c|c|c|c|c|c|c|c|c|c|}
\hline \multirow[b]{2}{*}{ Injection type } & \multirow{2}{*}{$\begin{array}{c}\text { Number of } \\
\text { injections }\end{array}$} & \multirow{2}{*}{$\begin{array}{l}\text { Injection } \\
\text { depth(ft) }\end{array}$} & \multirow{2}{*}{$\begin{array}{l}\text { Waste volume } e^{a} \\
\left(\operatorname{gal} \times 10^{3}\right)\end{array}$} & \multirow{2}{*}{$\begin{array}{c}\text { Waste Plus } \\
\text { Water volume } \\
\left(\text { gal } \times 10^{3}\right)\end{array}$} & \multirow{2}{*}{$\begin{array}{l}\text { Grout volume } \\
\left(\mathrm{gal} \times 10^{3}\right)\end{array}$} & \multicolumn{6}{|c|}{ Primary waste constituents ${ }^{b}$ (Ci) } \\
\hline & & & & & & $\mathrm{Sr}-90^{\circ}$ & Cs- $137^{c}$ & $\mathrm{Cm}-244^{d}$ & $\mathrm{TRU}^{e}$ & Other & Total \\
\hline 1114 & & & & & 1 & & & 1 & & & . \\
\hline Experimental (1959) & 1 & 290 & $N / A^{f}$ & N/A & 27 & & 35 & & & $\begin{array}{c}8.7 \\
(\mathrm{Ce}-141)\end{array}$ & 44 \\
\hline (in & & & 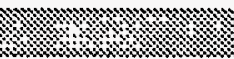 & & 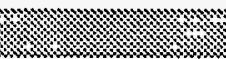 & & & & & - & \\
\hline Experimental (1960) & 2 & 934 and 694 & $\mathrm{~N} / \mathrm{A}$ & N/A & 224 & & 50 & & & & 50 \\
\hline (1) (1) & 器 & $\because$ & \% & (n) & (3) & $\approx$ & & & & & ? \\
\hline Experimental (1963-65) & 7 & 872 to 945 & 436 & 457 & 678 & 1,439 & 5,188 & N/A & N/A & N/A & 6,627 \\
\hline Operational (1966-79) & 18 & 784 to 872 & 1302 & 1,200 & 2,281 & 43,008 & 605,667 & 256 & $7^{e}$ & N/A & 648,938 \\
\hline (1) & ;. & & 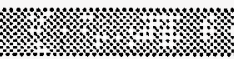 & \%... & \%. & 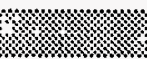 & 18 & & & ঋ. & « \\
\hline Experimental (1974) & 1 & 1090 & N/A & 66 & 98 & & & & & $\begin{array}{c}20 \\
\text { (Au-198) }\end{array}$ & 20 \\
\hline Operational (1982-84) & 13 & 990 to 1069 & 2,240 & 2,540 & 2,873 & 644,505 & 83,765 & 7,464 & 2,125 & 13,314 & 751,173 \\
\hline TOTAL $^{8}$ & 42 & & 3,978 & 4,263 & 6,181 & & & & & & $1.4 \times 10^{6}$ \\
\hline
\end{tabular}

Source: Modified from Myrick and Stow (1987). Grout injection depths from Weeren et al. (1974), Weeren (1984), and Haase and Stow (1988).

Note: a. Values are estimates of injected volumes only. Phase separation and bleedback volumes cannot be accurately determined for many of the injections.

b. Other radionuclides were present in waste in much smaller quantities, were in equilibrium with listed radionuclides, or were not analyzed before injection.

c. Fission product (fragment).

d. Transuranic listed as primary radionuclide.

e. TRU represents transuranic elements.

f. $\mathrm{N} / \mathrm{A}=$ not analyzed.

g. Totals here should be used with caution. Data on radionuclide content are not available for injections in this series. 
Table 1.2. Field measurements and Close Support Laboratory analytes

\begin{tabular}{ll}
\hline \multicolumn{1}{c}{ Field measurements } & \multicolumn{1}{c}{ Close Support Laboratory analytes } \\
\hline $\begin{array}{l}\mathrm{pH} \\
\mathrm{Eh} \\
\text { Temperature }\end{array}$ & $\begin{array}{l}\text { Gas chromatography (GC) (halogenated and double- } \\
\text { bonded volatile organic compounds) }\end{array}$ \\
Specific conductance & Anions \\
Alpha, beta-gamma screened w/field & Cations \\
instruments & Gross alpha \\
& Gross beta \\
& Tritium \\
& Gamma spectroscopy \\
& Strontium-90 \\
& Total alkalinity (CaCO \\
& Total suspended solids (TSS) \\
& Total dissolved solids (TDS) \\
\hline
\end{tabular}




\section{SITE OPERATIONAL HISTORY}

The history of hydrofracture waste injection operations, both experimental and production-type, at $\mathrm{HF}-1, \mathrm{HF}-2$, OHF (HF-3), and NHF (HF-4), has been previously summarized (BNI 1995c and 1996). More detailed reports are identified in the References chapter of this report. For consistency and comparison, a brief discussion of OHF activities followed by a more complete discussion of NHF activities is included in this section of the text.

OHF is located near the southwest comer of WAG 5 (Figs. 2.1 and 2.2). The new batch waste injection facility, NHF, is approximately $900 \mathrm{ft}$ south of OHF (Weeren et al. 1974, Weeren 1984f). The top of the injection horizon (Pumpkin Valley Shale) at NHF is approximately $200 \mathrm{ft}$ deeper than at the OHF facility. The stratigraphy of the two sites is similar.

OHF (HF-3) was constructed to inject intermediate level radioactive waste (ILW) in a grout carrier into the Pumpkin Valley Shale (injection horizon). The waste stream was alkaline, and ${ }^{137} \mathrm{Cs}$ was the dominant radionuclide (Weeren 1984f). A total of 25 separate injections were completed at the facility: 7 experimental and 18 production-type. In contrast to NHF, no tank sludge injections (SI) were made at OHF. Approximately $660,000 \mathrm{Ci}$ of activity, within a total of $23,256 \mathrm{yd}^{3}$ of waste and grout mixture, was injected at the site (Myrick and Stow 1987).

The NHF (HF-4) batch process plant was constructed in 1981 to blend and inject wastes from two streams: ILW (evaporator concentrate) and resuspended tank sludges (SD). The characteristics of the ILW were physically and chemically similar to that injected at $\mathrm{OHF}\left({ }^{137} \mathrm{Cs}\right.$, dominant radionuclide). The SI injections, however, were different in both physical and chemical characteristics, and dominant radionuclide $\left({ }^{90} \mathrm{Sr}\right)$ content (Table 2.1 and Fig. 2.3). The NHF plant was placed into operation in May 1982.

Two different methods for determining ideal mix ratio were used at NHF because of the differences in physical and chemical characteristics of the waste streams (ILW and SI) (Weeren 1984f). Table 2.2 shows the general makeup of the dry solids composition. The mix ratio used for the ILW injections was determined in a similar fashion as that used at OHF. A "mock" nonradioactive solution with a chemical composition similar to the waste was tested and the optimum mix ratio was determined for a specific injection (Table 2.3). The mix ratio used for the sludge injections was determined based on physical (apparent viscosity) properties of the resuspended sludge, rather than its chemical properties. A maximum and minimum range of mix ratio was set for the individual SI injection.

Maintaining the mix ratio during waste injection was critical to entombment of the waste in the injection horizon. Excessive contaminated grout filtrate would be expected when the solids content is lower than specified for the injection. The "rule" established for the injections was to maintain the ratio to within $\pm 10 \%$ of the desired ratio for the $I L W$ injections and within the ratio for the SI injections. The actual mix ratios used are discussed in a later section of this report.

A site proof test injection was conducted in June 1973 (prior to NHF plant construction) (Weeren et al. 1974). A total of $483 \mathrm{yd}^{3}$ (97,643 gal) of grout containing $20 \mathrm{Ci}$ of Au-198 was injected at a depth of approximately $1,090 \mathrm{ft}$. The formation fractured at a pressure of $2,650 \mathrm{psi}$. Following the site proof test and plant construction, 13 production-type injections (June 1982 through January 1984) were completed at the facility: $3 \mathrm{IWW}$ and $10 \mathrm{SI}$ injections. Each injection was initiated with water to fracture the formation and followed by water to clean and wash out the 
injection system. The formation fractured at 2,500 psi for injection SI-5 and 8,500 psi for injection SI-2. These were the minimum and maximum formation breakdown pressures needed to emplace the waste. Approximately $750,000 \mathrm{Ci}$ of activity was injected at the NHF site (Table 2.4), within 25,294 $\mathrm{yd}^{3}$ (5.1 million gal) of waste and grout.

After the fourth injection (SI-3), a major problem with the injection well was discovered (December 1982): the tubing string had been cemented into the well casing (Weeren et al. 1984g). The cause of failure was determined to be contaminated grout leakage into the annular region between the central tubing and well casing through "holes" at tubing couplings. The primary factors that contributed to failure were use of a tubing string with a less effective joint design, the lack of QA in makeup of the tubing string, and excessive deviation from vertical of the original injection well.

Well recovery operations began immediately and were completed in March of 1983 . Numerous problems encountered during the well recovery operations are documented in detail in Weeren et al. (1984g). Figure 2.4 presents the final reconfigured NHF injection well, taken from Weeren et al. 1984. The injection well was placed back into operation in April 1983 prior to injection SI-4. The final injection (ILW-21) was complete in late January 1984. After this injection, the open slot was plugged and the well was shut in. No waste injection activity has taken place at the facility since that time.

Two types of wells (rock cover [monitoring] and observation) were installed between 1973 and 1980 to monitor operations at NHF (Table 2.5) (Weeren et al. 1974, Weeren 1984g). The rock cover wells were used for two purposes during NHF operations: pressure and "permeability" monitoring (Tables 2.6 and 2.7). The design of the rock cover wells was standardized and they were constructed in similar fashion. A network of eight rock cover wells was installed at locations in a $45^{\circ}$ degree arc starting at ORNL grid north (Well 1971) from the injection well. The radial distance from the injection well varied from approximately 190 to $340 \mathrm{ft}$. Each well has 4-in.-ID carbon steel casing set to a depth of 400 to $600 \mathrm{ft}$, and all of the wells have an approximate 100-ft openhole interval. The openhole intervals are in the Rogersville Shale and/or Rutledge Limestone (formations overlying the injection horizon). There are no reports that the groundwater in these wells was sampled and analyzed to provide a baseline prior to initiation of NHF operations.

The rock cover wells were topped off with fresh water for pressure monitoring over the time of injections. A pressure gauge on the wellhead then monitored the impact of the injection pressure and verified the probable position/orientation of the injected grout. Pressures measured at the rock cover wells were compiled based on Weeren (1984a through $\mathrm{f}$ ) and Tiegs (1983a through e, 1984a through c). It appears that the wells were shut in between injections except for periods of water acceptance testing ("permeability"), wellhead maintenance, and wellhead equipment failure.

Six observation wells were installed between 1973 and 1980 to monitor the position, depth, and location of the grout sheets within the injection horizon (Table 2.5). These particular wells are cased with 2.88-in.-ID carbon steel casing (except for Well 1970, which has nonstandard 1.25-in.-ID tubing) to total depth (ft). Some of the observation wells were installed with low-strength grout (polymeric water-based gel) in the bottom $350 \mathrm{ft}$ of the borehole in an attempt to prevent casing pullapart caused by grout sheet uplift. The observation wells were designed to allow passive borehole gamma ray logs (small-diameter logging sonde, measured in mrem/h) to be run to sequentially identify the grout sheets without providing a conduit to the surface for the contaminated grout or filtrate. One of the wells (well 1972), located north of NHF, intercepted OHF grout sheets during drilling. 
Gamma logs were run in the wells at OHF following the initial injection at NHF. No evidence of NHF grout sheets extending into the OHF area was found. There is no record of the water in the observation wells having been sampled and analyzed to provide a baseline prior to initiation of injections at NHF.

After the tenth injection (SI-8), benchmarks were established in the area around NHF to monitor the uplift pattern(s) caused by grout emplacement (Fig. 2.5). Approximately 1 in. $(25 \mathrm{~mm})$ of maximum uplift was measured within $200 \mathrm{ft}$ of the injection well. The uplift data seem to indicate that the grout slurry migrated preferentially, updip to the north (Haase and Stow 1987). This pattern would be expected based on what is known of subsurface geology: the slurry should migrate updip in the direction of least lithostatic pressure.

In 1984, following the last injection, three deep monitoring (DM) wells were installed in the vicinity of NHF to provide information on the hydrologic conditions of the injection interval (Pumpkin Valley Shale) (Haase 1987). The wells are positioned approximately $1000 \mathrm{ft}$ radially from the injection well: 2373 (DM-1) to the east, 2374 (DM-2) to the west, and 2375 (DM-3A) to the north. Geologically, wells 2373 and 2374 are generally along strike, and 2375 is updip from the injection well. No grout sheets were penetrated by any of these wells. The wells were installed with long openhole intervals $(\approx 1,000 \mathrm{ft}$ ) spanning several formations. Well construction details can be found in Geraghty\&Miller, Inc. (1986).

Sampling events were conducted in these wells in September 1984 and January 1985 (Haase et al. 1987). Analytical results indicated that water in DM wells 2373 and 2374 is contaminated with radionuclides: ${ }^{90} \mathrm{Sr},{ }^{137} \mathrm{Cs},{ }^{60} \mathrm{Co},{ }^{3} \mathrm{H}$, and traces of ${ }^{106} \mathrm{Ru}$ (short lived). The water samples also contain elevated concentrations of nitrate. Well 2375, updip of the injection well, was found to contain low levels of contamination: low concentrations of ${ }^{90} \mathrm{Sr}$ and ${ }^{137} \mathrm{Cs}$, and no detectable nitrate.

The source of the contamination discovered in wells 2373 and 2374 is filtrate originating from grout injected at NHF. The two primary tags that tie the contamination to grout filtrate are ${ }^{106} \mathrm{Ru}$ and nitrate (from $\mathrm{NaNO}_{3}$ in the source waste). Ruthenium106 was reported in injections ILW-19 and SI-2. The results suggest that some aqueous radionuclides, sourced from the injections, have migrated some distance $(>1,000 \mathrm{ft})$ from the solidified grout sheets.

After discovery of radiological contamination in wells 2373 and 2374, four new DM wells were installed [2952 (DM1-RT), 2953 (DM3-RT), 2954 (DM1-PV), and 2955 (DM2-PV)]; the three original DM wells $(2373,2374$, and 2375 ) were also reconfigured. Work on these wells was completed in January 1986. The primary objectives for installation of these wells were to allow for the acquisition of groundwater samples from specific formations and gain hydrologic information on the formations. Well cluster 2373, 2952, and 2954 is located to the east and cluster 2374 and 2955 is located to the west of the injection well. Well construction details can be found in Geraghty\&Miller, Inc. (1986).

In the summer of 1985 , a TVA geophysical logging crew and their equipment were contaminated at Well 2954 (DM1-PV). Radiological contamination was not suspected or expected by the geophysical logging crew at the time because the well was uncapped and flowing artesian. After this incident, the well was capped.

In January 1986, a second incident occurred at the same well. An ORNL sampling team was spattered with radionuclide-contaminated liquids that spewed out of Well 2954 (DM1-PV) after it was opened (uncapped). The sampling team did not expect the well to be pressurized when the attempt to sample was made at this location. 
The groundwater in the new and reconfigured DM wells was sampled in January 1986 (Haase et al. 1987). The results of this sampling confirm radiological contamination in the injection horizon and suggest the possibility of contamination in the underlying Rome Formation. Traces of radiological contaminants were also discovered in the overlying Rutledge Limestone. The authors suggest that radiological contamination in the Rutledge Limestone may indicate minor upward migration of contaminated groundwater. 


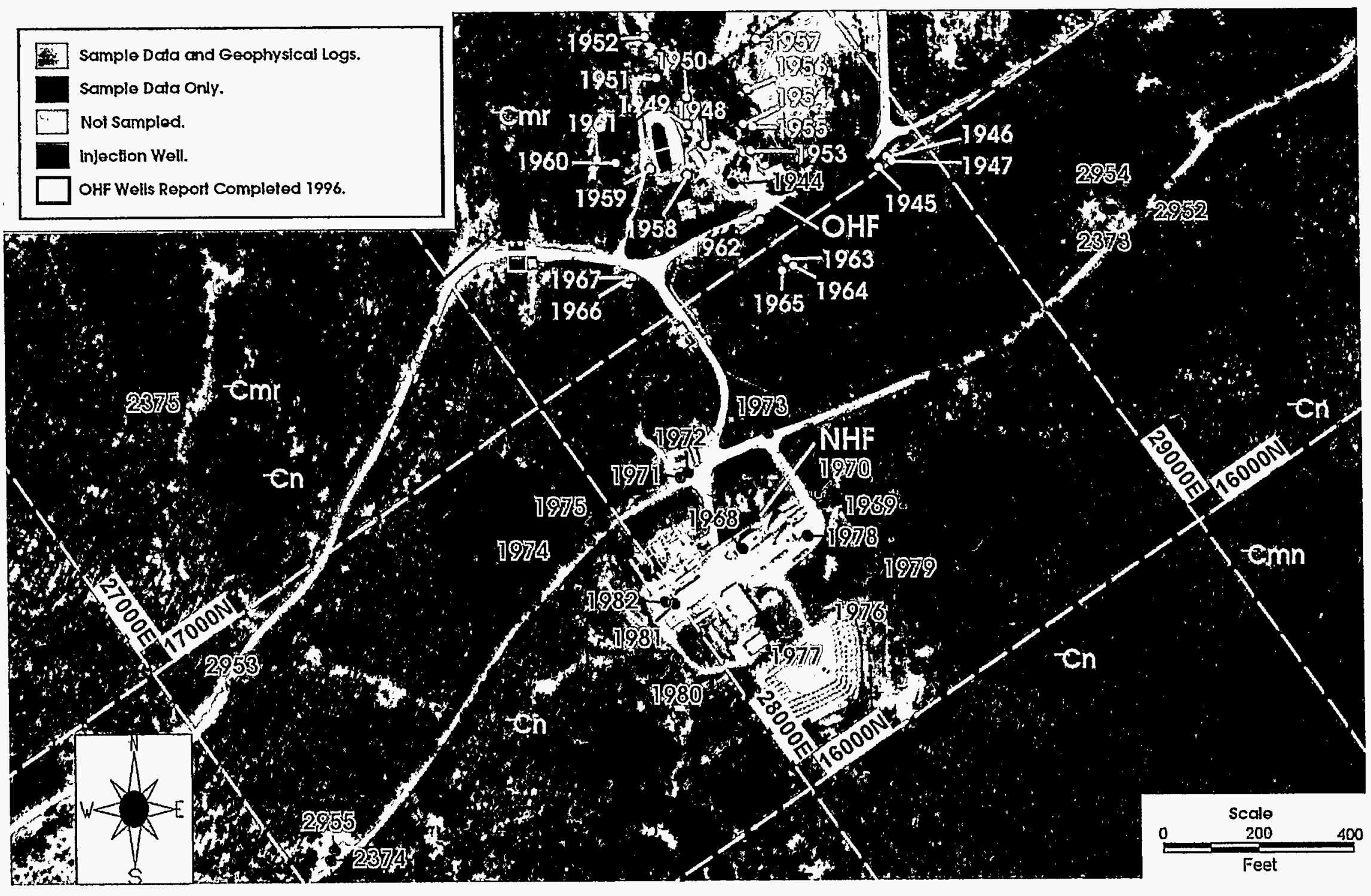

Fig. 2.1. Aerial view of hydrofracture operations and related wells. 



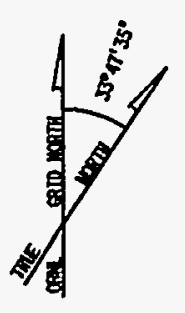

2-6

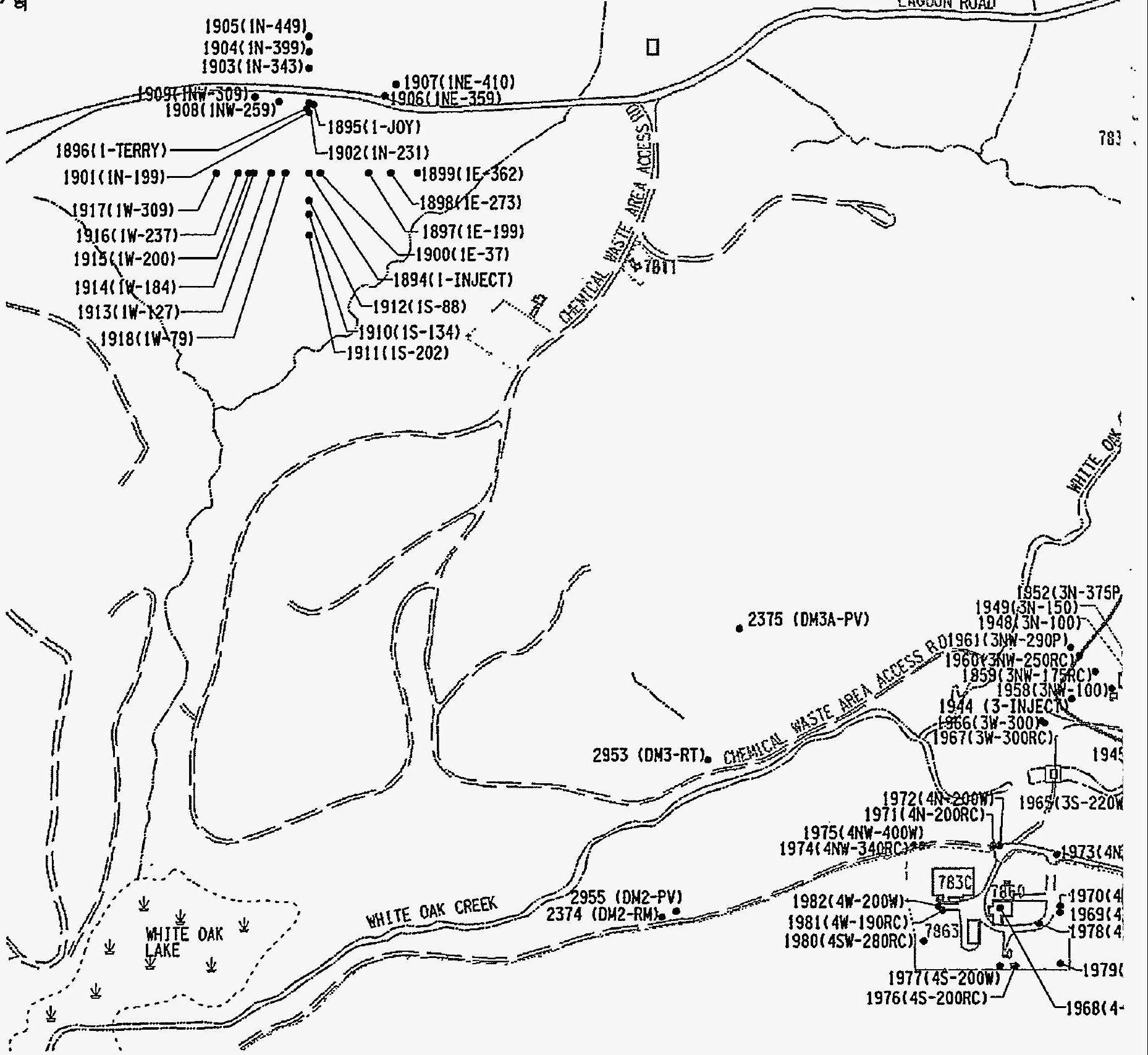




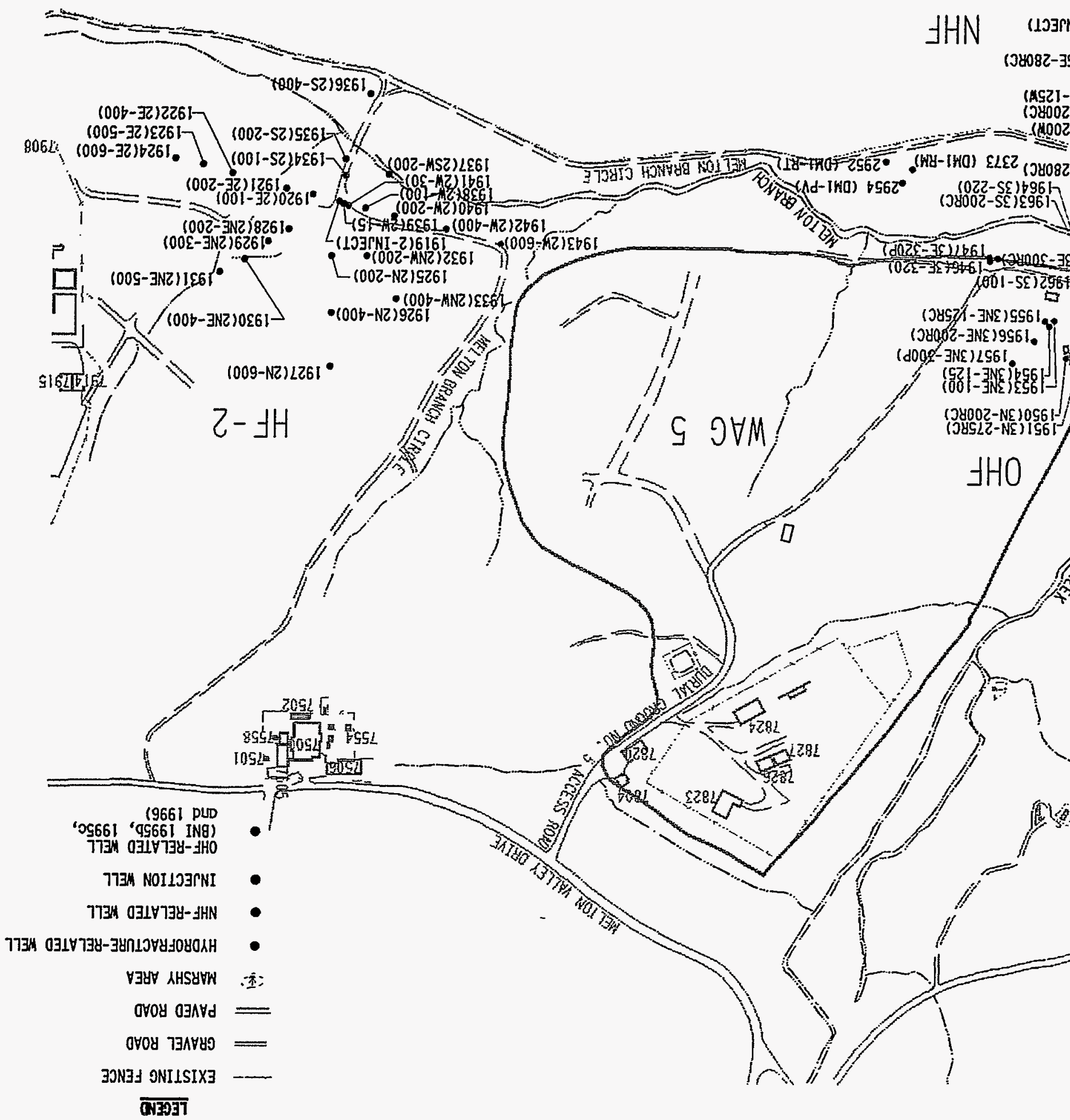




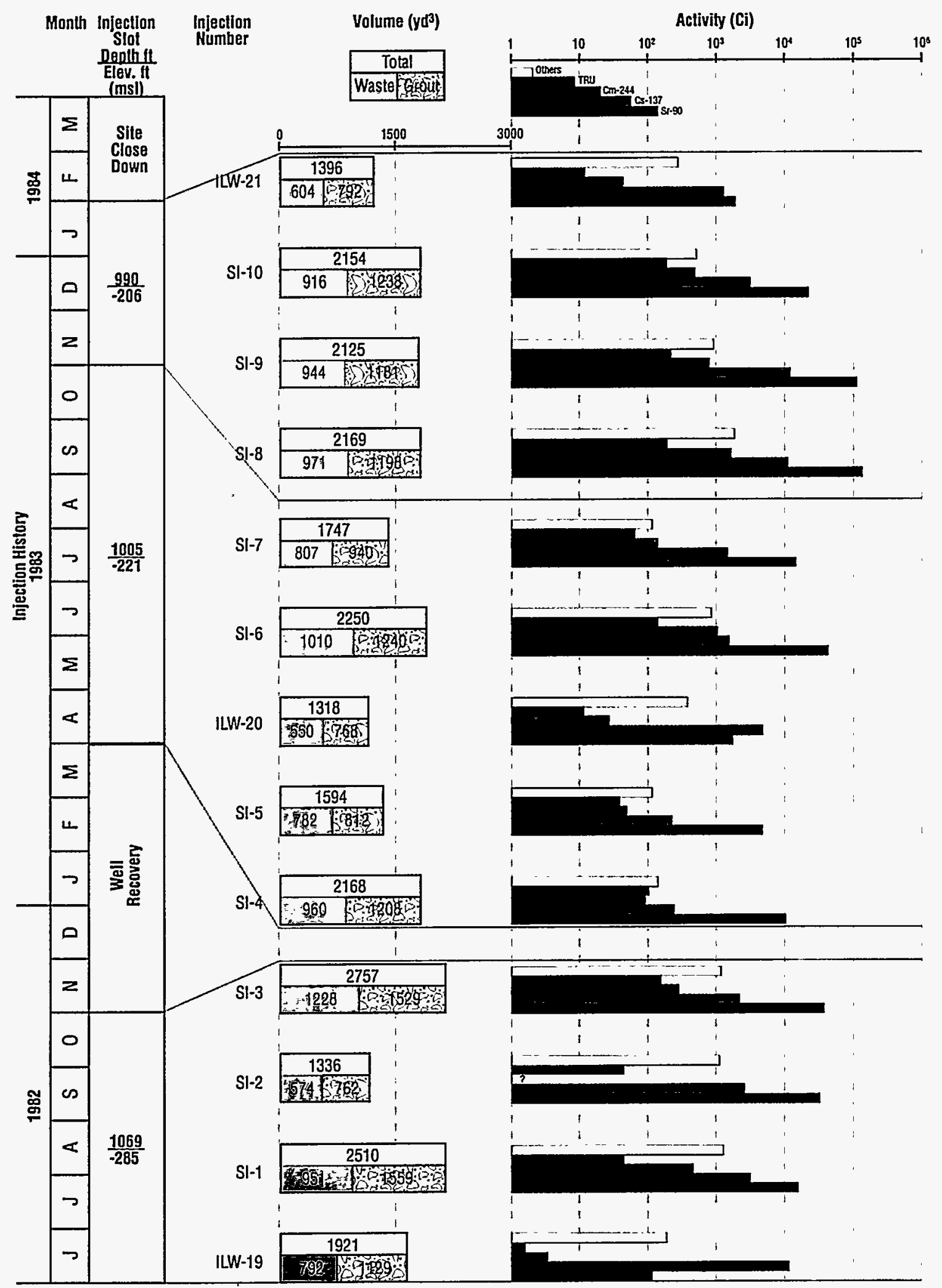

Fig. 2.3. Summary of volume and activities injected at New Hydrofracture Facility. 


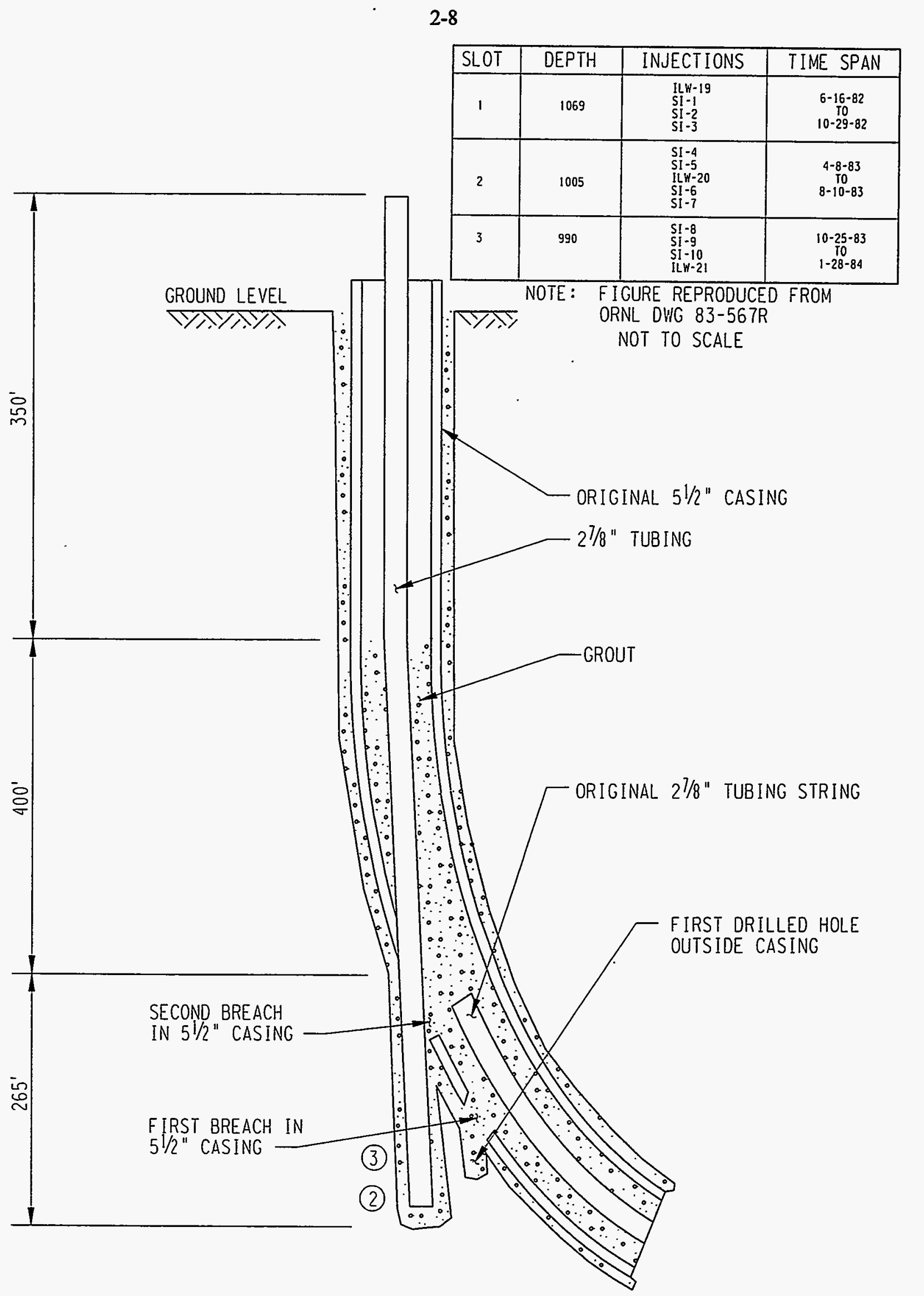

Fig. 2.4. Final configuration of the New Hydrofracture Facility injection well. 

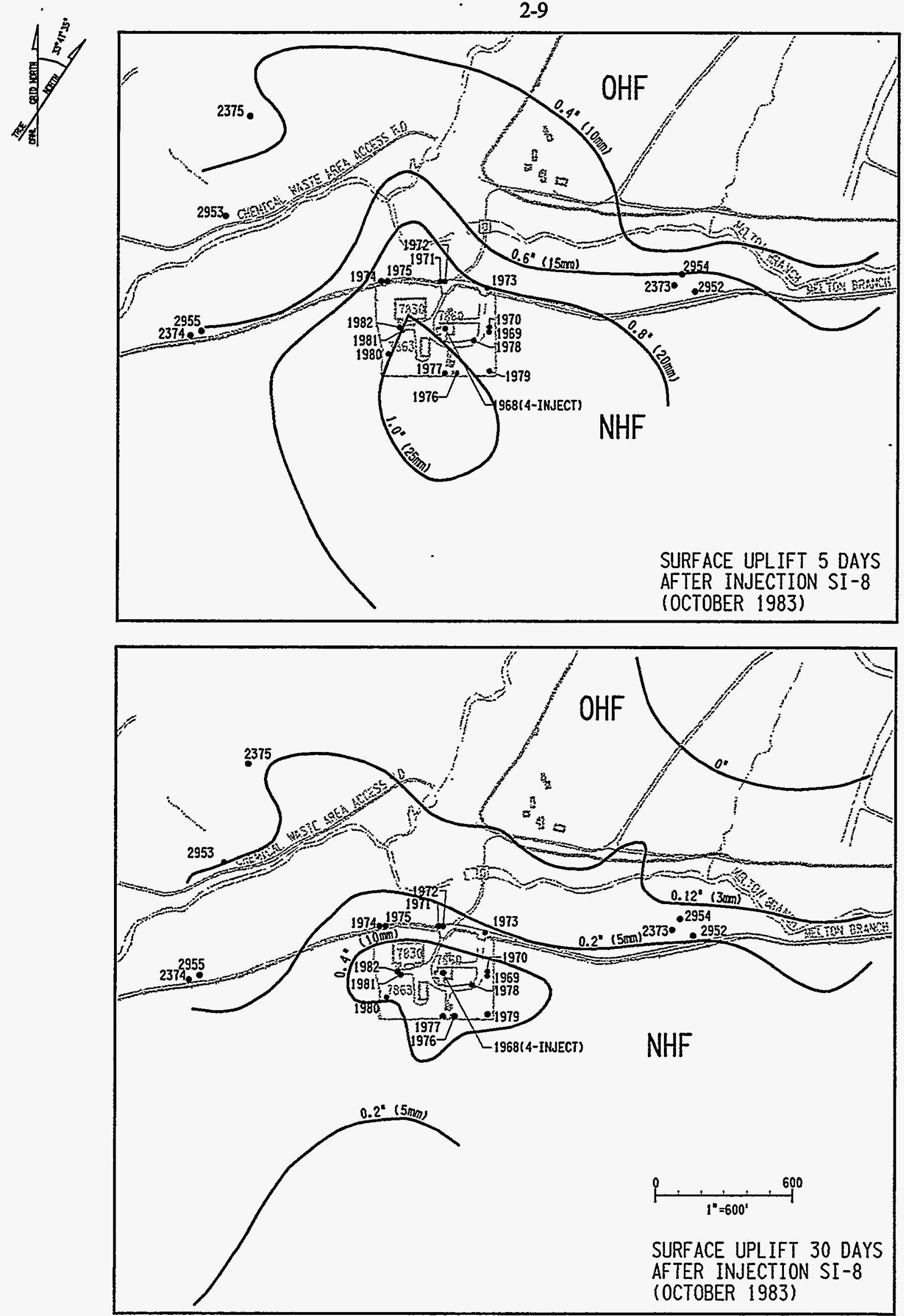

MODIFIED FROM: HAASE AND STOW 1989

Fig. 2.5. Ground surface uplift at the New Hydrofracture Facility.: 
Table 2.1. Radionuclide content of waste injections conducted at the New Hydrofracture Facility

\begin{tabular}{|c|c|c|c|c|c|c|c|c|c|c|c|c|c|c|c|}
\hline \multirow[b]{2}{*}{ Tank } & \multicolumn{3}{|c|}{ Primary Radionuclldes (C) } & \multicolumn{6}{|c|}{ Miscellaneous Radionuclides (Ci) } & \multicolumn{6}{|c|}{ Transuranics $(\mathrm{CD})$} \\
\hline & Sr-90" & Cs-137" & $\operatorname{Cn} 2-244^{b}$ & $\mathrm{Co}-60^{\mathrm{C}}$ & $\mathrm{Ru}-106^{n}$ & $\mathrm{Cs}-134^{n}$ & Eu-152" & Eu-154" & Eu-155" & U-233 & $\mathrm{U}-235^{d}$ & $\mathbf{U}-238^{d}$ & Pu-239 & Pu-238 & $A \mathrm{~m}-241$ \\
\hline \multicolumn{4}{|c|}{ Hofotinow } & 聯 & & & 隹 & \% & m & $1 \%$ & ঋ & & 哽 & & \\
\hline W-24 & 71 & 4414 & 3.2 & 18 & 27 & 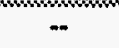 & $\cdots$ & - & - & - & - & - & 0.2 & - & 0.7 \\
\hline$W-25$ & 27 & 4964 & 0.4 & 13 & 1 & -- & - & -- & -- & - & - & - & nil & 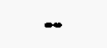 & 0.1 \\
\hline W-26 & 22 & 2922 & 0.2 & 8 & 113 & - & - & .- & -. & - & -. & - & - & - & 0.4 \\
\hline W-27 & 18 & 3526 & 0.1 & 10 & 125 & -. & -. & -. & -. & -- & -- & -- & -- & - & 0.2 \\
\hline W-29 & 18 & 1507 & 1.1 & 4 & 28 & .. & .. & .. & $\ldots$ & - & $\ldots$ & .. & nil & 0.1 & 0.1 \\
\hline \multicolumn{4}{|c|}{ Hor ron } & \% & $\%$ & & 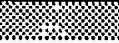 & \% & 䋛 & 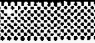 & & 聯 & \% & & $\%$ \\
\hline W-24 & 7800 & 2000 & 350 & 700 & $-h$ & -. & 240 & 190 & 54 & - & .. & - & 9.3 & 16 & 15 \\
\hline W-25 & 7900 & 1700 & 270 & 460 & -. & -. & 150 & 150 & 38 & - & - & - & 5.7 & 8.9 & 19 \\
\hline W-26 & 2600 & 1200 & 57 & 33 & - & - & 35 & 32 & 9.5 & - & - & -. & 0.42 & 0.85 & 5.1 \\
\hline W-27 & 11000 & 790 & 99 & 0.7 & -- & - & 31 & 28 & 8.8 & - & -- & - & 1.1 & 2.4 & 6.2 \\
\hline W-28 & 5.2 & 430 & 0.33 & 1 & -- & - & - & - & -- & - & - & - & 0.0051 & 0.019 & 0.3 \\
\hline$W-29$ & 5.9 & 480 & 0.37 & 1.2 & - & -. & -. & -- & $-\cdot$ & $\cdots$ & $\cdots$ & .. & 0.0058 & 0.022 & 0.034 \\
\hline W-30 & 7400 & 220 & 28 & 1.8 & -- & -. & 13 & 13 & 3.1 & - & - & - & 0.18 & 0.33 & 3 \\
\hline \multicolumn{4}{|c|}{ Whofol } & 检 & 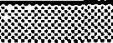 & & 1 & 伭 & & 1 & $\%$ & \% & & \% & \\
\hline $\mathrm{W}-24$ & 8175 & 1431 & -- & 204 & - & 9 & 15 & 11 & 2 & 28.2 & - & $\because$ & 2.6 & 3.3 & -- \\
\hline$W-25$ & 532 & 114 & -. & 9 & - & 1 & 1 & 1 & 1 & 1.7 & - & -- & 0.1 & 0.2 & -. \\
\hline$W-26^{e}$ & 15488 & 885 & - & 415 & 30 & 6 & 6 & 6 & 2 & 7.9 & - & -. & 12.1 & 4.5 & - \\
\hline W-27 & 22163 & 208 & - & 192 & - & .- & 33 & 33 & 12 & 32.7 & .. & .. & 14.7 & 26.5 & -. \\
\hline \multicolumn{4}{|c|}{ (n) } & & & 8 & $x$ & \% & & xx & & \% & $\%$ & & 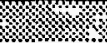 \\
\hline W-24 & 13402 & 176 & 93.7 & 141 & - & 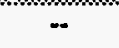 & 42 & 33 & 14 & - & - & - & 14.8 & 7.1 & 29.7 \\
\hline$W-25 A^{8}$ & 6905 & 1600 & 154.4 & 392 & - & 7 & 99 & 89 & 29 & 19 &.- & -- & 6.3 & 9.4 & 7.7 \\
\hline W-25B & 4292 & 337 & 45 & 95 & -- & 1 & 23 & 25 & 9 & 4.1 & -. & - & 14.6 & 6.1 & 12.5 \\
\hline W-25C & 1569 & 124 & 16.5 & 35 & -- & 1 & 9 & 9 & 3 & 1.5 & -. & .- & 5.4 & 2.2 & 4.6 \\
\hline W-26A & 13367 & 272 & 47.1 & 55 & -. & -. & 17 & 33 & 15 & 3.5 & .. &. & 35.9 & 15 & 45.7 \\
\hline$W-26 B$ & 5075 & 112 & 15.4 & 23 & $\cdots$ & -. & 4 & 11 & 4 & 1.7 & .- & .. & 21 & 7.3 & 18.9 \\
\hline W-27A & 5282 & 49 & 1 & 20 & -. & -- & - & -. & -. & - & .- & -. & 1.4 & 1.2 & 0.7 \\
\hline W-27B & 5078 & 48 & 1 & 19 & - & - & - & -- & - & -- & -- & - & 1.6 & 1.1 & 0.7 \\
\hline W-30A & 5055 & 1171 & 113 & 287 & - & 5 & 72 & 65 & 21 & 13.9 & - & .. & 4.6 & 6.9 & 3.5 \\
\hline W-30B & 941 & 218 & 21.2 & 54 & - & 1 & 13 & 12 & 4 & 2.6 & .. & -. & 0.9 & 1.3 & 0.6 \\
\hline \multicolumn{4}{|c|}{ ( } & & & & & & $\%$ & & & & & & \\
\hline$W-24$ & 643 & 33 & 1.2 & 18 & -- & $\cdots$ & - & 2 & 1 & 0.2 & 0.1 & $\cdots$ & 3.1 & 0.6 & 2 \\
\hline W-24A & 87 & 7 & 0.6 & 1 & - & - & - & 1 & - & - & .. & .. & 0.5 & 0.2 & 0.3 \\
\hline W-25 & 2039 & 92 & 5.6 & 9 & - & - & 4 & 9 & 3 & 1.3 & 0.1 & $\cdots$ & 15.2 & 1.8 & 5.4 \\
\hline W-26 & 5153 & 145 & 81 & 87 & - & - & 22 & 29 & 9 & 1.8 & 0.2 & -. & 25.5 & 16.1 & 10.4 \\
\hline W-27 & 1710 & 81 & 4 & 6 & -- & -- & 1 & 9 & 3 & 1 & 0.3 & - & 24.8 & 2 & $8.9^{\circ}$ \\
\hline W-30 & 940 & 52 & 1.4 & 4 & - & - & - & 1 & 1 & 0.4 & 0.1 & - & 4.9 & 0.8 & 3.4 \\
\hline$W-31$ & 428 & 36 & 1.9 & 7 & - & - & - & 2 & 1 & 0.3 & 0.2 & - & 3.3 & 0.2 & 1 \\
\hline
\end{tabular}


Table 2.1. Radionuclide content of waste injections conducted at NHF (continued)

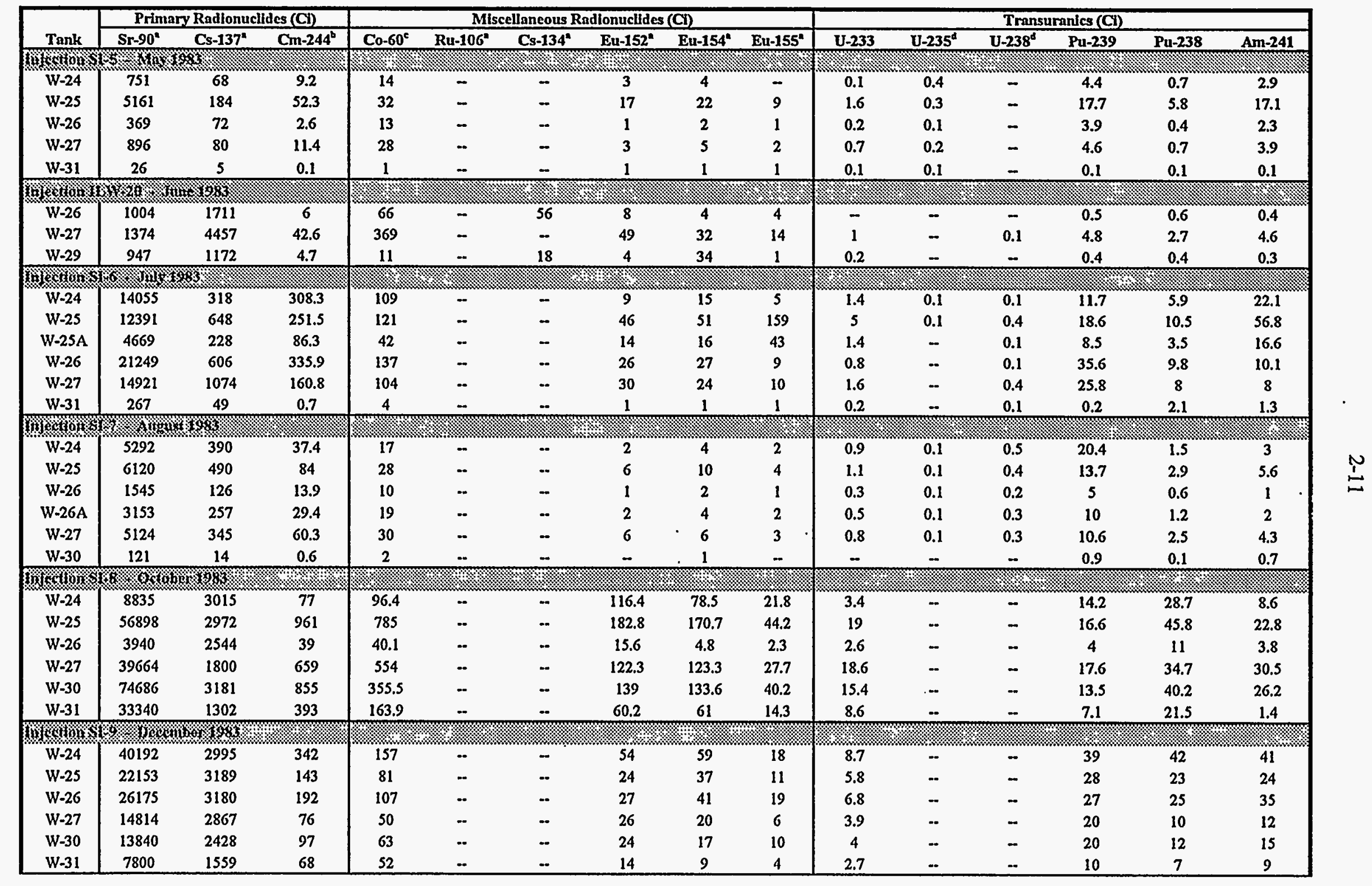


¿partodas pou

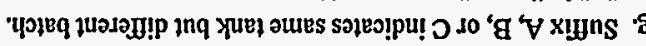

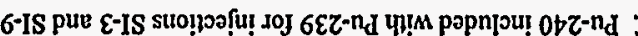

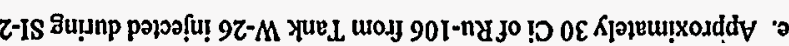

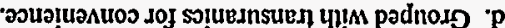
'onposd uo!̣es!̣p 'o

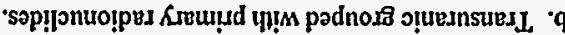

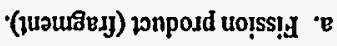

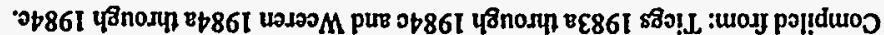

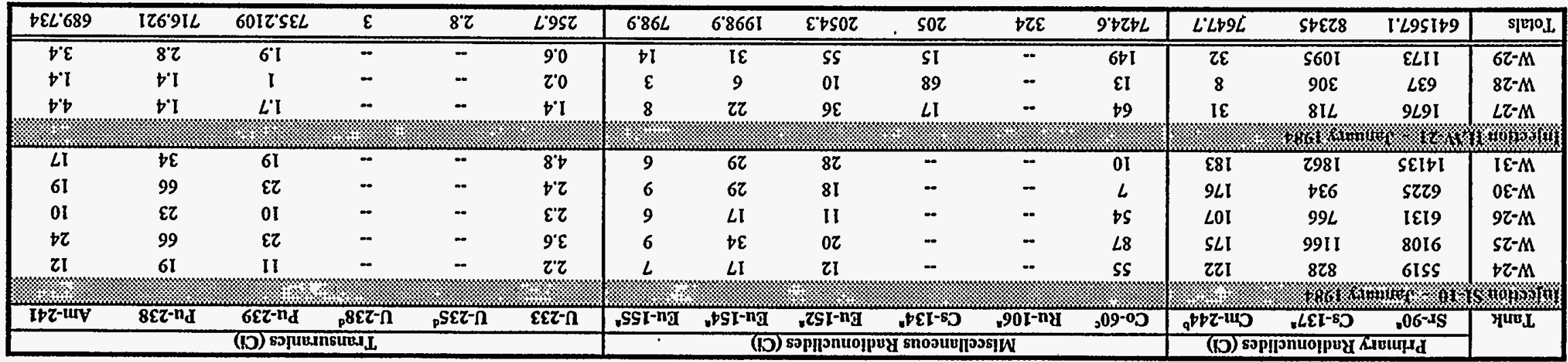

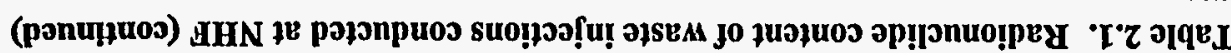


Table 2.2. Composition of dry solids used for New Hydrofracture Facility waste/grout mixtures ${ }^{\circ}$

\begin{tabular}{lcc}
\hline & UW mix & SI mix \\
\hline Ingredient & (weight \%) & (weight \%) \\
Cement (Type 1) & $38.5 \pm 4.0$ & $46.0 \pm 4.0$ \\
\hline Fly ash & $38.5 \pm 4.0$ & \\
& & $46.0 \pm 4.0$ \\
Drilling clay & $15.4 \pm 1.5$ & \\
\hline Pottery clay & $7.7 \pm 0.5$ & $\mathrm{NU}^{b}$ \\
Retarder & 0.05 & 0.05 \\
\hline
\end{tabular}

From Weeren 1984f.

Not used

The retarder was subsequently deleted. 
Table 2.3. New Hydrofracture Facility injection volumes and mixing ratios

\begin{tabular}{|c|c|c|c|c|c|}
\hline Injection & Tank & $\begin{array}{c}\text { Waste } \\
\text { Volume (gal) }\end{array}$ & Solids (lb) & $\begin{array}{c}\text { Mix Ratio } \\
\text { (lb/gal) }\end{array}$ & $\begin{array}{c}\text { Desired } \\
\text { Mix Ratio/Range } \\
\text { (lb/gal) }\end{array}$ \\
\hline \multicolumn{6}{|l|}{ 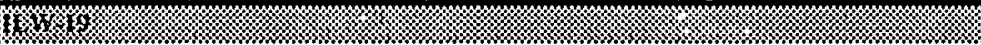 } \\
\hline \multirow[t]{3}{*}{$6 / 16 / 82$} & W-24 & 33,950 & 254,030 & 7.5 & 8 \\
\hline & W-27 & 32,050 & 192,100 & 6.0 & 7 \\
\hline & W-25 & 18,500 & 107,300 & 5.8 & 6 \\
\hline \multirow[t]{4}{*}{$6 / 17 / 82$} & W-25 & 13,240 & 88,770 & 6.7 & 6 \\
\hline & W-26 & 22,930 & 146,760 & 6.4 & 7 \\
\hline & W-26 & 10,605 & 54,340 & 5.1 & 7 \\
\hline & W-29 & 22,290 & 140,170 & 6.3 & 7 \\
\hline \multicolumn{6}{|l|}{$S 4$} \\
\hline \multirow[t]{2}{*}{$8 / 10 / 82$} & W-24 & 3,730 & 2,228 & 0.6 & $5 \cdot 6$ \\
\hline & W-24 & 5,995 & Breakdown & 0.0 & $5-6$ \\
\hline \multirow[t]{3}{*}{$8 / 11 / 82$} & W-24 & 25,230 & 158,850 & 6.3 & $5-6$ \\
\hline & W-25 & 3,805 & 27,210 & 7.2 & 8 \\
\hline & W-25 & 2,985 & 13,380 & 4.5 & 8 \\
\hline \multirow[t]{3}{*}{$8 / 13 / 82$} & W-25 & 3,275 & 6,180 & 1.9 & 8 \\
\hline & W-25 & 4,055 & 4,310 & 1.1 & 8 \\
\hline & W-25 & 11,625 & 77,140 & 6.6 & 8 \\
\hline \multirow[t]{6}{*}{$8 / 14 / 82$} & W-31 & 12,340 & No Solids & 0.0 & 14 \\
\hline & W-31 & 5,520 & 22,230 & 4.0 & 14 \\
\hline & W-25 & 10,805 & 51,260 & 4.7 & 8 \\
\hline & W-26 & 39,845 & 213,200 & 5.4 & 8 \\
\hline & W-27 & 41,875 & 190,260 & 4.5 & 4 \\
\hline & W-30 & 25,080 & 131,530 & 5.2 & 4 \\
\hline \multirow[t]{4}{*}{$8 / 15 / 82$} & W-29 & 9,875 & 34,450 & 3.5 & No Ratio Reported \\
\hline & $W-31$ & 2,375 & 12,260 & 5.2 & 14 \\
\hline & W-28 & 7,605 & 41,740 & 5.5 & No Ratio Reported \\
\hline & W-31 & 4,975 & 20,160 & 4.1 & 14 \\
\hline \multirow{6}{*}{$\frac{1}{9 / 23 / 82}$} & m. & W\% & & w. & \\
\hline & W-26 & 890 & 0 & 0.0 & $4.5-7$ \\
\hline & W-26 & 10,490 & 40,330 & 3.8 & $4.5-7$ \\
\hline & W-26 & 2,255 & 0 & 0.0 & $4.5=7$ \\
\hline & W-26 & 16,675 & 86,530 & 5.2 & $4.5-7$ \\
\hline & W-27 & 10,790 & 57,280 & 5.3 & $4.5-7$ \\
\hline \multirow[t]{3}{*}{$9 / 24 / 82$} & W-27 & 30,100 & 174,980 & 5.8 & $4.5-7$ \\
\hline & W-24 & 43,370 & 285,260 & 6.6 & $6-9$ \\
\hline & W-25 & 2,085 & 12,560 & 6.0 & $6-9$ \\
\hline
\end{tabular}

\begin{tabular}{|c|c|c|c|c|c|}
\hline Injection & Tank & $\begin{array}{c}\text { Waste } \\
\text { Volume (gal) }\end{array}$ & Solids (b) & $\begin{array}{c}\text { Mix llatio } \\
\text { (Ib/gal) }\end{array}$ & $\begin{array}{c}\text { Desired } \\
\text { Mix Ratio/Range } \\
\text { (lb/gal) }\end{array}$ \\
\hline \multirow{4}{*}{$\begin{array}{c}\delta f_{2} \\
10 / 26 / 82\end{array}$} & & & 3 & & x. \\
\hline & W-24 & 16,205 & 76,510 & 4.7 & $4-6$ \\
\hline & W-24 & 24,154 & 95,650 & 4.0 & 4-6 \\
\hline & W-25A & 35,571 & 155,530 & 4.4 & $4-6$ \\
\hline \multirow[t]{4}{*}{$10 / 27 / 82$} & W-26A & 36,055 & 170,330 & 4.7 & $4-6$ \\
\hline & W-27A & 8,135 & 35,700 & 4.4 & 4.6 \\
\hline & W-27A & 6,200 & 26,180 & 4.2 & $4-6$ \\
\hline & W-30A & 25,395 & 126,180 & 5.0 & $4-6$ \\
\hline \multirow[t]{2}{*}{$10 / 28 / 82$} & W-27B & 20,284 & 93,240 & 4.6 & $4-6$ \\
\hline & $\mathrm{W}-25 \mathrm{~B}$ & 30,616 & 135,460 & 4.4 & $4-6$ \\
\hline \multirow[t]{4}{*}{$10 / 29 / 82$} & W-25C & 22,950 & 105,460 & 4.6 & $4-6$ \\
\hline & $W-26 B$ & 11,330 & 34,860 & 3.1 & 4.6 \\
\hline & W-26B & 25,945 & 117,860 & 4.5 & 4.6 \\
\hline & W-30B & 5,105 & 26,110 . & 5.1 & 4.6 \\
\hline \multirow{5}{*}{$4 / 8 / 83$} & & . & m & & \\
\hline & W-24 & 14,795 & 109,980 & 7.4 & $5.5-10$ \\
\hline & W-25 & 30,483 & 131,160 & 4.3 & $4-5$ \\
\hline & W-24 & 11,312 & 75,660 & 6.7 & $5.5-10$ \\
\hline & W-26 & 26,098 & 146,550 & 5.6 & $4-8$ \\
\hline \multirow[t]{5}{*}{$4 / 9 / 83$} & W-26 & 5,450 & 26,110 & 4.8 & $4-8$ \\
\hline & W-27 & 30,835 & 180,760 & 5.9 & $4 \cdot 8$ \\
\hline & W-27 & 1,600 & 1,930 & 1.2 & $4 \cdot 8$ \\
\hline & W-27 & 941 & 2,220 & 2.4 & 4.8 \\
\hline & W-30 & 28,149 & 149,430 & 5.3 & 4.7 \\
\hline \multirow[t]{3}{*}{$4 / 10 / 83$} & W-30 & 4,470 & 26,460 & 5.9 & 4.7 \\
\hline & W-31 & 32,259 & 231,830 & 7.2 & $6 \cdot 10$ \\
\hline & W-24A & 4,101 & 27,870 & 6.8 & 5.9 \\
\hline \multicolumn{6}{|l|}{ S } \\
\hline $5 / 16 / 83$ & W-24 & 21,965 & 155,160 & 7.1 & $4.5-9$ \\
\hline \multirow[t]{3}{*}{$5 / 17 / 83$} & W-24 & 17,375 & 108,510 & 6.2 & $4.5-9$ \\
\hline & W-25 & 32,870 & 192,290 & 5.9 & $4 \cdot 8$ \\
\hline & W-26 & 26,445 & 165,520 & 6.3 & $4-8.5$ \\
\hline \multirow[t]{4}{*}{$5 / 18 / 83$} & W-26 & 11,805 & 74,590 & 6.3 & $4-8.5$ \\
\hline & W-27 & 20,830 & 141,140 & 6.8 & $4.5=9$ \\
\hline & W-27 & 20,640 & 131,150 & 6.4 & $4.5-9$ \\
\hline & W-31 & 3,220 & 16,070 & 5.0 & $4.5-8.5$ \\
\hline
\end{tabular}


Table 2.3. NHF injection volumes and mixing ratios (continued)

\begin{tabular}{|c|c|c|c|c|c|}
\hline Injection & Tank & $\begin{array}{c}\text { Waste } \\
\text { Volume (gal) }\end{array}$ & Solids (lb) & $\begin{array}{c}\text { Mix Ratio } \\
\text { (lb/gal) }\end{array}$ & $\begin{array}{c}\text { Desired } \\
\text { Mix Ratio/Range } \\
\text { (lb/gal) }\end{array}$ \\
\hline How & $\ldots$ & we & \% & 8 & $1 \%$ \\
\hline \multirow[t]{5}{*}{$6 / 14 / 83$} & W-26 & 21,955 & 143,620 & 6.5 & $6-8$ \\
\hline & W-26 & 17,100 & 96,910 & 5.7 & 6.8 \\
\hline & W-27 & 23,980 & 155,240 & 6.5 & $6-8$ \\
\hline & W-27 & 9,530 & 66,790 & 7.0 & $6-8$ \\
\hline & W-29 & 40,820 & 278,740 & 6.8 & $6-8$ \\
\hline \multicolumn{6}{|l|}{ S1. } \\
\hline \multirow[t]{3}{*}{$7 / 12 / 83$} & W-27 & 36,305 & 149,480 & 4.1 & 4 \\
\hline & W-24 & 38,825 & 253,680 & 6.5 & $4-8$ \\
\hline & W-25 & 5,290 & 29,680 & 5.6 & $4-8$ \\
\hline \multirow[t]{3}{*}{$7 / 13 / 83$} & W-25 & 28,110 & 172,250 & 6.1 & $4-8$ \\
\hline & $W-26$ & 37,410 & 183,000 & 4.9 & $4-7$ \\
\hline & W-31 & 23,490 & 143,250 & 6.1 & $4.5-8.5$ \\
\hline \multirow[t]{2}{*}{$7 / 14 / 83$} & W-25 & 23,700 & 142,360 & 6.0 & $4-8$ \\
\hline & W-31 & 10,097 & 58,300 & 5.8 & $4.5-8.5$ \\
\hline \multirow[t]{4}{*}{ KI. } & & & & 8 & ঝ \\
\hline & W-24 & 38,630 & 248,600 & 6.4 & $4-8.5$ \\
\hline & W-25 & 33,998 & 229,040 & 6.7 & $4.5-9$ \\
\hline & W-26 & 15,454 & 99,120 & 6.4 & $4.5-8.5$ \\
\hline \multirow[t]{3}{*}{$8 / 10 / 83$} & W-26A & 29,469 & 175,910 & 6.0 & $4.5-8.5$ \\
\hline & W-27 & 37,679 & 209,590 & 5.6 & $4-8.5$ \\
\hline & W-30 & 7,682 & 38,770 & 5.0 & $4.5-9$ \\
\hline \multicolumn{6}{|l|}{6} \\
\hline \multirow[t]{3}{*}{$10 / 25 / 83$} & W-24 & 36,894 & 148,200 & 4.0 & 5 \\
\hline & W-25 & 32,691 & 126,800 & 3.9 & 5 \\
\hline & W-26 & 20,323 & 84,000 & 4.1 & 4 \\
\hline \multirow[t]{4}{*}{$10 / 26 / 83$} & W-26 & 14,655 & 53,600 & 3.7 & 4 \\
\hline & W-27 & 34,978 & 135,070 & 3.9 & 5 \\
\hline & W-30 & 34,666 & 114,330 & 3.3 & 4 \\
\hline & $W-31$ & 17,686 & 82,000 & 4.6 & 4 \\
\hline
\end{tabular}

\begin{tabular}{|c|c|c|c|c|c|}
\hline Injection & Tank & $\begin{array}{c}\text { Waste } \\
\text { Volume (gal) }\end{array}$ & Solids (Ib) & $\begin{array}{l}\text { Mix Ratio } \\
\text { (lb/gal) }\end{array}$ & $\begin{array}{c}\text { Desired } \\
\text { Mix Ratio/Range } \\
\text { (lib/gal) }\end{array}$ \\
\hline \multicolumn{6}{|l|}{$8 x=2$} \\
\hline $11 / 30 / 83$ & W-24 & 10,755 & 36,600 & 3.4 & 4 \\
\hline \multirow[t]{4}{*}{$12 / 1 / 83$} & W-24 & 24,703 & 90,480 & 3.7 & 4 \\
\hline & $W-25$ & 32,343 & 137,477 & 4.3 & 4 \\
\hline & $W-26$ & 35,689 & 149,731 & 4.2 & 4 \\
\hline & W-27 & 20,420 & 81,902 & 4.0 & 4. \\
\hline \multirow[t]{3}{*}{$12 / 2 / 83$} & W-27 & 13,528 & 54,270 & 4.0 & 4 \\
\hline & $W-30$ & 31,969 & 128,046 & 4.0 & 4 \\
\hline & W-31 & 21,503 & 89,334 & 4.2 & 4 \\
\hline \multicolumn{6}{|l|}{ 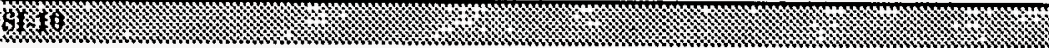 } \\
\hline \multirow[t]{2}{*}{$1 / 25 / 84$} & W.25 & 36,433 & 144,621 & 4.0 & 4 \\
\hline & W-24 & 39,442 & 258,577 & 6.6 & 7 \\
\hline $1 / 26 / 84$ & W-26 & 38,319 & 170,610 & 4.5 & 5 \\
\hline \multirow[t]{2}{*}{$1 / 27 / 84$} & W-30 & 34,586 & 138,670 & 4.0 & 4 \\
\hline & $W-31$ & 34,475 & 143,302 & 4.2 & 4 \\
\hline \multirow{3}{*}{$\frac{1 / 1 / 27 / 84}{1 / 2}$} & ঋ & \% & x. & & \\
\hline & W-27 & 31,477 & 176,374 & 5.6 . & $6-8$ \\
\hline & W-28 & 3,521 & 19,910 & $5.7^{\circ}$ & 6.8 \\
\hline \multirow[t]{3}{*}{$1 / 28 / 84$} & $W-28$ & 39,428 & 221,933 & 5.6 & $6-8$ \\
\hline & W-29 & 39,107 & 225,627 & 5.8 & $6-8$ \\
\hline & W-27 & 8,425 & 40,919 & 4.9 & $6-8$ \\
\hline
\end{tabular}

Compiled from: Tiegs 1983a through 1984c and Weeren 1984a through 19840 
Table 2.4. Summary of waste/grout volumes and radionuclide content injected at the New Hydrofracture Facility

\begin{tabular}{|c|c|c|c|c|c|c|c|c|c|c|}
\hline \multirow[b]{2}{*}{ Injection } & \multirow[b]{2}{*}{ Date } & \multicolumn{3}{|c|}{ Volume $\left(\mathrm{yd}^{3}\right)$} & \multicolumn{6}{|c|}{ Radionuclide Content (Ci) } \\
\hline & & Waste & Grout & Subtotal & $\mathrm{Sr}-90^{a}$ & $\mathrm{Cs}-137^{a}$ & $\mathrm{Cm}-244^{b}$ & Transuranics & Miscellaneous & Subtotal \\
\hline \multicolumn{5}{|c|}{ 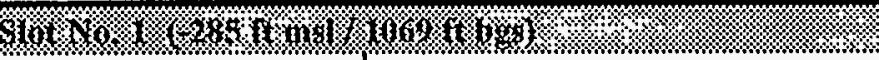 } & & I & & $\%$ & & \\
\hline $\mathrm{ILW}-19^{\circ}$ & Jun-82 & 792.2 & 1128.9 & 1921.1 & 156 & 17333 & 5 & 2 & 347 & 17843 \\
\hline $\mathrm{SI}-1^{d}$ & Aug-82 & 950.6 & 1559.3 & 2509.9 & 36711.1 & 5500 & 710 & 72 & 2000 & 44993.1 \\
\hline SI-2 & Sep-82 & 574.4 & 762.5 & 1336.9 & 57200 & 4800 & $\mathrm{NR}^{e}$ & 73 & 1400 & 63473 \\
\hline SI-3 & Oct-82 & 1227.9 & 1529.2 & 2757.1 & 61000 & 4100 & 510 & 290 & 1800 & 67700 \\
\hline \multicolumn{5}{|c|}{ 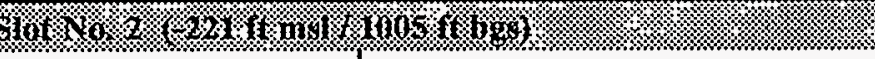 } & & & & ?. & & \\
\hline SI-4 & Apr-83 & 960.5 & 1208.0 & 2168.6 & 11000 & 450 & 96 & 130 & 230 & 11906 \\
\hline SI-5 & May-83 & 782.2 & 811.9 & 1594.2 & 7200 & 410 & 76 & 65 & 160 & 7911 \\
\hline ILW-20 & Jun-83 & 549.5 & 767.5 & 1317.0 & 3266 & 7140 & 53 & 14 & 627 & 11100 \\
\hline SI-6 & Jul-83 & 1010.0 & 1239.8 & 2249.8 & 67553 & 2750 & 1060 & 240 & 930 & 72533 \\
\hline SI-7 & Aug-83 & 806.6 & 939.7 & 1746.3 & 21630 & 2585 & 220 & 84 & 160 & 24679 \\
\hline \multicolumn{5}{|c|}{ 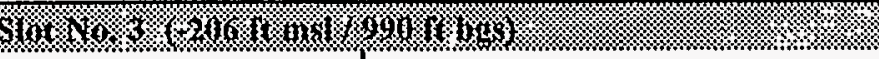 } & & & & & 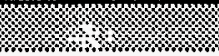 & \\
\hline SI-8 & Oct-83 & 970.5 & 1198.2 & 2168.7 & 217400 & 14800 & 2980 & 357 & 3400 & 238937 \\
\hline SI-9 & Dec-83 & 943.7 & 1181.3 & 2125.0 & 125000 & 16200 & 920 & 404 & 990 & 143514 \\
\hline SI-10 & Jan-84 & 915.9 & 1237.9 & 2153.8 & 41100 & 5600 & 763 & 375 & 760 & 48598 \\
\hline ILW-21 & Jan-84 & 604.1 & 792.2 & 1396.3 & 3500 & 2100 & 71 & 19 & 510 & 6200 \\
\hline \multicolumn{2}{|c|}{ Totals } & 11,088 & 14,356 & 25,445 & 652,716 & 83,768 & 7,464 & 2,125 & 13,314 & 759,387 \\
\hline
\end{tabular}

Compiled from: Tiegs 1983a through $1984 \mathrm{c}$ and Weeren 1984a through 1984e

Notc: $\quad$ a. Fission product (fragment).

b. Transuranic listed as primary radionuclide.

c. SI - sludge injection.

d. ILW - intermediate-level waste.

c. NR - not reported. 
Table 2.5. WAG $10 \mathrm{New}$ Hydrofracture Facility well construction details

\begin{tabular}{|c|c|c|c|c|c|c|c|c|c|c|c|}
\hline \multirow[b]{2}{*}{ Station } & \multirow[b]{2}{*}{ Alias } & \multirow[b]{2}{*}{ Northing } & \multirow[b]{2}{*}{ Easting } & \multirow{2}{*}{$\begin{array}{l}\text { GS Elev. } \\
\text { (ft msl) }\end{array}$} & \multicolumn{3}{|c|}{ Riser Casing } & \multirow{2}{*}{$\begin{array}{l}\text { Borehole } \\
\text { Depth (ft) }\end{array}$} & \multirow{2}{*}{$\begin{array}{l}\text { Formation at } \\
\text { Total Depth }\end{array}$} & \multirow{2}{*}{$\begin{array}{c}\text { Open } \\
\text { Interval }\end{array}$} & \multirow{2}{*}{$\begin{array}{c}\text { Installation } \\
\text { Date }\end{array}$} \\
\hline & & & & & ID (in.) & Material & Depth (ft) & & & & \\
\hline \multicolumn{2}{|c|}{ BMI G } & , & & & & & & & 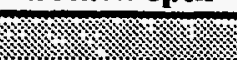 & 1 & 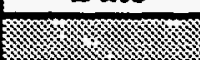 \\
\hline 1969 & 4E-200RC & 28376.61 & 16487.09 & 788.59 & 4 & C.Steel & 550 & 650 & $\in \mathrm{rt}$ & $\in \mathrm{rg}, \in \mathrm{rt}$ & 1980 \\
\hline 1971 & $4 \mathrm{~N}-200 \mathrm{RC}$ & 28168.74 & 16716.33 & 767.99 & 4 & C.Steel & 480 & $580^{a}$ & $\in \mathrm{rt}$ & $\in \mathrm{rg}, \in \mathrm{rt}$ & 1980 \\
\hline 1973 & 4NE-280RC & 28434.92 & 16661.52 & 764.77 & 4 & C.Steel & 480 & 582 & $\in \mathrm{rt}$ & $\in \mathrm{rg}, \in \mathrm{rt}$ & 1980 \\
\hline 1974 & $4 N W-340 R C$ & 27884.13 & 16695.8 & 769.33 & 4 & C.Steel & 480 & 580 & $\in \mathrm{rg}$ & $\in \mathrm{rg}$ & 1980 \\
\hline 1976 & $4 S-200 R C$ & 28204.99 & 16305.45 & 800.51 & 4 & C.Steel & 600 & 700 & $\in \mathrm{rt}$ & $\in \mathrm{rg}, \in \mathrm{rt}$ & 1980 \\
\hline 1979 & 4SE-280RC & 28382.46 & 16303.52 & 814.18 & 4 & C.Steel & 600 & 700 & $\in \mathrm{rt}$ & $\in \mathrm{rg}, \in \mathrm{rt}$ & 1980 \\
\hline 1980 & $4 S W-280 R C$ & 27922.1 & 16372.21 & 785.23 & 4 & C.Steel & 600 & 700 & $\in \mathrm{rt}$ & Ert & 1980 \\
\hline 1981 & $4 \mathrm{~W}-190 \mathrm{RC}$ & 27984.56 & 16472.85 & 783.28 & 4 & C.Steel & 550 & $650^{b}$ & $\in \mathrm{rt}$ & $\in \mathrm{rg}, \in \mathrm{rt}$ & 1980 \\
\hline \multicolumn{2}{|c|}{ 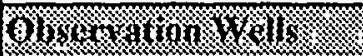 } & \% & 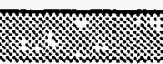 & 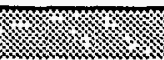 & 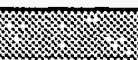 & (2) & 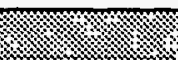 & & 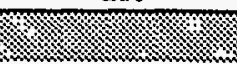 & 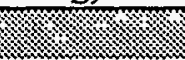 & $x \times$ \\
\hline $1970^{\circ}$ & $4 \mathrm{E}-200 \mathrm{~W}$ & 28374.93 & 16505.15 & 787.89 & 1.25 & C.Steel & 1135 & 1135 & $\in \mathrm{r}$ & - & 1973 \\
\hline 1972 & $4 N-200 W$ & 28175.75 & 16705.16 & 768.17 & 2.88 & C.Steel & 1120 & 1120 & $\in \mathbf{r}$ & $-\infty$ & 1973 \\
\hline 1975 & $4 \mathrm{NW}-400 \mathrm{~W}$ & 27909 & 16703.7 & 770.34 & 2.88 & C.Steel & 986 & 986 & $l \in p v$ & - & 1980 \\
\hline 1977 & $4 S-200 W$ & 28176.23 & 16306.72 & 799.09 & 2.88 & C.Steel & 1102 & 1200 & $l \in p v$ & - & 1973 \\
\hline 1978 & 4SE-125W & 28304.7 & 16447.69 & 786.78 & 4 & C.Steel & 1145 & 1145 & $\in \mathrm{r}$ & -. & 1980 \\
\hline 1982 & $4 W-200 W$ & 27975.23 & 16504.8 & 782.63 & 2.88 & C.Steel & 1107 & 1152 & $\in \mathrm{r}$ & - & 1973 \\
\hline \multicolumn{3}{|c|}{ 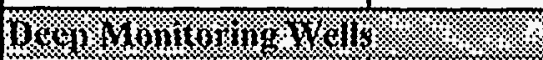 } & 1.\%.।. & ৷: & (1). & \multicolumn{2}{|c|}{ (4) } & (x) & $1.1 \%$ & 1 & \%) \\
\hline 2373 & DM1-RM & 29219.51 & 16645.54 & 765.42 & 4 & C.Steel & 1092 & $1149^{d}$ & $\in \mathrm{r}$ & $\in \mathrm{r}$ & 1985 \\
\hline 2374 & DM2-RM & 27075.2 & 16456.59 & 757.78 & 4 & C.Steel & 1084 & $1275^{c}$ & $\in \mathrm{E}$ & $l \in p v, \in r$ & 1985. \\
\hline 2375 & DM3A-PV & 27311.94 & 17413.8 & 768.89 & 6 & C.Steel & 550 & $910^{r}$ & $u \in p v$ & $\epsilon \mathrm{rt}, \mathrm{u} \in \mathrm{pv}$ & 1985 \\
\hline $\begin{array}{l}2952 \\
2953\end{array}$ & $\begin{array}{l}\text { DM1-RT } \\
\text { DM3-RT }\end{array}$ & $\begin{array}{l}29238.29 \\
2721453\end{array}$ & $\begin{array}{l}16649.77 \\
1698395\end{array}$ & $\begin{array}{l}765.52 \\
75351\end{array}$ & $\begin{array}{l}6 \\
4\end{array}$ & $\begin{array}{l}\text { C. Steel } \\
\text { C.Steel }\end{array}$ & $\begin{array}{l}615 \\
552\end{array}$ & $\begin{array}{l}721 \\
615\end{array}$ & $\in \mathrm{rt}$ & $\in \mathrm{rt}$ & 1985 \\
\hline $2954^{8}$ & DM1-PV & 29227.37 & 16664.37 & 765.45 & 6 & C.Steel & 750 & 1063 & $l \in p v$ & $u \in p v, l \in p v$ & 1985 \\
\hline $2955^{8}$ & DM2-PV & 27091.44 & 16469.95 & 758.54 & 6 & C.Steel & 750 & 1063 & $l \in p v$ & $u \in p v, l \in p v$ & 1985 \\
\hline
\end{tabular}

Note: - Data gathered from various sources.

d. DM1-RM was drilled to $1487^{\prime}$ and then plugged back to $1149^{\prime}$ with grout.

a. Geophones and sand installed up to a depth of $410 \mathrm{ft}$ bgs in well 1971. e. DM2-RM was drilled to 1505 ' and then plugged back to $1275^{\prime}$ with grout.

b. Geophones and sand installed up to a depth of $528 \mathrm{ft}$ bgs in well 1981. f. DM3A-PV was drilled to 1166 ' and then plugged back to 910 ' with grout.

c. Well 1970 is a small diameter well (1.25 ID) and was not geophysically logged or sampled.

g. Buildings $7802 \mathrm{C}$ and $7802 \mathrm{D}$ are installed over top of

wells 2954 (DM1-PV) and 2955 (DM2-PV), respectively. 
Table 2.6. Rock cover well pressure tests conducted at the New Hydrofracture Facility

\begin{tabular}{|c|c|c|c|c|c|c|c|c|c|}
\hline \multirow[b]{2}{*}{ Date } & \multirow[b]{2}{*}{ Time } & \multicolumn{8}{|c|}{ Pressure (psig) } \\
\hline & & $\begin{array}{c}1971 \\
(4 N-200 R C)\end{array}$ & $\begin{array}{c}1973 \\
\text { (4NE-280RC) }\end{array}$ & $\begin{array}{c}1969 \\
(4 \mathrm{E}-200 \mathrm{RC})\end{array}$ & $\begin{array}{c}1979 \\
\text { (4SE-280RC) }\end{array}$ & $\begin{array}{c}1976 \\
(4 \mathrm{~S}-200 \mathrm{RC})\end{array}$ & $\begin{array}{c}1980 \\
(4 S W-280 R C)\end{array}$ & $\begin{array}{c}1981 \\
\text { (4W-190RC) }\end{array}$ & $\begin{array}{c}1974 \\
(4 \mathrm{NW}-340 \mathrm{RC})\end{array}$ \\
\hline \multirow{8}{*}{$\begin{array}{c}6 / 16 / 82 \\
6\end{array}$} & \% & k & $\times$ & & 8 & & & $8 \%$ & \%\$\% \\
\hline & $8: 00$ & 3 & -6 & -15 & -4 & -9 & 9 & -15 & -5 \\
\hline & $10: 00$ & 3 & -6 & -15 & -4 & -9 & 9 & -15 & -5 \\
\hline & $12: 00$ & 3 & -6 & -15 & -4 & -8 & 9 & -15 & -5 \\
\hline & $14: 00$ & 3 & -6 & -15 & -4 & -8 & 9 & -15 & -2 \\
\hline & $16: 00$ & 3 & -6 & -15 & -5 & -8 & 8 & -15 & 0 \\
\hline & $18: 00$ & 5 & -5 & -16 & -5 & -10 & 8 & -16 & 4 \\
\hline & $20: 00$ & 7 & -5 & -16 & -5 & -10 & 8 & -16 & 6 \\
\hline \multirow{6}{*}{$6 / 17 / 82$} & $8: 00$ & 7 & -7 & -16 & -5 & -7 & 8 & -16 & 8 \\
\hline & $10: 00$ & 11 & -6 & -16 & -5 & -10 & 9 & -15 & 8 \\
\hline & $12: 00$ & 12 & -5 & -16 & -5 & -12 & 8 & -17 & 8 \\
\hline & $14: 00$ & 13 & -5 & -16 & -5 & -10 & 8 & -16 & 8 \\
\hline & $16: 00$ & 14 & -5 & -16 & -5 & -10 & 8 & -16 & 8 \\
\hline & $18: 00$ & 15 & -5 & -16 & -5 & -10 & 9 & -16 & 8 \\
\hline \multicolumn{2}{|l|}{ 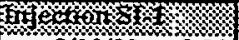 } & & & & & & & x. & $\%$ \\
\hline \multirow[t]{5}{*}{$8 / 10 / 82$} & $8: 30$ & 19 & 2 & -24 & -18 & -20 & 22 & -12 & 10 \\
\hline & $10: 30$ & 19 & 2 & -24 & -19 & -20 & 22 & -14 & 9 \\
\hline & $12: 30$ & .19 & 2 & -24 & -19 & -18 & 22 & -13 & 10 \\
\hline & $14: 30$ & 19 & 2 & -23 & -19 & -18 & 22 & -13 & 10 \\
\hline & $16: 30$ & 20 & 2 & -23 & -19 & -18 & 23 & -13 & 10 \\
\hline \multirow[t]{6}{*}{$8 / 11 / 82$} & $8: 30$ & 21 & 0 & -24 & -19 & -19 & 22 & -12 & 10 \\
\hline & $10: 30$ & 23 & 0 & -24 & -19 & -19 & 26 & -12 & 10 \\
\hline & $12: 30$ & 24 & 0 & -24 & -19 & -19 & 26 & -12 & 10 \\
\hline & $14: 30$ & 24 & 0 & -24 & -19 & -19 & 26 & -12 & 10 \\
\hline & $16: 30$ & 26 & 0 & -24 & -19 & -19 & 22 & -12 & 10 \\
\hline & 18:30 & 26 & 0 & -24 & -20 & -19 & 22 & -12 & 10 \\
\hline \multirow[t]{4}{*}{$8 / 13 / 82$} & $8: 30 \mid$ & 29 & 1 & -24 & -18 & -19 & 23 & -10 & 11 \\
\hline & $10: 30$ & 30 & 1 & -24 & -16 & -19 & 23 & -10 & 11 \\
\hline & $13: 45$ & 31 & 1 & -24 & -16 & -19 & 23 & -10 & 11 \\
\hline & $15: 50$ & 32 & 1 & -24 & -16 & -19 & 23 & -9 & 12 \\
\hline \multirow[t]{6}{*}{$8 / 14 / 82$} & $13: 00$ & 36 & 4 & -24 & -17 & -19 & 24 & -9 & 13 \\
\hline & 15:00 & 37 & 4 & -24 & -16 & -19 & 24 & -7 & 18 \\
\hline & $17: 00$ & 37 & 4 & -24 & -15 & -16 & 25 & -6 & 18 \\
\hline & 19:00 & 37 & 5 & -25 & -16 & -17 & 25 & -6 & 19 \\
\hline & 21:00 & 38 & 4 & -24 & -16 & -17 & 27 & -5 & 22 \\
\hline & 23:00 & 36 & 4 & -24 & -16 & -17 & 32 & -5 & 26 \\
\hline \multirow[t]{2}{*}{$8 / 15 / 82$} & $1: 00$ & 37 & 4 & -24 & -16 & -20 & 34 & -5 & 30 \\
\hline & 3:00 & 37 & 4 & -24 & -17 & -20 & 38 & 0 & 32 \\
\hline \multicolumn{2}{|l|}{ Hifecto } & & & & & & & & \\
\hline \multirow[t]{3}{*}{$9 / 23 / 82$} & $14: 00$ & 41 & 0 & -26 & -24 & -21 & 51 & 19 & 32 \\
\hline & $16: 30$ & 42 & 0 & -26 & -24 & -22 & 52 & 19 & 32 \\
\hline & 18:30 & 42 & 0 & -26 & -22 & -20 & 52 & 19 & 32 \\
\hline $9 / 24 / 82$ & $10: 30$ & 43 & 0 & -26 & -20 & -20 & 52 & 22 & 33 \\
\hline & $13: 00$ & 45 & 0 & -26 & -25 & -22 & 52 & 23 & 33 \\
\hline & $15: 00$ & 44 & 0 & -26 & -25 & -22 & 52 & 25 & 38 \\
\hline & 17:00 & 45 & 0 & -26 & -25 & -22 & 52 & 27 & 44 \\
\hline & 19:00 & 44 & 0 & -26 & -25 & -21 & 53 & 28 & 50 \\
\hline 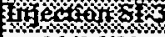 & & & & & & & & $\%$ & \% \\
\hline $10 / 26 / 82$ & $11: 30$ & 46 & 0 & -24 & -23 & -21 & 69 & 31 & 45 \\
\hline & $15: 00$ & 46 & 0 & -25 & -25 & -23 & 70 & 32 & 45 \\
\hline & $18: 15$ & 53 & 0 & -24 & -24 & -21 & 70 & 33 & 45 \\
\hline $10 / 27 / 82$ & 9:30| & 57 & 9 & -24 & -24 & -21 & 69 & 32 & 45 \\
\hline & $11: 30$ & 60 & 9 & -25 & -24 & -22 & 70 & 32 & 45 \\
\hline & $13: 30$ & 65 & 12 & -24 & -24 & -22 & 70 & 33 & 45 \\
\hline & $15: 45$ & 65 & 12 & -24 & -24 & -22 & 70 & 33 & 45 \\
\hline & $17: 45$ & 68 & 12 & -24 & -24 & -22 & 70 & 33 & 45 \\
\hline $10 / 28 / 82$ & $9: 00$ & 70 & 17 & -24 & -24 & -21 & 70 & 30 & 45 \\
\hline & $11: 00$ & 74 & 18 & -24 & -24 & -21 & 70 & 31 & 45 \\
\hline $10 / 29 / 82$ & 11:00 & 78 & 25 & -24 & -24 & -21 & 70 & 28 & 43 \\
\hline & $13: 00$ & 82 & 30 & -24 & -24 & -21 & 70 & 28 & 43 \\
\hline & $15: 00$ & 85 & 30 & -24 & -24 & -22 & 70 & 28 & 42 \\
\hline
\end{tabular}


Table 2.6. Rock cover well pressure tests conducted at NHF (cont.)

\begin{tabular}{|c|c|c|c|c|c|c|c|c|c|}
\hline \multirow[b]{2}{*}{ Date } & \multirow[b]{2}{*}{ Time } & \multicolumn{8}{|c|}{ Pressure (psig) } \\
\hline & & $\begin{array}{c}1971 \\
\text { (4N-200RC) } \\
\end{array}$ & $\begin{array}{c}1973 \\
\text { (4NE-280RC) }\end{array}$ & $\begin{array}{c}1969 \\
(4 \mathrm{E}-200 \mathrm{RC})\end{array}$ & $\begin{array}{c}1979 \\
\text { (4SE-280RC) } \\
\end{array}$ & $\begin{array}{c}1976 \\
(4 S-200 R C) \\
\end{array}$ & $\begin{array}{c}1980 \\
\text { (4SW-280RC) }\end{array}$ & $\begin{array}{c}1981 \\
\text { (4W-190RC) }\end{array}$ & $\begin{array}{c}1974 \\
(4 \mathrm{NW}-340 \mathrm{RC})\end{array}$ \\
\hline & \% & \% & וা পা & 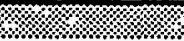 & 签 & « & \%. & \% \\
\hline \multirow[t]{7}{*}{$4 / 8 / 83$} & $8: 30$ & 43 & 17 & 0 & 0 & 0 & 47 & 16 & 21 \\
\hline & $10: 30$ & 44 & 17. & 0 & 0 & 0 & 47 & 16 & 21 \\
\hline & $12: 30$ & 46 & 17 & 0 & 0 & 0 & 47 & 16 & 22 \\
\hline & $13: 00$ & 51 & 17 & 0 & 0 & 0 & 47 & 17 & 23 \\
\hline & $14: 30$ & 57 & 18 & 0 & 0 & 0 & 47 & 19 & 27 \\
\hline & $16: 30$ & 63 & 18 & 0 & 0 & 0 & 46 & 21 & 28 \\
\hline & 18:30 & 68 & 19 & 0 & 0 & 0 & 47 & 22 & 30 \\
\hline \multirow[t]{5}{*}{$4 / 9 / 83$} & $9: 30$ & 73 & 23 & 0 & 0 & 0 & 47 & 23 & 35 \\
\hline & $11: 30$ & 74 & 23 & 0 & 0 & 0 & 51 & 26 & 35 \\
\hline & $13: 30$ & 75 & 23 & 0 & 0 & $\mathbf{0}$ & 61 & 30 & 35 \\
\hline & $15: 30$ & 75 & 23 & 0 & 0 & 0 & 64 & 30 & 35 \\
\hline & $17: 30$ & 75 & 23 & 0 & 0 & 0 & 69 & 33 & 36 \\
\hline \multirow[t]{3}{*}{$4 / 10 / 83$} & $9: 00$ & 74 & 23 & 0 & 0 & 0 & 78 & 38 & 38 \\
\hline & 11:00 & 75 & 23 & 0 & 0 & 0 & 78 & 39 & 38 \\
\hline & 13:00 & 76 & 22 & 0 & 0 & 0 & 80 & 39 & 38 \\
\hline \multicolumn{2}{|l|}{ Hingons } & & & & & & & & 郦 \\
\hline \multirow[t]{3}{*}{$5 / 16 / 83$} & $9: 00$ & 68 & -15 & 10 & 20 & 0 & 78 & 39 & 33 \\
\hline & $14: 00$ & 69 & 20 & 10 & -14 & 5 & 78 & 40 & 34 \\
\hline & $16: 00$ & 69 & 20 & 10 & -14 & 5 & 79 & 43 & 39 \\
\hline \multirow[t]{5}{*}{$5 / 17 / 83$} & $8: 45$ & 69 & -15 & 10 & 20 & 0 & 78 & $\overline{43}$ & 40 \\
\hline & $10: 30$ & 69 & 22 & 10 & -14 & 0 & 78 & 44 & 40 \\
\hline & $12: 30$ & 69 & 20 & 10 & -14 & 0 & 78 & 44 & 40 \\
\hline & $14: 30$ & 74 & 20 & 10 & -14 & 0 & 78 & 48 & 48 \\
\hline & $16: 30$ & 77 & 20 & 10 & -14 & 0 & 84 & 52 & 54 \\
\hline \multirow[t]{5}{*}{$5 / 18 / 83$} & $8: 00$ & 84 & 20 & 10 & -15 & 0 & 96 & 59 & 59 \\
\hline & $10: 00$ & 86 & 20 & 10 & -15 & 0 & 97 & 59 & 59 \\
\hline & $12: 00$ & 93 & 20 & 10 & -15 & 0 & 99 & 59 & 59 \\
\hline & $14: 00$ & 95 & 20 & 15 & -15 & -4 & 99 & 58 & 59 \\
\hline & 16:00 & 95 & 20 & 15 & -15 & -4 & 105 & 60 & 66 \\
\hline \multirow{2}{*}{$\frac{5 / 19 / 83}{5 / 20 / 83}$} & $10: 00$ & 98 & 20 & 14 & -15 & -6 & 106 & 62 & 70 \\
\hline & $10: 00$ & 100 & 20 & 14 & ND & -5 & ND & 62 & 69 \\
\hline \multirow{2}{*}{$\frac{5 / 24 / 83}{5 / 25 / 83}$} & $10: 00$ & 106 & 20 & 14 & -15 & -5 & 106 & 59 & 67 \\
\hline & $10: 00$ & 106 & 20 & 13 & -16 & -5 & 106 & 58 & 66 \\
\hline $5 / 27 / 83$ & $10: 00$ & 106 & 18 & 13 & -15 & -2 & 106 & 57 & 65 \\
\hline \multirow{2}{*}{$\begin{array}{r}5 / 31 / 83 \\
6 / 2 / 83 \\
\end{array}$} & $10: 00$ & 105 & 18 & 13 & -15 & 0 & 106 & 56 & 62 \\
\hline & $10: 00$ & 105 & 22 & 13 & -15 & 0 & 106 & 56 & 62 \\
\hline \multirow{2}{*}{$\frac{6 / 3 / 83}{6 / 6 / 83}$} & $10: 00$ & 105 & 22 & 13 & -15 & 0 & 106 & 56 & 62 \\
\hline & 10:00 & 103 & 22 & 14 & -24 & 0 & 106 & 56 & 62 \\
\hline $6 / 8 / 83$ & $10: 00$ & 102 & 22 & 13 & -25 & 0 & ND & 55 & ND \\
\hline 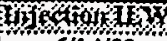 & $320 \%$ & \% & \% & x & & & & 18 & $\infty \times$ \\
\hline $6 / 14 / 83$ & $8: 00$ & 66 & 20 & 8 & 0 & 0 & 86 & 39 & 55 \\
\hline & 10:00 & 75 & 20 & 10 & 0 & 0 & 86 & 43 & 55 \\
\hline & $14: 00$ & 83 & 20 & 10 & 0 & 0 & 87 & 45 & 55 \\
\hline & $16: 00$ & 88 & 22 & 10 & 0 & 0 & 92 & $43^{a}$ & 56 \\
\hline & 18:15 & 92 & 22 & 10 & 0 & 0 & 100 & 39 & 57 \\
\hline $6 / 15 / 83$ & $8: 00$ & 97 & 22 & 10 & 0 & 0 & 100 & 56 & 57 \\
\hline & $10: 00$ & 102 & 21 & 14 & 0 & 0 & 100 & 57 & 60 \\
\hline & $12: 00$ & 104 & 21 & 13 & 0 & 0 & 105 & 58 & 62 \\
\hline & $14: 00$ & 105 & 21 & 13 & 0 & 0 & 105 & 54 & 67 \\
\hline $6 / 17 / 83$ & 13:00 & 110 & 20 & 12 & 0 & 0 & 105 & 39 & 66 \\
\hline $6 / 20 / 83$ & $14: 00$ & 110 & 20 & 12 & -5 & 0 & 105 & 44 & 66 \\
\hline $6 / 27 / 83$ & $13: 00$ & $30^{\circ}$ & 20 & $11^{\circ}$ & -10 & 0 & 105 & $36^{\circ}$ & 66 \\
\hline
\end{tabular}


Table 2.6. Rock cover well pressure tests conducted at NFF (cont.)

\begin{tabular}{|c|c|c|c|c|c|c|c|c|c|}
\hline \multirow[b]{2}{*}{ Date } & \multirow[b]{2}{*}{ Time } & \multicolumn{8}{|c|}{$\begin{array}{ccc} & & \text { Pressure (psig) } \\
1971 & 1973 & 1060\end{array}$} \\
\hline & & $\begin{array}{c}1971 \\
(4 \mathrm{~N}-200 \mathrm{RC})\end{array}$ & $\begin{array}{c}1973 \\
\text { (4NE-280RC) }\end{array}$ & $\begin{array}{c}1969 \\
(4 \mathrm{E}-200 \mathrm{RC})\end{array}$ & $\begin{array}{c}1979 \\
\text { (4SE-280RC) }\end{array}$ & $\begin{array}{c}1976 \\
(4 S-200 R C) \\
\end{array}$ & $\begin{array}{c}1980 \\
(4 S W-280 R C)\end{array}$ & $\begin{array}{c}1981 \\
(4 \mathrm{~W}-190 \mathrm{RC})\end{array}$ & $\begin{array}{c}1974 \\
(4 \mathrm{NW}-340 \mathrm{RC})\end{array}$ \\
\hline 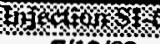 & & & & & & 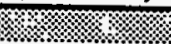 & \% & $\%$ & \\
\hline $7 / 12 / 83$ & $12: 00$ & 86 & 21 & 10 & -13 & 0 & 105 & 38 & 66 \\
\hline & $8: 30$ & 87 & 21 & 10 & -15 & 0 & 105 & 38 & 65 \\
\hline & $10: 30$ & 88 & 21 & 11 & -15 & 0 & 105 & 40 & 66 \\
\hline & $12: 00$ & 89 & 21 & 11 & -14 & 0 & 105 & 42 & 66 \\
\hline & $14: 00$ & 89 & 21 & 11 & -14 & 0 & 120 & 42 & 66 \\
\hline & $16: 00$ & 88 & 21 & 11 & -14 & 0 & 127 & 47 & 66 \\
\hline & $17: 50 \mid$ & 86 & 20 & 7 & -15 & 0 & 134 & 51 & 70 \\
\hline $7 / 13 / 83$ & $8: 15$ & 82 & 18 & $\overline{6}$ & -15 & 0 & 135 & 54 & 71 \\
\hline & $10: 15$ & 84 & 19 & 10 & -17 & 0 & 136 & 54 & 71 \\
\hline & $12: 30$ & 90 & 19 & 10 & -17 & 0 & 136 & 54 & 71 \\
\hline & $14: 00$ & 96 & 19 & 14 & -18 & 0 & 133 & 53 & 71 \\
\hline & $16: 00$ & 101 & 29 & 14 & -17 & 0 & 132 & 50 & 71 \\
\hline & $17: 30$ & $60^{c}$ & 34 & 16 & -18 & 0 & 130 & $48^{6}$ & 71 \\
\hline $7 / 14 / 83$ & $8: 15$ & $38^{6}$ & 34 & 16 & -17 & -5 & 130 & $48^{c}$ & 70 \\
\hline & $10: 45$ & $55^{c}$ & 35 & 17 & -17 & 0 & 129 & $50^{\epsilon}$ & 70 \\
\hline & $13: 00$ & $74^{\circ}$ & 37 & 28 & -17 & neg & 128 & $47^{\circ}$ & 70 \\
\hline $7 / 15 / 83$ & $10: 00$ & $48^{6}$ & 38 & $24^{c}$ & -17 & -5 & 125 & $47^{\circ}$ & 70 \\
\hline $7 / 18 / 83$ & $10: 00$ & $76^{c}$ & 38 & $23^{2}$ & -16 & -5 & 123 & $47^{6}$ & 66 \\
\hline $7 / 20 / 83$ & $10: 00$ & $70^{c}$ & 38 & $24^{2}$ & -16 & -5 & 121 & $46^{2}$ & 67 \\
\hline (T) & & & p & & & & & & \\
\hline $8 / 9 / 83$ & $8: 00$ & 102 & 38 & 22 & -17 & 0 & 95 & 56 & 59 \\
\hline & $9: 40$ & 101 & 38 & 22 & -16 & 0 & 95 & 56 & 59 \\
\hline & $11: 00$ & 103 & 38 & 22 & -18 & 0 & 94 & 56 & 59 \\
\hline & $12: 00$ & 108 & 38 & 24 & -18 & 0 & 95 & 58 & 60 \\
\hline & $12: 40$ & 111 & 38 & 26 & -16 & 0 & 98 & 59 & 64 \\
\hline & $15: 20$ & 112 & 38 & 30 & -18 & 0 & 100 & 61 & 69 \\
\hline & $17: 30$ & 113 & 38 & 33 & -18 & 0 & 104 & 62 & 71 \\
\hline $8 / 10 / 83$ & $8: 30$ & 111 & 36 & 30 & -18 & $\overline{\text { neg }}$ & 104 & 62 & 71 \\
\hline & $11: 20$ & 115 & 38 & 32 & -17 & neg. & 105 & 63 & 72 \\
\hline & $13: 40$ & 116 & 39 & 36 & -17 & 0 & 108 & 63 & 71 \\
\hline & $15: 30$ & 117 & 40 & 38 & -17 & 18 & 111 & 64 & 70 \\
\hline & $17: 30$ & 116 & 40 & 40 & -17 & 32 & 118 & 64 & 69 \\
\hline $8 / 11 / 83$ & $9: 20$ & 113 & 38 & 39 & -16 & 32 & 120 & 62 & 66 \\
\hline $8 / 15 / 83$ & $10: 00$ & 110 & 38 & 40 & -16 & 29 & 110 & 59 & 65 \\
\hline $8 / 17 / 83$ & $10: 00$ & 110 & 38 & 40 & -16 & 29 & 106 & 59 & 62 \\
\hline $8 / 19 / 83$ & $10: 00$ & 109 & 38 & 40 & .16 & 28 & 105 & 58 & 62 \\
\hline $8 / 22 / 83$ & $10: 00$ & 108 & 38 & 39 & -16 & 27 & 102 & 56 & 62 \\
\hline$f_{1}$ & & & & & $\%$ & & & & \\
\hline $10 / 25 / 83$ & $8: 00$ & 2 & 17 & 17 & 0 & 0 & 46 & 0 & 33 \\
\hline & $12: 30$ & 3 & 19 & 16 & 0 & 0 & 48 & 0 & 33 \\
\hline & $14: 10$ & 5 & 20 & 20 & 0 & 0 & 54 & 0 & 36 \\
\hline & $16: 00$ & 5 & 21 & 20 & 0 & 0 & 59 & 0 & 39 \\
\hline $10 / 26 / 83$ & $8: 00$ & 4 & 20 & 20 & 0 & 0 & 66 & $\overline{0}$ & 42 \\
\hline & $11: 20$ & 5 & 22 & 21 & 0 & 0 & 75 & 0 & 44 \\
\hline & 13:00 & 7 & 22 & 24 & 0 & 8 & 77 & 0 & 46 \\
\hline & 15:00 & 8 & 23 & 24 & 0 & 8 & 77 & 1 & 46 \\
\hline & $17: 00$ & 6 & 27 & 26 & 0 & 9 & 77 & 4 & 48 \\
\hline & $18: 00$ & 7 & 28 & 26 & 0 & 12 & 78 & 5 & 52 \\
\hline & $18: 45$ & 6 & 28 & 26 & 0 & 10 & 83 & 4 & 52 \\
\hline $10 / 31 / 83$ & $10: 00$ & & 39 & 25 & 0 & 24 & 93 & & 52 \\
\hline $11 / 10 / 83$ & \begin{tabular}{l|}
$10: 00$ \\
\end{tabular} & a & 41 & 25 & 0 & 37 & 93 & J & 51 \\
\hline $11 / 15 / 83$ & $10: 00$ & a & 42 & 26 & 0 & 38 & 82 & 8 & 50 \\
\hline $11 / 18 / 83$ & $10: 00$ & & 42 & 25 & 0 & 39 & 91 & & 49 \\
\hline
\end{tabular}


Table 2.6. Rock cover well pressure tests conducted at NHF (cont.)

\begin{tabular}{|c|c|c|c|c|c|c|c|c|c|}
\hline \multirow[b]{2}{*}{ Date } & \multirow[b]{2}{*}{ Time } & \multicolumn{8}{|c|}{ Pressure (psig) } \\
\hline & & $\begin{array}{c}1971 \\
\text { (4N-200RC) }\end{array}$ & $\begin{array}{c}1973 \\
(4 \mathrm{NE}-280 \mathrm{RC})\end{array}$ & $\begin{array}{c}1969 \\
(4 \mathrm{E}-200 \mathrm{RC})\end{array}$ & $\begin{array}{c}1979 \\
\text { (4SE-280RC) }\end{array}$ & $\begin{array}{c}1976 \\
\text { (4S-200RC) }\end{array}$ & $\begin{array}{c}1980 \\
(4 S W-280 \mathrm{RC})\end{array}$ & $\begin{array}{c}1981 \\
(4 \mathrm{~W}-190 \mathrm{RC})\end{array}$ & $\begin{array}{c}1974 \\
\text { (4NW-340RC) }\end{array}$ \\
\hline \multicolumn{10}{|c|}{ 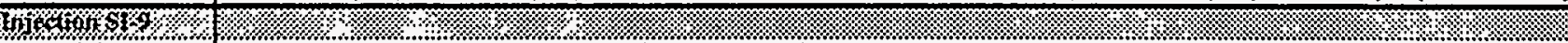 } \\
\hline \multirow[t]{7}{*}{$12 / 1 / 83$} & $8: 00$ & 10 & 41 & 25 & 0 & 32 & 64 & 2 & 46 \\
\hline & $8: 00$ & 10 & 41 & 25 & 0 & 35 & 79 & 2 & 49 \\
\hline & $10: 15$ & 5 & 42 & 29 & 1 & 40 & 83 & 4 & 50 \\
\hline & $12: 15$ & 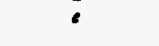 & 42 & 29 & 1 & 40 & 85 & 2 & 52 \\
\hline & $14: 15$ & e & 42 & 34 & 1 & 37 & 97 & 1 & 63 \\
\hline & $16: 15$ & 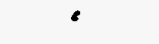 & 41 & 33 & 1 & 35 & 110 & 0 & 73 \\
\hline & $18: 00$ & 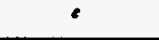 & 40 & 33 & 0 & 35 & 117 & 0 & 80 \\
\hline \multirow[t]{4}{*}{$12 / 2 / 83$} & $8: 00$ & 7 & 40 & $\overline{32}$ & 0 & 35 & 149 & 0 & 80 \\
\hline & $11: 00$ & e & 37 & 32 & 1 & 37 & $130^{\circ}$ & 0 & 80 \\
\hline & $13: 30$ & e & $35^{\circ}$ & 38 & 0 & 44 & $140^{\prime}$ & 0 & 80 \\
\hline & $15: 30$ & $\varepsilon$ & 34 & 42 & 0 & 50 & $143^{\prime}$ & 0 & 80 \\
\hline $12 / 5 / 83$ & $10: 00$ & $\overline{6}$ & 32 & 40 & 0 & 53 & $0^{5}$ & 0 & 75 \\
\hline $12 / 8 / 83$ & $10: 00$ & & 33 & 38 & $T$ & 33 & $0^{5}$ & 0 & $\pi$ \\
\hline
\end{tabular}

Compiled from: Tiegs 1983a through 1984c and Weeren 1984a through 1984e.

Note: a Wellhead was reported to be leaking around sonic probe.
b. Wellheads were opened to remove sonic probes.
c. A visible leak of the wellhead was observed.
d. Wellheads were left uncapped.
e. Wellhead leak observed.
f. Wellhead frozen.
g. Welhead left uncapped. 
Table 2.7. Water acceptance tests conducted at the New Hydrofracture Facility

\begin{tabular}{|c|c|c|c|c|c|c|c|}
\hline \multirow{3}{*}{$\begin{array}{l}\text { Well } \\
\text { ID }\end{array}$} & \multirow{3}{*}{$\begin{array}{l}\text { Well } \\
\text { Alias }\end{array}$} & \multicolumn{6}{|c|}{ Volume of water accepted $\left(\mathrm{cm}^{3}\right)$} \\
\hline & & \multicolumn{2}{|c|}{ June $1982^{a}$} & \multicolumn{2}{|c|}{ December $1982^{b}$} & \multicolumn{2}{|c|}{ July $1983^{c}$} \\
\hline & & 1 hour & 2 hour & 1 hour & 2 hour & 1 hour & 2 hour \\
\hline 1971 & $4 \mathrm{~N}-200 \mathrm{RC}$ & 410 & 240 & 20 & 60 & 0 & 0 \\
\hline 1973 & 4NE-280RC & 395 & 250 & 170 & 190 & 140 & 115 \\
\hline 1969 & $4.000000 \mathrm{e}-200$ & 1800 & 1050 & 1730 & 1810 & 1520 & 1000 \\
\hline 1979 & 4SE-280RC & 605 & 715 & 650 & 550 & 800 & 510 \\
\hline 1976 & 4S-200RC & 140 & 140 & 220 & 150 & 350 & 270 \\
\hline 1980 & 4SW-280RC & 1100 & 970 & 110 & 90 & 0 & 0 \\
\hline 1981 & $4 \mathrm{~W}-190 \mathrm{RC}$ & 420 & 380 & 300 & 200 & 180 & 130 \\
\hline 1974 & $4 \mathrm{NW}-340 \mathrm{RC}$ & 4700 & 3350 & 2550 & 2040 & 650 & 555 \\
\hline
\end{tabular}

Compiled from: Weeren $1984 \mathrm{~g}$.

'The water acceptance tests were conducted prior to operations at the New Hydrofracture Facility.

'The water acceptance tests were conducted after injections ILW-19, SI-1, SI-2, and SI-3.

'The water acceptance tests were conducted after SI-4, SI-5, ILW-20, and SI-6. 


\section{REMEDIAL SITE EVALUATION}

The NHF wells were evaluated to provide background information to support P\&A or temporary monitoring recommendations. One of the primary drivers for remedial evaluation activities at the NHF was the discovery of the potential for migration of radioactive contaminants at OHF and the poor condition of many wells at that site. The field activities involved tapping potentially pressurized wells, sampling and analyzing wellbore water, and obtaining geophysical logs from each well to evaluate contamination, well construction, and well integrity. The field effort began in June 1995 and concluded in December 1995. Volume 2 of this report provides a detailed description of the field activities.

A pressure-conservative drilling apparatus was used to gain initial access to the wellheads because many of the wells are open to formations exhibiting artesian pressures. A tapped well not under pressure remained vented for several days so the water level could be observed and measured. Wells under pressure were kept shut-in, and a pressure gauge was attached to the wellhead to monitor the pressure inside the wellbore.

The standing water column in the wells was grab sampled at three depths to provide contaminant data to support the waste management and health and safety concerns regarding geophysical logging and potential P\&A efforts. It was not possible to obtain data of sufficient quality to support RCRA or CERCLA groundwater compliance monitoring requirements because of the uncertain construction and/or condition of the rock cover, observation, and deep monitoring wells. Before Wells 2373 (DM1-RM), 2374 (DM2-RM), 2375 (DM3A-PV), 2952 (DM1-RT), and 2953 (DM3-RT) could be sampled or logged, $27 \%$ in.-ID carbon steel tubing, packers, and pressure transducers had to be removed from each. The temperature logs were run in the wells shortly after the tubing and packer removal operation. The temperature traces in some cases are erratic indicating that the temperature had not stabilized in the well(s). At the end of the investigation, all NHF wellheads were modified to allow future access.

The water column was sampled near the top, bottom, and middle using a special sampling device to obtain water samples at depth. All of the wells were sampled except for observation Well 1970 (4E-200W), which was constructed with nonstandard 1.25-in.-ID tubing. The smaller-diameter tubing did not allow the sampler or the borehole geophysical logging probes to fit into the well. While attempting to collect the bottom sample from Well 1977 (4S-200W), the sampler was blocked by an obstruction in the well casing at a depth of $483 \mathrm{ft}$ bgs. The geophysical logging was not affected by the obstruction, however, and the well was logged to total depth.

To minimize waste generation, the wells were not purged before the 1995 sampling. There is no record of the observation wells having been previously purged; however, the rock cover and DM wells were purged in 1986. Because the wells had not been recently purged, the water data may not be representative of in situ formation water. Deep water samples were not collected using a pressureconservative sampler; therefore, off-gassing and precipitation reactions may have altered ionic chemistry and $\mathrm{pH}$. Analysis for selected cations, anions, radionuclides, and organics was performed on the wellbore water (60 samples from 20 wells) at Environmental Restoration's Close Support Laboratory (CSL).

Geophysical logging was performed in each NHF well except for 1970 (4E-200W) (nonstandard small diameter tubing) and 1972 (4N-200W) by the ORNL Geology, Geophysics, and Geochemistry Group. The logging probes could not fit into Well 1972 because the well riser is bent

near the ground surface and restricts access to the well. All logging proceeded from the least to the most contaminated wells based on the wellbore water analytical results. 



\section{HYDROGEOLOGIC SETTING}

\subsection{REGIONAL GEOLOGY}

The Oak Ridge Reservation (ORR) is situated in the Valley and Ridge Province, which is part of the Southern Appalachian fold-and-thrust belt. The area is characterized by a succession of southwest- to northeast-trending thrust faults that duplicate the Paleozoic-age sedimentary rock sequences. Because of the thrusting, differential erosion has resulted in a series of alternating valleys and ridges that parallel the surface traces of the thrust faults. Rocks resistant to weathering (sandstones and dolomite or chert units) generally form the ridges, whereas rocks that are more readily weathered (shales and shaley carbonates) typically underlie the valley floors.

Four major formations occur in the ORR. The following is a list in order from the oldest to youngest unit:

- Rome Formation (composed of shale, siltstone, and sandstone);

- Conasauga Group (shale, siltstone, and limestone);

- Knox Group (dolomite and limestone); and

- Chickamauga Group (limestone with some interbedded shale).

Thrust faulting in the general vicinity of the ORR has resulted in the lower Cambrian Rome Formation juxtaposed on the middle Ordovician Chickamauga Group.

Regional strike of strata in the ORR portion of the Valley and Ridge Province is $N 50^{\circ}$ to $60^{\circ} \mathrm{E}$, and the dip of rocks at the surface is $25^{\circ}$ to $55^{\circ}$ to the southeast. At depth, the dip decreases to nearly horizontal, and the thrust faults become nearly horizontal to form essentially bedding-parallel faults. Horizontal displacement along a major thrust fault can be as great as 30 to 60 miles (Roeder, Gilbert, and Witherspoon 1978). Local fault displacements are estimated to be somewhat less, on the order of 6 to 9 miles. Within the sediments of the imbricate thrust sheets, a large number of small-scale folds and fractures have formed, resulting in a complex structural fabric.

\subsection{SITE GEOLOGY}

Haase (1983; 1985), Haase, Switek, and Stow (1985), and Hatcher et al. (1992) discuss the site geology. Much of the recent published geologic information on the stratigraphy and structure of Melton Valley has been directed toward the hydrofracture area. In the following discussion, emphasis is placed on the disposal (injection) formation, the upper Pumpkin Valley Shale.

Figure 4.1 illustrates the generalized geohydrologic map for the ORR area and the NHF region. Figure 4.2 is a generalized geologic map and cross section showing the location of OHF and NHF and formations penetrated by specific types of wells. Observation wells such as Well 1972 penetrate the injection horizon in the Pumpkin Valley Shale. Rock cover wells such as Well 1976 are completed in the Rogersville Shale and/or Rutledge Limestone and were used to monitor injection pressures and "permeability" changes in the overlying "rock cover" formations. 
At the hydrofracture sites, the stratigraphic sequence in the basal portion of the Copper Creek thrust fault block consists of (from bottom to top), the Rome Formation; the Conasauga Group, which includes the disposal (injection) formation (upper and lower Pumpkin Valley Shale); and the Knox Group (Fig. 4.3). The Rome Formation is 300 to $500 \mathrm{ft}$ thick and consists of massive sandstones, thinly bedded siltstones, and laminated shales and mudstones. The Conasauga Group is 1800 to $2000 \mathrm{ft}$ thick and consists of six formations. In ascending order, they are, the (upper and lower) Pumpkin Valley Shale, Rutledge Limestone, Rogersville Shale, (upper and lower) Maryville Limestone, Nolichucky Shale, and Maynardville Limestone.

The clastic-rich formations, including the Pumpkin Valley Shale, consist of thinly bedded siltstones and laminated shales and mudstones. The carbonate-rich formations consist of coarse to fine-grained limestones, conglomerates, and calcareous siltstones and shales. The Knox Group consists of chert-rich carbonates, principally massive dolostone with subordinate amounts of limestone, and locally abundant sandstones. Near the ORNL site, the Knox Group has been divided into five formations (Mascot Dolomite, Kingsport Formation, Longview Dolomite, Chepultepec Dolomite, and Copper Ridge Dolomite) that range from 2000 to $2200 \mathrm{ft}$ in thickness (Milici 1973).

The structural fabric of strata at the base of the Copper Creek thrust sheet is characterized by

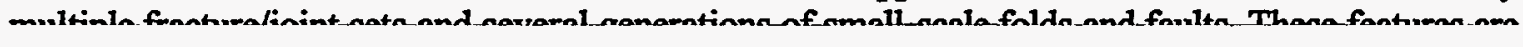

\section{4-4}

After dissipation of the induced pressure, the regional hydrogeologic flow regime would once again dominate. This flow regime near NHF, however, would have been altered by the opening of fresh pathways (induced fractures, microfractures, and boreholes). Aqueous radionuclides would be transported with groundwater through and along these migration pathways.

\subsection{GROUNDWATER HYDROLOGY}

\subsubsection{Regional Characteristics}

There are few meaningful data describing regional groundwater flow within the ORR Mechanisms and rates of flow appear to be controlled by topography, lithology, and structure. Two deep monitoring wells (2372 and 2374) are presently developed in the Rome Formation near the NHF site. Because of the highly variable lithology of the Conasauga Group, groundwater conditions also vary. In the carbonate-rich formations, groundwater may move along small solution cavities and fractures; in the more shale-rich lithologies, movement is almost solely along fractures.

\subsubsection{Site Characteristics}

There are little data describing deep groundwaters at the hydrofracture sites. Although many wells and coreholes have been drilled over the last three decades, only recently have groundwater wells been constructed for hydrologic data acquisition.

Permeability data for the strata at depths similar to the injection zone are sparse. De Laguna et al. (1968 and unpublished data) reported low laboratory permeability measurements on the order of $10^{-5}$ millidarcies (md) for drill core of the Pumpkin Valley Shale. Observed rates of recovery of wells recently drilled to the injection interval also indicate low permeability. The impact of the hydrofracture injection activities on the hydraulic characteristics of the strata is presently unknown. 
of initial well tapping. After sampling and logging, Wells 2954 and 2955 have recharged and are once again pressurized. In addition to these two wells, Well 1982 has become pressurized. When Well 1982 was initially tapped, a water level of $10.61 \mathrm{ft}$ bgs was recorded. By December 7, 1995, a shut-in pressure reading of $113 \mathrm{psig}$ was measured. This is approximately equivalent to $261 \mathrm{ft}$ of water column head.

Wells 1970 and 1982 are cased (probably breached) observation wells. The remaining four $(2372,2375,2954$, and 2955) are deep monitoring wells. Well 2373 has an open hole interval in the Rome Formation, whereas Wells 2373, 2954, and 2955 are open in the Pumpkin Valley Shale. The total head measurements are presented on Fig. 4.5, and the water level and pressure measurements for each individual well have been included in Volume 2. At times, the hydraulic head in these wells would exceed the ground surface, resulting in probable flowing artesian conditions. These results would confirm artesian conditions produced by topographic and structural controls.

The deep monitoring well cluster, which is located approximately $1,000 \mathrm{ft}$ east of the NHF, consists of three wells (2373, 2952, and 2954), open to three different formations (Rome Formation, Rutledge Limestone, and Pumpkin Valley Shale, respectively). Head measurements made in the three wells indicate an upward gradient from the Pumpkin Valley Shale to the Rutledge Limestone (Fig. 4.6).

Recent unpublished hydraulic head data derived from Westbay ${ }^{\mathrm{TM}}$ multiport pressure monitoring systems installed in Wells 4010, 4011, and 4012 (HHMS-12, -13, and -14 , respectively), generally updip and approximately $3,300 \mathrm{ft}$ north of the NHF, indicate that pressurized conditions exist in the lower interval of the Rome Formation (personal communication from RaNaye Dreier, ORNL). Westbay ${ }^{\mathrm{TM}}$ measurement ports open to the brecciated lower Rome Formation interval exhibit elevated hydraulic heads at a depth of approximately $300 \mathrm{ft}$ bgs. The hydraulic head rapidly attenuates within the overlying upper interval of the Rome Formation and Pumpkin Valley Shale and the underlying Chickamauga Group formations. The system, which is topographically and structurally controlled, creates a "confined artesian interval."

Changes in hydraulic head(s) within Wells 4010, 4011, and 4012 correlate with seasonal precipitation, indicating hydraulic connection with the Haw Ridge recharge area. Flowing artesian conditions, observed during drilling of OHF injection Well 1944 (personal communication from H. O. Weeren, December 1993), were most likely related to the upward gradient that is measured updip from the injection zone.

A multiport Westbay ${ }^{\mathrm{TM}}$ pressure monitoring system has been installed in artesian Well 1953 at OHF. This well, located approximately $800 \mathrm{ft}$ updip from NHF, has a long open hole through the Rogersville Shale into the lower Pumpkin Valley Shale. Resent unpublished hydraulic head data (provided by RaNaye Dreier, ORNL, and A. J. Caldanaro, University of Tennessee) are shown on Fig. 4.7. These data also indicate an upward gradient from the Pumpkin Valley Shale.

Flow within the shallow groundwater system is generally limited to the uppermost $100 \mathrm{ft}$ of saturated regolith, saprolite, and bedrock. Approximately 30 percent of the total discharge occurs within the stormflow zone, which consists of permeable soil due to secondary root tube porosity (BEI 1995). Potentiometric surface maps for both high (March 23-25, 1993) and low (August 29-30, 1993) precipitation periods indicate that horizontal flow in the shallow groundwater system is generally toward discharge to White Oak Creek and Melton Branch. 


\subsection{GROUNDWATER GEOCHEMISTRY}

NHF WAG 10 groundwater was geochemically evaluated to provide screening level to:

- support geophysical logging of the wells for evaluation of the wellbore integrity, and

- determine the types of waste expected to be generated during potential P\&A operations.

The evaluation was based on concentration data for major anions and cations. Complete geochemical interpretation would require a large number of chemical analyses carried out on high-quality water samples taken from a representative set of wells in an area. Groundwater samples collected from NHF wells were grab samples that were analyzed by a CSL. These wells were not purged prior to sampling, and are, therefore, not representative of formation water.

All of the 21 wells associated with NHF are cased to a minimum depth of $480 \mathrm{ft}$, isolating (casing off) the Nolichucky Shale, (upper and lower) Maryville Limestone, and a significant portion of the Rogersville Shale formation. The six observation wells are cased to total depth; they were used during facility operations for the purpose of periodic passive gamma ray logging to monitor grout sheets during injection activities. The geochemical results from the observation wells do not represent native groundwater. These chemical results, however, were useful for planning of borehole logging (presence, concentration, and type of contamination) and aiding in the interpretation of casing integrity.

A Piper diagram illustrating the groundwater geochemistry for the top, middle, and bottom samples was constructed using mean values for the three well types (cased observation, rock cover, and deep monitoring) (Fig. 4.8). Data collected from historical water sampling of the deep monitoring and rock cover wells performed in 1983, 1985, and 1986 by ORNL are also plotted on this figure for comparison with the 1995 sampling data. All of the wells were purged prior to the ORNL 1986 sampling.

Water sampled from the cased observation wells has a sodium/calcium bicarbonate composition. Results from the other two well types, however, show that the data points are closely clustered and the water in all cases is of sodium chloride composition. The major ions are sodium, calcium, and chloride. No ion crossplots were constructed for the observation wells. This water is distinct from the sodium chloride rock cover/deep monitoring water and is not representative of the natural geochemical system. The observation well water's $\mathrm{pH}$ is basic at $10.5 \pm 1.6$, with a range from 8.69 to 12.57 (Table 4.1 and Fig. 4.9). TDS concentrations range from a low of $133 \mathrm{mg} / \mathrm{L}$ to a high of approximately $90,000 \mathrm{mg} / \mathrm{L}$ but are generally in the fresh to brackish range (100 to $2,000 \mathrm{mg} / \mathrm{L}$ ).

Observation wells with low TDS and high $\mathrm{pH}$ values suggest that the well casing is possibly intact and not open (breached) to the surrounding groundwater. The water present in the borehole is likely a remnant of well installation activities and grout injection monitoring. When observation well casing integrity is compromised at depth, however, the influx of deeper native briny groundwater would tend to substantially elevate TDS/conductivity by several orders of magnitude and may reduce the $\mathrm{pH}$ value. In contrast, contaminated grout filtrate would tend to slightly increase the TDS (by addition) and, therefore, increase the conductivity, and also elevate the $\mathrm{pH}$ due to reaction with grout. The higher TDS concentrations and very basic pHs, measured in the bottom sample from Wells 1975, 1978, and 1982 compared to other samples collected from the observation wells, would indicate influx of grout filtrate to the wellbore. 
This conclusion is supported by comparing TDS and pH values to those of the rock cover and deep monitoring wells. The $\mathrm{pH}$ in the bottom samples from observation Wells 1975, 1978, and $1982-12.57,12.29$, and 11.86 respectively-is generally more basic than any of the other wells (Table 4.1 and Fig. 4.9). The TDS of these wells-89,927, 20,139 and $1646 \mathrm{mg} / \mathrm{L}$ respectively-is also lower than both the rock cover and deep monitoring wells (except geologically updip Well 2375). The bottom samples in observation Wells 1975, 1978, and 1982 are contaminated with radionuclides $\left({ }^{3},{ }^{60} \mathrm{Co},{ }^{137} \mathrm{Cs}\right.$, and ${ }^{90} \mathrm{Sr}$ ) and nitrate. These results would support loss of casing integrity (probably caused by uplift due to grout injection) and influx of contaminated grout filtrate from NHF injections.

The rock cover wells were sampled several times after cessation of operations at the NHF facility. There is no record, however, of any sampling of these wells before or during injection operations. Therefore, it is impossible to evaluate the results against "background" sampling analytical results.

Water sampled and analyzed from the rock cover wells, as part of the 1995 investigation, is of a sodium chloride composition. The major ionic constituents are sodium with lesser amounts of calcium and chloride (Fig. 4.8). The table included with Fig. 4.8 gives ionic results for maximum, minimum, and mean concentrations of major ions for WAG $10 \mathrm{NHF}$ rock cover (open interval, 0 to $700 \mathrm{ft}$ ) wells. These wells were purged prior to the 1986 sampling conducted by ORNL but were not purged for the 1995 sampling event. Obviously, the presence of an open interval plays a significant role in the geochemistry of the rock cover well water because of influx of water from the exposed formation. In the case of the rock cover wells, this is the Rogersville Shale and/or Rutledge Limestone.

Typically, the rock cover wells are characterized by acidic pH levels (5.04 to 7.46) and high TDS/high conductivity briny water (minimum of 45,092 and maximum of $246,504 \mathrm{mg} / \mathrm{L}$ TDS) (Fig.4.6). The average TDS for all three samples collected from each rock cover well is 161,768 \pm $49,949 \mathrm{mg} / \mathrm{L}$. In general, TDS does not appear to be stratified in the wells (Table 4.1 and Fig. 4.9). Casing integrity appears to be good (good isolation) and fresh water from the overlying strata (primarily upper Maryville Limestone) has not entered the wellbore to dilute the water.

The ratios of $\mathrm{Na}: \mathrm{Cl}, \mathrm{Ca}: \mathrm{Cl}$, and $\mathrm{Br}: \mathrm{Cl}$, and the relationship of TDS versus specific conductance are shown in Fig. 4.10. All of the data sets show a good correlation. The ratio of $\mathrm{Na}: \mathrm{Cl}$ for the rock cover wells is 0.67 , which is less than the 0.86 current ratio for meteoric water. The ratio, however, is within the range ( 0.6 to 0.7$)$ for brines in surrounding states that have abundant salt (halite) beds and would be expected for water where sodium is depleted due to halite precipitation (Nativ and Hunley 1993). The $\mathrm{Br}: \mathrm{Cl}$ ratio is 0.008 , somewhat higher than the marine value (0.002), and may also suggest slight bromide enrichment due to halite precipitation.

The plot of specific conductance (field measured) versus TDS (CSL measured) is presented in Fig. 4.10. This plot was constructed to provide an aid for estimating TDS in the field based on specific conductance and borehole log resistivity measurements.

Nitrate was not detected in the water sampled in any of the rock cover wells (Table 4.2), indicating that contamination with radionuclides representative of the injected grout is minimal (Table 4.3). The results suggest the injected grout wastes have had a minimal impact on the rock cover (Rutledge Limestone). The source of the radionuclides present could be from very minor upward migration from the grout sheets or lateral migration from the injection well (Switek 1987). Cross-contamination is also a possible contributor of minor radiological contamination in these wells. 
The deep monitoring wells were installed to monitor the injection horizon after completion of operations at NHF: two of the wells (2952 and 2953) have openhole intervals in the Rutledge Limestone, three $(2375,2954$, and 2955$)$ have openhole intervals in the injection horizon, and two (2373 and 2374) have openhole intervals in the underlying Rome Formation. Two sets of wells are clustered: east of NHF, Wells 2373, 2952, and 2954; and west of NHF, Wells 2955 and 2374. The two remaining wells (2375 and 2953) are generally updip of NHF. The distribution of these wells is shown in Figs. 2.1 and 2.2.

All of the water sampled from the deep monitoring wells is of a sodium chloride composition (Fig. 4.8 and Table 4.2). The $\mathrm{pH}$ is variable (from 7.59 \pm 1.6 ) and, when compared to that measured in the rock cover wells, tends to be more basic (Fig. 4.9). The TDS values (excluding Well 2375) indicate brine $(191,565 \pm 69,440)$. Well 2375 , which has a TDS content of $35,422 \mathrm{mg} / \mathrm{L}$ (similar to sea water), is anomalous when compared to these wells and the rock cover wells in the NHF area. Well 2375 also has a high sulfate content ( 602 to $1070 \mathrm{mg} / \mathrm{L}$ ).

In general, TDS does not appear to be stratified (Table 4.1 and Fig. 4.9), except possibly in wells 2374 and 2952. In these two wells, the top samples are of lower TDS (104,931 and 15,402 $\mathrm{mg} / \mathrm{L}$ respectively) when compared to the deeper samples $(>270,000$ and $>150,000 \mathrm{mg} / \mathrm{L}$ TDS, respectively). Casing integrity may be poor in these two wells. In the other five wells, based on chemistry, casing integrity appears to be good (good isolation) because fresh water from the overlying strata (primarily Nolichucky Shale, Maryville Limestone, and Rogersville Shale) does not appear to have entered the wellbore and diluted the water (decreased the TDS).

The ratios of $\mathrm{Na}: \mathrm{Cl}, \mathrm{Ca}: \mathrm{Cl}$, and $\mathrm{Br}: \mathrm{Cl}$, and the relationship of TDS versus specific conductance are shown in Fig. 4.11. All of the data sets show a good correlation. The ratio of $\mathrm{Na}: \mathrm{Cl}$ for the deep monitoring wells is 0.67 , which is similar to the rock cover wells. This ratio is less than meteoric water (0.86), but within the range $(0.6$ to 0.7$)$ for brines that are depleted due to salt precipitation. The $\mathrm{Br}: \mathrm{Cl}$ ratio is 0.009 , somewhat higher than the marine value $(0.002)$, and may also suggest slight bromide enrichment due to halite precipitation.

Three deep monitoring wells were initially drilled to monitor the injection horizon after shutdown of operations at NHF (Wells 2373, 2374, and 2375). Shortly after installation in September of 1984, it was discovered that groundwater in Wells 2373 and 2374 is contaminated with radionuclides $\left({ }^{60} \mathrm{Co},{ }^{137} \mathrm{Cs}\right.$, ${ }^{90} \mathrm{Sr}$, and short-lived $\left.{ }^{106} \mathrm{Ru}\right)$ and nitrate sourced from the grout sheets (Tables 4.4 through 4.6).

After this discovery, all three wells were recompleted by shortening the openhole interval to monitor specific zones [Rome Formation (2373 and 2374) and Pumpkin Valley Shale (2375)]. Four additional wells were also installed: $2952,2953,2954$, and 2955 . Results of the present sampling indicate significant radiological contamination in "new" Pumpkin Valley Wells 2954 and 2955. These results also indicate radiological contamination in the recompleted Rome Formation wells (2373 and 2374). Contamination in the Rutledge Limestone wells (2952 and 2953) is minimal. The radiological contamination in the Pumpkin Valley Shale is sourced from the grout sheets. It is believed that contamination in the Rome Formation is a "remnant" cross-contamination from when the well had a long openhole interval through the injection horizon into the Rome Formation.

As groundwater moves through the subsurface flow system it typically undergoes a geochemical evolution. Generally, salinity (as reflected by increased TDS/conductivity) will increase along the flow path(s) (i.e., water from a recharge area is usually relatively fresh, and water from discharge areas is often relatively saline). The analytical results from the 21 wells around NHF showed minimal variation in TDS concentrations from similar well types of similar formation and 
depth. Typically, rock cover wells that are cased to approximately $500 \mathrm{ft}$, deepened, and left open to $600 \mathrm{ft}$, have briny borehole water (generally TDS $>150,000 \mathrm{mg} / \mathrm{L}$ ) throughout the water column. Deep monitoring wells, which are cased to the top of the monitoring horizon or were constructed with an open interval within the injection zone, also exhibit briny conditions throughout the water column (TDS $>150,000 \mathrm{mg} / \mathrm{L}$ ).

The bottom samples in observation Wells 1975, 1978, and 1982 are contaminated with radionuclides $\left(\mathrm{H},{ }^{60} \mathrm{Co},{ }^{137} \mathrm{Cs}\right.$, and ${ }^{90} \mathrm{Sr}$ ) and nitrate caused by influx into the borehole of contaminated grout/filtrate from NHF injections. Results also suggest the injected grout wastes and filtrate have had a minimal impact on the groundwater in the rock cover (Rogersville Shale/Rutledge Limestone). Radiological contamination, sourced from the grout sheets, of the groundwater within the Pumpkin Valley Shale (injection horizon) is very significant. It is believed that contamination in the Rome Formation is a "remnant" from when the well had a long openhole interval through the injection horizon into the Rome Formation.

\subsection{CONCEPTUAL MODEL}

The conceptual model developed for the NHF area is based on interpretation and evaluation of the subsurface geology and area groundwater hydrology, plant operational reports/records, historical analytical and borehole geophysical data, and recently collected analytical and borehole geophysical data. The approach taken was to discuss potential exposure mechanisms, followed by

- operating conditions and monitoring activities during NHF operations, and

- contaminant distribution.

The section is closed with a summary of the spatial distribution of contaminants.

\subsubsection{Potential Exposure and Transport Mechanisms and Pathways}

This section discusses the possible mechanisms by which contamination sourced from injected grout could migrate along potential exposure pathways. The discussion of hydrogeologic transport outside the wellbores is somewhat speculative because the sampling plan was not designed to collect data to directly address hydrologic conditions and contaminant migration through the pore network of the rock/rock matrix. The discussion, however, is included to provide some insight into possible mechanisms that might account for the observed patterns in the wellbore data.

Aqueous and particulate radioactive contaminants were introduced into the subsurface by hydrofracture operations conducted at NHF. The possible mechanisms that could result in radionuclide release are

- part of the hydrofracture operations processes,

- leaching of contaminants from the emplaced grout,

- incomplete mixing of the grout,

- phase separation water (grout filtrate) released during grout setup due primarily to injection of grout having the improper mix ratio, and/or

- lead water used to initiate fracture or follow-up water used to wash out injection system. 
The driving mechanism for possible migration of aqueous contaminants, during the initial stages of injection and shortly after the total slug of contaminated grout has been injected, would be primarily artificially induced pressure. The induced pressure regime would, for a time, dominate the ambient head distribution and alter the normal flow system. Contaminated grout would be expected to primarily remain within the induced fracture(s). Some of the grout, before setup, might also escape to cased and uncased boreholes that were in place before injection.

Grout filtrate (phase separation) will occur as the contaminated grout is injected and cures. The volume of grout filtrate separating will primarily depend on the mix ratio used for the injection. Chemically, the contaminated filtrate will mimic the injected grout. The dominant ions present will be similar to the deep brine. Initially and before equilibration with the geochemical system, the filtrate would have a basic $\mathrm{pH}$.

The filtrate would also contain other constituents of the grout; however, direct samples of the filtrate were not obtained, so it can only be assumed that the constituents identified in Table 2.1 were contained in the filtrate. The specific proportion of those constituents in the filtrate has not been determined but is likely to be different than in the original waste mix. These differences would be due to active chemical reactions and processes and differential sorption within the grout, fractures, rock matrix, and formation.

Some of the ions will diffuse into the pore system of the rock matrix as the filtrate migrates into and through the microfracture/fracture system. The rate at which contaminants transfer from the face of the fracture into the matrix will be dependent upon concentration gradient, diffusive crosssectional area, and molecular diffusion coefficient. The net effect of matrix diffusion would be to reduce contaminant mobility by movement into relatively "immobile" bound water within the matrix pore system. The amount of time that is necessary for the contaminant to move through the system would increase as the constituents move slowly out of the matrix back into the fracture when concentrations within the fracture are reduced (Solomon et al. 1992).

Open and effective, joints and fractures provide the most efficient natural flow path within the clastic and carbonate section underlying the hydrofracture facilities. Healed joints and fractures, while basically impermeable under undisturbed subsurface conditions, provide planes of weakness within the clastic section. When disturbed (such as by hydrofracturing) these planes of weakness could be reactivated and increase the effective fracture porosity/permeability, thereby increasing flow within the deep system.

As the leading edge of an artificially induced fracture develops and moves out from the point source into the formation, a network of leading-edge microfractures is also created in association with the major fracture. The induced microfracture system(s) would increase the total effective fracture porosity/permeability of the rock section.

The contaminated liquids could, under induced pressure, migrate along these planes of weakness (bedding planes and/or open fractures/joints) into formations overlying or underlying the injection horizon (Pumpkin Valley Shale). After dissipation of the induced pressure, the regional hydrogeologic flow regime would again dominate. The flow regime near NHF, however, was altered by the opening of fresh pathways (induced fractures, microfractures, and boreholes) and emplacement of grout. Depending on the geochemistry of the system, mineralogy of the formation(s), and chemical nature of the contaminant, aqueous radioactive contaminants would be transported with groundwater through and along these migration pathways. In some areas, where the fracture system is enhanced by folds and faults, contaminants could be expected to migrate upsection and possibly to surface discharge points. No natural surface discharge points, however, are known to exist. 
Contaminants could also move vertically in wellbores through annular or intrawell flow. Results from the recent borehole geophysical logging program identified numerous anomalies and poor casing integrity in a number of the wells. Many wells were interpreted to have poor construction grout bonding (voids and channeling) between the casing and the borehole wall. The combined effect of local hydrogeology, hydrofracturing operations, and poor well quality (construction) could be significant and may play a major role in transport of contaminants in the wellbore. The migration pathways discussed are shown in Fig. 4.12.

\subsubsection{NHF Operating Conditions}

One test and 13 production injections were performed at NHF (HF-4). The injection well (1968) casing was slotted at four discrete depths (Table 4.7), and the batch injections were conducted through the upper three slots. The initial batch injection (ILW-19) was initiated at a depth of 1,069 $\mathrm{ft}$ bgs, and the final injection (ILW-21) was at $990 \mathrm{ft}$ bgs. All 13 batch injections were within the Pumpkin Valley Shale.

Figure 4.13 illustrates subsurface grout injections at NHF. The pie charts depict the makeup of the waste by volume and waste composition. The bottom of the Rutledge Limestone and Pumpkin Valley Shale, slot depths, injected activity and volume, and NHF injection history are also included in the figure, which brings out several points:

- the activity of the radionuclides injected through the three slots is generally comparable,

- ${ }^{90} \mathrm{Sr}$ activity, for the total injection through a slot, is greater than ${ }^{137} \mathrm{Cs}$ for all injections,

- the activity of transuranics injected through the lower two slots is comparable; however, the activity of transuranics is much higher in the upper slot, and

- the total injected volume is lowest in the upper slot.

Figure 4.14 contrasts the grout injections conducted at NHF versus OHF. The setup is similar to the previous figure except that the slot depths are not shown. Several factors are brought out by the figure as follows:

- the volume of grout as a percentage of total volume was higher at $\mathrm{OHF}$;

- the injection depth is approximately $200 \mathrm{ft}$ deeper at NHF, but within the same stratiographic interval;

- $\quad{ }^{137} \mathrm{Cs}$ was the primary radionuclide injected at $\mathrm{OHF}$ versus ${ }^{90} \mathrm{Sr}$ at NHF; and

- transuranics were more abundant in the injections at NHF.

Because of the differences in physical and chemical makeup of the waste streams (IIW and SI), two methods were used to determine ideal waste/grout mix ratio at NHF. The mix ratio used for the ILW injections was determined in a fashion similar to that used at OHF. The mix ratio used for the SI injections was determined based primarily on the physical (apparent viscosity) properties of the resuspended tank sludge. A maximum and minimum range of mix ratio was set for the individual SI batch injections.

Figures 4.15 through 4.18 were constructed to aid in evaluation of the mix ratios and dominant radionuclide content of the individual waste batches. The $y$-axis is mix ratio in $\mathrm{lb} / \mathrm{g}$ (with error or range bars) and the $x$-axis labels specify the tank number and ratio of ${ }^{90} \mathrm{Sr}$ to ${ }^{137} \mathrm{Cs}$. A ratio greater 
than one would indicate that ${ }^{90} \mathrm{Sr}$ is the dominant radionuclide in the waste. These figures highlight several points concerning the injections conducted at NHF. They are as follows:

- ${ }^{90} \mathrm{Sr}$ is the dominant radionuclide contained in most of waste batches injected at NHF,

- ${ }^{137} \mathrm{Cs}$ was the dominant radionuclide in two ILW (-19 and -20$)$ injections,

- ${ }^{90} \mathrm{Sr}$ was dominant in injection ILW-21, which was reported to contain some SI waste,

- SI-1 is anomalous, when compared to the other injections, in that the dominant major radionuclide varies from ${ }^{90} \mathrm{Sr}$ to ${ }^{137} \mathrm{Cs}$,

- in general, the actual mix ratio for the individual waste batches was within the error or range of the desired mix ratio, and

- several low mix ratio batches were emplaced during an injection.

The volume of water recovered from the grout waste in the injection well following waste emplacement is referred to as "bleedback." The percent of bleedback water would possibly give an indication of excessive grout filtrate. The bleedback data collected for NHF and summarized in Table 4.7 imply that more bleedback occurred after the first seven injections.

Also included on Table 4.7 is an evaluation of low mix ratio as a percentage of injection batches. No direct correlation is apparent between bleedback and low mix ratio. It does appear, however, that in general the actual mix ratios used for the first four injections were low.

\subsubsection{NHF Operations Site Monitoring Activities}

Several primary methods were used to monitor subsurface conditions and the position of the grout sheets during NHF operations: pressure and water acceptance ("permeability") testing using the rock cover wells, passive gamma ray logging of the cased observation wells to locate grout sheets, and detailed civil survey of established benchmarks to evaluate uplift.

The rock cover wells were logically placed around the NHF injection well to monitor the injections: in a radial pattern, at known distances, and at approximately $45^{\circ}$ arcs. All of the rock cover wells have an approximate 100-ft openhole interval in the Rogersville Shale/Rutledge Limestone. The Rutledge Limestone caps the injection horizon.

These particular wells were used for pressure and water acceptance testing. They were topped off with water, shut in, and equipped with pressure gauges; the pressures were periodically recorded (Tiegs 1983a through 1984c and Weeren 1984a through 1984e). The results of the pressure monitoring are presented in Fig. 4.19. The charts are constructed with pressure along the $y$-axis and the month/year of the test along the $x$-axis. The individual injections are labeled along the secondary $x$-axis. The figure illustrates the following:

- rock cover wells to the west and north of the injection well display an increase in pressure that persists during NHF operations;

- the highest pressures were recorded in Well 1971 (north) and Well 1980 (southwest) of injection Well 1968;

- the pressure pattern displayed by Well 1973 (northeast of the injection well) is similar to the western wells, but the measured pressures are lower; 
- Wells 1969 and 1976, to the east and south, display negative pressures until resumption of injection (SI-4) activities after recovery of injection Well 1968; and

- during well recovery operations, the pressure decreased in the western wells and increased in the eastern wells (relaxation of overburden).

An increase in pressure, caused by compression of the overlying units and water, would be expected as the grout sheet passes under a well. A corresponding pressure decrease would be noted at locations where the grout has not passed under a rock cover well. Therefore, based on the pressure results, the grout sheets appear to have moved away from the injection well updip to the northwest and along regional strike. The higher pressures measured in Wells 1971 and 1980 may imply a dominant strike component of grout movement.

The three water acceptance tests utilizing the rock cover wells were run by topping off each well with water, shutting in, and pressurizing (75 psi) (Weeren 1984f). The volume of water accepted was measured and recorded twice (after $1 \mathrm{~h}$ and $2 \mathrm{~h}$ ) at each well. The tests were run prior to production operations (but after the test injection), after the first four injections (ILW-19, SI-1, SI-2, and SI-3), and after the next four injections (SI-4, SI-5, ILW-20, and SI-6) (Table 2.7). No other water acceptance test results were located.

A frequency plot (rose diagram) of the water acceptance test results was constructed to determine directional components. This approach was used because the rock cover wells are positioned in a radial pattern at approximately $45^{\circ}$ arcs from the injection well, which makes them suitable for this type of presentation. The volumetric results (2-h) were normalized before plotting.

Figure 4.20 shows the rose diagrams for the water acceptance tests. The size of an individual $45^{\circ}$ petal represents the percentage within that arc; larger petals would imply relatively "higher permeability" in that direction. The radial line bisecting a petal represents a specific rock cover well. The grid and north arrows are included to give a sense of direction. The center point on the rose represents the "injection well."

Prior to operations, most of the water was accepted by Well 1974, to the northwest of NHF. This trend would be generally perpendicular to regional strike (updip). Secondary, equivalent trends are noted to the east (Well 1969, oblique to strike) and southwest (Well 1980, parallel to strike). The trend changed to dominant northwest (Well 1974) and east (Well 1969) components after the first four injections. Following the eighth injection (SI-6) and injection well recovery, the dominant trend shifted to the east (1969), with bimodal secondary trends to the southeast (1979) and northwest (1974).

The water acceptance test results show some correspondence with the pressure test results. Pressure increases were noted in rock cover wells west of the injection well. There is a significant trend in this general direction. Pressure increases were noted in Wells 1969 and 1973 after the SI-6 injection. This trend may correlate to the shift to the east noted on the rose diagram.

In 1983, 75 benchmarks were established around the NHF facility to study uplift/subsidence patterns caused by grout injections. Two sets of data are presented for discussion: the first set of civil survey data, collected approximately 5 days after the SI-8 injection; and the second round, approximately 30 days after the SI-8 injection. Contour maps illustrating the uplift/subsidence patterns are presented on Fig. 2.4. The maximum amount of uplift measured was $>1$ in. within 200 $\mathrm{ft}$ of the injection well. The contour pattern indicates that the grout sheets primarily migrated to the 
northwest in the direction of least hydrostatic pressure. Again, these results show some correlation with the rock cover pressure and water acceptance tests.

Figure 4.21 illustrates the primary directions of grout sheet movement. Total gamma ray counts (in cps, recorded during the 1995 well logging) are shown along the $x$-axis. The elevations of the grout sheets recorded from gamma logs run during NHF operation are shown on the secondary $x$-axis (Tiegs 1983a through 1984c and Weeren 1984a through 1984e). No new logs could be run in Well 1970 (small diameter) or Well 1972 (bent riser). The results, with the exception of Well 1977, indicate primary grout movement to the west and east.

\subsubsection{Distribution of Contamination}

Observation wells at both the NHF and OHF were logged with a passive gamma ray tool prior to initiating batch waste injections at the new site (Weeren 1984f). The purpose of this logging event was to establish a baseline to aid in recognition of new grout sheets, to monitor the lateral extent of grout, and check on whether the new grout sheets merged with the OHF grout sheets. Well 1975 was found to be obstructed at approximately $700 \mathrm{ft}$ during this logging event. The gamma ray logging tool was not decontaminated between well logging runs (personal communication, Weeren 1995). Therefore, based on the known contamination within the standing water column in OHF wells, it can be assumed that cross-contamination through transferable radionuclides occurred during this and subsequent gamma ray logging runs while NHF was in operation. Use of the contaminated gamma ray logging tool, however, would not have impacted recognition of grout sheets at NHF; the strong gamma ray signatures of the sheet would be readily apparent.

The observation wells at both hydrofracture sites were again logged after the first injection (ILW-19). No new grout sheets related to initial batch injection operations at NHF were located at OHF. This is the last report of the observation wells at OHF having been logged during NHF operations. Results of the passive gamma ray logs are summarized in Table 4.8. The data indicate that the cured waste grout is confined to the injection horizon. The shallowest grout sheet located was in Well 1970 at a depth of $832 \mathrm{ft}(-44 \mathrm{ft} \mathrm{msl})$. These results, along with recent borehole geophysical logs run in 1995, were used to construct two generalized cross sections to present the spatial distribution of the NHF grout sheets and grout filtrate (Figs. 4.22 and 4.23). The A-A' cross section rums approximately east-west along geologic strike and the B-B' runs approximately northeast-southwest tying OHF to NHF.

The contaminated grout sheets injected at NHF do not extend in a simple radial pattern from the injection point (Well 1968). Spatially, the grout sheets appear to extend updip to the northwest and along geologic strike (northeast/southwest). The shape would be roughly elliptical with the long axis parallel to strike. The grout extends approximately $500 \mathrm{ft}$ to the north towards OHF and $>400$ $\mathrm{ft}$ to the south, northeast, and southwest. It appears that the grout followed a plane of weakness generally parallel to geologic strike. The actual extent of grout is unknown. Some interfingering of the grout sheets occurred to the north, towards OHF.

Prior to operations at NHF, six observation and eight rock cover wells were installed around the site. These wells were geophysically logged with conventional logging tools, and at least in one case (Well 1977), core was taken and described to establish formation contacts. There is no record, however, of baseline groundwater sampling and analysis for any of these wells. Therefore, it is only possible to discuss water chemistry based on historical and recent (1995) sampling after cessation of hydrofracture operations at NHF. The analytical results are summarized in Tables 4.1 through 4.3. The historic $\mathrm{pH}$ in Fig. 4.24 is presented with rock types. This presentation is not meant to imply "lateral" variation in $\mathrm{pH}$. 


\section{4-15}

Rock Cover Wells. The average TDS for all three recently collected samples from the rock cover wells is $161,768 \pm 49,949 \mathrm{mg} / \mathrm{L}$. TDS results for rock cover Wells 1974,1971 , and 1973 are displayed in Fig. 4.25. The water is a natural brine that has not been altered by influx of filtrate from the grout sheets.

The water in these wells does not appear to be stratified, which implies that the casing integrity is good and influx/mixing through casing to the wellbore has been minimal. The source of the briny water in the rock cover wells is from the Rogersville Shale/Rutledge Limestone section below approximately $500 \mathrm{ft}$.

Nitrate was not detected and radionuclides representative of the injected grout were detected in trace concentrations in the water sampled from the rock cover wells. Figures 4.26 and 4.27 show total gamma and beta activity for rock cover Wells 1974, 1971, and 1973. These results suggest that the injected grout wastes have had a minimal impact on the rock cover (Rogersville/Rutledge Limestone). The source of the radionuclides present could be from very minor upward migration from the grout sheets or lateral migration from the injection well (Switek 1987). Past crosscontamination may have contributed to the radiological contamination.

Observation Wells. The 1995 analytical results presented for the observation wells are the only known analytical data set. Water sampled is not representative of the natural geochemical system. The TDS concentrations are generally in the fresh to brackish range (100 to 2,000 mg/L). The TDS results for observation Wells 1972, 1975, 1978, and 1982 are spatially depicted in Fig. 4.25.

Observation wells (Wells 1972 and 1977) with low TDS and high $\mathrm{pH}$ values suggest that the well casing is in good condition and not open (breached) to allow influx of groundwater. The water present in the borehole is a remnant of well installation and grout injection monitoring activities. The observation wells $(1975,1978$, and 1982) with casing integrity compromised at depth, however, have received influx of contaminated grout filtrate. This effect would tend to slightly increase the TDS/conductivity and elevate the $\mathrm{pH}$ due to reaction with grout. The relatively higher TDS concentrations and very basic pHs measured in the bottom sample from Wells 1975, 1978, and 1982 would indicate influx of grout filtrate to the wellbore.

The bottom samples in observation Wells 1975,1978 , and 1982 are highly contaminated with significant concentrations of radionuclides (total gamma $14 \mu \mathrm{Ci} / \mathrm{L}$ [1975], gross beta $32 \mu \mathrm{Ci} / \mathrm{L}$ $[1978],{ }^{3} \mathrm{H}$ maximum $2 \mu \mathrm{Ci} / \mathrm{L}[1975],{ }^{60} \mathrm{Co}$ maximum $0.03 \mu \mathrm{Ci} / \mathrm{L}[1978],{ }^{137} \mathrm{Cs}$ maximum $2 \mu \mathrm{Ci} / \mathrm{L}$ [1975], and ${ }^{\text {D }} \mathrm{Sr}$ maximum $20 \mu \mathrm{Ci} / \mathrm{L}$ [1978], ) and nitrate (maximum $12600 \mathrm{mg} / \mathrm{L}$ [1975]) (Tables 4.2 and 4.3). The spatial distribution of total gamma and gross beta activity for these wells is included in Figs. 4.26 and 4.27. Note that the highest activity is confined to the grout sheets. These results support loss of casing integrity (probably caused by uplift due to grout injections) and influx of contaminated grout filtrate from NHF injections.

Deep Monitoring Wells. The deep monitoring wells were installed after cessation of NHF operations in January 1984 . Well 2375 has a TDS content of $35,422 \mathrm{mg} / \mathrm{L}$, similar to natural sea water, and is anomalous when compared to the other deep monitoring and rock cover wells in the NHF area. Well 2375 also has a high sulfate content (602 to $1070 \mathrm{mg} / \mathrm{L})$.

In general, TDS in the wells does not appear to be stratified (Fig. 4.25). Casing integrity based on chemistry appears to be moderately good (good isolation) and fresh water from the overlying strata (primarily Nolichucky Shale, Maryville Limestone, and Rogersville Shale) does not appear to have entered the wellbore and diluted the water. 
It was discovered by ORNL that groundwater in Wells 2373 and 2374 (openhole from the Rogersville Shale into the Rome Formation) was contaminated with significant concentrations of nitrate and the major radionuclides $\left({ }^{137} \mathrm{Cs},{ }^{60} \mathrm{Co},{ }^{90} \mathrm{Sr}\right.$, and ${ }^{3} \mathrm{H}$, and traces of short lived $\left.\mathrm{Ru}-106\right)$ that were included in the grout injections (Tables 4.4 through 4.6). After discovery of contamination, Wells 2373 and 2374 were recompleted as Rome Formation completions. Figures 4.28 and 4.29 show the radiological data collected from these two wells. Activity is plotted along the $x$-axis, and depths (bgs or msl) are plotted on the primary and secondary $y$-axis. The rock types are included for illustration and are not meant to imply horizontal extent. The results presented are from the groundwater samplings before and after well reconfiguration.

The results for gross beta ${ }^{60} \mathrm{Co},{ }^{90} \mathrm{Sr}$, and ${ }^{3} \mathrm{H}$ before the wells were reconfigured show an intense peak (highest activity) in the injection horizon. It was unknown, because at the time of sampling the wells had long openhole intervals, whether the contaminants were emanating from the Pumpkin Valley Shale or from other exposed units. The aqueous radionuclides that contaminate the groundwater are, however, sourced from the grout sheets. No radiological contamination was discovered in Well 2375, which is approximately $1,000 \mathrm{ft}$ northwest of NHF.

After recompletion as Rome Formation wells, groundwater sampling confirmed radiological contamination. This contamination in the Rome, however, is believed to be relic from mixing and allowing the wellbore to remain open to the Pumpkin Valley Shale (injection zone) for a period of time.

A full suite of openhole borehole geophysical logs for the original deep monitoring wells were collected and interpreted prior to the initial groundwater sampling (Haase 1987). Haase concludes based on interpretation of borehole televiewer and other logs that an active, open fracture system is present within the Pumpkin Valley Shale (injection horizon). It was also suggested that the fractures were induced by hydrofracture and extend for a distance from the setup grout.

After discovery of contamination, the three original wells were recompleted by shortening the openhole interval to monitor specific formations [Rome Formation (2373 and 2374) and Pumpkin Valley Shale (2375)]. Four additional wells were also installed: 2952, 2953, 2954, and 2955. Results indicate very high radiological contamination in the two "new" Pumpkin Valley (injection horizon) wells (2954 and 2955) (Tables 4.4 and 4.5). Recent radiological results indicate the following maximum concentrations in the Pumpkin Valley Shale wells: total gamma $0.05 \mu \mathrm{Ci} / \mathrm{L}$ (2955), gross beta $98 \mu \mathrm{Ci} / \mathrm{L}(2954)$, gross alpha $0.005 \mu \mathrm{Ci} / \mathrm{L}(2955),{ }^{90} \mathrm{Sr} 4.5 \mu \mathrm{Ci} / \mathrm{L}(2955)$, and ${ }^{3} \mathrm{H} 0.3 \mu \mathrm{Ci} / \mathrm{L}$ (2954). Contamination in the Rutledge Limestone wells (2952 and 2953) is at low levels.

The spatial distribution of total gamma and gross beta activity is shown in Figs. 4.26 and 4.27. Note that the gross beta activity is higher in the east deep monitoring well cluster than in the west cluster. Total gamma activity is just the opposite, with higher activity in the west cluster.

The natural passive gamma log acquired through casing from Well 2373 as part of the full suite of logs collected in 1995, detected the presence of grout filtrate in the upper Pumpkin Valley Shale. Gamma anomalies, or spikes, appear at $930 \mathrm{ft}$ and $944 \mathrm{ft}$. The magnitude of the gamma spike at $944 \mathrm{ft}$ (183 cps) is significant for two reasons: it is higher than expected for the upper Pumpkin Valley Shale, and the gamma log was recorded through steel casing, which greatly attenuates the gamma signal. Additionally, a comparison of the recent gamma log with historical openhole gamma log data run in 1985 (Law Engineering) (Fig. 4.30) illustrates the time-dependent nature of the development of the gamma spike at $944 \mathrm{ft}$; the spike was not present on the historical gamma log. It should be noted that the historical gamma log is measured in American Petroleum Institute (API) units and the recent gamma log is in cps (counts per second). The historical gamma data was recorded in an open 
borehole, not through steel casing. Thus, if the source of the gamma spike had been present at the time the historical gamma log was run, the magnitude would be higher than the gamma anomaly on the recent log.

Grout filtrate was detected in a second well of the 2373 (east) deep monitoring well cluster, Well 2954. Well 2954 is uncased from $747 \mathrm{ft}$ (the Rutledge Limestone/upper Pumpkin Valley Shale contact). The recent natural gamma log from Well 2954 (Fig. 4.31) in the openhole shows the extent of the grout filtrate plume (increased gamma counts) in the upper Pumpkin Valley Shale. The plume terminates at the contact of the upper and lower Pumpkin Valley Shale. There appears to be a strong correlation between this plume and the gamma anomaly at $944 \mathrm{ft}$ in Well 2373.

Grout filtrate was also detected in the upper Pumpkin Valley Shale in recent natural gamma log data from Well 2374. The gamma log indicates spikes over the cased interval at $894 \mathrm{ft}, 908 \mathrm{ft}, 910 \mathrm{ft}$, and $912 \mathrm{ft}$. The magnitude of the gamma spikes at $908 \mathrm{ft}(185 \mathrm{cps}), 910 \mathrm{ft}(170 \mathrm{cps})$, and $912 \mathrm{ft}$ (143 cps) is higher than would be expected for the upper Pumpkin Valley Shale. Once again the log was acquired through steel casing. A comparison of the recent and historical openhole gamma logs (Fig. 4.32) illustrates the time-dependent nature of the gamma spikes; the spikes are not present on the historical gamma log.

Aqueous radiological contamination in the Pumpkin Valley Shale is sourced from the grout sheets. The contamination in the Rome Formation is not believed to be representative of contaminated "Rome" formation water, but a "remnant" from when the well had a long openhole interval through the injection horizon (Pumpkin Valley Shale) into the Rome Formation.

The east deep monitoring well cluster, which is located approximately $1,000 \mathrm{ft}$ east of NHF, contains three wells $(2373,2952$, and 2954), open to three different formations (Rome Formation, Rutledge Limestone, and Pumpkin Valley Shale, respectively) (Fig. 4.6). Head measurements made in the three wells indicate an upward gradient from the Pumpkin Valley Shale to the Rutledge Limestone. These measurements would support the conclusion that contamination in the Rome Formation is not representative but relic.

\subsubsection{Summary}

Spatially, the grout sheets injected at NHF form an elliptical body that extends updip approximately $500 \mathrm{ft}$ from the injection well (north). The long axis of the ellipse is parallel to strike and extends $>400 \mathrm{ft}$ to the east and west of the injection well. A grout filtrate plume is also present as a "halo" surrounding the grout sheets. The plume extends $<1,000 \mathrm{ft}$ to the north (updip) and $>1,000 \mathrm{ft}$ to the east and west. The eastern limit of the plume is unknown, but is expected to be less than the western extent. The grout sheets and plume appear to be confined to the injection horizon (upper Pumpkin Valley Shale).

The filtrate was sourced from low solids grout injections that allowed input of aqueous radiological contaminants into the Pumpkin Valley groundwater (native brine). The primary radiological contaminants are ${ }^{90} \mathrm{Sr},{ }^{60} \mathrm{Co}$, and ${ }^{137} \mathrm{Cs}$. The aqueous ${ }^{137} \mathrm{Cs}$ can be expected to be retarded in the induced or natural fracture network by adsorption/absorption. The ${ }^{90} \mathrm{Sr}$ and ${ }^{60} \mathrm{Co}$, however, would primarily remain in solution under present geochemical conditions but could possibly be retarded by matrix diffusion.

The contaminated grout filtrate preferentially flowed along a zone of weakness (microfracture/fracture system) to the east and west away from NHF injection point. The driving mechanism for migration of aqueous radiological contaminants during and shortly after hydrofracture 
injections was artificially induced pressure. The ambient head distribution regained control of the natural flow system as the induced pressure regime relaxed. Evidence from borehole geophysical logs strongly suggests hydraulically active fractures in the injection horizon. There is presently no evidence of a natural surface expression of radiological contaminants sourced from the grout sheets. 


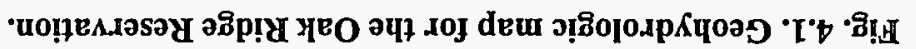

2.SD26 552

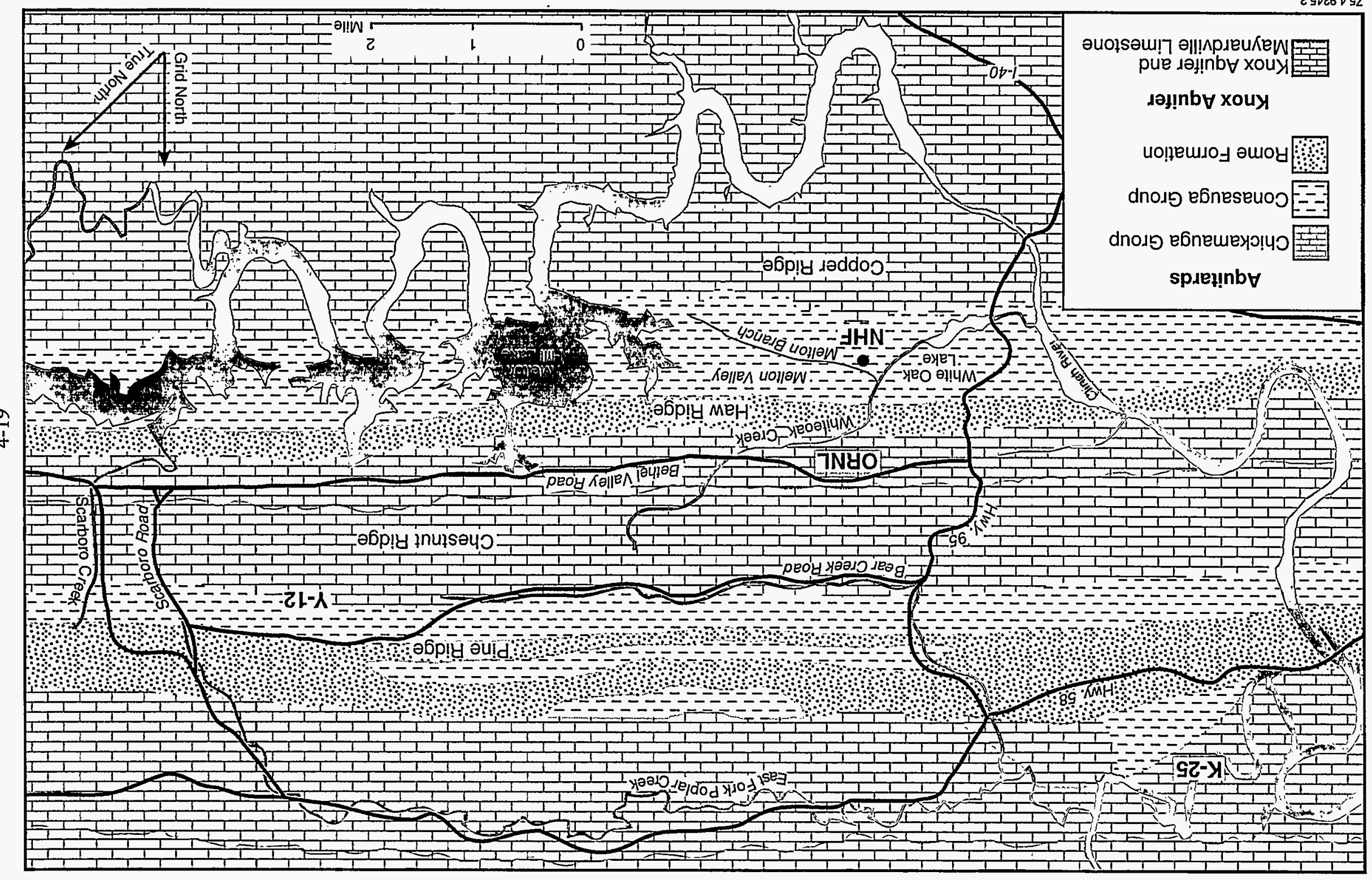


. - 


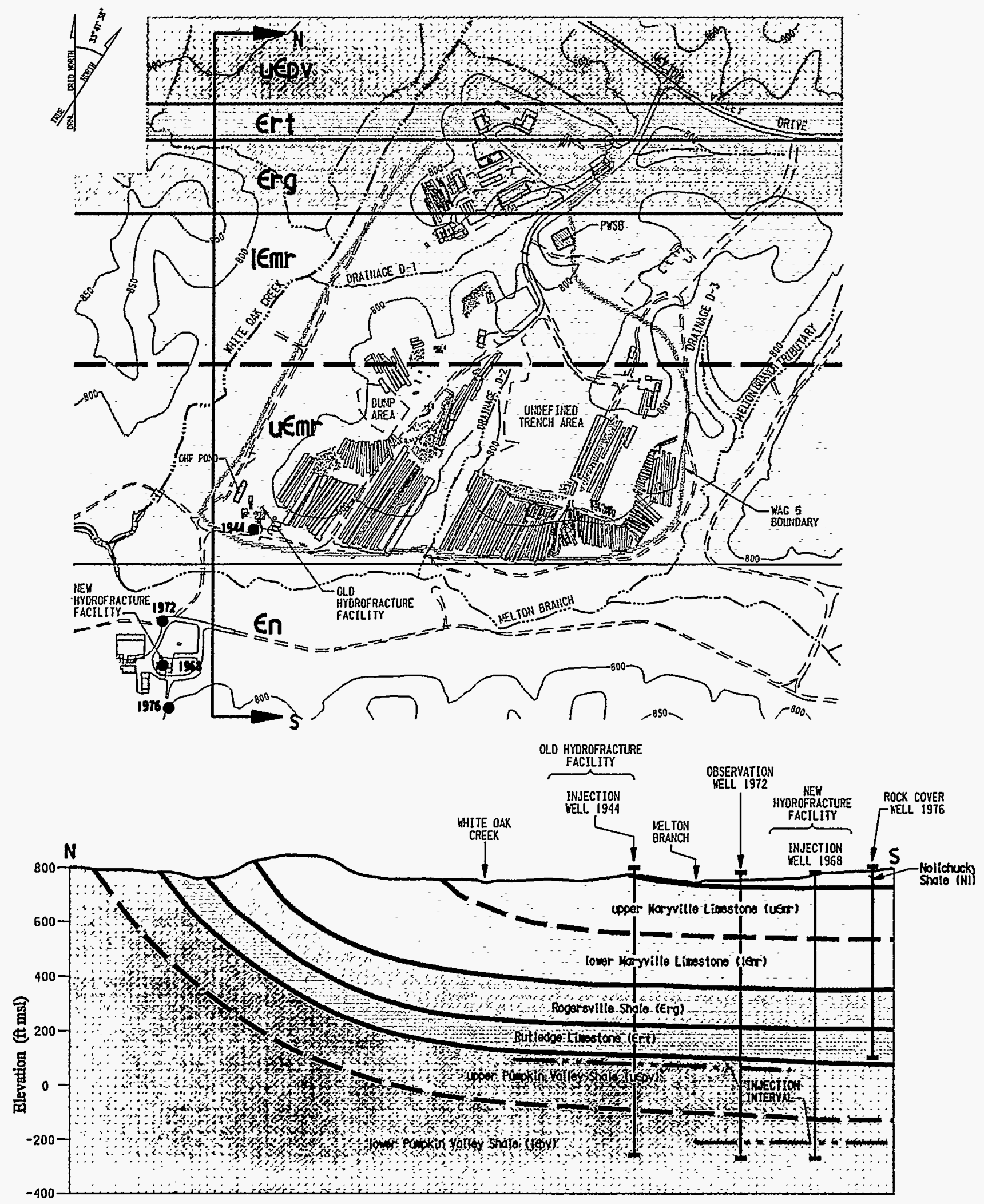

Fig. 4.2. WAG 10 generalized geologic map.

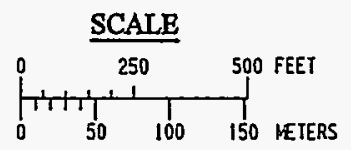





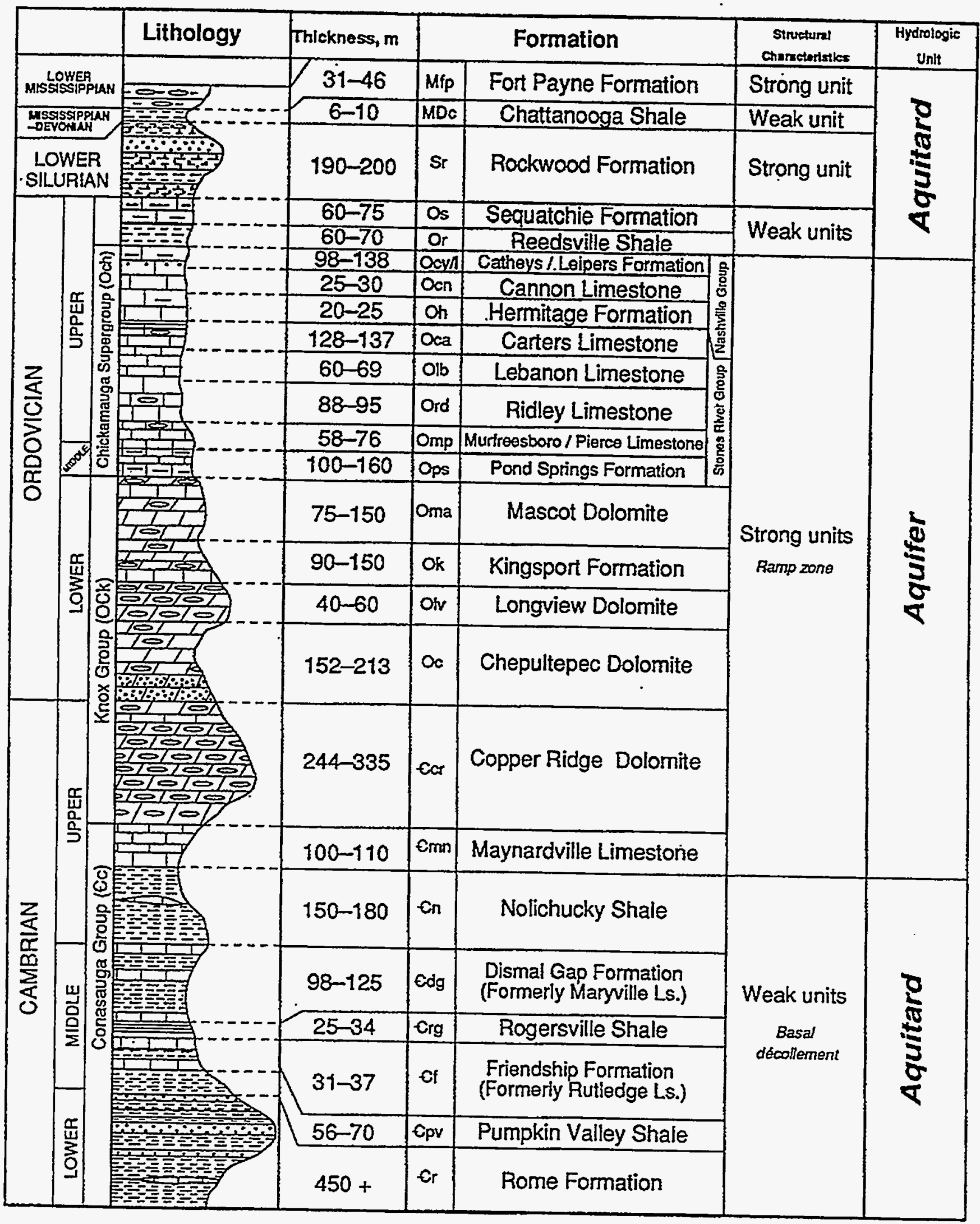

Fig. 4.3. Stratigraphic section in East Fork Valley, East Fork Ridge and Pilot Knob, Pine Ridge, Bear Creek Valley, and Chestnut Ridge. 


$$
\mathbf{N}
$$

Haw

Ridge

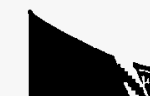

Och

(Ordovician Chickamauga Group)

Note: Not drawn to scale

Fig. 4.4. Structural and topographic controls for artesian flow at WAG 10.

IARIFS 7097.1 


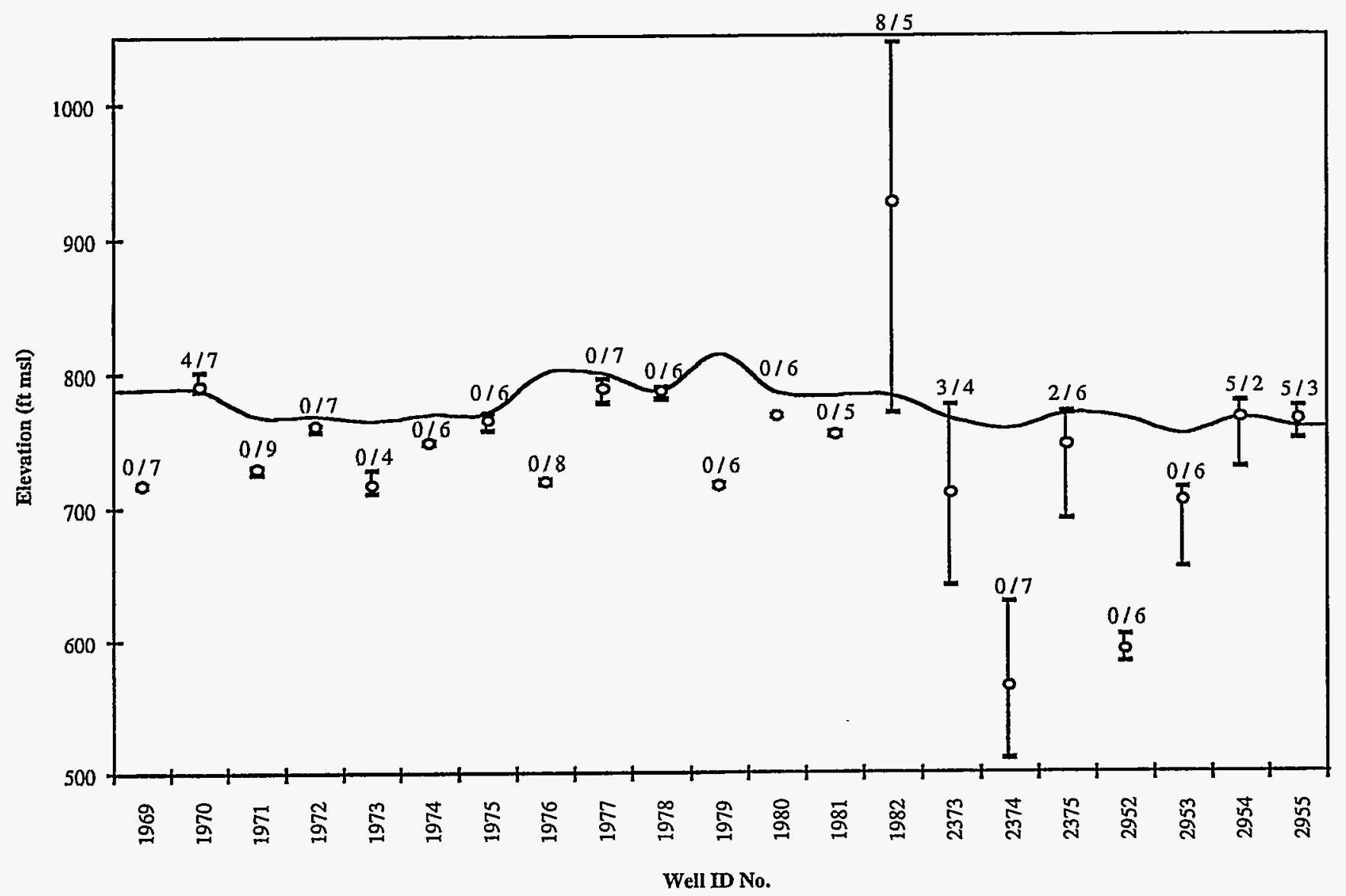

No. of pressure measurements

$$
\begin{aligned}
& \text { N/3 }- \text { of water level measurcments } \\
& \text { Maximum head, } \mathrm{ft} \text { msl } \\
& \text { Average head, } \mathrm{ft} \mathrm{msl} \\
& \text { Minimum head, } \mathrm{ft} \mathrm{msl}
\end{aligned}
$$

Notes:

- The minimum water level measurements for wells $2373,2374,2375,2952$, and 2953 were recorded after the tubing was pulled from the wells.

- Well 1982 was not under pressure in July 1995 after tapping; however, in September 1995, the well was observed to be artesian. After shutting-in the well, the pressure increased to 113 psi in December 1995.

Fig. 4.5. Total head measurements in WAG 10 New Hydrofracture Facility wells in Fall 1995. 
, 


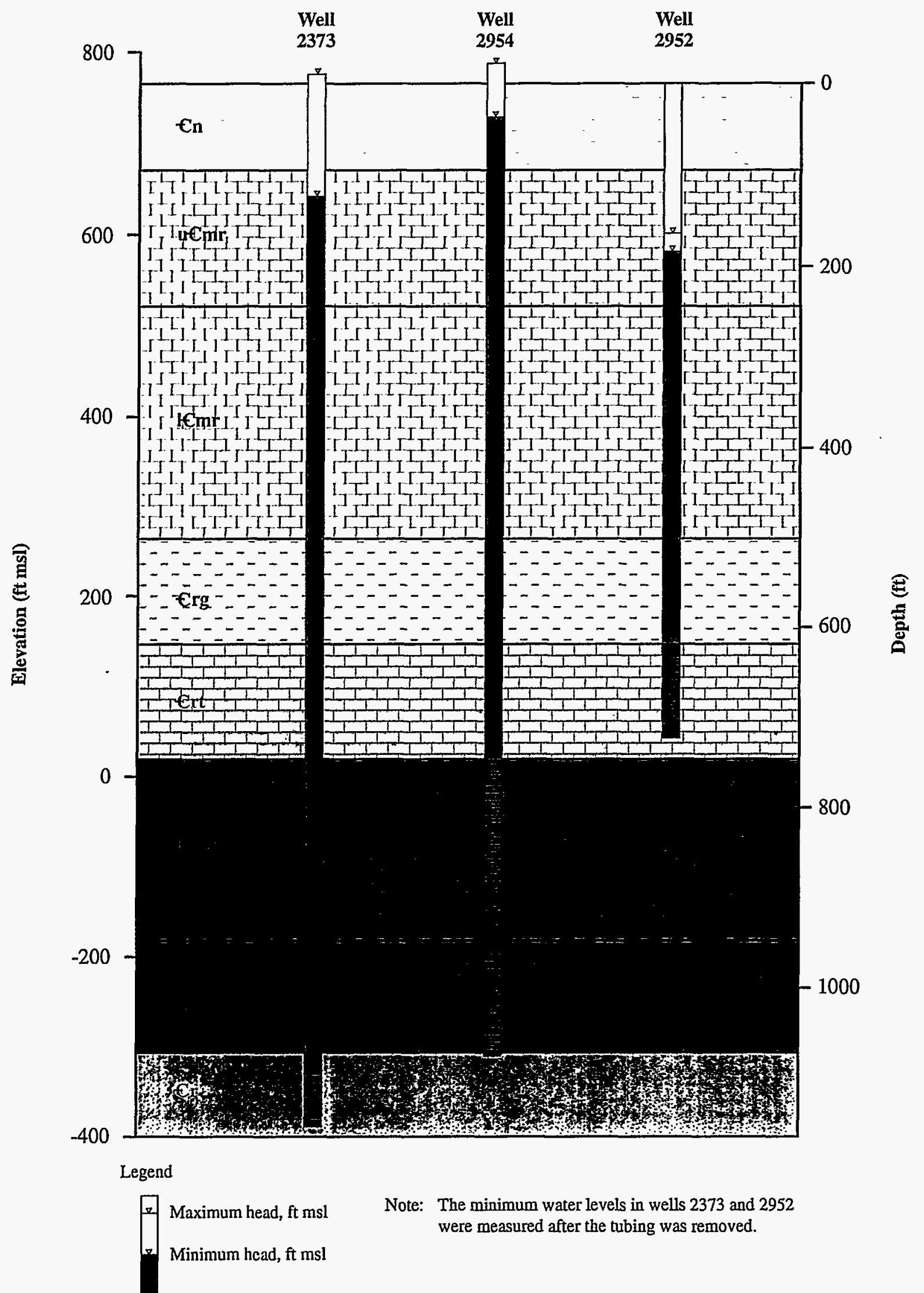

Fig. 4.6. Head measurements in DM1 wells cluster. 



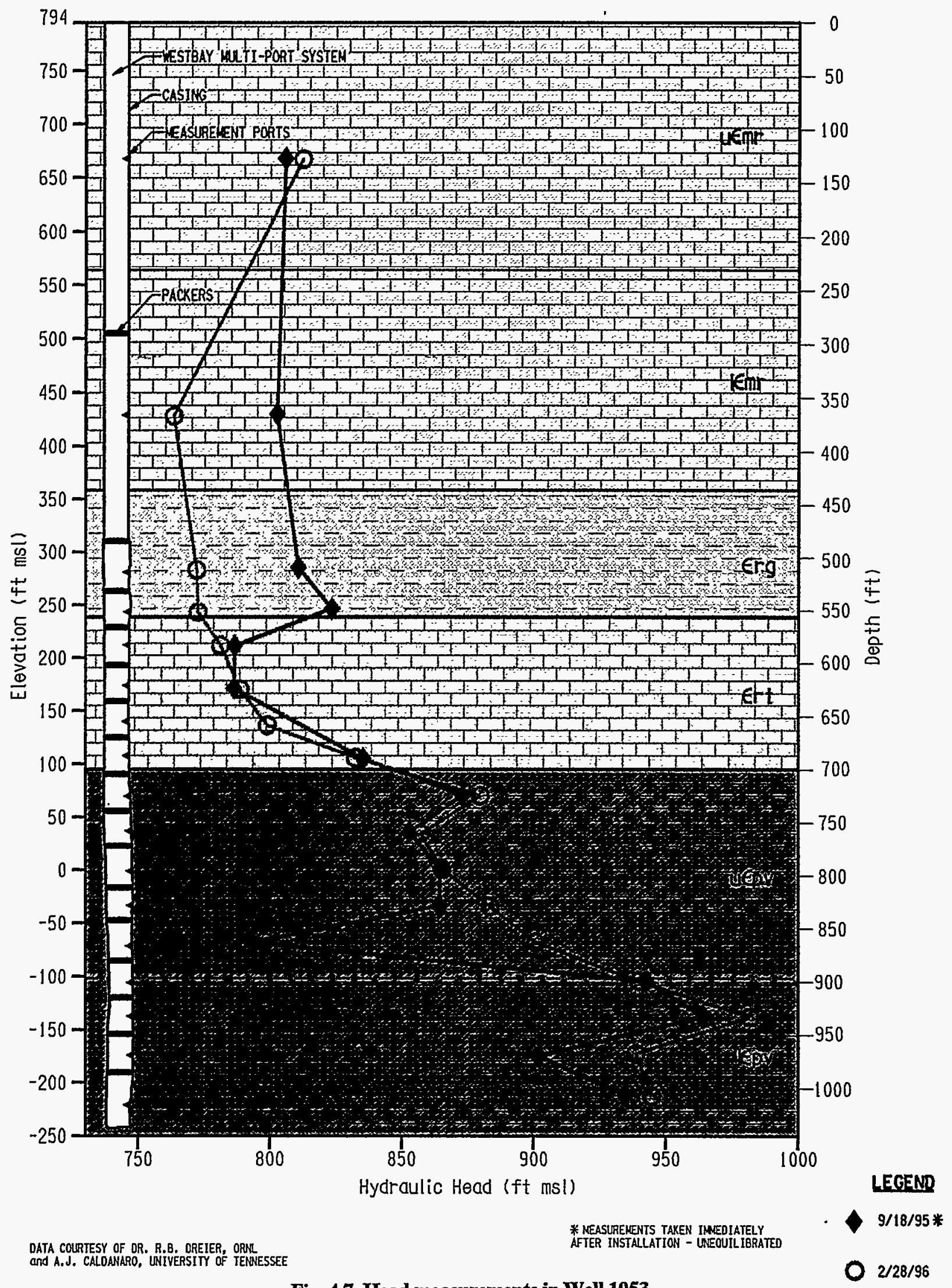

Fig. 4.7. Head measurements in Well 1953. 


\begin{tabular}{|c|c|c|c|c|c|c|c|}
\hline \multirow{2}{*}{$\begin{array}{l}\text { NHF } \\
\text { Ion Statistics }\end{array}$} & \multirow{2}{*}{$\begin{array}{c}\text { No. of } \\
\text { Samples }\end{array}$} & \multicolumn{6}{|c|}{ Ions, $\mathrm{mg} / \mathrm{L}$} \\
\hline & & Sodium & Potassium & Calcium & Magnesium & Chloride & Sulfate \\
\hline Maximuning ts & ond & and & 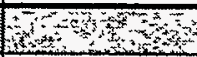 & 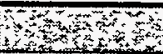 & now & 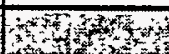 & $y+2 x+2 x$ \\
\hline Cased Wells & 14 & 37,000 & 854 & 2,080 & 20 & 35,100 & 811 \\
\hline Open Interval (0- & 37 & 68,200 & 316 & 33,400 & 5870 & 162,000 & 1,070 \\
\hline Open Interval $(700+\mathrm{ft})$ & 6 & 71,300 & 360 & 34,000 & 5440 & 163,000 & 602 \\
\hline 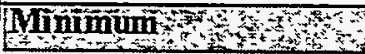 & 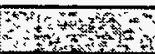 & 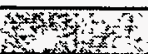 & wistos? & When & 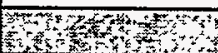 & 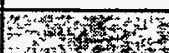 & sis \\
\hline Cased Wells & 14 & 5.9 & 2.68 & 2.4 & 0.2 & 5.95 & 0.4 \\
\hline Open Interval $(0-700 \mathrm{ft})$ & 37 & 6,220 & 17.7 & 676 & 78 & 10,100 & 20 \\
\hline Open Interval $(700+f t)$ & 6 & 18,000 & 49 & 3,930 & 822 & 33,700 & 20 \\
\hline Mean $3,3,1$ & $\sqrt{2}+\sqrt{2}$ & 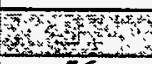 & Gens & 0 & 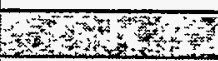 & thes & nats \\
\hline Cased Wells & 14 & 56 & 11 & 49 & 0.6 & 40 & 31 \\
\hline Open Interval $(0-700 \mathrm{ft})$ & 37 & 38,762 & 111 & 13,921 & 2,324 & 88,218 & 29 \\
\hline Open Interval $(700+f t)$ & 6 & 52,601 & 178 & 20,457 & 3,245 & 117,813 & 35 \\
\hline
\end{tabular}

Legend:

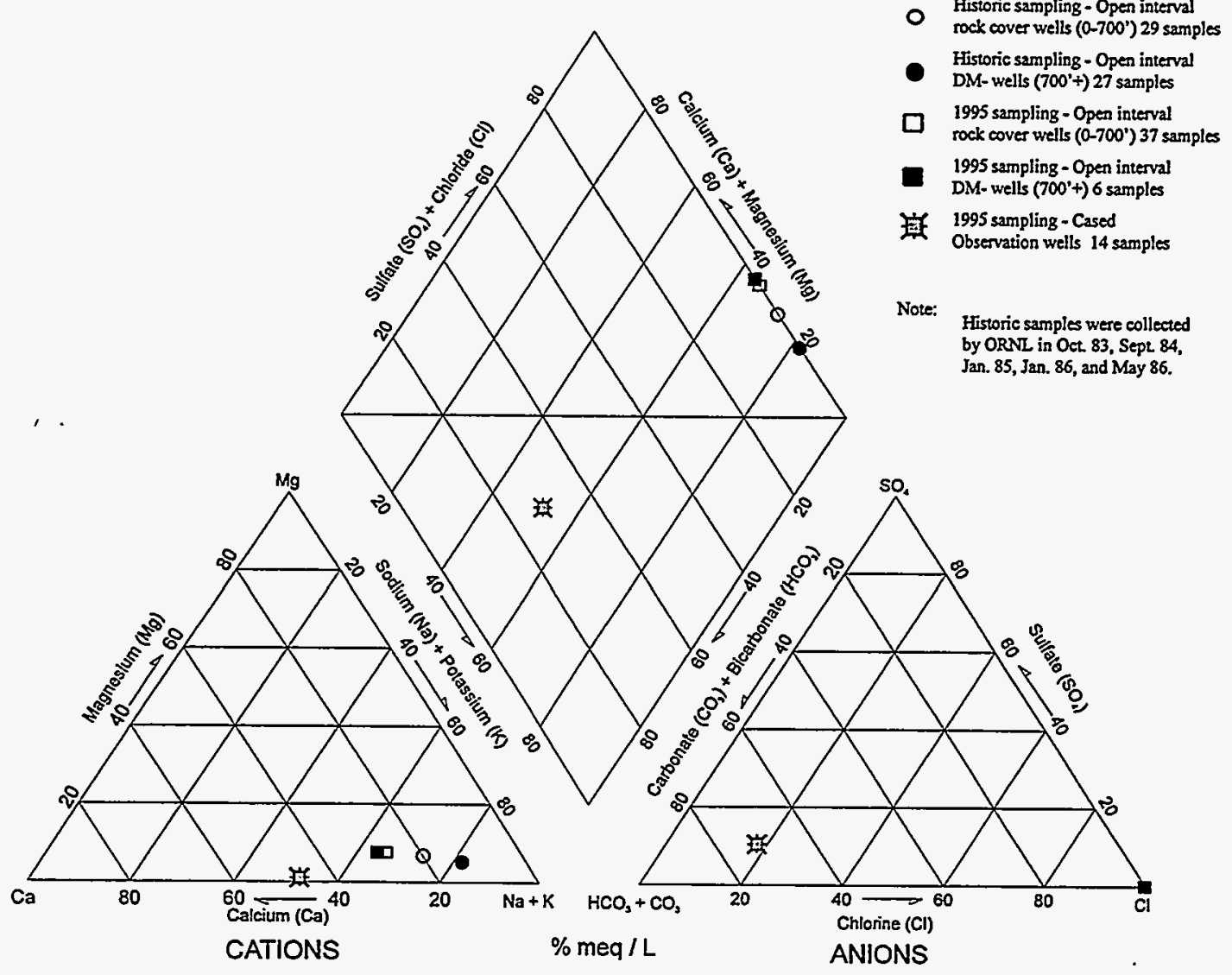

Fig. 4.8. Piper diagram using geometric mean values of selected ions from historic and 1995 sampling event. 


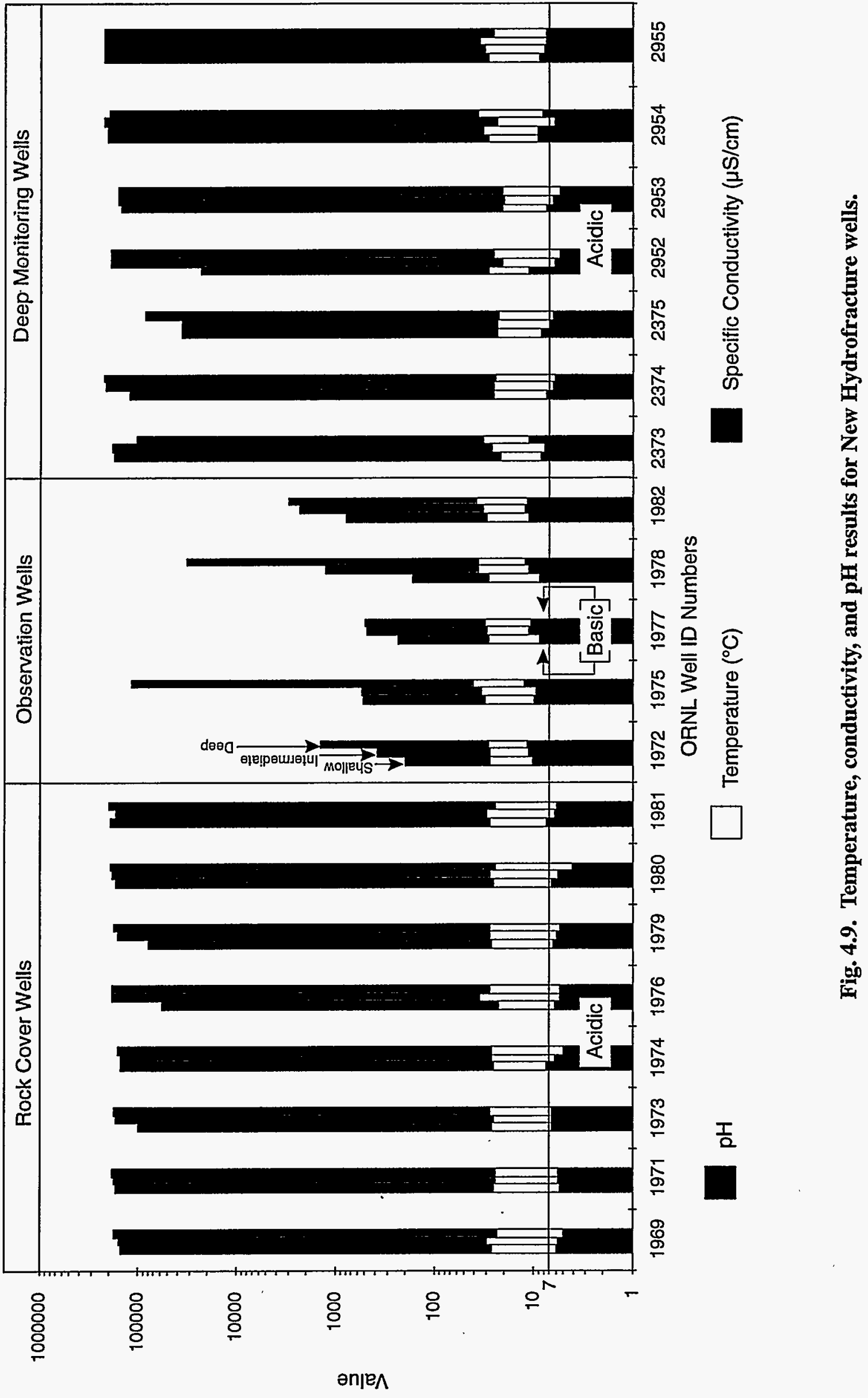


A.

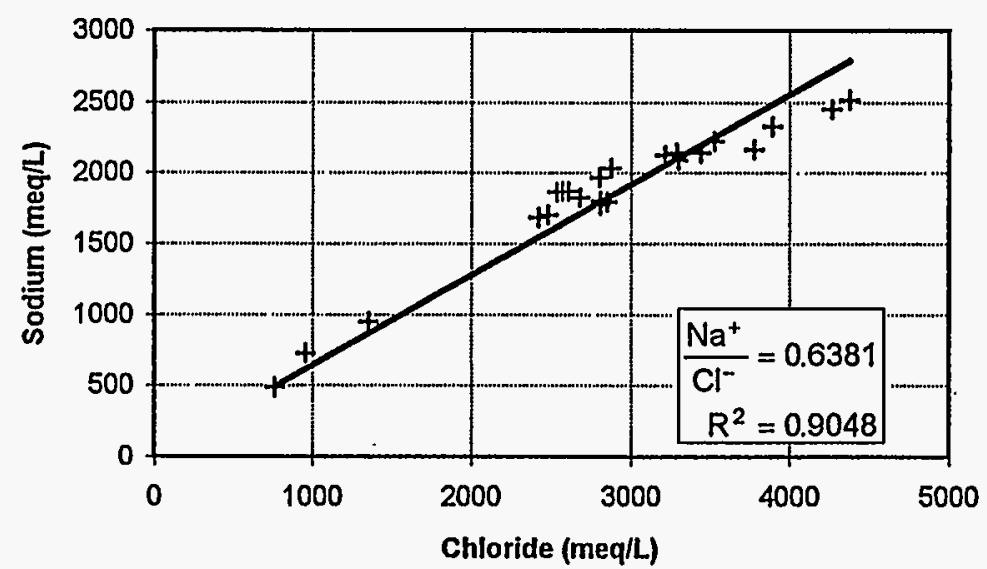

C.

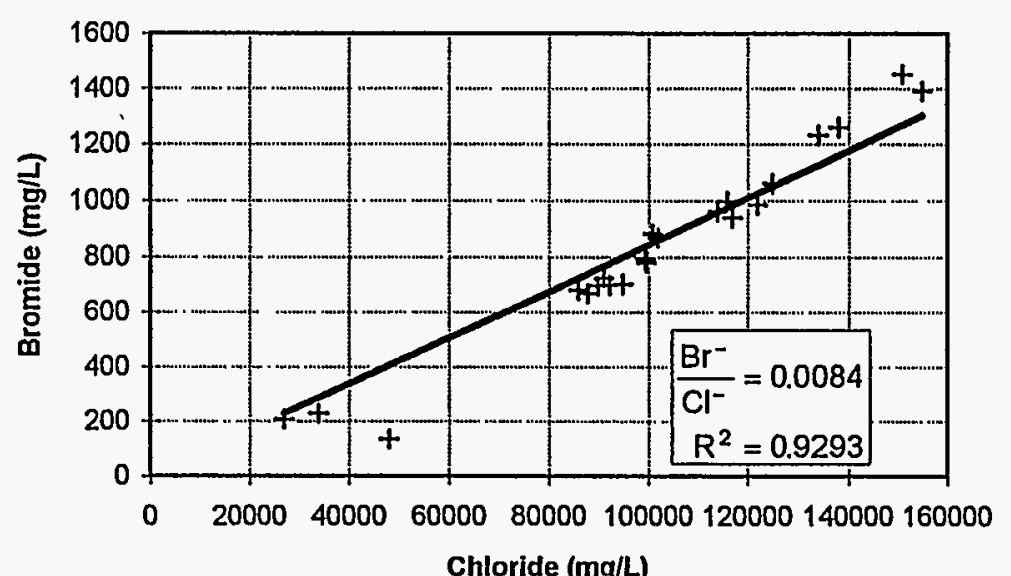

B.

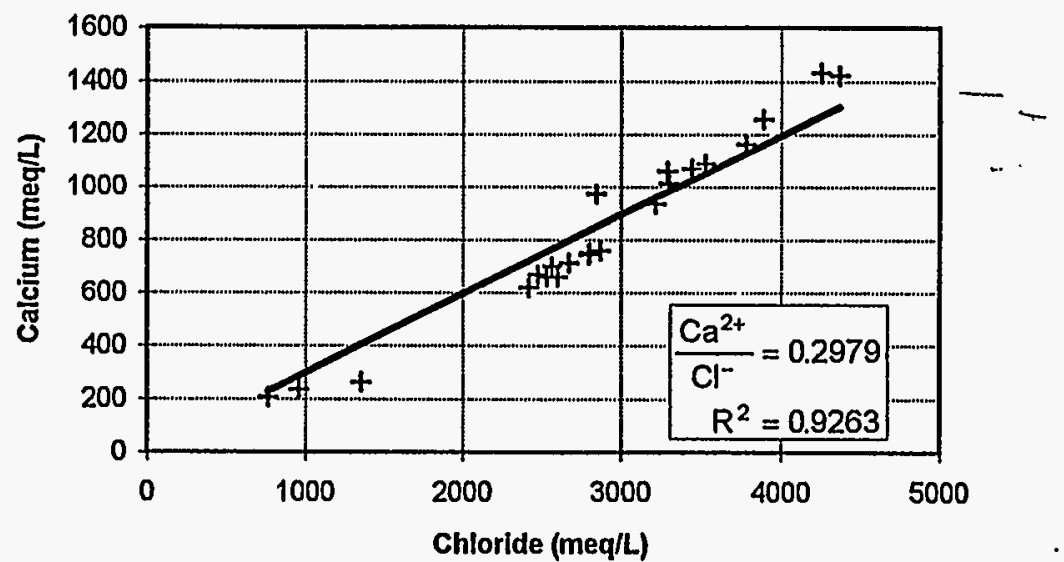

D.

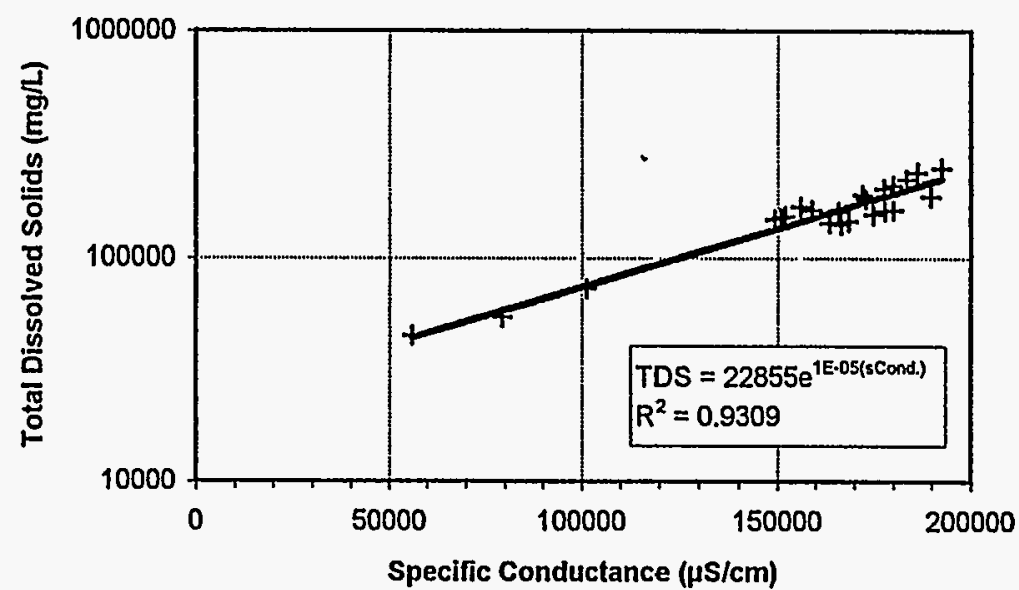

+ Samples from rock cover wells (1995 sample event)

Fig. 4.10. Chemistry of standing water column in New Hydrofracture Facility rock cover wells. 

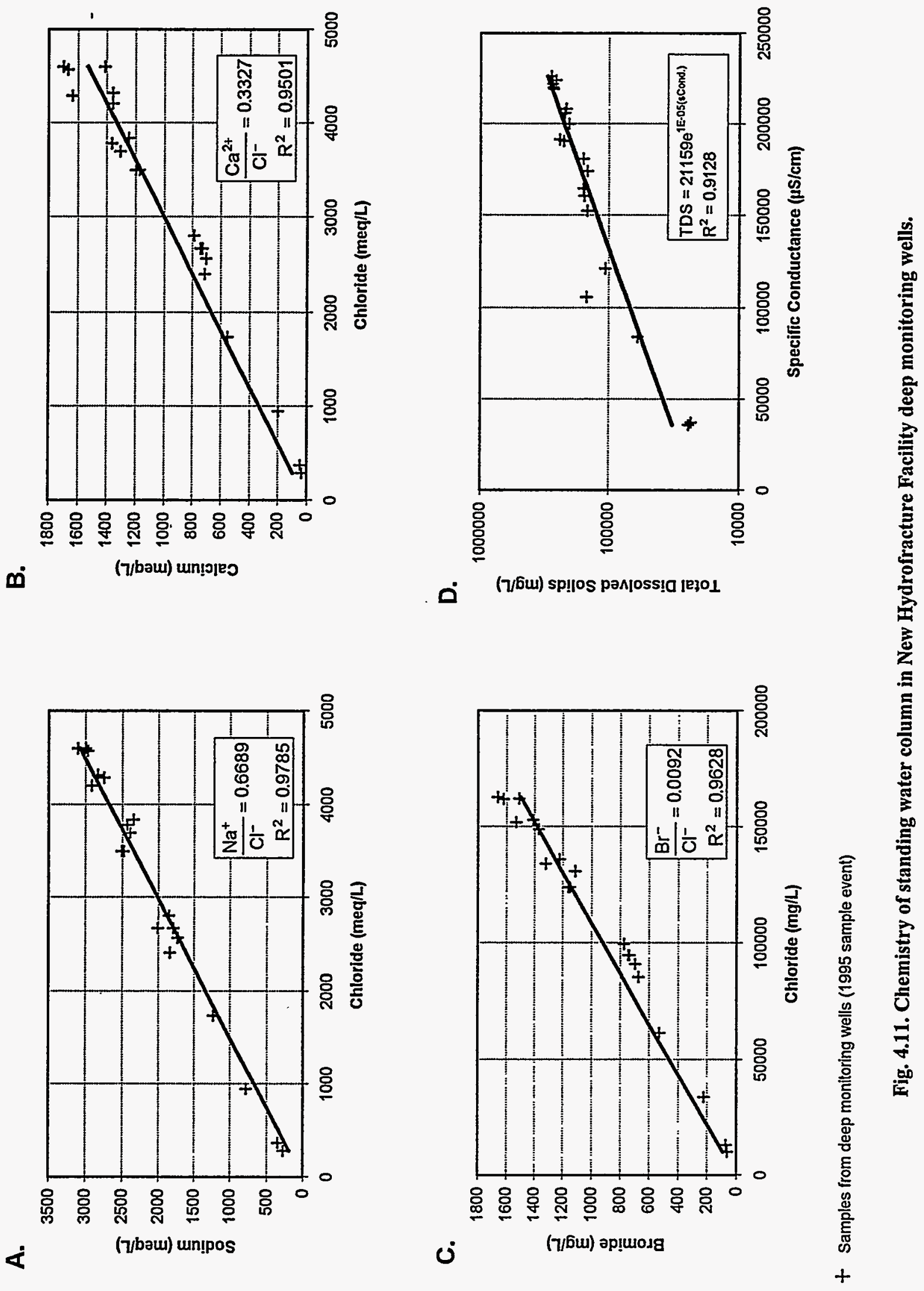


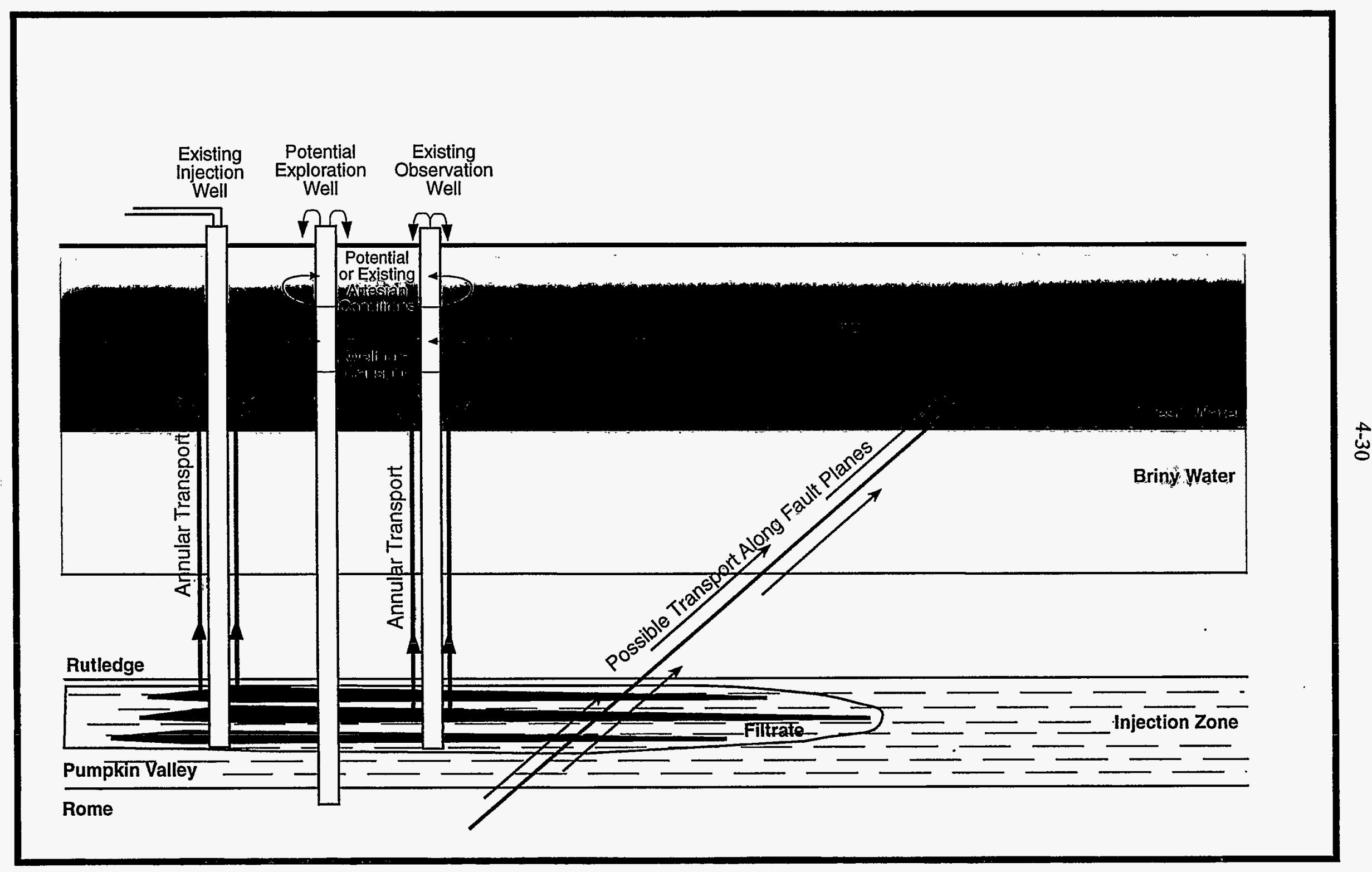

Fig. 4.12. Schematic representation of possible migration pathways for hydrofracture contaminants. 


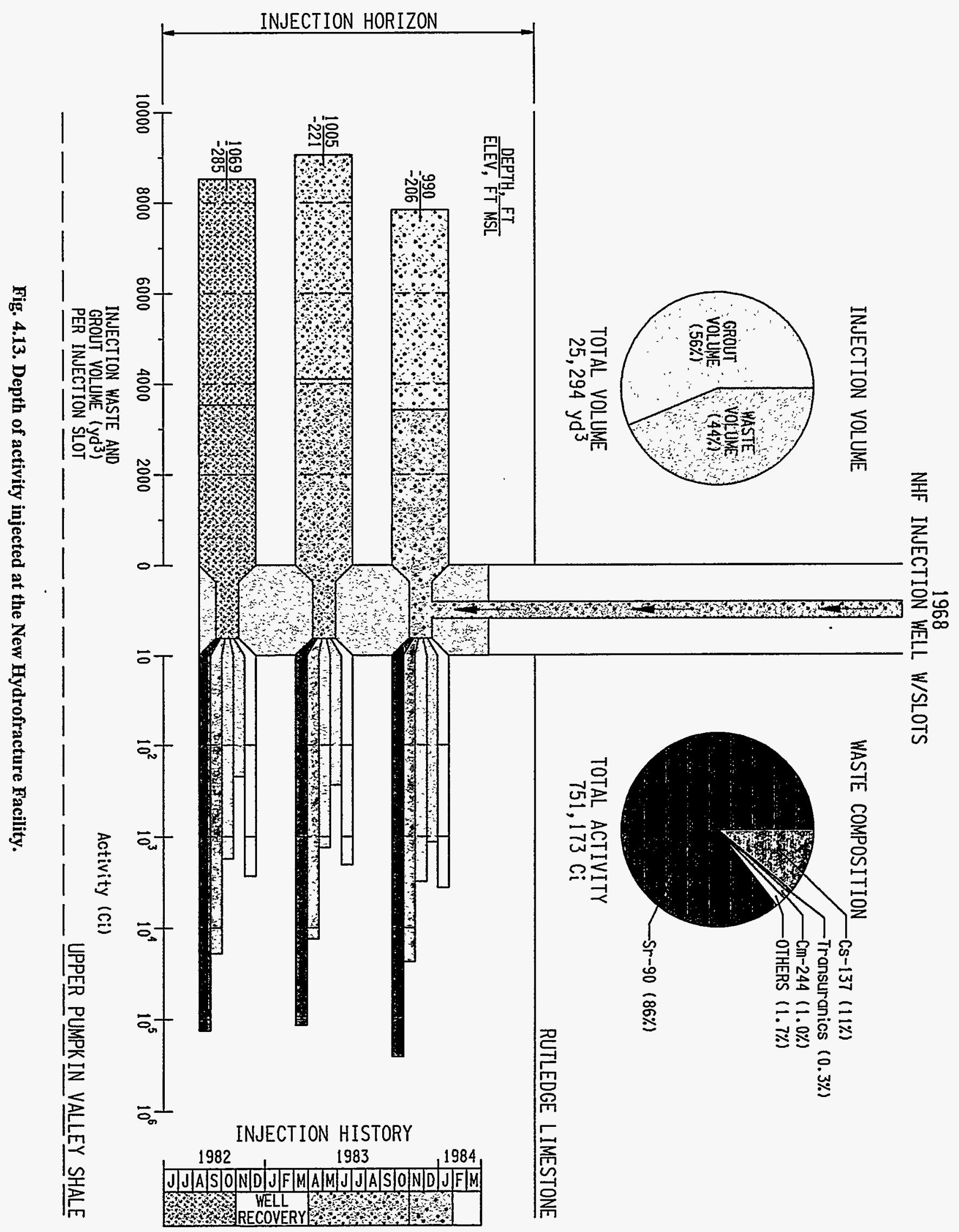




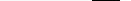




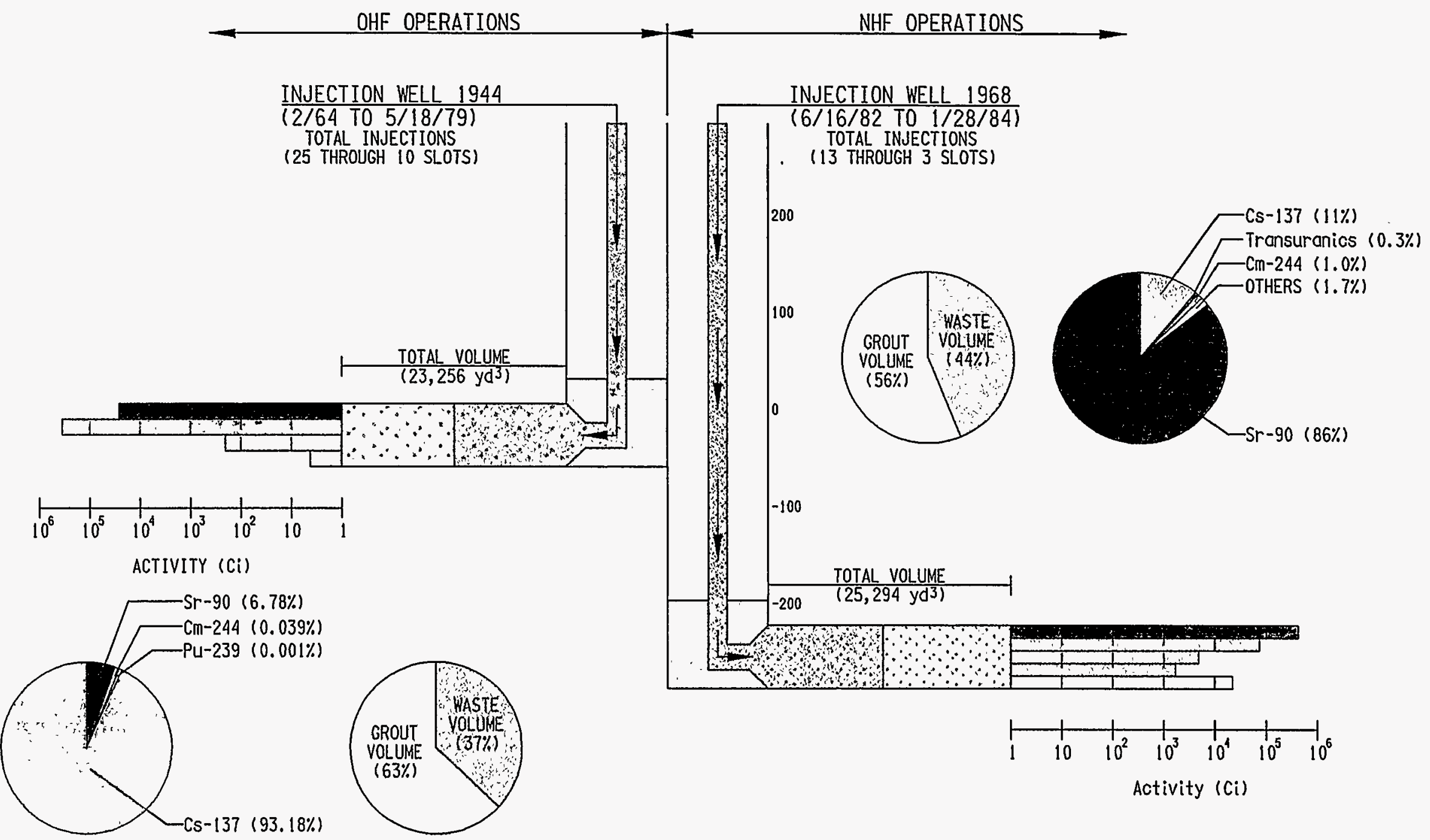

Fig. 4.14. Comparison of waste injected at the Old Hydrofracture Facility and New Hydrofracture Facility. 

A.

Waste Injection ILW-19 Slot No. 1 (1069 ft, -285 ft)

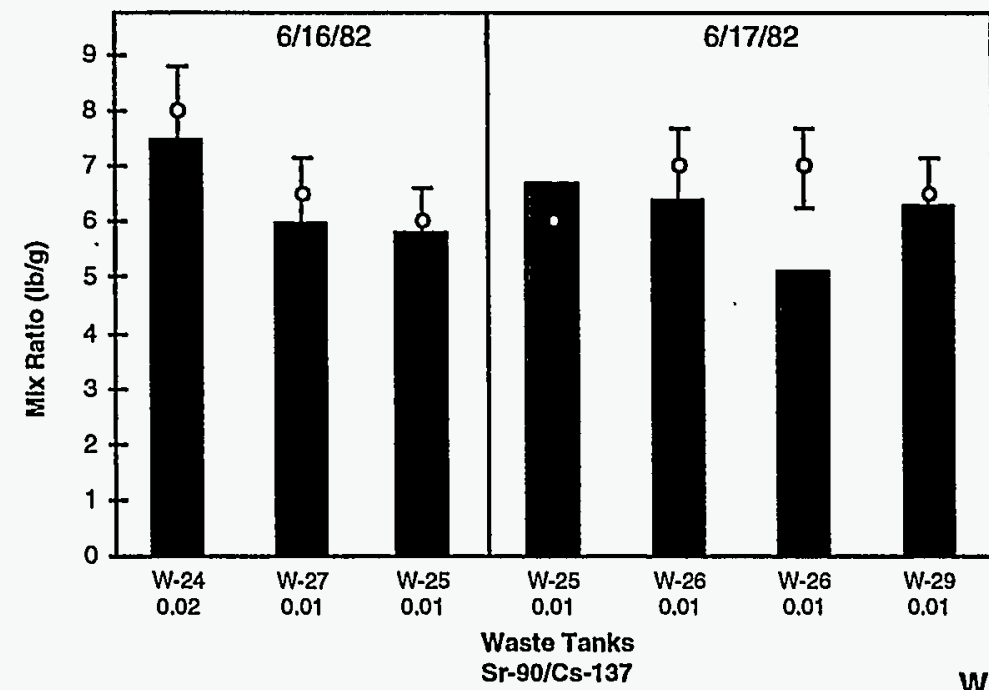

Waste Injection Sl-1

Slot No. 1 (1060 ft, $-285 \mathrm{ft})$

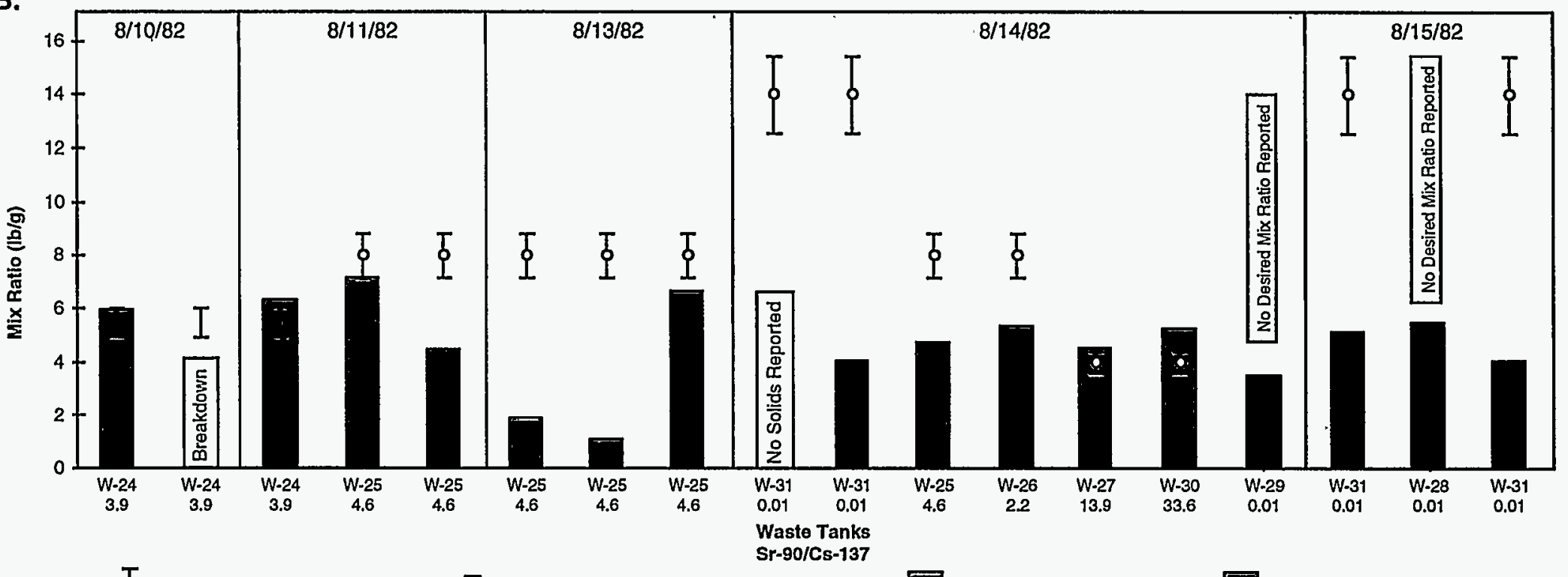

Legend: I Desired Mix Ratlo Range
C.

Waste Injection SI-2

Slot No. 1 (1069 ft, -285 ft)

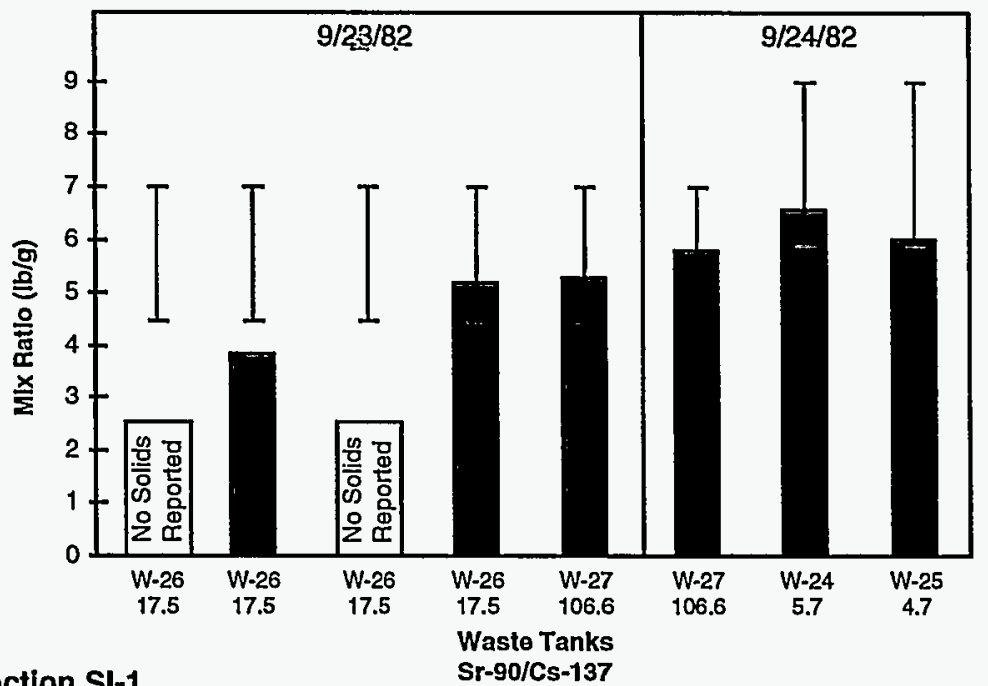

Fig. 4.15. Summary of desired and actual waste mix ratios used for injections ILW-19, SI-1, and SI-2. 


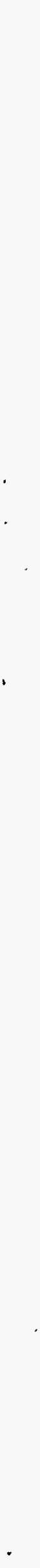


A.

Waste Injection SI-3

Slot No. 1 ( $1060 \mathrm{ft},-285 \mathrm{ft})$

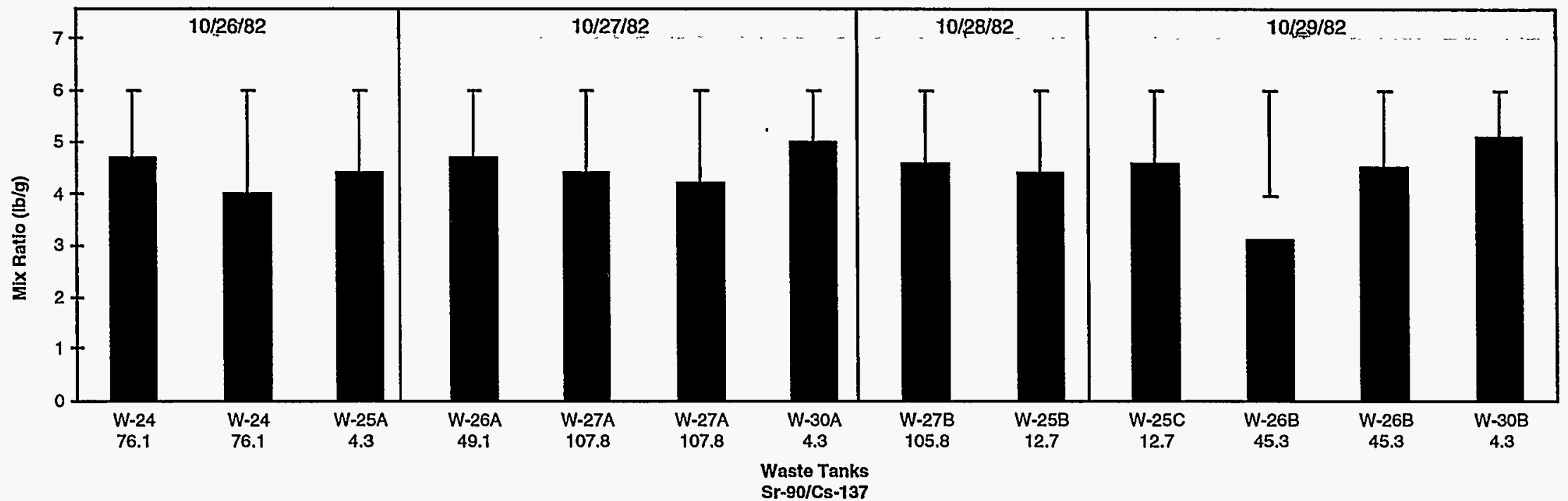

B.

Waste Injection SI-4 Slot No. 2 (1005 ft, -221 ft)

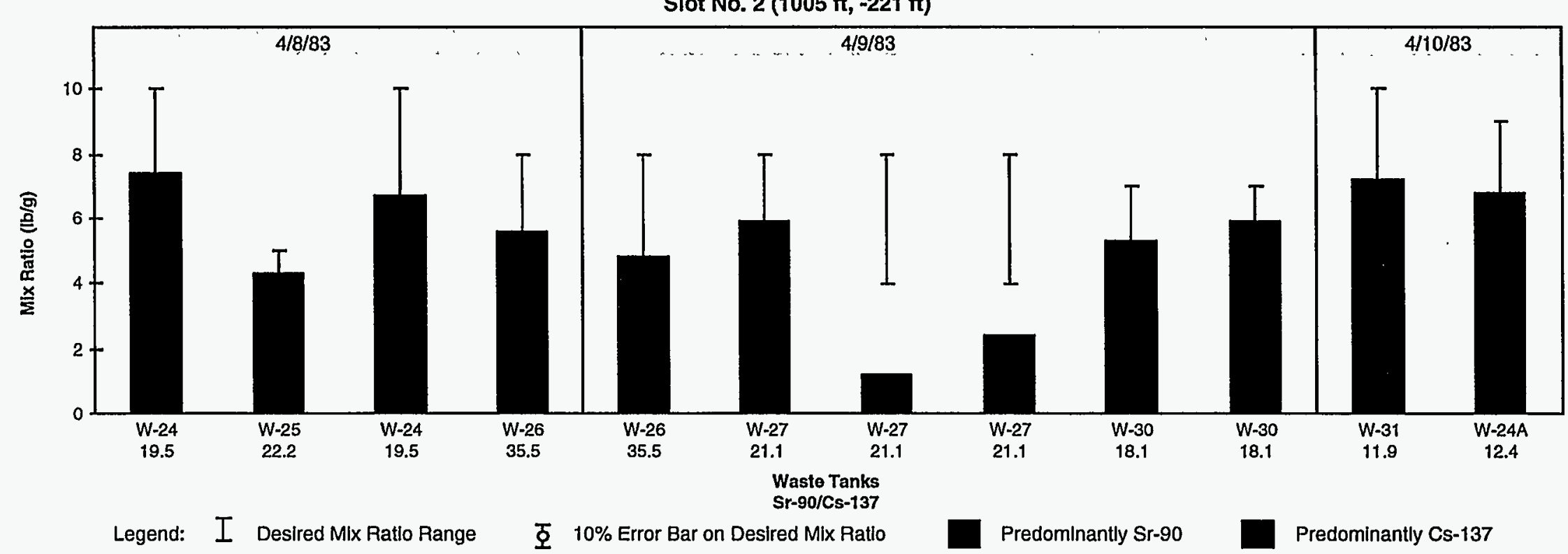

Fig. 4.16. Summary of desired and actual waste mix ratios used for injections SI-3 and SI-4. 


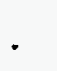


Waste Injection S1-5

Slot No. 2 (1005 ft, -221 ft)

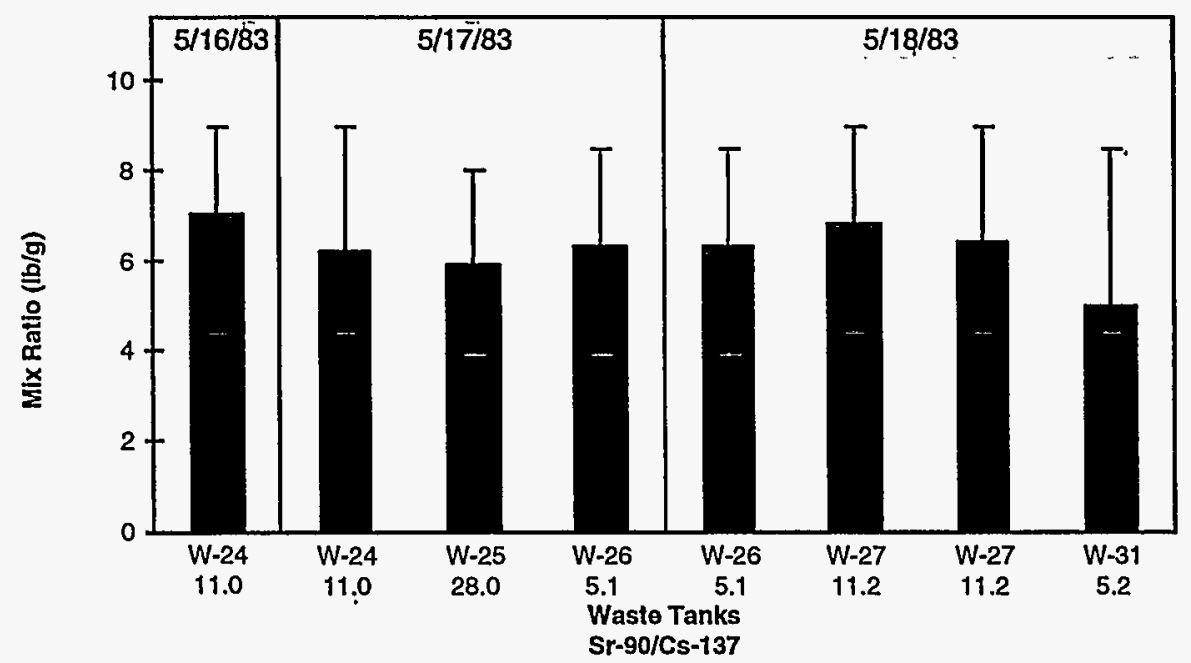

C.

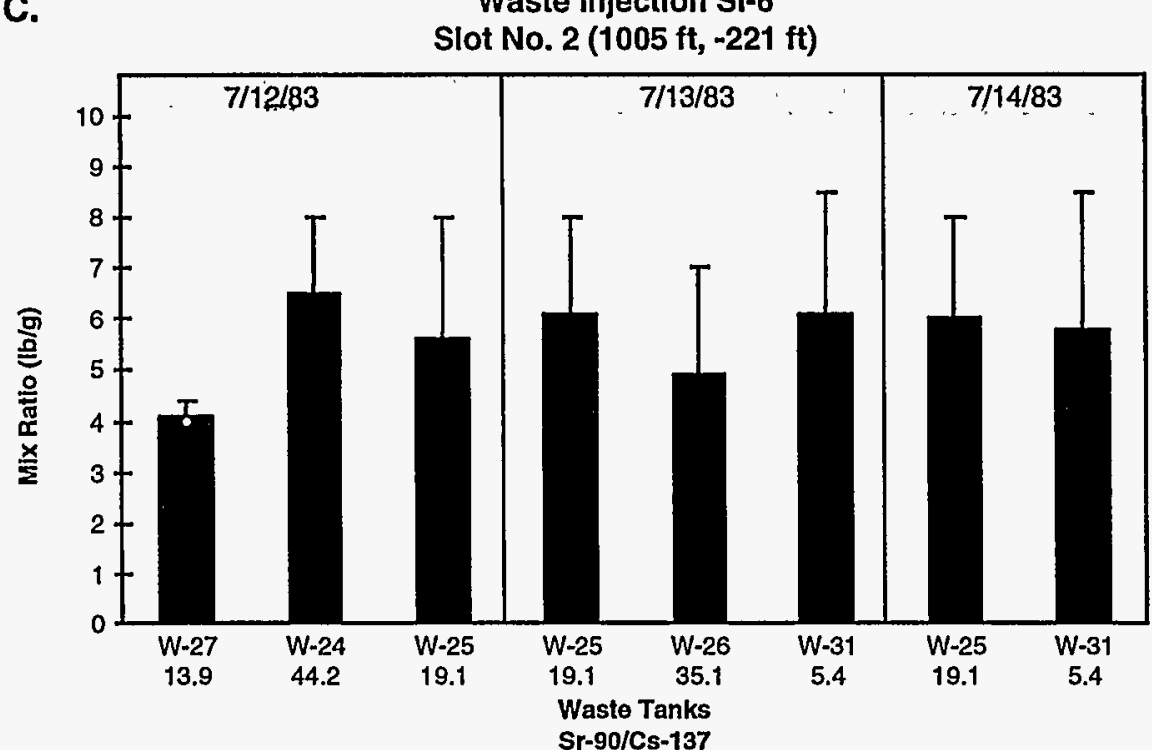

Legend: I Desired Mix Ratio Range
B.

Waste Injection ILW-20

Slot No. $2(1005 \mathrm{ft},-221 \mathrm{ft})$

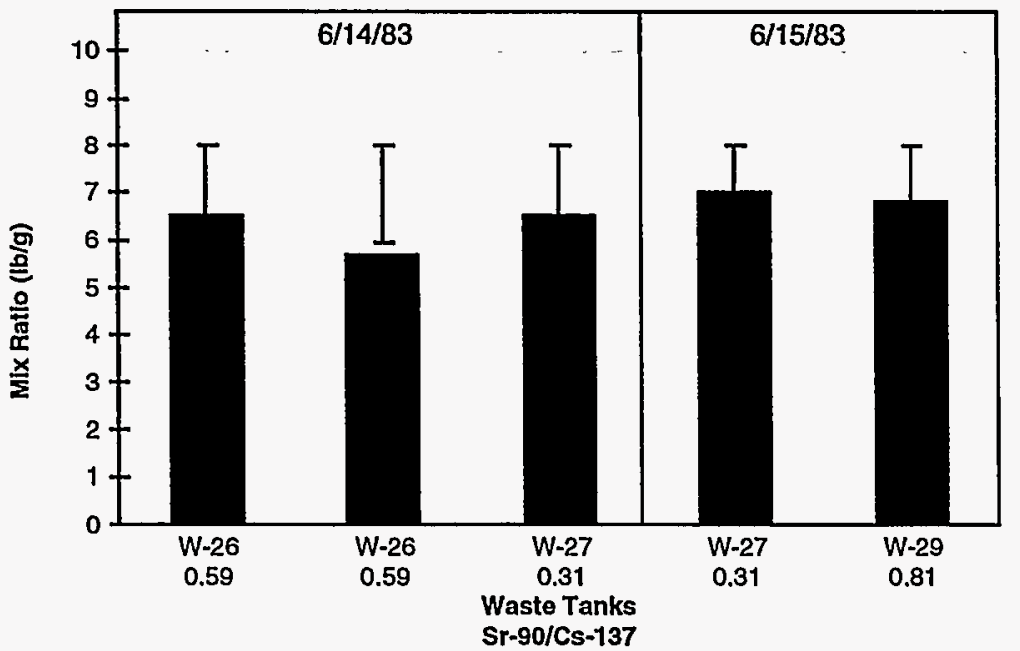

W. Waste Injection SI-7
Slot No. $2(1005 \mathrm{ft},-221 \mathrm{ft})$

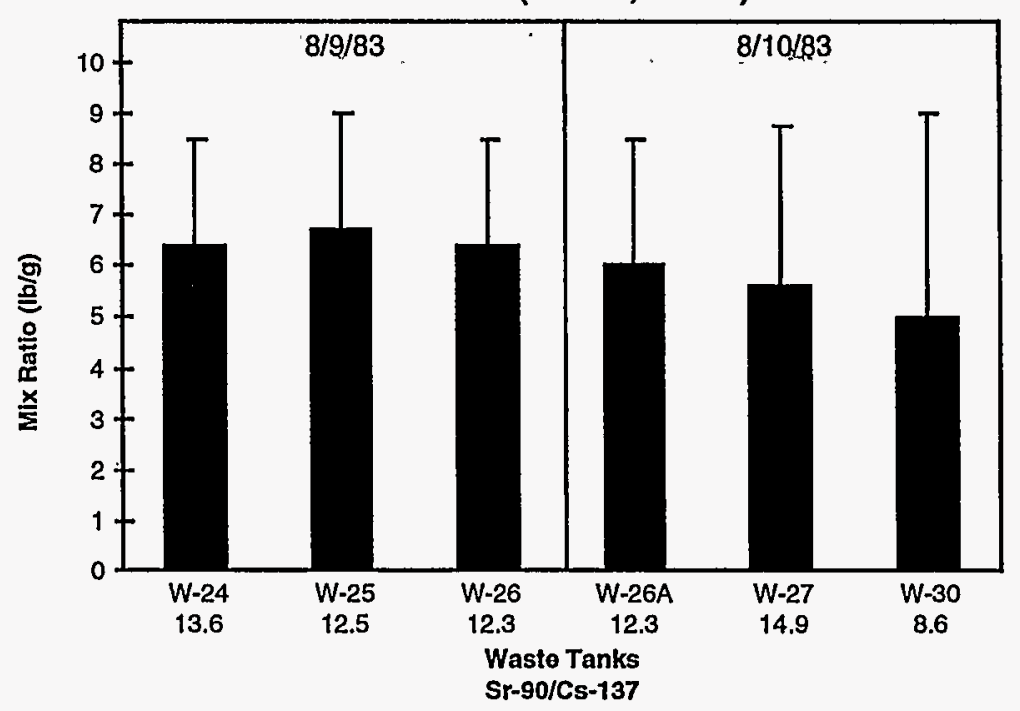

Predominantly Sr-90 Predominantly Cs-137

Fig. 4.17. Summary of desired and actual waste mix ratios used for injections SI-5, ILW-20, SI-6, and SI-7. 

A.

Waste Injection SI-8

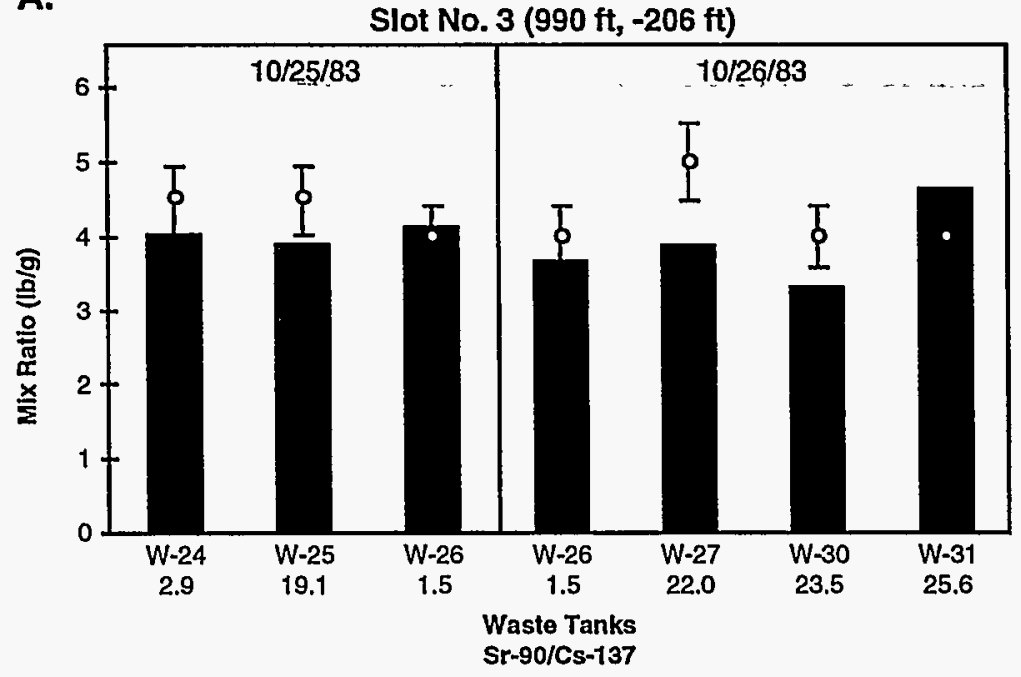

c.

Waste Injection SI-10

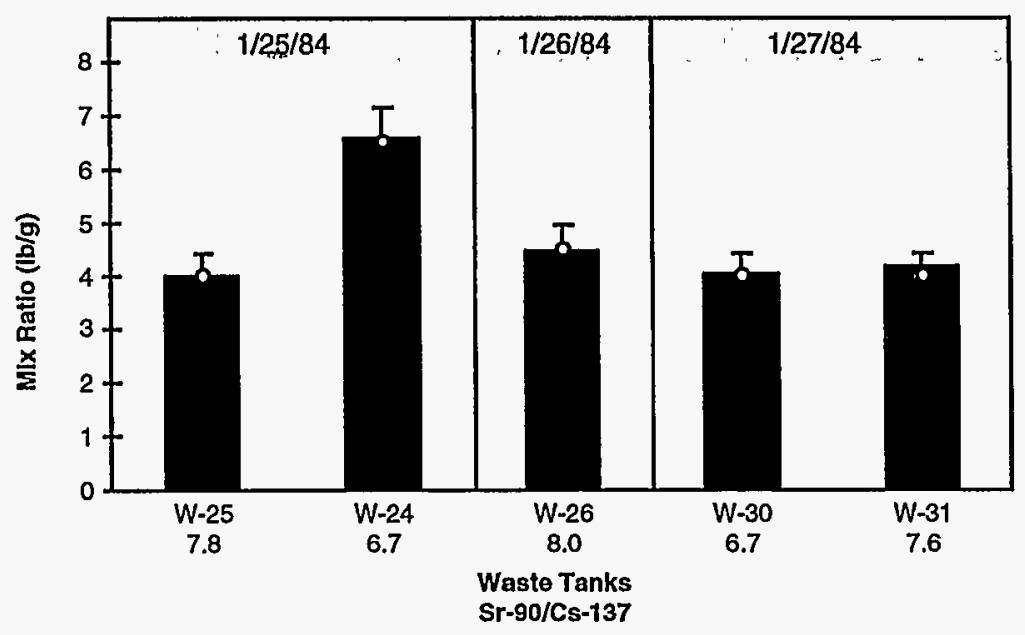

Legend: I Desired Mlx Ratio Range

․ $10 \%$ Error Bar on Desired Mix Ratlo

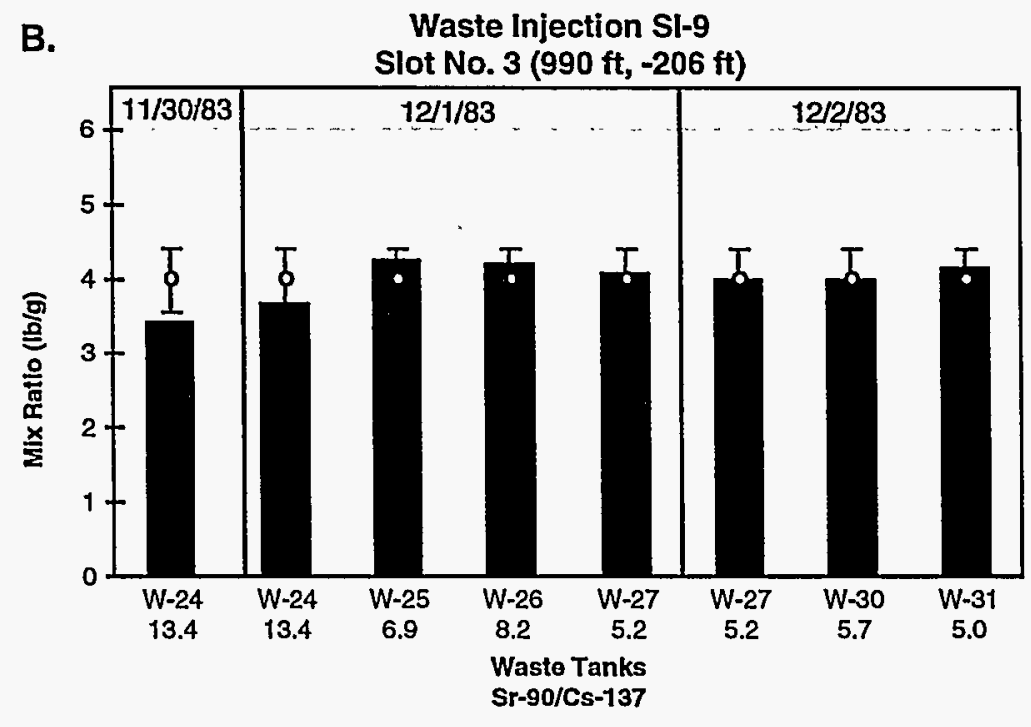

D.

Waste Injection ILW-21

Slot No. 3 (990 ft, $-206 \mathrm{ft}$ )

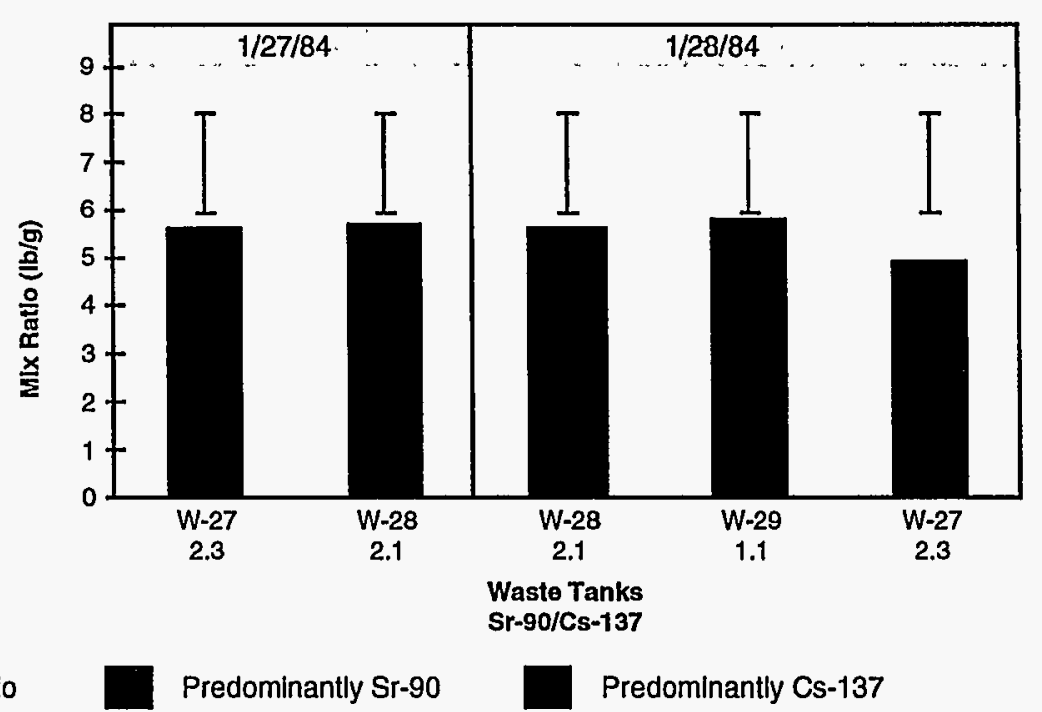

Fig. 4.18. Summary of desired and actual waste mix ratios used for injections SI-8, SI-9, SI-10, and ILW-21. 

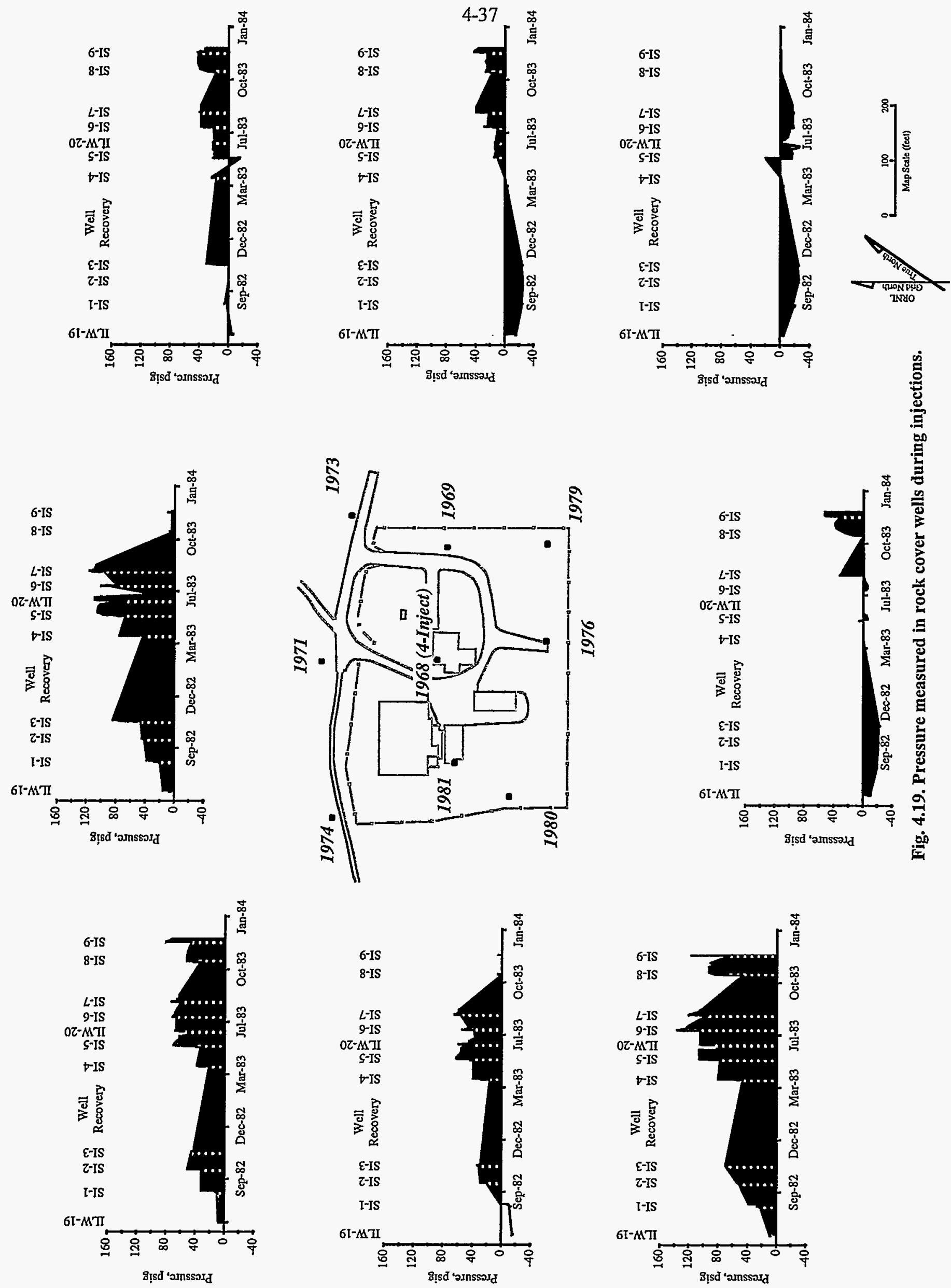

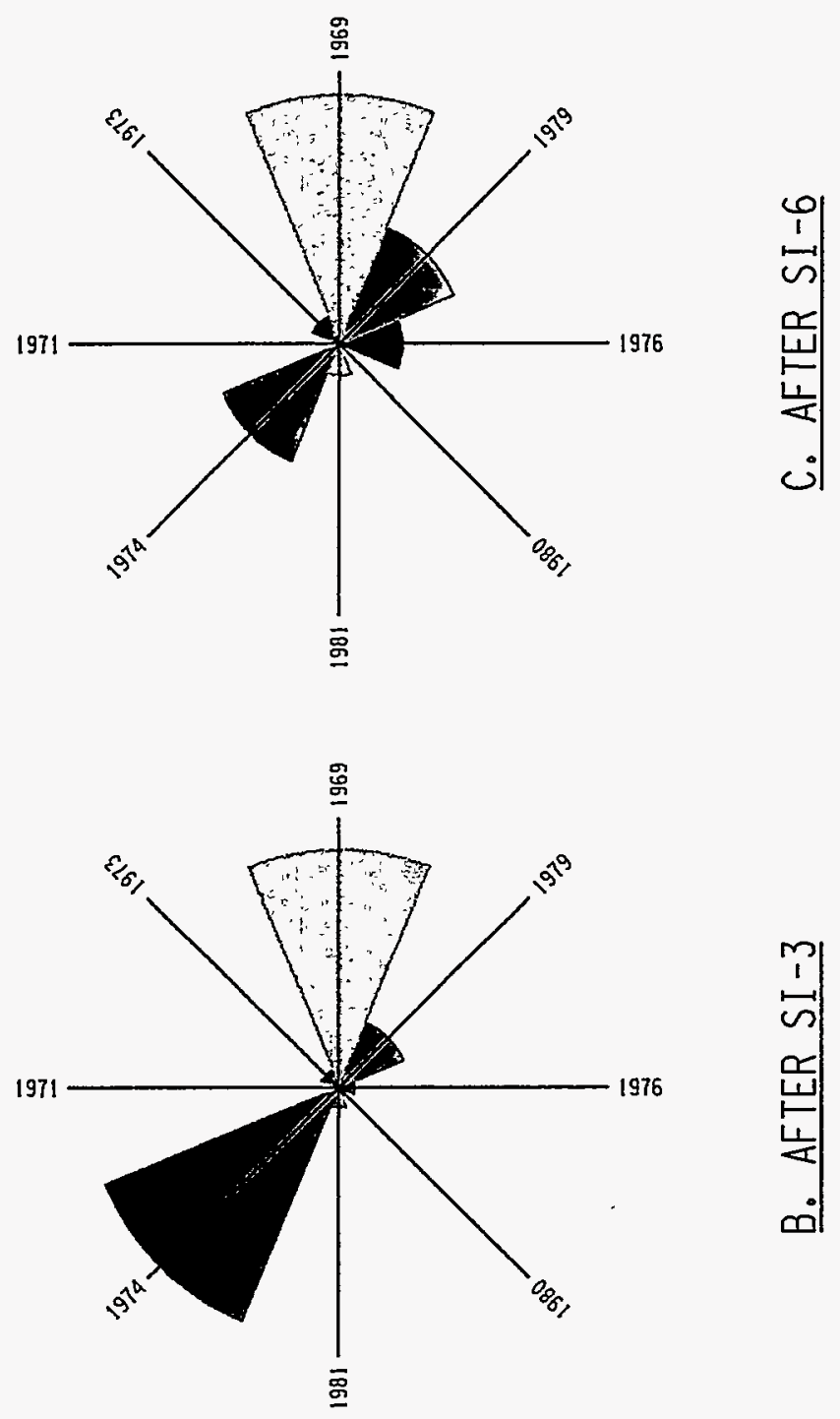

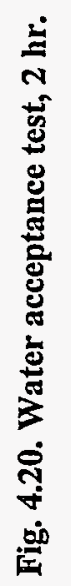
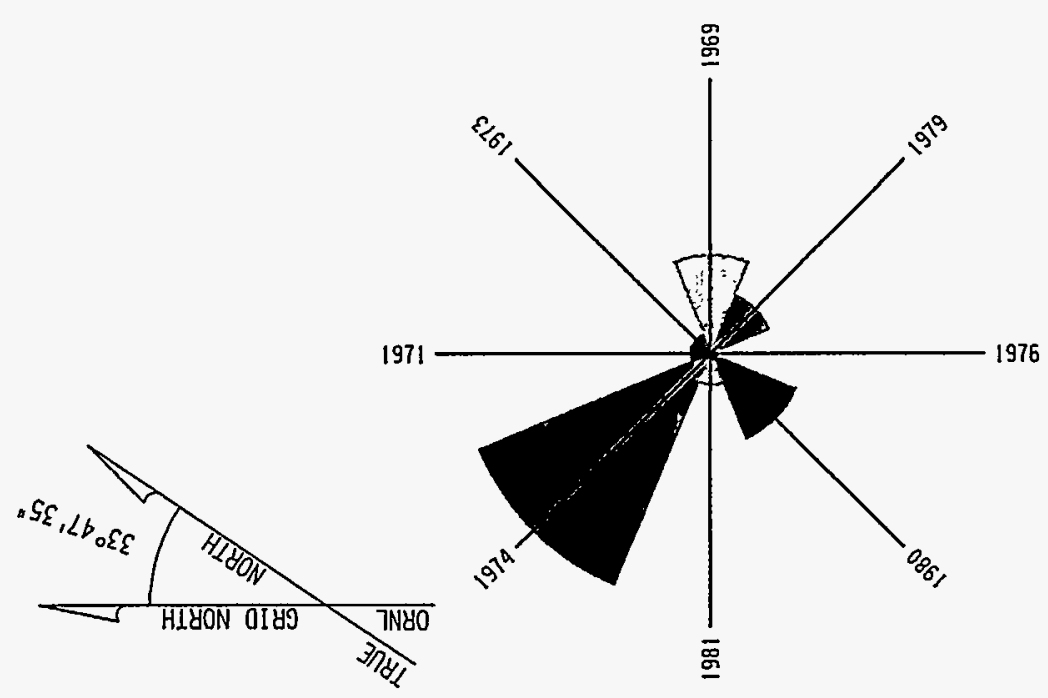

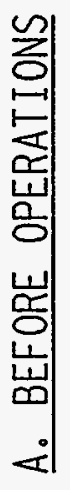

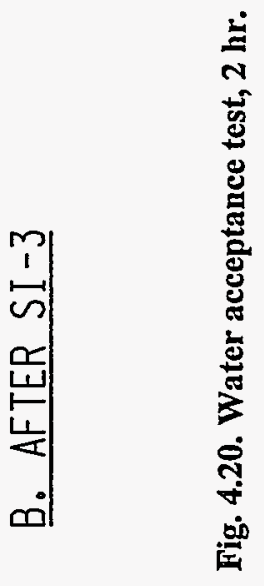



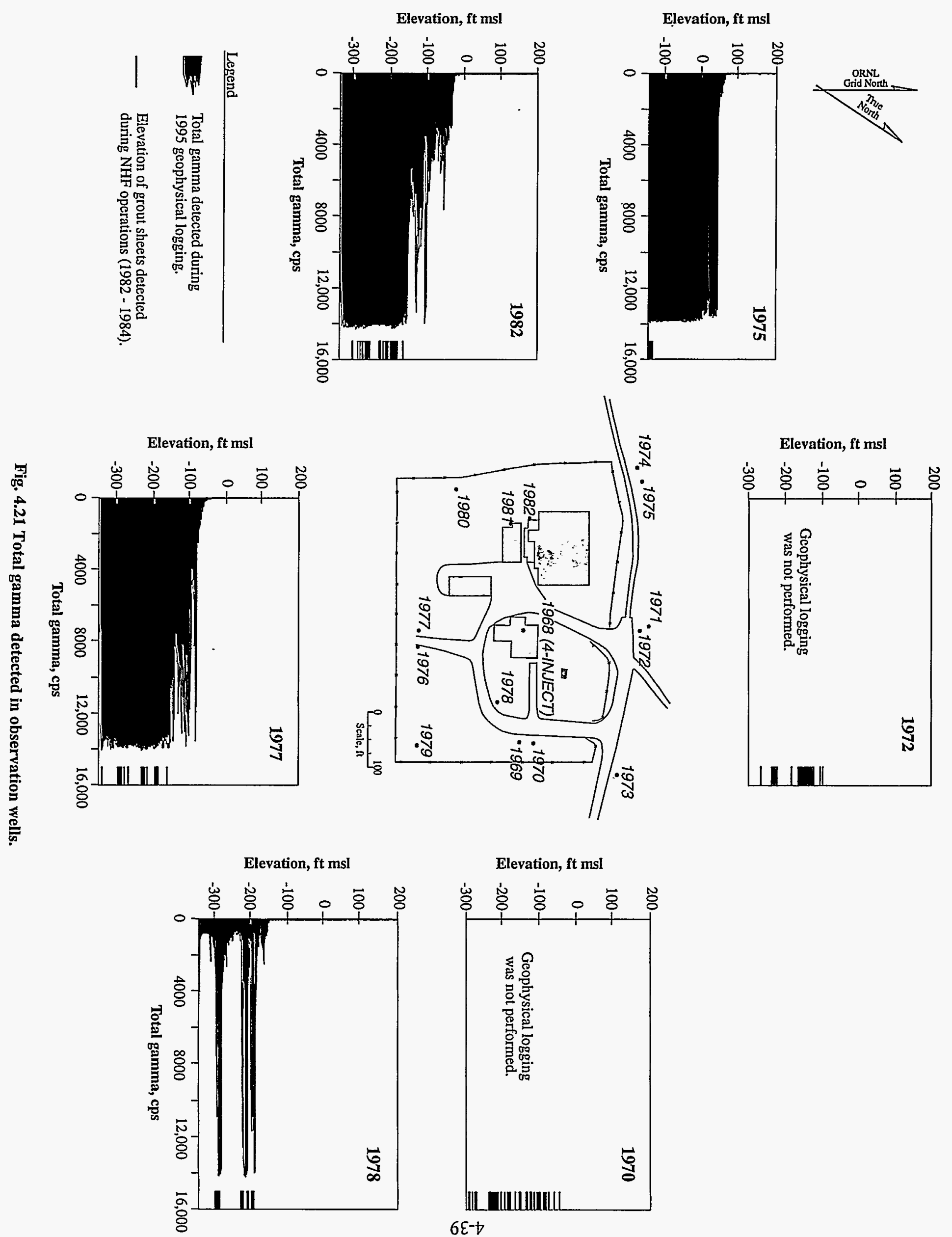

Elevation, $\mathrm{ft}$ msl

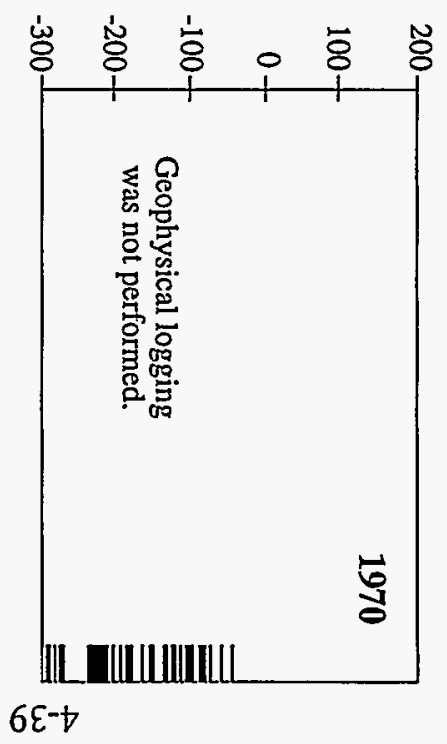




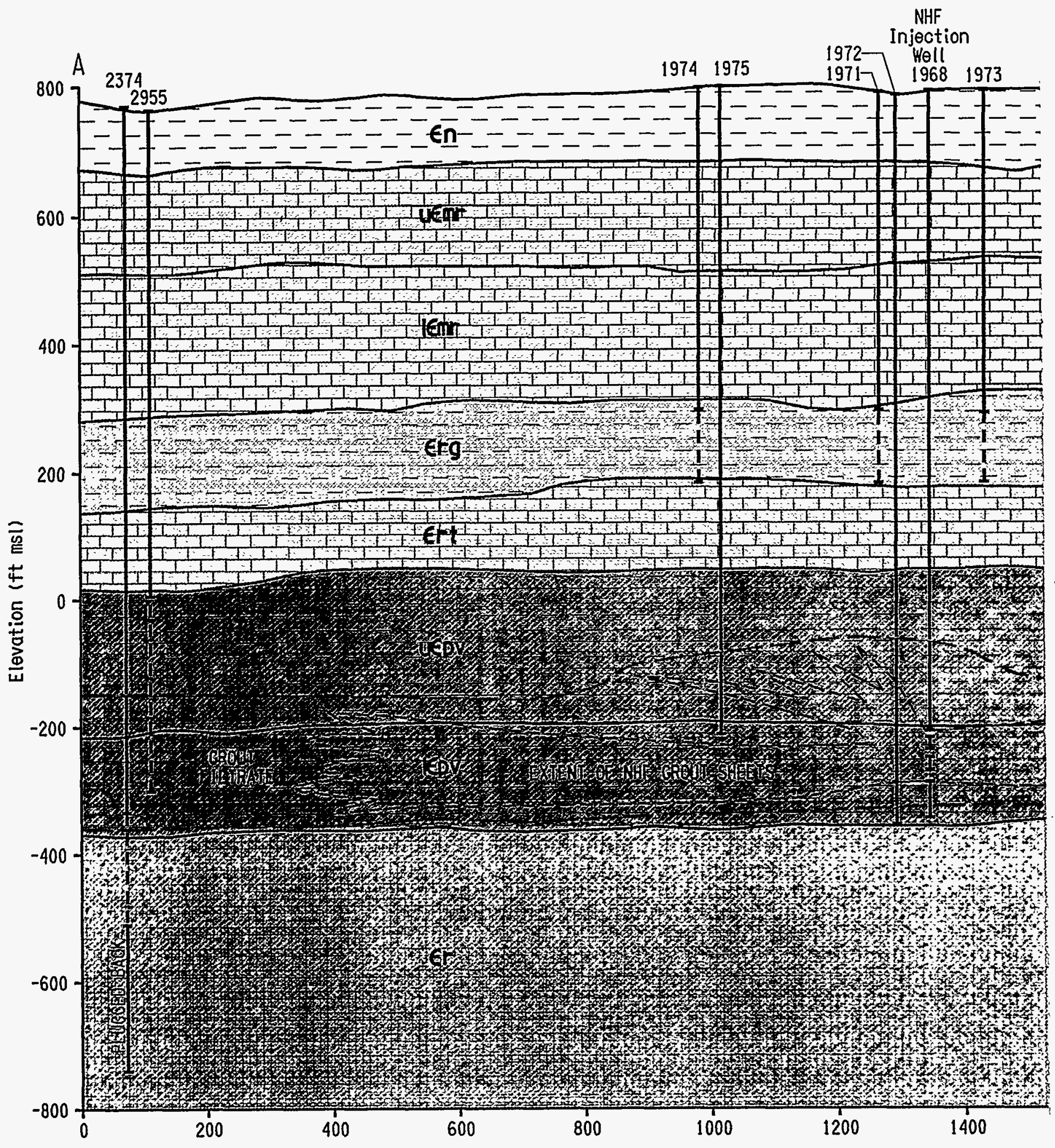

Distance $(\mathrm{ft})$ 

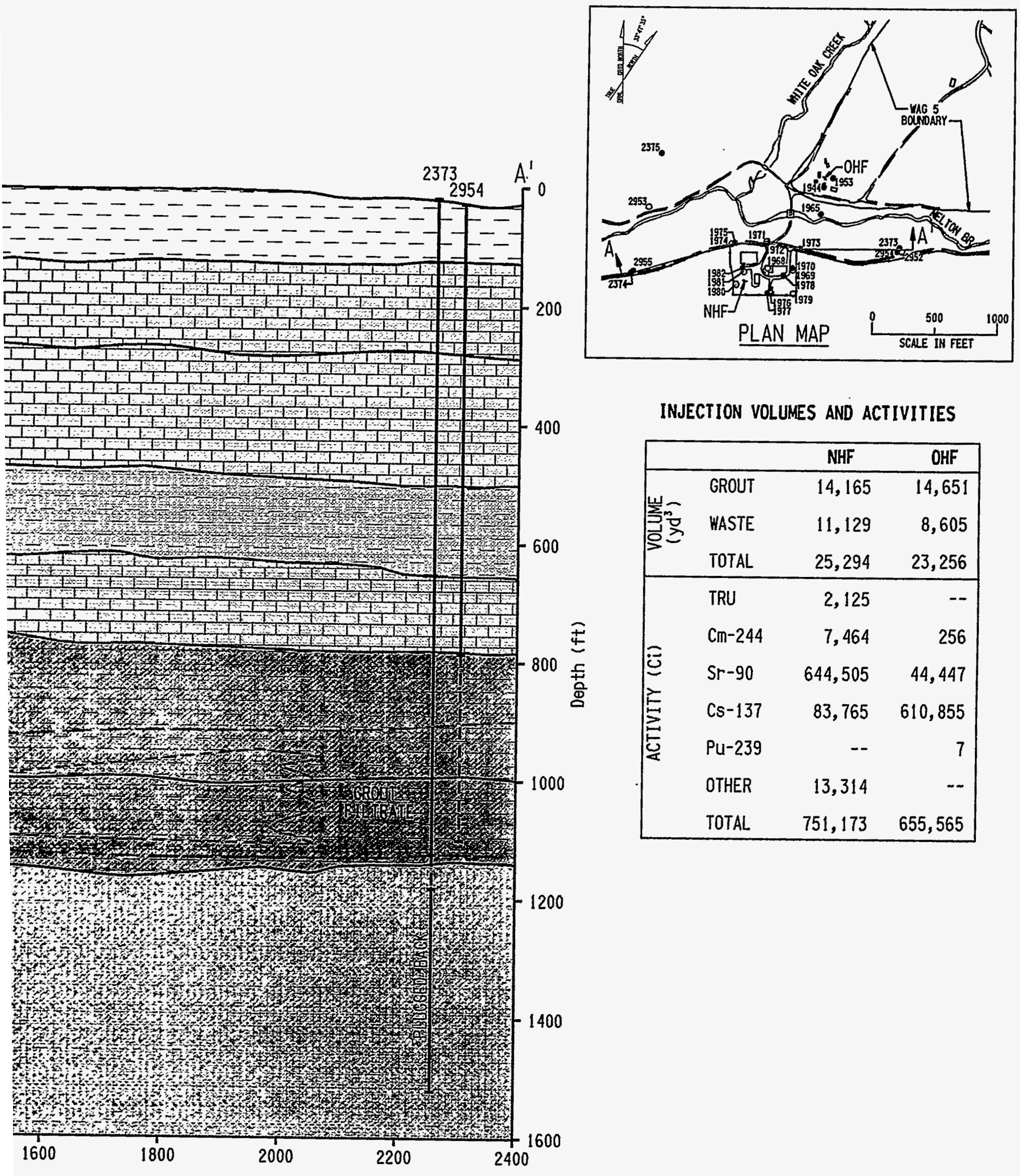

INJECTION VOLUMES AND ACTIVITIES

\begin{tabular}{|c|c|c|c|}
\hline & & NHF & OHF \\
\hline \multirow{3}{*}{ 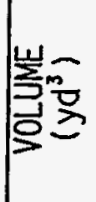 } & GROUT & 14,165 & 14,651 \\
\hline & WASTE & 11,129 & 8,605 \\
\hline & TOTAL & 25,294 & 23,256 \\
\hline \multirow{7}{*}{$\mid \begin{array}{l}\text { 总 } \\
\text { 点 } \\
\text { 点 }\end{array}$} & TRU & 2,125 & -- \\
\hline & $\mathrm{Cm}-244$ & 7,464 & 256 \\
\hline & $S r-90$ & 644,505 & 44,447 \\
\hline & Cs -137 & 83,765 & 610,855 \\
\hline & $\mathrm{Pu}-239$ & -- & 7 \\
\hline & OTHER & 13,314 & -- \\
\hline & TOTAL & 751,173 & 655,565 \\
\hline
\end{tabular}

Fig. 4.22. Extent of grout sheets in the

Pumpkin Valley Shale (A-A). 
(ft) eoupfs!o

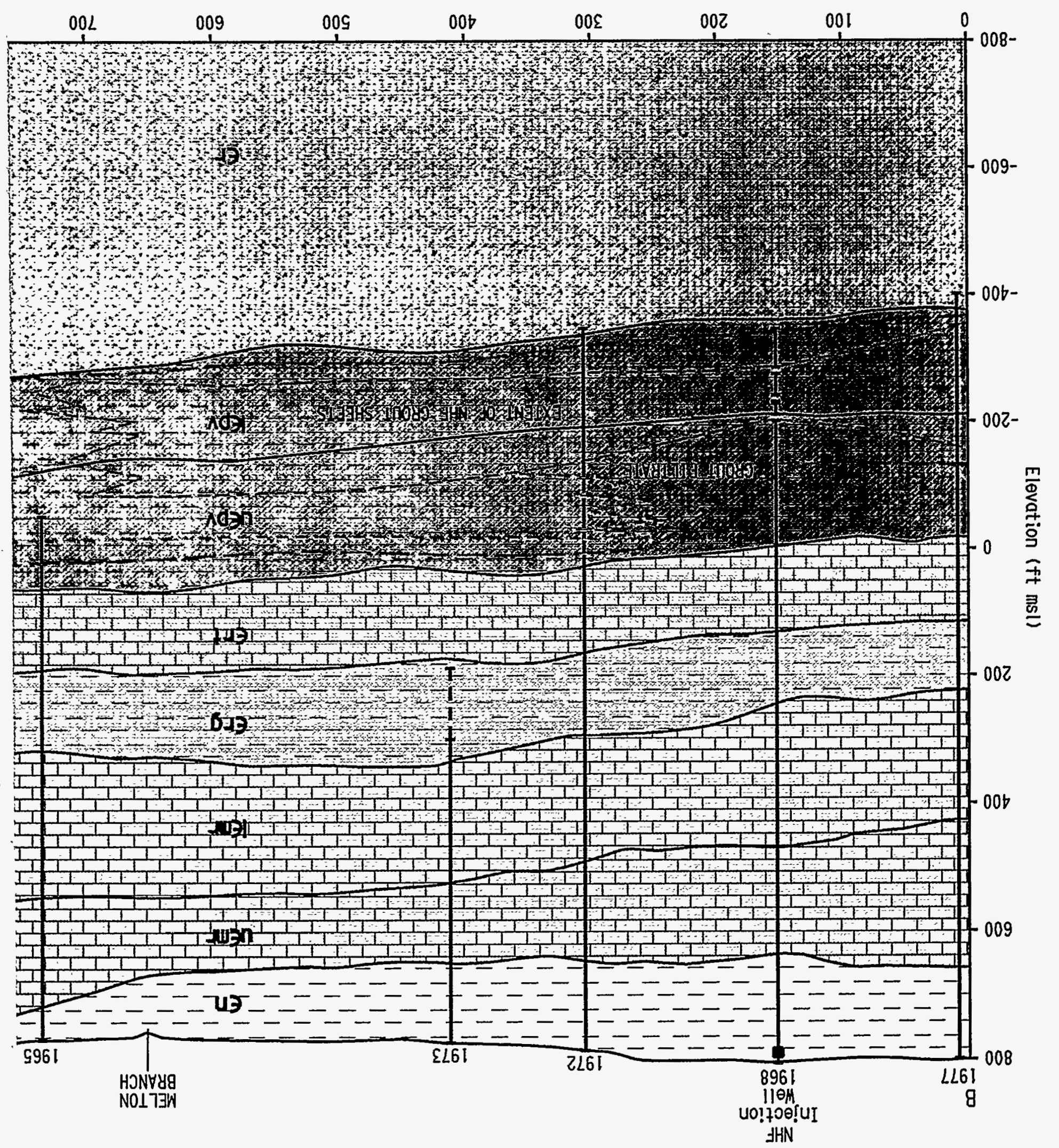



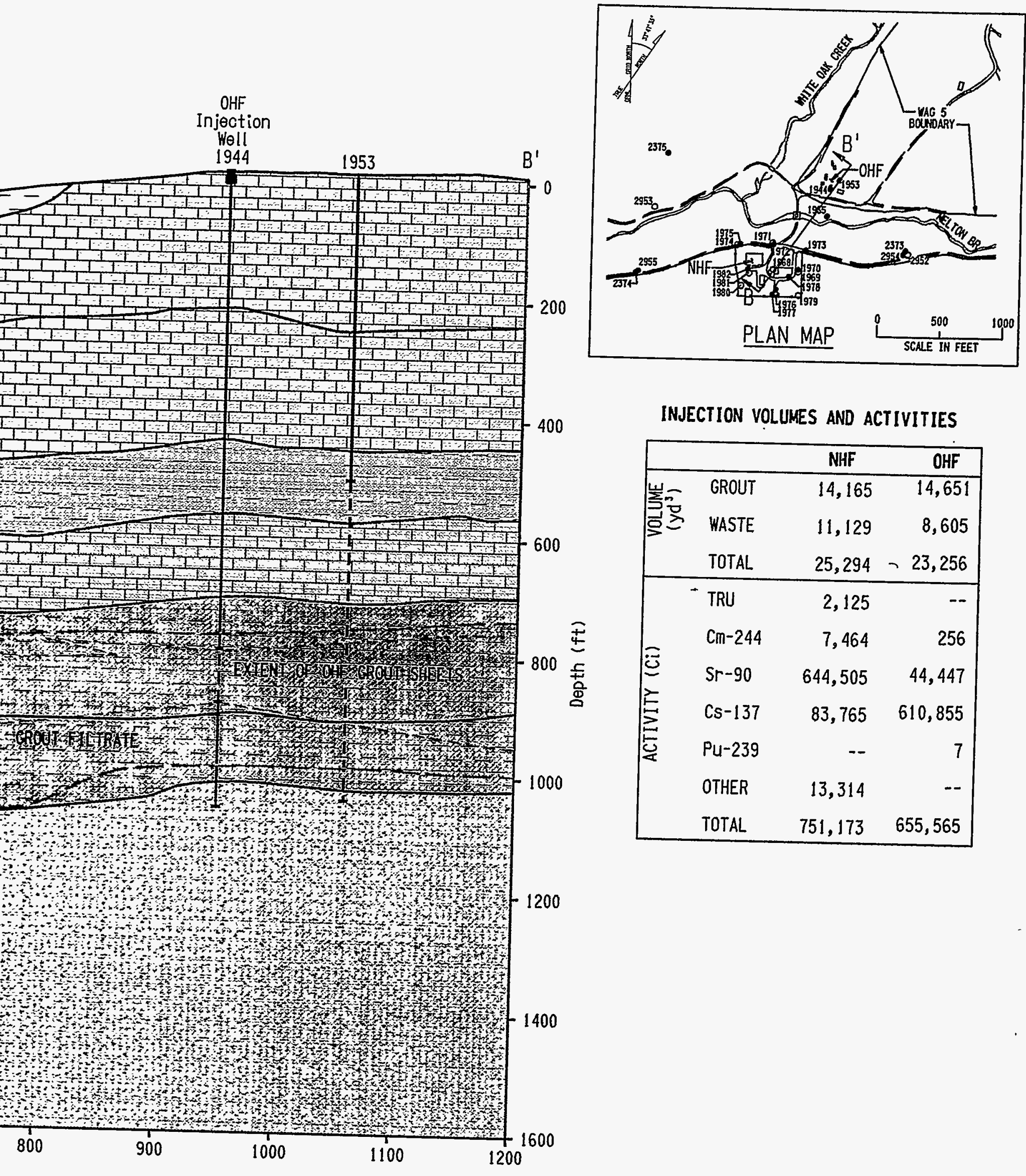

\section{INJECTION VOLUMES AND ACTIVITIES}

\begin{tabular}{|c|c|c|c|}
\hline & & NHF & OHF \\
\hline \multirow{3}{*}{ 崖五 } & GROUT & 14,165 & 14,651 \\
\hline & WASTE & 11,129 & 8,605 \\
\hline & TOTAL & 25,294 & ᄀ 23,256 \\
\hline \multirow{7}{*}{ 导 } & TRU & 2,125 & -- \\
\hline & $\mathrm{Cm}-244$ & 7,464 & 256 \\
\hline & $S r-90$ & 644,505 & 44,447 \\
\hline & Cs -137 & 83,765 & 610,855 \\
\hline & Pu-239 & -- & 7 \\
\hline & OTHER & 13,314 & -- \\
\hline & TOTAL & 751,173 & 655,565 \\
\hline
\end{tabular}

Fig. 4.23. Extent of grout sheets in the

Pumpkin Valley Shale (B-B). 

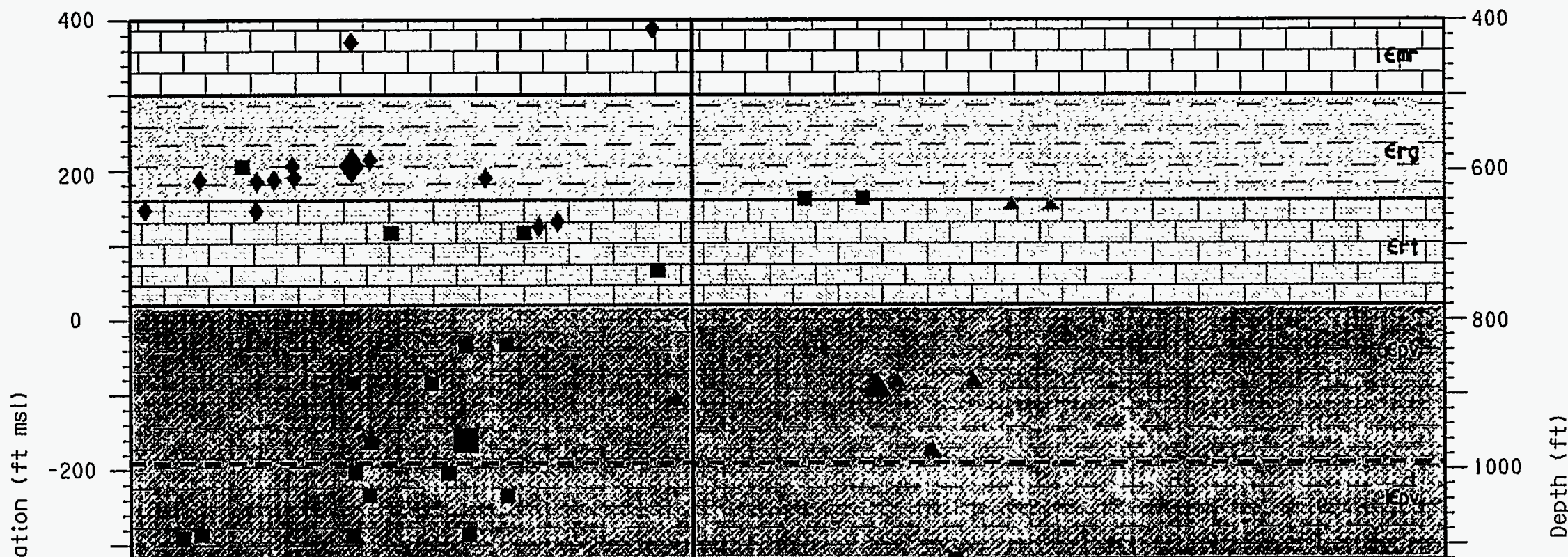

$4 G \quad 10 \quad 10 f 067.06 N$

$15 / 96$ 


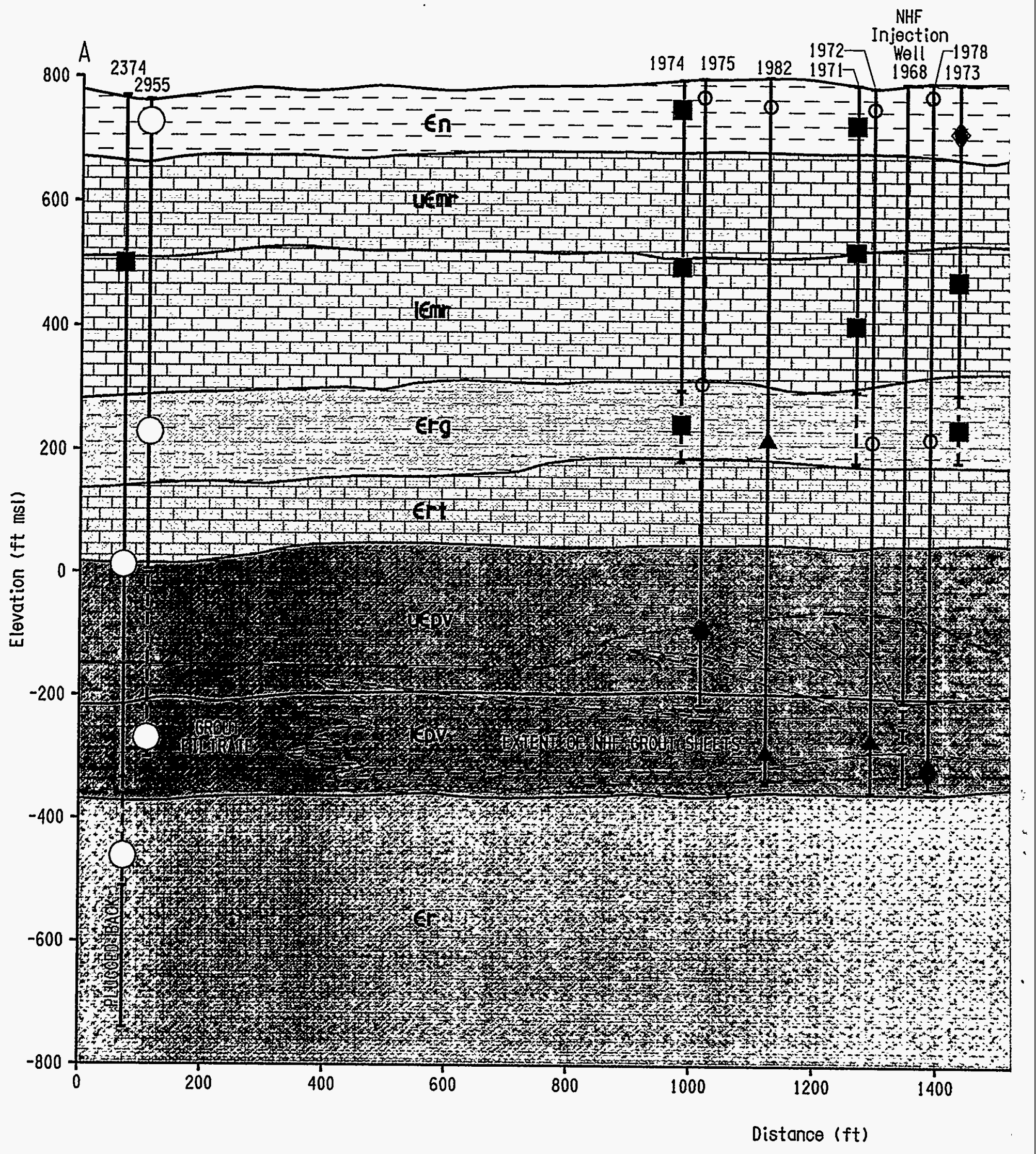




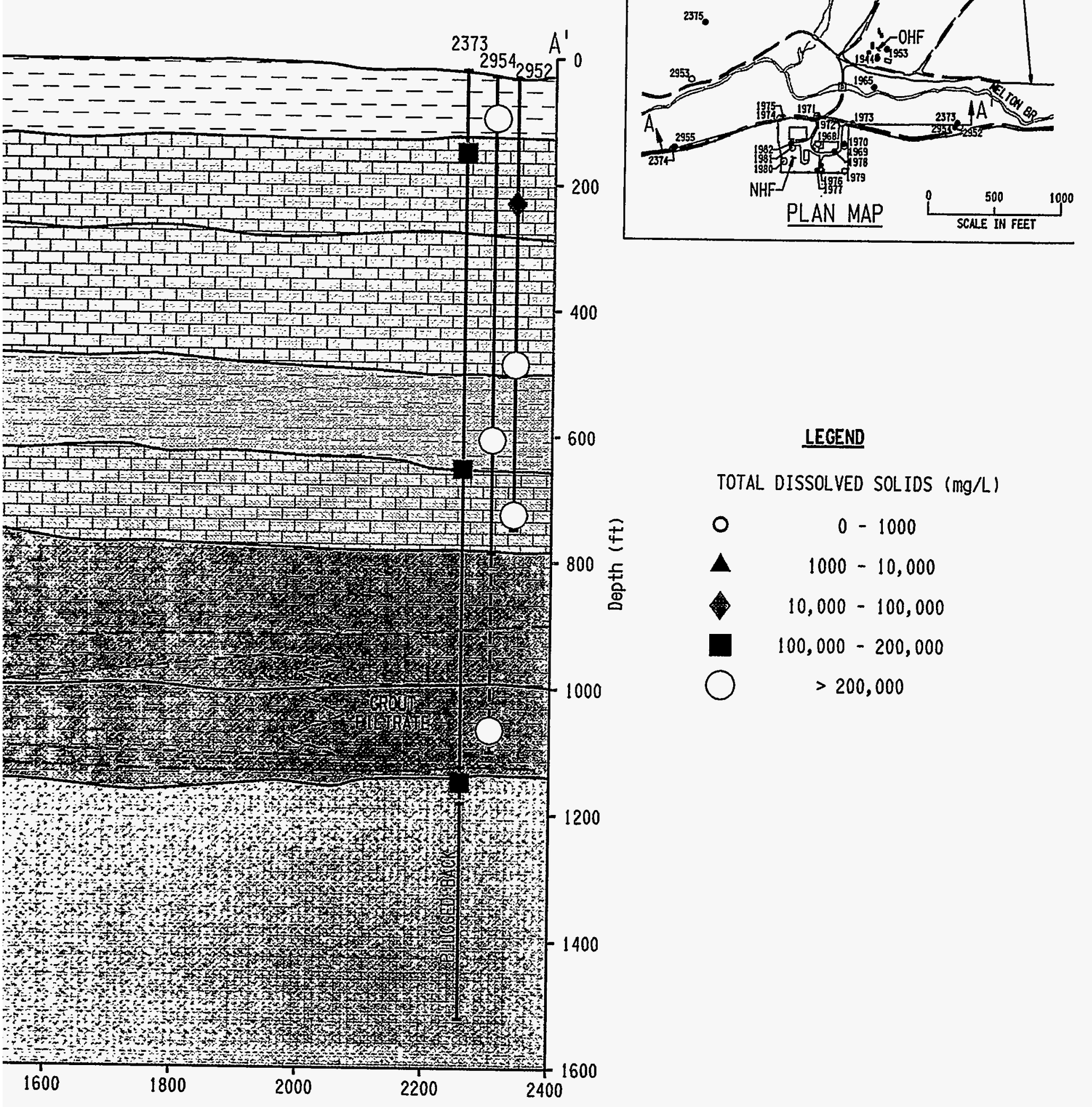

Fig. 4.25. Total dissolved solids in selected New Hydrofracture Facility wells. 


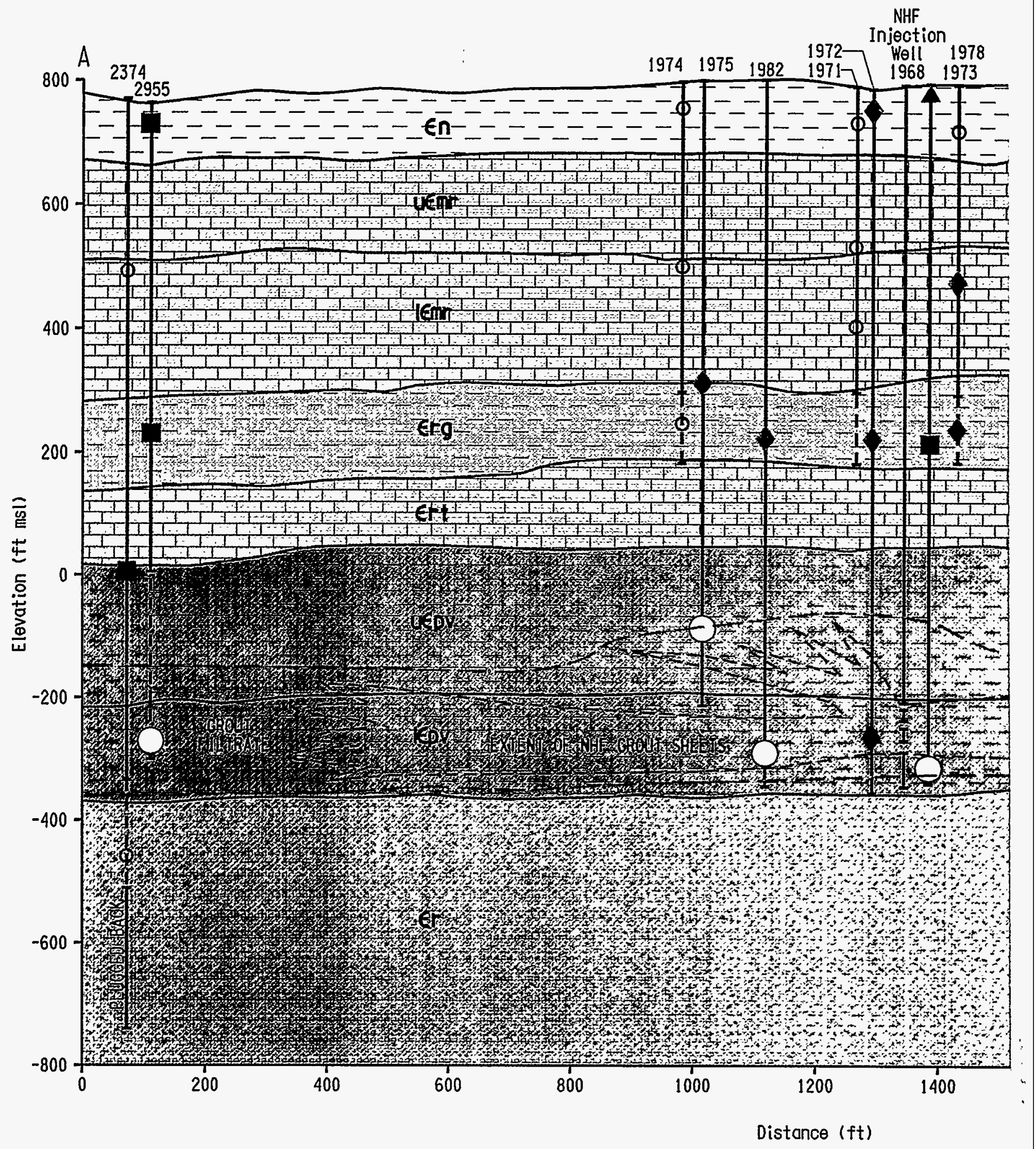




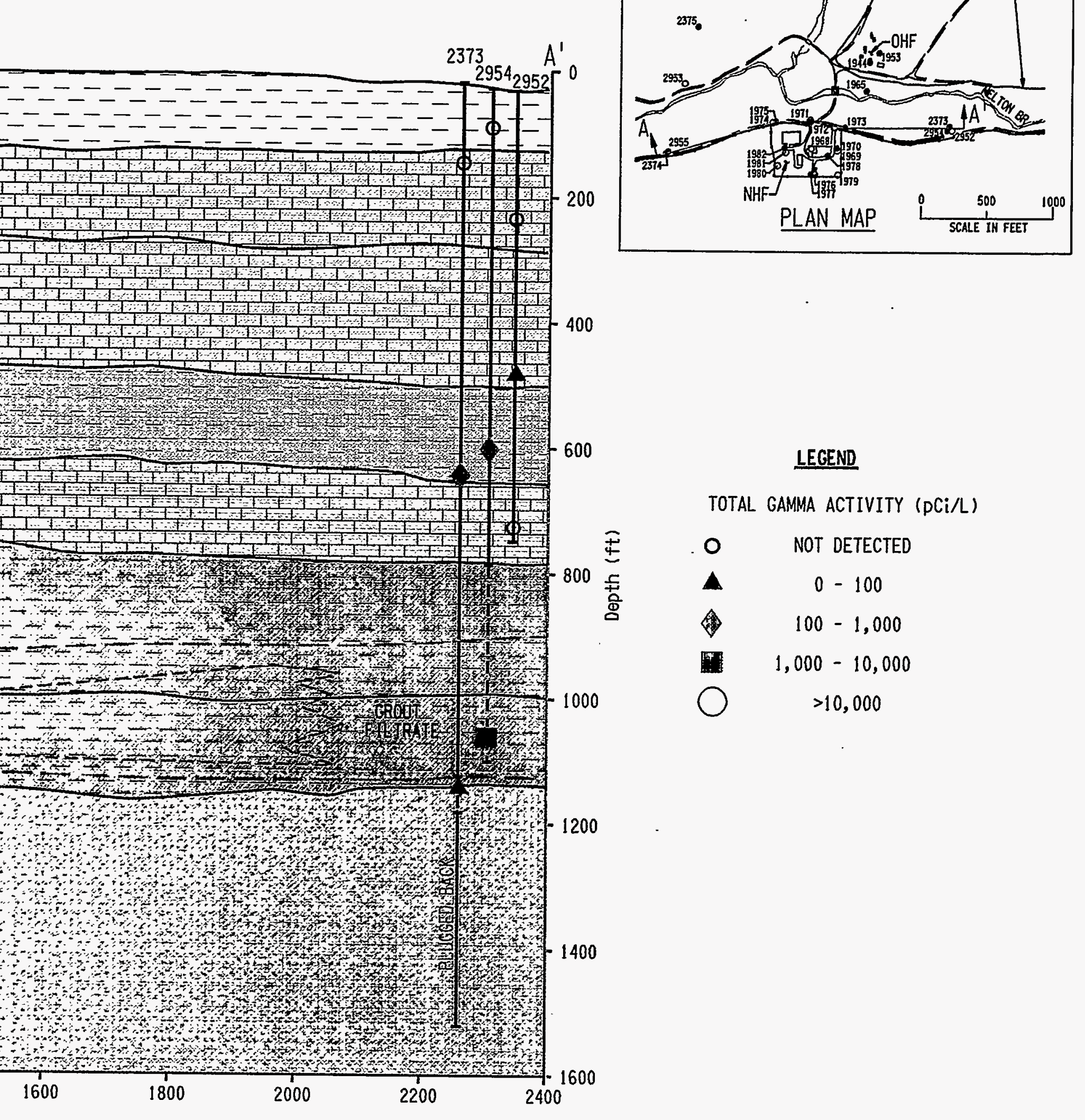

Fig. 4.26. Total gamma activity in selected New Hydrofracture Facility wells. 


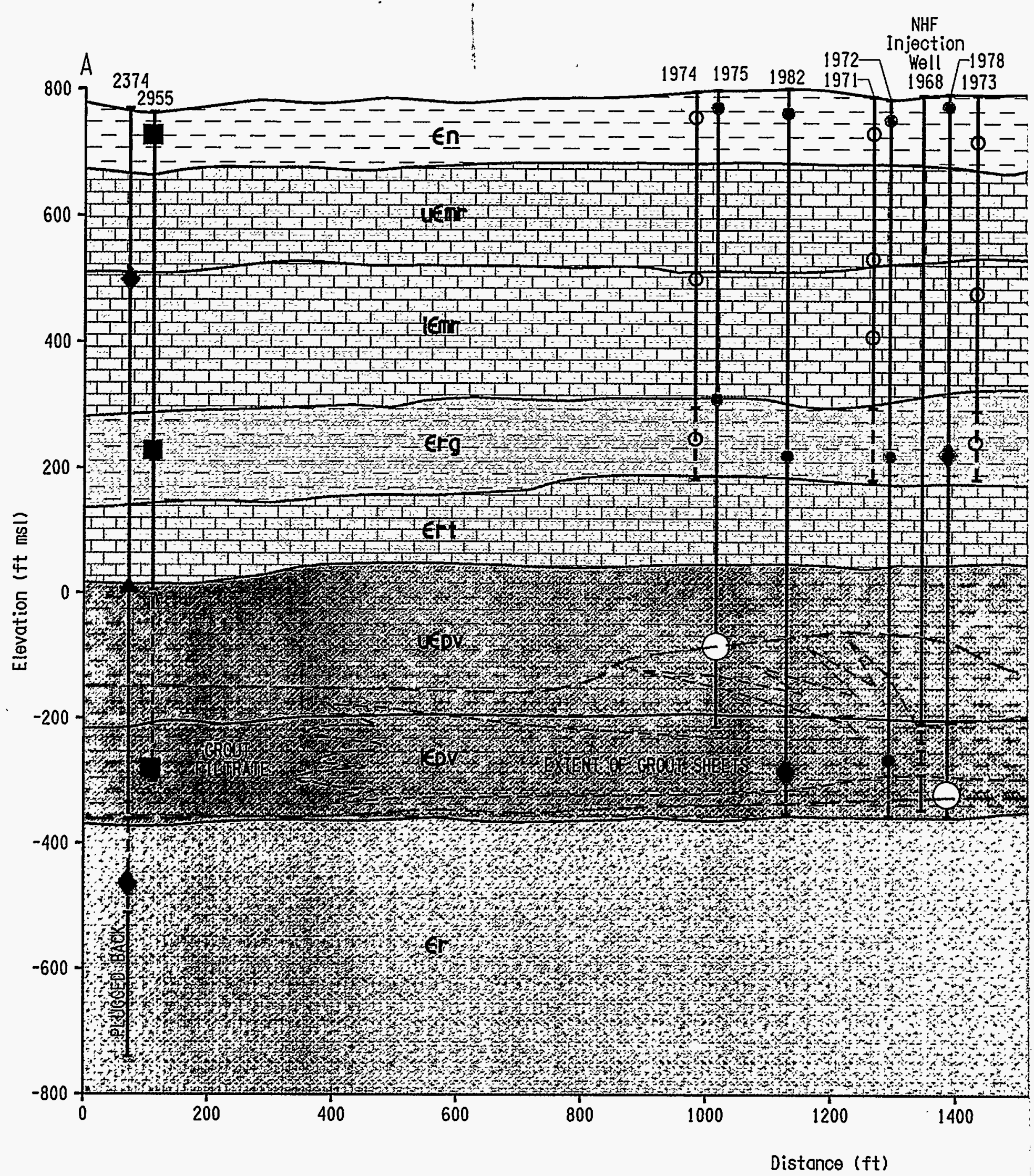




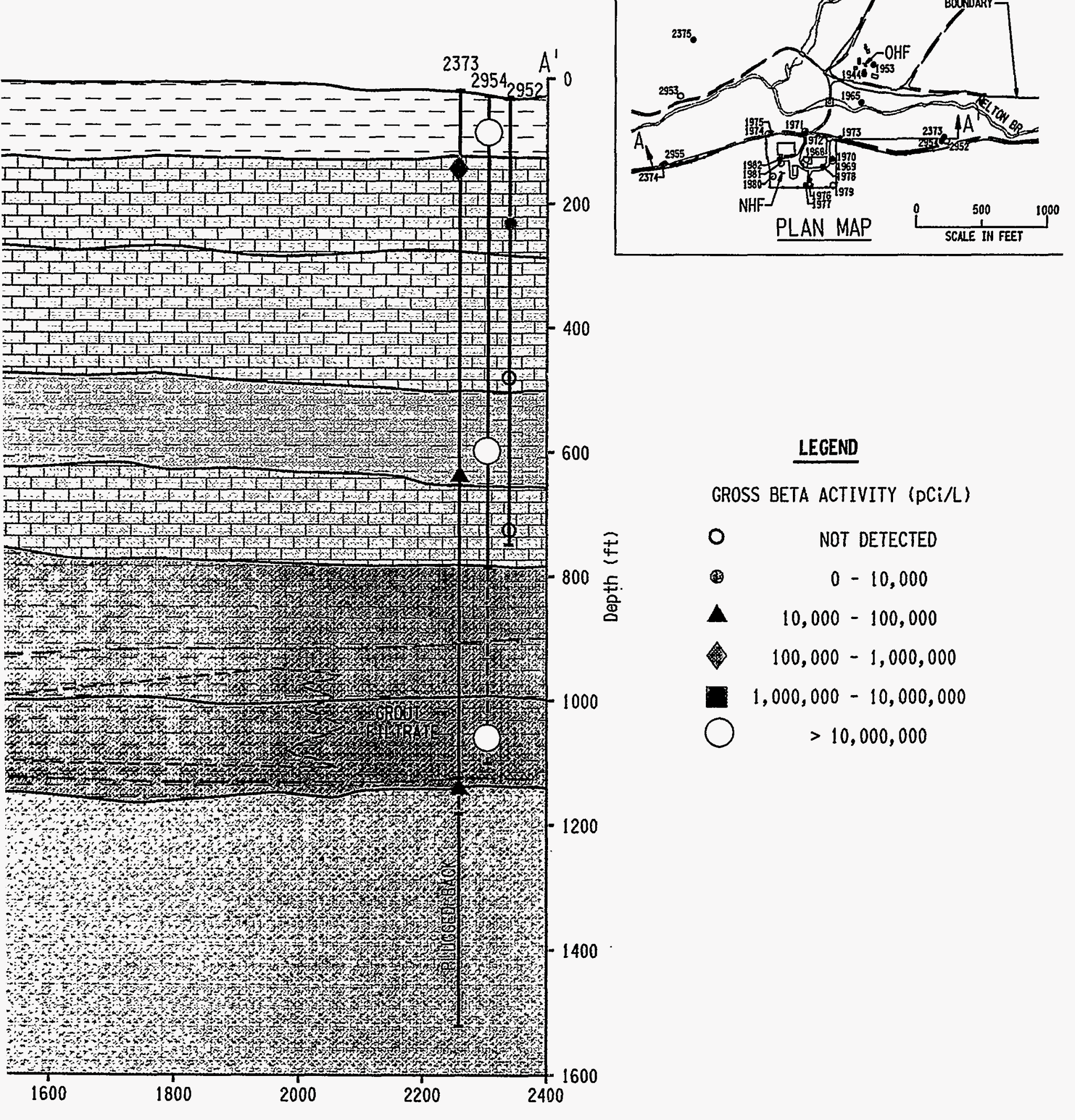

Fig. 4.27. Gross beta activity in selected New Hydrofracture Facility wells. 

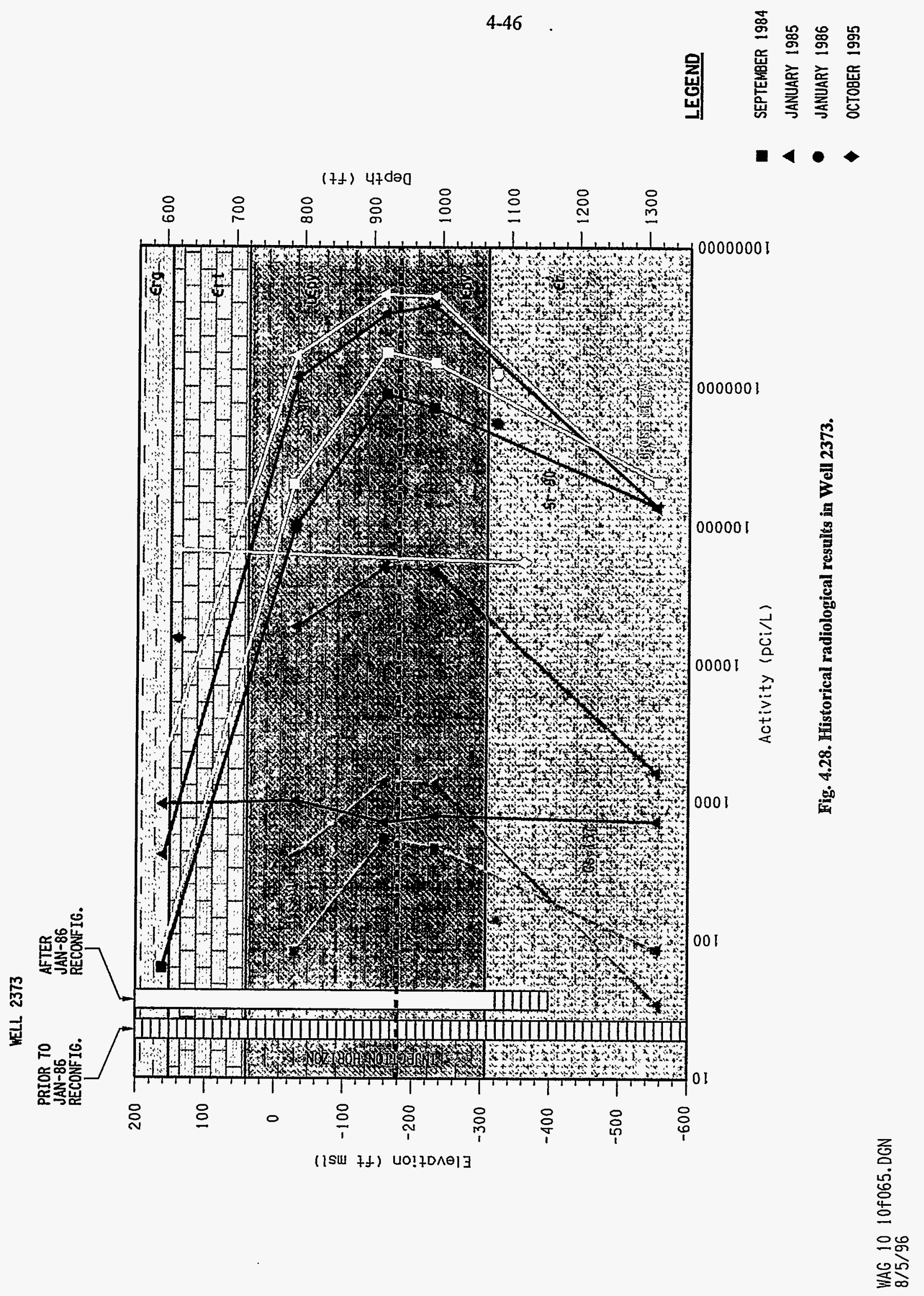
WELL 2374

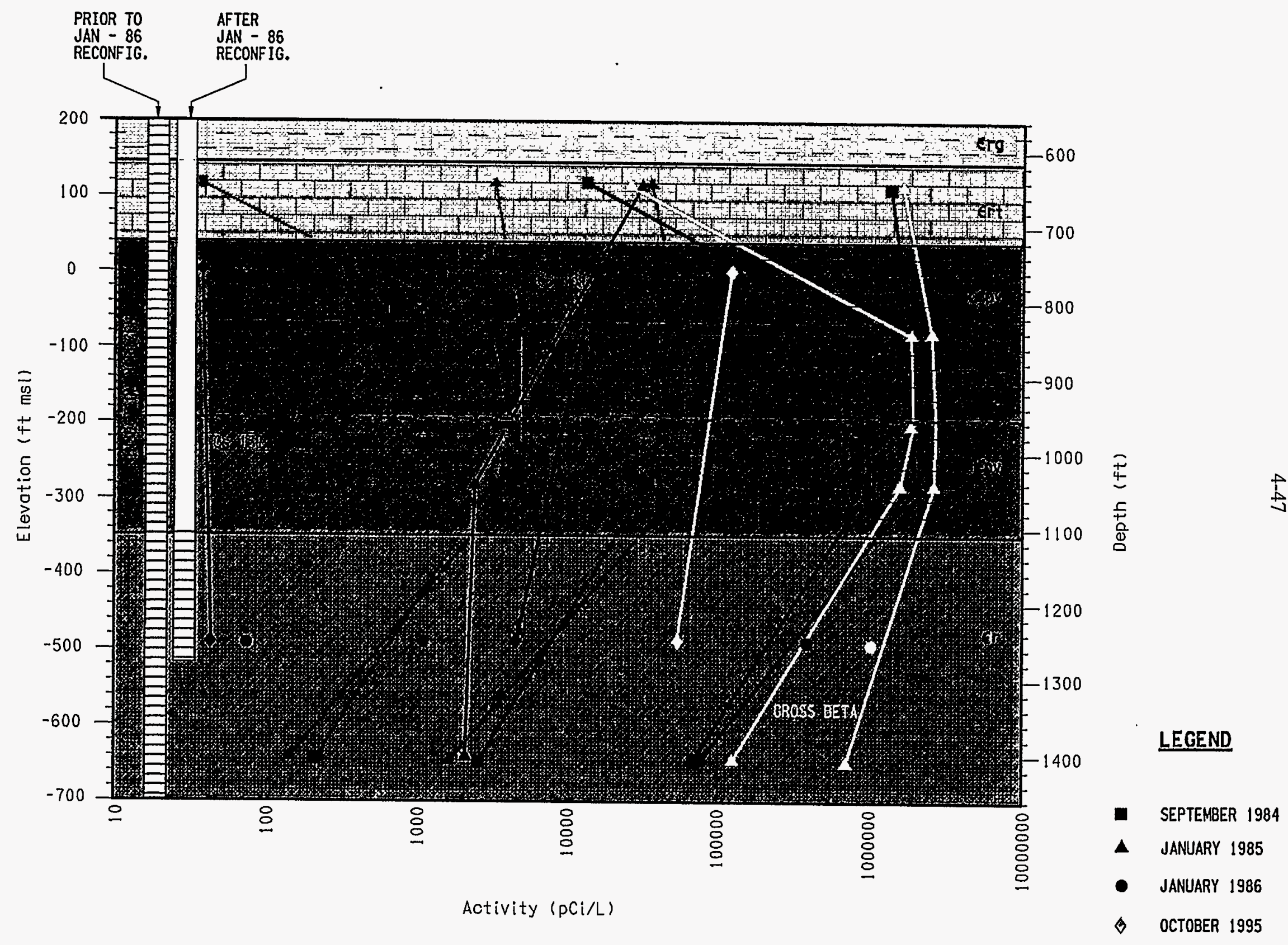

Fig. 4.29. Historic radiological results in Well 2374. 


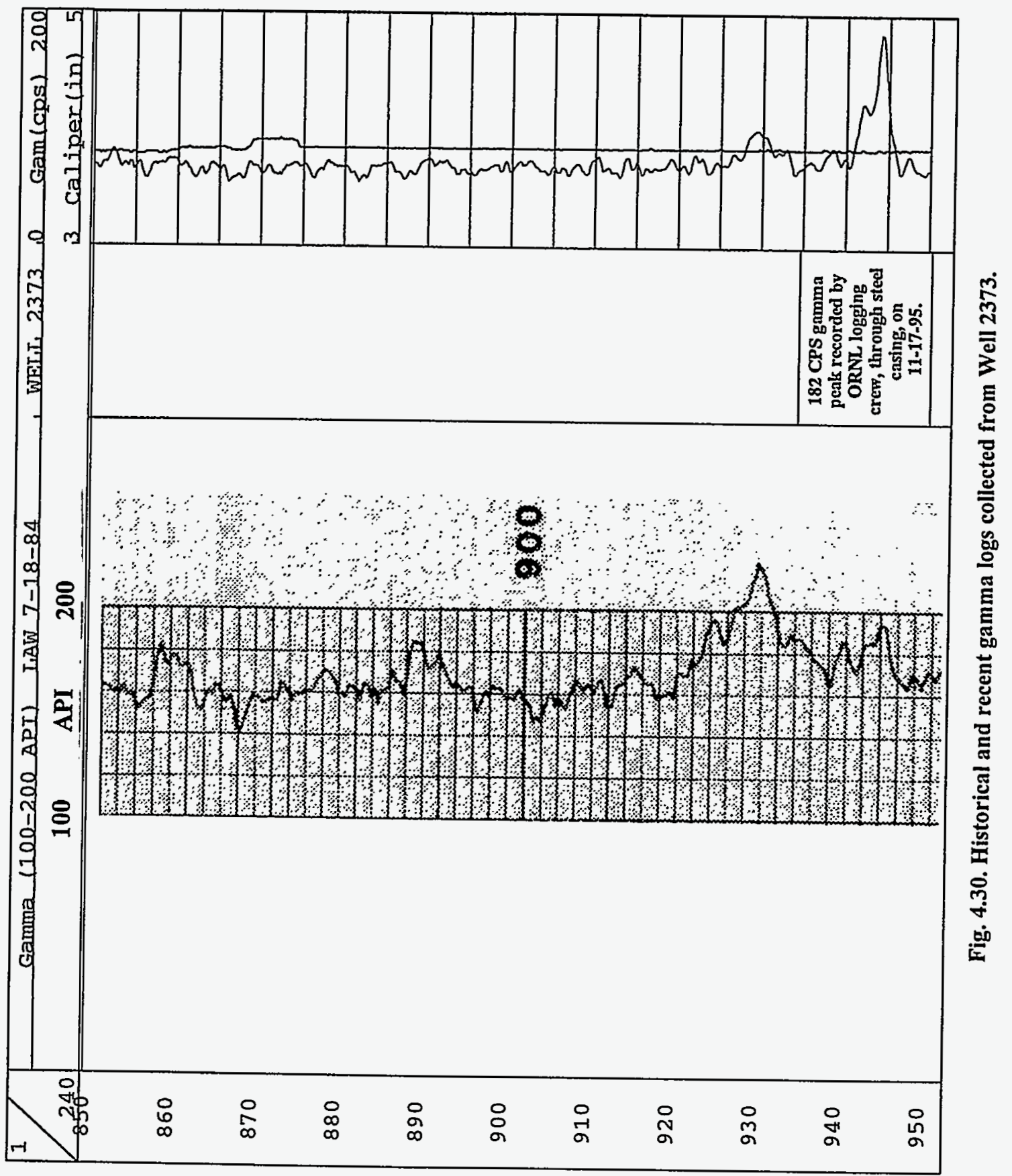




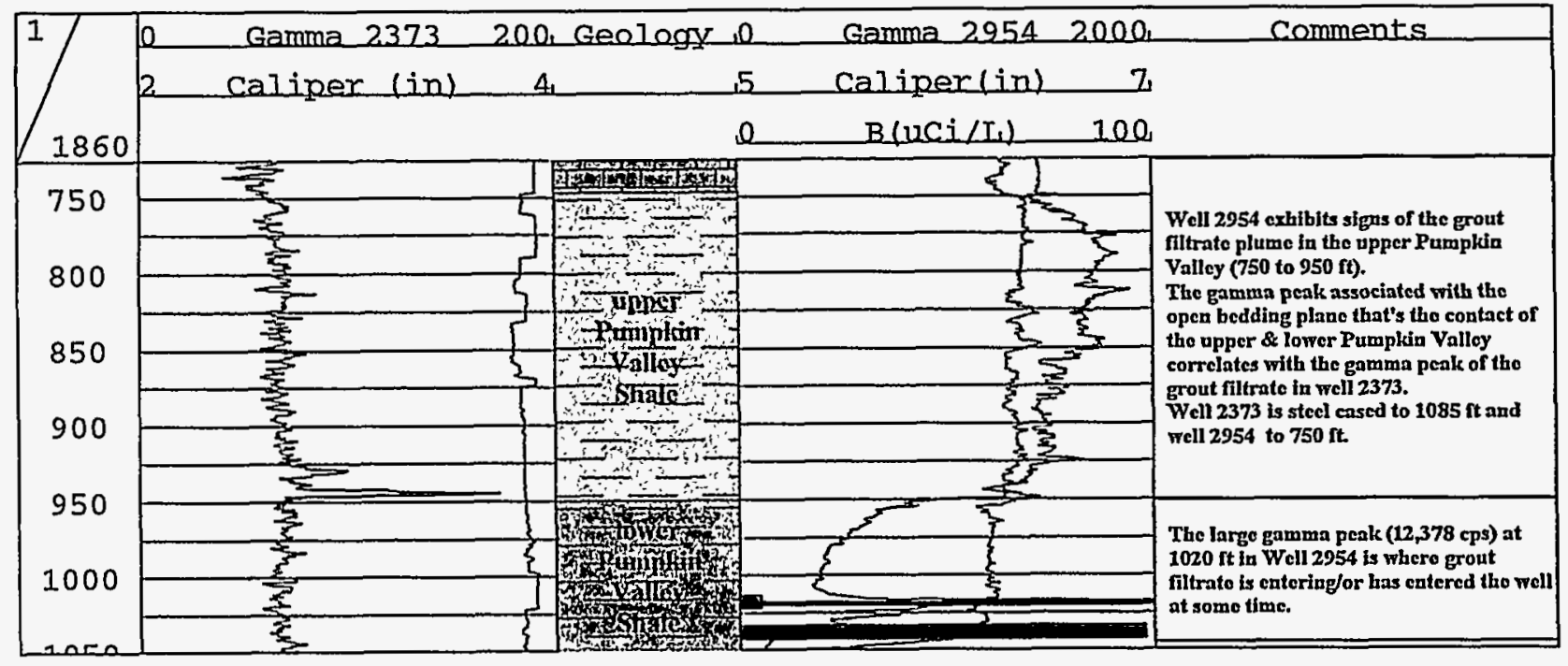

Fig. 4.31. Comparison of gamma logs from Well 2373 and Well 2954. 


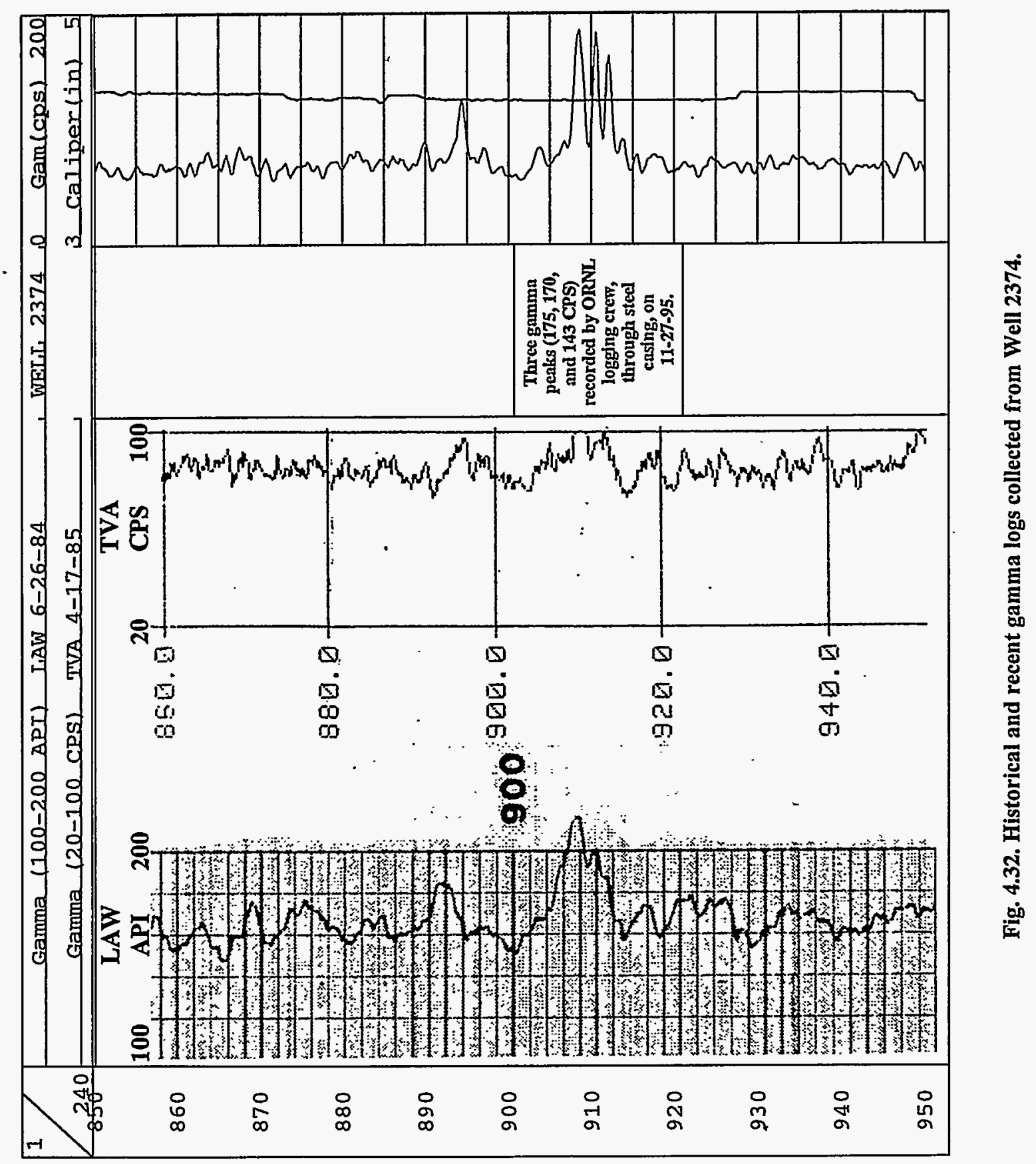


Table 4.1. Close Support Laboratory analytical data summary for $\mathrm{pH}$, alkalinity, total dissolved solids, and total suspended solids

\begin{tabular}{|c|c|c|c|c|c|c|c|}
\hline \multirow[b]{2}{*}{ Station } & \multicolumn{2}{|c|}{ Sample } & \multicolumn{2}{|c|}{$\mathrm{pH}$} & \multirow{2}{*}{$\begin{array}{c}\text { Alkalinity } \\
\left(\mathrm{mg} \mathrm{CaCO}_{3} / \mathrm{L}\right) \\
\end{array}$} & \multirow{2}{*}{$\begin{array}{c}\text { TDS } \\
(\mathrm{mg} / \mathrm{L})\end{array}$} & \multirow{2}{*}{$\begin{array}{c}\text { TSS } \\
(\mathrm{mg} / \mathrm{L})\end{array}$} \\
\hline & Depth, ft & Elev., ft & field & laboratory & & & \\
\hline \multicolumn{3}{|c|}{ 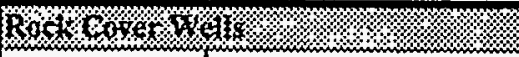 } & (3) & sis & & & ঋ) \\
\hline \multirow{3}{*}{$\begin{array}{c}1969 \\
(4 \mathrm{E}-200 \mathrm{RC})\end{array}$} & 96 & 693 & 6.00 & 4.44 & - & 147,355 & 200 \\
\hline & 339 & 450 & 5.69 & 4.62 & - & 167,258 & 70 \\
\hline & 625 & 164 & 5.12 & 4.45 & - & 180,688 & 210 \\
\hline \multirow{3}{*}{$\begin{array}{c}1971 \\
(4 \mathrm{~N}-200 \mathrm{RC})\end{array}$} & 62 & 706 & 5.48 & 4.67 & - & 144,940 & 122 \\
\hline & 261 & 507 & 5.70 & 4.77 & - & 160,794 & 95 \\
\hline & 387 & 381 & 5.58 & 4.24 & - & 162,616 & 140 \\
\hline \multirow{3}{*}{$\begin{array}{c}1973 \\
(4 \mathrm{NE}-280 \mathrm{RC})\end{array}$} & 76 & 689 & 6.76 & 4.36 & - & 73,436 & 46 \\
\hline & 317 & 448 & & 4.08 & - & 140,146 & 84 \\
\hline & 557 & 208 & & 4.32 & - & 155,621 & 110 \\
\hline \multirow{3}{*}{$\begin{array}{c}1974 \\
(4 \mathrm{NW}-340 \mathrm{RC})\end{array}$} & 45 & 724 & 7.39 & 4.92 & - & 152,848 & 107 \\
\hline & 300 & 469 & 6.22 & 4.51 & - & 149,714 & 146 \\
\hline & 555 & 214 & 5.04 & 4.10 & $=$ & 162,658 & 150 \\
\hline \multirow{3}{*}{$\begin{array}{c}1976 \\
(4 \mathrm{~S}-200 \mathrm{RC})\end{array}$} & 105 & 696 & 6.16 & 4.58 & - & 45,092 & 79 \\
\hline & 390 & 411 & 5.37 & 3.61 & - & 207,380 & 139 \\
\hline & 674 & 127 & 5.36 & 3.79 & - & 221,949 & 252 \\
\hline \multirow{3}{*}{$\begin{array}{c}1979 \\
(4 \mathrm{SE}-280 \mathrm{RC})\end{array}$} & 122 & 692 & 6.52 & 5.41 & - & 54,838 & 52 \\
\hline & 398 & 416 & 5.97 & 4.36 & - & 141,989 & 60 \\
\hline & 675 & 139 & 5.54 & 6.10 & 21 & 200,919 & 223 \\
\hline \multirow{3}{*}{$\begin{array}{c}1980 \\
(4 S W-280 R C)\end{array}$} & 41 & 744 & 6.68 & 8.18 & 144 & 159,623 & 810 \\
\hline & 358 & 427 & 5.65 & 4.83 & 10 & 237,858 & 192 \\
\hline & 675 & 110 & 4.09 & 4.18 & - & 246,504 & 135 \\
\hline \multirow{3}{*}{$\begin{array}{c}1981 \\
(4 \mathrm{~W}-190 \mathrm{RC})\end{array}$} & 52 & 731 & 7.46 & 4.85 & - & 185,726 & 192 \\
\hline & 339 & 444 & 6.06 & 3.98 & - & 189,219 & 168 \\
\hline & 510 & 273 & 5.94 & 4.33 & - & 193,268 & 105 \\
\hline \multicolumn{3}{|c|}{ 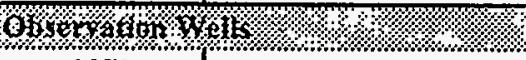 } & $2.1 \%$ & (1. & & 1 1. & . \\
\hline \multirow{3}{*}{$\begin{array}{c}1972 \\
(4 \mathrm{~N}-200 \mathrm{~W})\end{array}$} & 32 & 736 & 10.50 & 7.67 & 35 & 133 & 29 \\
\hline & 563 & 205 & 11.23 & 10.71 & 131 & 318 & - \\
\hline & 1050 & -282 & 11.58 & 11.23 & 955 & 1,742 & 35 \\
\hline \multirow{3}{*}{$\begin{array}{c}1975 \\
(4 \mathrm{NW}-400 \mathrm{~W})\end{array}$} & 25 & 745 & 10.18 & 9.84 & 192 & 492 & 32 \\
\hline & 493 & 277 & 9.73 & 9.82 & 189 & 457 & 20 \\
\hline & 887 & -117 & 12.57 & 12.33 & 9,031 & 89,927 & 924 \\
\hline \multirow{3}{*}{$\begin{array}{c}1977 \\
(4 S-200 W)\end{array}$} & 29 & 770 & 8.69 & 8.45 & 12 & 212 & 23 \\
\hline & 256 & 543 & 11.28 & 11.06 & 98 & 333 & 12 \\
\hline & 483 & 316 & 11.00 & 11.15 & 112 & 1,382 & - \\
\hline \multirow{3}{*}{$\begin{array}{c}1978 \\
(4 S E-125 W)\end{array}$} & 22 & 765 & 8.89 & 7.57 & 24 & 258 & 14 \\
\hline & 571 & 216 & 11.44 & 11.48 & 199 & 709 & 10 \\
\hline & 1120 & -333 & 12.29 & 12.06 & 1,422 & 20,139 & 7 \\
\hline \multirow{3}{*}{$\begin{array}{c}1982 \\
(4 \mathrm{~W}-200 \mathrm{~W})\end{array}$} & 36 & 747 & 11.38 & 11.65 & 192 & 432 & 7 \\
\hline & 581 & 202 & 12.11 & 11.90 & 571 & 1,262 & 25 \\
\hline & 1094 & -311 & 11.86 & 11.78 & 915 & 1,646 & 153 \\
\hline
\end{tabular}


Table 4.1. CSL analytical data summary for $\mathrm{pH}$, alkalinity, TDS, and TSS (continued)

\begin{tabular}{|c|c|c|c|c|c|c|c|}
\hline \multirow[b]{2}{*}{ Station } & \multicolumn{2}{|c|}{ Sample } & \multicolumn{2}{|c|}{$\mathrm{pH}$} & \multirow{2}{*}{$\begin{array}{c}\text { Alkalinity } \\
(\mathrm{mg} \mathrm{CaCO} / \mathrm{L})\end{array}$} & \multirow{2}{*}{$\begin{array}{c}\text { TDS } \\
(\mathrm{mg} / \mathrm{L})\end{array}$} & \multirow{2}{*}{$\begin{array}{c}\text { TSS } \\
(\mathrm{mg} / \mathrm{L})\end{array}$} \\
\hline & Depth, ft & Elev., ft & field & laboratory & & & \\
\hline \multicolumn{3}{|c|}{ 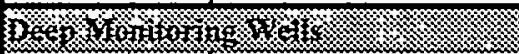 } & & & & & \\
\hline \multirow{3}{*}{$\begin{array}{c}2373 \\
\text { (DM1-RM) }\end{array}$} & 123 & 642 & 8.49 & 7.34 & 24 & 144,980 & 128 \\
\hline & 624 & 141 & 7.82 & 6.35 & 38 & 156,099 & 165 \\
\hline & 1124 & -359 & 11.10 & 8.41 & 31,378 & 146,150 & 277,140 \\
\hline \multirow{3}{*}{$\begin{array}{c}2374 \\
(\mathrm{DM} 2-\mathrm{RM})\end{array}$} & 262 & 496 & 7.59 & 7.60 & 65 & 104,931 & 46 \\
\hline & 756 & 2 & 6.53 & 5.28 & 28 & 266,015 & 108 \\
\hline & 1245 & -487 & 6.16 & 5.19 & 21 & 277,376 & 125 \\
\hline \multirow{3}{*}{$\begin{array}{c}2375 \\
\text { (DM3A-PV) }\end{array}$} & 52 & 717 & 8.45 & 6.24 & 14 & 23,014 & 35 \\
\hline & 469 & 300 & 6.86 & 5.94 & 21 & 24,132 & 89 \\
\hline & 880 & -111 & 6.51 & 5.60 & 21 & 59,120 & 203 \\
\hline \multirow{3}{*}{$\begin{array}{c}2952 \\
\text { (DM1-RT) }\end{array}$} & 200 & 566 & 11.26 & 10.74 & 121 & 15,402 & 24 \\
\hline & 449 & 317 & 6.06 & 5.07 & 15 & 221,933 & 147 \\
\hline & 696 & 70 & 5.55 & 4.20 & - & 237,648 & 193 \\
\hline \multirow{3}{*}{$\begin{array}{c}2953 \\
\text { (DM3-RT) }\end{array}$} & 65 & 689 & 7.67 & 6.64 & 31 & 145,686 & 138 \\
\hline & 328 & 426 & 6.35 & 6.05 & 30 & 153,229 & 96 \\
\hline & 580 & 174 & 5.53 & 5.22 & 16 & 156,265 & 426 \\
\hline \multirow{3}{*}{$\begin{array}{c}2954 \\
\text { (DM1-PV) }\end{array}$} & 60 & 705 & 9.26 & 8.90 & 612 & 211,321 & 79 \\
\hline & 569 & 196 & 9.05 & 9.03 & 461 & 217,745 & 136 \\
\hline & 1038 & -273 & 8.12 & 8.19 & 4,959 & 200,500 & 82,360 \\
\hline \multirow{3}{*}{$\begin{array}{c}2955 \\
\text { (DM2-PV) }\end{array}$} & 32 & 727 & 9.00 & 8.59 & 332 & 254,516 & 172 \\
\hline & 535 & 224 & 7.79 & 4.55 & - & 270,250 & 379 \\
\hline & 1038 & -279 & 7.40 & 5.13 & 14 & 268,125 & 179 \\
\hline
\end{tabular}

Note: "-" indicates the analyte was not detected. 
Table 4.2. Close Support Laboratory analytical data summary for cations and anions in New Hydrofracture Facility wells.

\begin{tabular}{|c|c|c|c|c|c|c|c|c|c|c|c|c|c|c|c|c|}
\hline \multirow[b]{2}{*}{ Station } & \multicolumn{2}{|c|}{ Sample } & \multicolumn{6}{|c|}{ Cations (mg/L) } & \multicolumn{8}{|c|}{ Anions (mg/L) } \\
\hline & Depth, $\mathbf{n}$ & Elev., $\mathrm{n}$ & Ammonium & Calcium & Lithium & Magneslum & Potasslum & Sodlum & Chloride & Sulfate & $\mathrm{HCO}_{3}$ & $\mathrm{CO}_{3}$ & Bromlde & Fluoride & Nitrate & Phosphate \\
\hline \multicolumn{3}{|c|}{$f(1)<\alpha$} & & & x & & & (1) & & & & 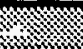 & $\$$ & & 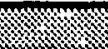 & \\
\hline \multirow{3}{*}{$\begin{array}{c}1969 \\
(4 \mathrm{E}-200 \mathrm{RC})\end{array}$} & 96 & 693 & - & 14000 & - & 2170 & 164 & 43000 & 91000 & - & - & - & 722 & - & - & - \\
\hline & 339 & 450 & -. & 15200 & - & 3480 & 131 & 46700 & 102000 & - & - & - & 866 & - & - & - \\
\hline & 625 & 164 & - & 18700 & - & 3910 & 126 & 48800 & 114000 & - & - & - & 959 & - & - & - \\
\hline \multirow{3}{*}{$\begin{array}{c}1971 \\
(4 \mathrm{~N}-200 \mathrm{RC})\end{array}$} & 62 & 706 & - & 13500 & - & 2570 & 90 & 36500 & 91400 & -. & - & $\ldots$ & 714 & - & $\ldots$ & - \\
\hline & 261 & 507 & - & 15000 & - & 3100 & 96 & 40600 & 99600 & - & - & - & 776 & - & - & - \\
\hline & 387 & 381 & - & 15000 & - & 3080 & 93 & 41300 & 99600 & $\ldots$ & $\ldots$ & - & 782 & - & - & - \\
\hline \multirow{3}{*}{$\begin{array}{c}1973 \\
(4 \mathrm{NE}-280 \mathrm{RC})\end{array}$} & 76 & 689 & -. & 5280 & - & 1410 & 56 & 21700 & 48000 & - & -. & -. & 134 & $\ldots$ & - & -. \\
\hline & 317 & 448 & -- & 12400 & .- & 2930 & 207 & 38600 & 85800 & .. & - & - & 680 & - & -. & - \\
\hline & 557 & 208 & - & 14300 & - & 3300 & 96 & 42100 & 94900 & - & - & - & 2170 & - & .. & - \\
\hline \multirow{3}{*}{$\begin{array}{c}1974 \\
(4 N W-340 R C)\end{array}$} & 45 & 724 &.- & 13200 & $\cdots$ & 3080 & 102 & 43000 & 92300 & - & .. & $\ldots$ & 697 & $\ldots$ & - & $\ldots$ \\
\hline & 300 & 469 & -- & 13200 & - & 3130 & 98 & 42800 & 89800 & -. & - & - & 696 & - & - & - \\
\hline & 555 & 214 & - & 14900 & -. & 3450 & 99 & 45200 & 99400 & - & .. & - & 791 & .. & $\ldots$ & - \\
\hline \multirow{3}{*}{$\begin{array}{c}1976 \\
\text { (4S-200RC) }\end{array}$} & 105 & 696 & -- & 4110 & - & 827 & 36 & 11100 & 27100 & - & - & 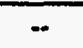 & 208 & 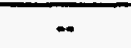 & - & - \\
\hline & 390 & 411 & -- & 23300 & .. & 4430 & 134 & 49800 & 134000 & -. & - &. & 1230 & -. & - & -. \\
\hline & 674 & 127 & - & 25200 & $\ldots$ & 4710 & 119 & 53500 & 138000 & $=$ & - & 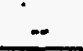 & 1260 & $\ldots$ & .. & - \\
\hline \multirow{3}{*}{$\begin{array}{c}1979 \\
(4 \mathrm{SE}-280 \mathrm{RC})\end{array}$} & 122 & 692 & - & 4670 & - & 78 & 89 & 16700 & 34000 & $\ldots$ & $\cdots$ & - & 230 & $\cdots$ & - & - \\
\hline & 398 & 416 & -- & 13400 & -. & 2190 & 144 & 39000 & 87800 & -- & .. & - & 668 & - & -. & - \\
\hline & 675 & 139 & - & 21800 & - & 4320 & 138 & 51100 & 125000 & - & 26 & 0 & 1060 & - & $=$ & - \\
\hline \multirow{3}{*}{$\begin{array}{c}1980 \\
\text { (4SW-280RC) }\end{array}$} & 41 & 744 &.. & 19500 & .. & 1520 & 123 & 41200 & 101000 &.- & 176 & 0 & 901 & $\cdots$ & -. & - \\
\hline & 358 & 427 & .. & 28500 & .. & 5580 & 140 & 57800 & 155000 & .- & 12 & 0 & 1390 & -. & .. & -- \\
\hline & 675 & 110 & $-\cdot$ & 28700 & $=$ & 5840 & 137 & 56300 & 151000 & .. & - &.- & 1450 & $\cdots$ & -. & -. \\
\hline \multirow{3}{*}{$\begin{array}{c}1981 \\
(4 W-190 \mathrm{RC})\end{array}$} & 52 & 731 & -- & 20300 & 20 & 3820 & 145 & 48100 & 117000 & 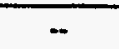 & $\overline{-}$ & -- & 939 & $\ldots$ & - & $\cdots$ \\
\hline & 339 & 444 & - & 21200 & 20 & 4190 & 136 & 49300 & 116000 & -- & .. & .. & 996 & $\ldots$ & -- & - \\
\hline & 510 & 273 & -- & 21400 & 20 & 4220 & 130 & 49200 & 122000 & .. & -. & $\ldots$ & 983 & - & - & $\ldots$ \\
\hline \multicolumn{3}{|c|}{ 30\% \% } & $\%$ & \% & 原. & 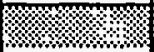 & \% & \% & $1 \%$ & \% & \% & $\%$ & . & \% & \% & $1 \%$ \\
\hline \multirow{3}{*}{$\begin{array}{c}1972 \\
(4 \mathrm{~N}-200 \mathrm{~W})\end{array}$} & 32 & 736 & 4.76 & 15.5 & $\cdots$ & 1.62 & 2.68 & 10.9 & 6.33 & 33.8 & 10 & 11 & - & 1.86 & - & $\ldots$ \\
\hline & 563 & 205 & 19.4 & 53.5 & - & - & 3.46 & 12 & 8.96 & 51.3 & 8 & 48 & - & 0.62 & -. & - \\
\hline & 1050 & -282 & 199 & 369 & .. & 0.21 & 20.5 & 17.3 & 5.95 & 155 & 34 & 496 & - & 3.04 & .. & -- \\
\hline \multirow{3}{*}{$\begin{array}{c}1975 \\
(4 N W-400 W)\end{array}$} & 25 & 745 & 4.7 & 2.4 & 0.2 & 0.3 & 6.5 & 93.3 & 15.4 & -. & 100 & 63 & - & 0.5 & $\cdots$ & 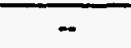 \\
\hline & 493 & 277 & 4.6 & 2.5 & 0.2 & 0.7 & 6.5 & 95.8 & 24.9 & 0.6 & 153 & 37 & - & 0.5 & .. & -- \\
\hline & 887 & -117 & 54 & 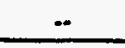 & - & - & 854 & 37000 & 35100 & 811 & 22 & 3966 & 119 & - & 12600 & 203 \\
\hline \multirow{3}{*}{$\begin{array}{c}1977 \\
(4 S-200 W)\end{array}$} & 29 & 770 & 1.7 & 11.8 & .. & 0.6 & 3.3 & 10.3 & 6.6 & 29.5 & 14 & 0 & - & 0.9 & .. & -. \\
\hline & 256 & 543 & 2.7 & 51 & -. & -. & 3.4 & 11.1 & 15.1 & 45.1 & 3 & 23 & - & 1.9 & .. & - \\
\hline & 483 & 316 & 3.5 & 50.3 & - & -. & 3.6 & 10.6 & 6.6 & 46.3 & 11 & 42 & $\ldots$ & 2 & - & -. \\
\hline
\end{tabular}


Table 4.2. CSL analytical data summary for cations and anions in NHF wells (continued)

\begin{tabular}{|c|c|c|c|c|c|c|c|c|c|c|c|c|c|c|c|c|}
\hline \multirow[b]{2}{*}{ Station } & \multicolumn{2}{|c|}{ Sample } & \multicolumn{6}{|c|}{ Cations (mg/L) } & \multicolumn{8}{|c|}{ Anlons ( $\mathrm{mg} / \mathrm{L})$} \\
\hline & Depth, ft & Elev., $\mathrm{ft}$ & Ammonlum & Calcium & Lithium & Magnesium & Potassium & Sodium & Chloride & Sulfate & $\mathrm{HCO}_{3}$ & $\mathrm{CO}_{3}$ & Bromide & Fluoride & Nitrate & Phosphate \\
\hline \multicolumn{3}{|c|}{ 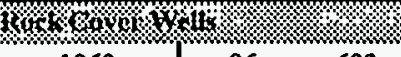 } & & & & & - & & & 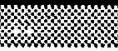 & & & & & & \\
\hline \multirow{3}{*}{$\begin{array}{c}1969 \\
\text { (4E-200RC) }\end{array}$} & 96 & 693 & - & 14000 & - & 2170 & 164 & 43000 & 91000 & - & - & - & 722 & - & - & - \\
\hline & 339 & 450 & $\cdots$ & 15200 & - & 3480 & 131 & 46700 & 102000 & - & - & - & 866 & - & - & - \\
\hline & 625 & 164 & - & 18700 & - & 3910 & 126 & 48800 & 114000 & - & - & - & 959 & - & - & - \\
\hline \multirow{3}{*}{$\begin{array}{c}1971 \\
(4 \mathrm{~N}-200 \mathrm{RC})\end{array}$} & 62 & 706 & - & 13500 & - & 2570 & 90 & 36500 & 91400 & - & - & - & 714 & - & - & - \\
\hline & 261 & 507 & - & 15000 & -- & 3100 & 96 & 40600 & 99600 & - & - & - & 776 & - & -. & - \\
\hline & 387 & 381 & - & 15000 & - & 3080 & 93 & 41300 & 99600 & - & - & - & 782 & $\ldots$ & - & - \\
\hline \multirow{3}{*}{$\begin{array}{c}1973 \\
(4 \mathrm{NE}-280 \mathrm{RC})\end{array}$} & 76 & 689 & - & 5280 & - & 1410 & 56 & 21700 & 48000 & - & - & - & 134 & - & - & - \\
\hline & 317 & 448 & $\cdots$ & 12400 & -- & 2930 & 207 & 38600 & 85800 & - & - & - & 680 & - & .. & - \\
\hline & 557 & 208 & - & 14300 & .. & 3300 & 96 & 42100 & 94900 & - & - & - & 2170 & - & $\ldots$ & $\ldots$ \\
\hline \multirow{3}{*}{$\begin{array}{c}1974 \\
(4 N W-340 R C)\end{array}$} & 45 & 724 & - & 13200 & - & 3080 & 102 & 43000 & 92300 & .. & - & -. & 697 & $\ldots$ & - & - \\
\hline & 300 & 469 & -. & 13200 & -- & 3130 & 98 & 42800 & 89800 & - & - & - & 696 & - & -. & - \\
\hline & 555 & 214 & - & 14900 & - & 3450 & 99 & 45200 & 99400 & .. & .- & $\ldots$ & 791 & - & .. & $\ldots$ \\
\hline \multirow{3}{*}{$\begin{array}{c}1976 \\
(4 S-200 \mathrm{RC})\end{array}$} & 105 & 696 & - & 4110 & - & 827 & 36 & 11100 & 27100 & .. & .- & .. & 208 & - & - & - \\
\hline & 390 & 411 & -. & 23300 & .. & 4430 & 134 & 49800 & 134000 & - & - & - & 1230 & - & - & -. \\
\hline & 674 & 127 & - & 25200 & -- & 4710 & 119 & 53500 & 138000 & - & - & - & 1260 & - & - & .. \\
\hline \multirow{3}{*}{$\begin{array}{c}1979 \\
\text { (4SE-280RC) }\end{array}$} & 122 & 692 & - & 4670 & -. & 78 & 89 & 16700 & 34000 &.- & - & -. & 230 & - & .. & - \\
\hline & 398 & 416 & -- & 13400 & - & 2190 & 144 & 39000 & 87800 & .. & -. & .. & 668 & -. & -- & .. \\
\hline & 675 & 139 & - & 21800 & - & 4320 & 138 & 51100 & 125000 & -. & 26 & 0 & 1060 & - & - & $\ldots$ \\
\hline \multirow{3}{*}{$\begin{array}{c}1980 \\
(4 S W-280 R C)\end{array}$} & 41 & 744 & - & 19500 & $\ldots$ & 1520 & 123 & 41200 & 101000 & -- & 176 & 0 & 901 & .. & -- & .. \\
\hline & 358 & 427 & -- & 28500 & - & 5580 & 140 & 57800 & 155000 & .- & 12 & 0 & 1390 & -- & -. & $\ldots$ \\
\hline & 675 & 110 & - & 28700 & .. & 5840 & 137 & 56300 & 151000 & .. & -. & - & 1450 & - & - & .. \\
\hline \multirow{3}{*}{$\begin{array}{c}1981 \\
(4 W-190 R C)\end{array}$} & 52 & 731 & - & 20300 & 20 & 3820 & 145 & 48100 & 117000 & - & - & - & 939 & - & - & .. \\
\hline & 339 & 444 & - & 21200 & 20 & 4190 & 136 & 49300 & 116000 & -. & -- & -- & 996 & -. & .. & -. \\
\hline & 510 & 273 & -. & 21400 & 20 & 4220 & 130 & 49200 & 122000 & -. & -. & - & 983 & - & -- & - \\
\hline \multicolumn{3}{|c|}{ 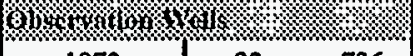 } & $8 \%$ & & 8 & . & & & $4 x$ & 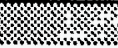 & & & & & & \\
\hline \multirow{3}{*}{$\begin{array}{c}1972 \\
(4 N-200 W)\end{array}$} & 32 & 736 & 4.76 & 15.5 & - & 1.62 & 2.68 & 10.9 & 6.33 & 33.8 & 10 & 11 & -. & 1.86 & -- & -. \\
\hline & 563 & 205 & 19.4 & 53.5 & -- & .. & 3.46 & 12 & 8.96 & .51 .3 & 8 & 48 & -. & 0.62 & - & - \\
\hline & 1050 & -282 & 199 & 369 & - & 0.21 & 20.5 & 17.3 & 5.95 & 155 & 34 & 496 & - & 3.04 & - & $\ldots$ \\
\hline \multirow{3}{*}{$\begin{array}{c}1975 \\
(4 N W-400 W)\end{array}$} & 25 & 745 & 4.7 & 2.4 & 0.2 & 0.3 & 6.5 & 93.3 & 15.4 & - & 100 & 63 & - & 0.5 & - & -- \\
\hline & 493 & 277 & 4.6 & 2.5 & 0.2 & 0.7 & 6.5 & 95.8 & 24.9 & 0.6 & 153 & 37 & - & 0.5 & -. & - \\
\hline & 887 & -117 & 54 & - & - & - & 854 & 37000 & 35100 & 811 & 22 & 3966 & 119 & - & 12600 & 203 \\
\hline \multirow{3}{*}{$\begin{array}{c}1977 \\
(4 S-200 W)\end{array}$} & 29 & 770 & 1.7 & 11.8 &.. & 0.6 & 3.3 & 10.3 & 6.6 & 29.5 & 14 & 0 & - & 0.9 & - & -. \\
\hline & 256 & 543 & 2.7 & 51 & -. & - & 3.4 & 11.1 & 15.1 & 45.1 & 3 & 23 & - & 1.9 & - & - \\
\hline & 483 & 316 & 3.5 & 50.3 & - & - & 3.6 & 10.6 & 6.6 & 46.3 & 11 & 42 & - & 2 & - & .- \\
\hline
\end{tabular}


Table 4.3. Close Support Laboratory analytical data summary for radionuclides in New Hydrofracture Facility wells

\begin{tabular}{|c|c|c|c|c|c|c|c|c|c|c|}
\hline \multirow[b]{2}{*}{ Station } & \multicolumn{2}{|c|}{ Sample } & \multirow{2}{*}{$\begin{array}{l}\text { Gross } \alpha \\
(\mathrm{nCi} / L)\end{array}$} & \multirow{2}{*}{$\begin{array}{l}\text { Gross } \beta \\
(\mathrm{pCi} / \mathrm{L})\end{array}$} & \multirow{2}{*}{$\begin{array}{c}\mathrm{C}-14 \\
(\mathrm{pCi} / \mathrm{L})\end{array}$} & \multirow{2}{*}{$\begin{array}{l}\mathrm{Cs}-137 \\
(\mathrm{pCi} / \mathrm{L})\end{array}$} & \multirow{2}{*}{$\begin{array}{l}\mathrm{Co-60} \\
(\mathrm{pCi} / \mathrm{L})\end{array}$} & \multirow{2}{*}{$\begin{array}{l}\text { Total } \gamma \\
(\mathrm{pCi} / \mathrm{L})\end{array}$} & \multirow{2}{*}{$\begin{array}{c}\mathrm{Sr}-90 \\
(\mathrm{pCi} / \mathrm{L})\end{array}$} & \multirow{2}{*}{$\begin{array}{c}\mathrm{H}-3 \\
(\mathrm{pC} / \mathrm{L})\end{array}$} \\
\hline & Depth, ft & Elev., ft & & & & & & & & \\
\hline \multicolumn{3}{|c|}{ 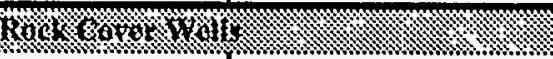 } & & \% & wa & & k & $\ldots$ & & \\
\hline \multirow{3}{*}{$\begin{array}{c}1969 \\
(4 \mathrm{E}-200 \mathrm{RC})\end{array}$} & 96 & 693 & - & - & - & & & - & & - \\
\hline & 339 & 450 & - & - & - & 293 & & 293 & & - \\
\hline & 625 & 164 & - & - & - & 29.3 & & 29.3 & & - \\
\hline \multirow{3}{*}{$\begin{array}{c}1971 \\
(4 \mathrm{~N}-200 \mathrm{RC})\end{array}$} & 62 & 706 & - & - & - & & & - & & 200.9 \\
\hline & 261 & 507 & - & - & - & & & - & & 4561.3 \\
\hline & 387 & 381 & - & - & - & & & - & & 1156.8 \\
\hline \multirow{3}{*}{$\begin{array}{c}1973 \\
(4 \mathrm{NE}-280 \mathrm{RC})\end{array}$} & 76 & 689 & - & - & - & & & - & & - \\
\hline & 317 & 448 & - & - & - & 107 & & 107 & & - \\
\hline & 557 & 208 & $\cdots$ & - & - & 234 & & 234 & & - \\
\hline \multirow{3}{*}{$\begin{array}{c}1974 \\
(4 \mathrm{NW}-340 \mathrm{RC})\end{array}$} & 45 & 724 & - & - & - & & & - & & - \\
\hline & 300 & 469 & - & - & - & & & - & & - \\
\hline & 555 & 214 & - & - & - & & & - & & - \\
\hline \multirow{3}{*}{$\begin{array}{c}1976 \\
(4 S-200 R C)\end{array}$} & 105 & 696 & - & - & -- & 32.4 & & 32.4 & & - \\
\hline & 390 & 411 & - & - & - & 36.9 & & 36.9 & & - \\
\hline & 674 & 127 & - & $=$ & - & 37.1 & & 37.1 & & - \\
\hline \multirow{3}{*}{$\begin{array}{c}1979 \\
(4 \mathrm{SE}-280 \mathrm{RC})\end{array}$} & 122 & 692 & - & 1589.2 & - & & & -- & & 161.3 \\
\hline & 398 & 416 & - & - & - & & & $\cdots$ & & - \\
\hline & 675 & 139 & $\cdots$ & - & - & & & - & & - \\
\hline \multirow{3}{*}{$\begin{array}{c}1980 \\
(4 S W-280 R C)\end{array}$} & 41 & 744 & -- & - & $\cdots$ & & & $\overline{-}$ & & 211.7 \\
\hline & 358 & 427 & $\cdots$ & $\cdots$ & - & & & - & & 535.1 \\
\hline & 675 & 110 & - & - & - & & & - & & 153.2 \\
\hline \multirow{3}{*}{$\begin{array}{c}1981 \\
(4 \mathrm{~W}-190 \mathrm{RC})\end{array}$} & 52 & 731 & - & 1837.3 & 227 & & & - & & - \\
\hline & 339 & 444 & -- & 4484.5 & - & 48.8 & & 48.8 & & - \\
\hline & 510 & 273 & - & 1819.9 & - & 45.9 & & 45.9 & & - \\
\hline \multicolumn{3}{|c|}{ 6) } & & & & $4 \%$ & & \% & & \\
\hline \multirow{3}{*}{$\begin{array}{c}1972 \\
(4 \mathrm{~N}-200 \mathrm{~W})\end{array}$} & 32 & 736 & - & 9954.9 & 5109 & 483 & & 483 & 5808.6 & - \\
\hline & 563 & 205 & - & 3489.1 & 1945 & 403 & & 403 & & - \\
\hline & 1050 & -282 & - & 997.1 & 1116.2 & 841 & & 841 & & - \\
\hline \multirow{3}{*}{$\begin{array}{c}1975 \\
(4 \mathrm{NW}-400 \mathrm{~W})\end{array}$} & 25 & 745 & 6.2 & 458.5 & - & 212 & & 212 & & $\ldots$ \\
\hline & 493 & 277 & - & 743.1 & - & 216 & & 216 & & $-\cdots$ \\
\hline & 887 & -117 & - & $11744758^{\circ}$ & 4546.8 & 14100000 & 219000 & 14300000 & 35059.6 & 1662216.2 \\
\hline
\end{tabular}




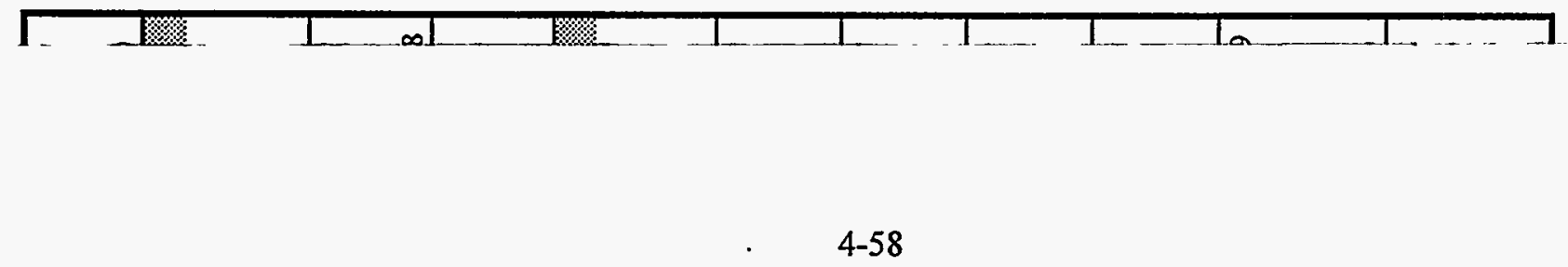

Table 4.4. Historical sample analyses for $\mathrm{pH}$, alkalinity, conductivity, TDS, and temperature (continued)

\begin{tabular}{|c|c|c|c|c|c|c|c|c|c|}
\hline \multirow[b]{2}{*}{ Station } & \multicolumn{3}{|c|}{ Sample } & \multicolumn{2}{|c|}{$\mathrm{pH}$} & \multirow{2}{*}{$\begin{array}{c}\text { Alkalinity } \\
\left(\mathrm{mg} \mathrm{HCO}_{3} / \mathrm{L}\right)\end{array}$} & \multirow{2}{*}{$\begin{array}{c}\text { Conductivity } \\
(\mu \mathrm{S} / \mathrm{cm})\end{array}$} & \multirow{2}{*}{$\begin{array}{c}\text { TDS } \\
(\mathrm{mg} / \mathrm{L})\end{array}$} & \multirow{2}{*}{$\begin{array}{l}\text { Temp } \\
\left({ }^{\circ} \mathrm{C}\right)\end{array}$} \\
\hline & Date & Depth, & & Field & Laboratory & & & & \\
\hline \multicolumn{4}{|c|}{ 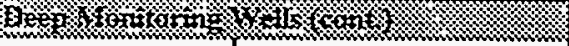 } & & & 8 & & & \\
\hline 2374 & Sep-84 & 640 & $\mathrm{~F}$ & 6.1 & & 72 & 22900 & 13415 & 18.4 \\
\hline \multirow[t]{10}{*}{ (DM2-RM) } & & 840 & $\mathbf{F}$ & 5.6 & & 15 & 5400 & 74182 & 19.4 \\
\hline & & 960 & F & 5.7 & & 27 & 83200 & 71988 & 19.4 \\
\hline & & 1040 & F & 5.8 & & 27 & 77500 & 51669 & 17.7 \\
\hline & & 1400 & F & 5.2 & & - & 189700 & 199202 & 20.2 \\
\hline & Jan-85 & 640 & $\mathrm{~F}$ & 5.4 & & 7 & 42200 & 92450 & 10.5 \\
\hline & & 840 & $\mathbf{F}$ & 5.2 & & - & 68400 & 139170 & 11.5 \\
\hline & & 960 & F & 5.2 & & - & 49700 & 130340 & 10.3 \\
\hline & & 1040 & $\mathrm{~F}$ & 5.2 & & - & 47800 & 120640 & 11.3 \\
\hline & & 1400 & $\mathrm{~F}$ & 4.6 & & - & 77400 & 295830 & 11.7 \\
\hline & Jan-86 & 1250 & $\mathrm{U}$ & 10.3 & & 366 & 75700 & 141500 & 10.4 \\
\hline \multirow{9}{*}{$\begin{array}{c}2375 \\
\text { (DM3A-PV) }\end{array}$} & Sep-84 & 610 & $\mathbf{F}$ & 8.9 & & 113 & 865 & 341 & 16.9 \\
\hline & & 850 & F & 8.1 & & 123 & 979 & 414 & 18.6 \\
\hline & & 940 & F & 8.3 & & 115 & 982 & 392 & 16.5 \\
\hline & & 1100 & $\mathbf{F}$ & 6.8 & & 90 & 3810 & 5919 & 18.3 \\
\hline & $\operatorname{Jan}-85$ & 610 & $\mathbf{F}$ & 8.7 & & 114 & 471 & 620 & 11.2 \\
\hline & & 850 & $\mathbf{F}$ & 8.5 & & 135 & 619 & 804 & 12.6 \\
\hline & & 940 & $\mathbf{F}$ & 8.3 & & 136 & 1860 & 816 & 12.8 \\
\hline & & 1100 & $\mathrm{~F}$ & 7.8 & & 128 & 18210 & 29695 & 11.3 \\
\hline & Jan-86 & 875 & $\mathrm{U}$ & 6.9 & & 60 & 63000 & 39347 & 12.8 \\
\hline 2952 (DM1-RT) & Jan-86 & 700 & $\mathrm{U}$ & 6.8 & & 3 & 160200 & 145740 & 12.4 \\
\hline 2953 (DM3-RT) & Jan-86 & 550 & $\mathrm{U}$ & 4.6 & & - & 61000 & 143340 & 9 \\
\hline 2954 (DM1-PV) & Jan-86 & 1050 & $\mathrm{U}$ & 4.4 & & - & - & 237640 & 10 \\
\hline 2955 (DM2-PV) & Jan-86 & 1050 & $\mathrm{U}$ & 4.3 & & - & - & 240230 & 13.9 \\
\hline
\end{tabular}

Compiled from: Haase, Switek, and Stow 1987 and Switek, Haase, and Stow 1987.

Note: "-" indicates analyte was not detected. A blank indicates no analysis was performed.

$\alpha$ - alpha and $\beta$ - beta; $U$ - unfiltered and F - filtered 
Table 4.5. Historical sample analyses for cations and anions in New Hydrofracture Facility wells

\begin{tabular}{|c|c|c|c|c|c|c|c|c|c|c|c|c|c|c|c|c|c|c|c|}
\hline \multirow[b]{2}{*}{ Station } & \multicolumn{3}{|c|}{ Sample } & \multicolumn{9}{|c|}{ Cations (mg/L) } & \multicolumn{7}{|c|}{ Anlons (mg/L) } \\
\hline & Date & Depth & & $\mathbf{C a}$ & $\mathrm{Na}$ & $\overline{\mathbf{M g}}$ & $\bar{K}$ & $\mathrm{Mn}$ & $\overline{F e}$ & $\mathbf{L I}$ & $\mathrm{Ba}$ & $\mathbf{S r}$ & CI & so, & $\mathrm{Br}$ & $\mathrm{PO}_{4}$ & $\mathrm{NO}_{3}$ & $F$ & $I$ \\
\hline \multirow{6}{*}{$\begin{array}{c}\text { Row } \\
1969 \\
(4 \mathrm{E}-200 \mathrm{RC})\end{array}$} & 4 & & & & $\ldots$ & s. & 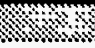 & & $m$ & $x$ & \% & & w & & wo & 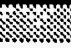 & & & \\
\hline & Oet-83 & & F & 13400 & 26600 & 3040 & 11400 & 17.7 & 23 & 40.6 & 498 & 1620 & 101000 & - & 933 & & - & & \\
\hline & $\operatorname{Jan}-85$ & 640 & F & 12200 & 44500 & 2880 & 160 & 13.7 & 5.12 & 58.8 & 599 & 1540 & 120000 & - & 830 & - & 5 & .46 & - \\
\hline & May-86 & 640 & $\mathbf{U}$ & 19000 & 48000 & 3300 & & 30 & 39 & - & 660 & 2000 & 120000 & - & 880 & & 32 & .33 & 18 \\
\hline & Dec-86 & 635 & $\mathbf{F}$ & 17000 & 42000 & 3100 & 170 & 30 & 32 & - & 610 & 1800 & 122000 & - & 1300 & - & 2 & 400 & - \\
\hline & Dec-86 & 635 & $\mathrm{U}$ & 19000 & 46000 & 3400 & 180 & 33 & 73 & - & 660 & 2000 & & & & & & & \\
\hline \multirow{4}{*}{$\begin{array}{c}1971 \\
(4 \mathrm{~N}-200 \mathrm{RC})\end{array}$} & Oct-83 & 570 & $\mathbf{F}$ & 717 & 2180 & 168 & 954 & 1.4 & - & 4 & 18.9 & 79 & 3200 & - & 45 & & - & & \\
\hline & May-86 & 400 & $\mathrm{U}$ & 16000 & 44000 & 2900 & & 20 & 25 & -. & 500 & 1600 & $97000^{\circ}$ & - & 770 & & 28 & .03 & 15 \\
\hline & Dec-86 & 365 & $\mathbf{F}$ & 15000 & 41000 & 2800 & 140 & 20 & 42 & - & 480 & 1600 & 106000 & - & 900 & - & 3.01 & 280 & - \\
\hline & Dec-86 & 365 & $\mathrm{U}$ & 14000 & 40000 & 2800 & 150 & 20 & 70 & $\ldots$ & 470 & 1500 & & & & & & & \\
\hline \multirow{5}{*}{$\begin{array}{c}1973 \\
(4 \mathrm{NE}-280 \mathrm{RC})\end{array}$} & Oct-83 & 570 & $\mathrm{~F}$ & 15500 & 27700 & 3120 & 17300 & 10.9 & - & $\$ 3.2$ & 478 & 1880 & 117000 & - & 1101 & & - & & \\
\hline & Jan-85 & 580 & $\mathbf{F}$ & 12200 & 41600 & 2770 & 130 & 25.5 & 13.6 & 25.7 & 463 & 1530 & 100000 & - & 800 & - & 4 & .29 & - \\
\hline & May-86 & 580 & $\mathbf{U}$ & 16000 & 44000 & 3000 & & 33 & 47 & -- & 530 & 1600 & 95000 & - & 790 & & 34 & .3 & 16 \\
\hline & Dec-86 & 570 & $\mathbf{F}$ & 12000 & 33000 & 2400 & 160 & 29 & 49 & - & 450 & 1400 & 95700 & - & 950 & - & 2.6 & 190 & - \\
\hline & Dec-86 & 570 & U & 12000 & 34000 & 2500 & 160 & 30 & 110 & - & 450 & 1400 & & & & & & & \\
\hline \multirow{4}{*}{$\begin{array}{c}1974 \\
(4 N W-340 R C)\end{array}$} & Oct-83 & 570 & $F$ & 2820 & 8890 & 1930 & 1430 & - & - & 13.4 & 119 & 297 & 23400 & 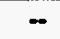 & 190 & & - & & \\
\hline & May-86 & 580 & $\mathbf{U}$ & 17000 & 46000 & 3200 & & 19 & 69 & - & 550 & 1700 & 100000 & - & 770 & & 54 & .44 & 11 \\
\hline & Dec-86 & 570 & $\mathbf{F}$ & 15000 & 43000 & 3000 & 140 & 22 & 77 & - & 530 & 1600 & 10600 & - & 450 & .. & .71 & 140 & - \\
\hline & Dec-86 & 570 & $\mathbf{U}$ & 15000 & 42000 & 2900 & 140 & 22 & 99 & - & 520 & 1600 & & & & & & & \\
\hline \multirow{5}{*}{$\begin{array}{c}1976 \\
(4 \mathrm{~S}-200 \mathrm{RC})\end{array}$} & Oct-83 & 690 & $F$ & 4810 & 11400 & 736 & 5190 & 1.6 & - & 18.7 & 162 & 551 & 33700 & 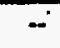 & 238 & & - & & \\
\hline & Jan1-85 & 590 & $\mathbf{F}$ & 2370 & 8630 & 331 & 50 & 1.49 & 26.3 & -. & 58.7 & 266 & 20000 & -. & 220 & .. & - & .04 & -. \\
\hline & May-86 & 597 & $\mathbf{U}$ & 13000 & 27000 & 2200 & & 26 & 46 & - & 410 & 1300 & 71000 & - & 580 & & 20 & .39 & 11 \\
\hline & Oct-86 & 610 & $\mathbf{F}$ & 8300 & 20000 & 1500 & 81 & 16 & 70 & 12 & 240 & 900 & 55900 & 40 & 480 & -- & 120 & 162 & - \\
\hline & Oct-86 & 610 & $\mathrm{U}$ & 7500 & 20000 & 1500 & 81 & 14 & 120 & 12 & 210 & 910 & & & & & & & \\
\hline \multirow{5}{*}{$\begin{array}{c}1979 \\
(4 S E-280 R C)\end{array}$} & $0 c t-83$ & 690 & F & 12400 & 33700 & 3320 & 8460 & 16.7 & 25.3 & 51 & 516 & 1490 & 113000 & - & 839 & & - & & \\
\hline & Jan-85 & 685 & F & 14100 & 44100 & 2790 & 180 & 12.3 & .- & 30 & 547 & 1740 & 100000 & -. & 90 & .. & 5 & .21 & .. \\
\hline & May-86 & 690 & $\mathbf{U}$ & 20000 & 49000 & 3300 & & 11 & .. & -- & 670 & 2100 & 95000 & -. & 950 & & 24 & .14 & 10 \\
\hline & Dec-86 & 690 & F & 20000 & 46000 & 3400 & 180 & 28 & - & -. & 660 & 2100 & 125000 & .. & 1200 & - & .4 & 300 & - \\
\hline & Dec-86 & 690 & $\mathbf{U}$ & 19000 & 44000 & 3300 & 180 & 28 & 47 & - & 640 & 2000 & & & & & & & \\
\hline \multirow{5}{*}{$\begin{array}{c}1980 \\
(4 S W-280 \mathrm{RC})\end{array}$} & Oct-83 & 690 & F & 6950 & 18300 & 1270 & 3520 & 1.6 & - & 25.7 & 277 & 841 & 62700 & - & 460 & & - & & \\
\hline & Jan-85 & 600 & F & 25200 & 60500 & 5300 & 180 & 21.3 & 21.88 & 42 & 770 & 3020 & 155000 & - & 1300 & -. & 7 & .31 & - \\
\hline & May-86 & 600 & U & 23000 & 48000 & 3600 & & 35 & 21 & -. & 650 & 2300 & 120000 & -. & 1100 & & 31 & .41 & 18 \\
\hline & Dec.86 & 590 & F & 31000 & 61000 & 5400 & 210 & 39 & 72 & -- & 930 & 3400 & 144000 & $\cdots$ & 1700 & .. & .9 & 270 & - \\
\hline & Dec-86 & 590 & U & 23000 & 45000 & 4000 & 210 & 29 & 93 & - & 680 & 2500 & & & & & & & \\
\hline \multirow{4}{*}{$\begin{array}{c}1981 \\
\text { (4W-190RC) }\end{array}$} & Oct-83 & 640 & $\mathrm{~F}$ & 7410 & 21200 & 1110 & 8830 & 1.5 & $\cdots$ & 37.4 & 302 & 890 & 68200 & - & 499 & & -- & & \\
\hline & May-86 & .400 & $\mathbf{U}$ & 20000 & 48000 & 3400 & & 31 & 130 & -- & 650 & 2000 & 120000 & -. & 950 & & 48 & .56 & 15 \\
\hline & Dec-86 & 405 & $\mathrm{~F}$ & 19000 & 42000 & 3300 & 180 & 37 & 170 & - & 630 & 2100 & 122000 & 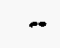 & 1300 & -- & .8 & 230 & -- \\
\hline & Dec-86 & 405 & $\mathbf{U}$ & 18000 & 40000 & 3200 & 210 & 36 & 190 & - & 620 & 2000 & & & & & & & \\
\hline
\end{tabular}


Table 4.5. Historical sample analyses for cations and anions in NHF wells (continued)

\begin{tabular}{|c|c|c|c|c|c|c|c|c|c|c|c|c|c|c|c|c|c|c|c|}
\hline \multirow[b]{2}{*}{ Station } & \multicolumn{3}{|c|}{ Sample } & \multicolumn{9}{|c|}{ Cations (mg/L) } & \multicolumn{7}{|c|}{ Anions (mg/L) } \\
\hline & Date & Depth, ft & & $\mathbf{C a}$ & $\mathrm{Na}$ & $\mathbf{M g}$ & $\mathbf{K}$ & Mn & Fe & $\mathbf{L}$ & $\mathbf{B a}$ & Sr & $\mathbf{C l}$ & $\mathrm{SO}_{4}$ & $\mathrm{Br}$ & $\mathrm{PO}_{4}$ & $\mathrm{NO}_{3}$ & $\mathbf{F}$ & I \\
\hline \multicolumn{4}{|c|}{ 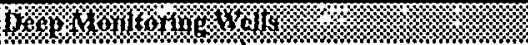 } & \% & & & & & & 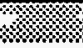 & & 湆 & & & & x & & & \\
\hline \multirow{11}{*}{$\begin{array}{c}2373 \\
(\mathrm{DM} 1-\mathrm{RM})\end{array}$} & Sep-84 & 600 & $\mathbf{F}$ & 4.65 & 394 & 1.26 & 3 & & & & & & 520 & 29 & $\cdots$ & $\cdots$ & 19 & & \\
\hline & & 795 & $\mathbf{F}$ & 628 & 2190 & 142 & 21.4 & & & & & & 4900 & - & 43 & - & 59 & & \\
\hline & & 925 & $\mathbf{F}$ & 628 & 6240 & 443 & 39.8 & & & & & & 16000 & -. & 130 & - & 240 & & \\
\hline & & 1000 & $\mathbf{F}$ & 1940 & 5450 & 381 & 36.4 & & & & & & 13000 & - & 110 & - & 240 & & \\
\hline & & 1325 & $\mathbf{F}$ & 11100 & 41800 & 2760 & 324 & & & & & & 100000 & - & 630 & - & - & & \\
\hline & Jan-85 & 600 & $\mathbf{F}$ & 25 & 1000 & 6.6 & 5.7 & .1 & - & .28 & .32 & 2.1 & 1500 & 10 & 11 &.- & - & .53 & - \\
\hline & & 795 & $\mathbf{F}$ & 3000 & 7900 & 550 & 46 & 14 & 2.3 & - & 34 & 300 & 20000 & - & 170 & - & 290 & .46 & - \\
\hline & & 925 & F & 7400 & 19000 & 1300 & 97 & 35 & 29 & -. & 140 & 740 & 49000 & - & 440 & -. & 700 & .48 & 7 \\
\hline & & 1000 & $\mathbf{F}$ & 7400 & 19000 & 1300 & 92 & 35 & 28 & - & 140 & 740 & 52000 & .. & 380 & -. & 640 & .46 & 6 \\
\hline & & 1325 & $\mathbf{F}$ & 12000 & 44000 & 2800 & 340 & 13 & 43 & 28 & 4.1 & 1000 & 120000 & 79 & 710 & - & 6 & .26 & 5 \\
\hline & Jan-86 & 1085 & $\mathbf{U}$ & 11000 & 37000 & 1300 & 330 & 1.1 & 3.1 & 55 & 8.6 & 870 & 91000 & 330 & 750 & 19 & 66 & .06 & 11 \\
\hline \multirow{11}{*}{$\begin{array}{c}2374 \\
(\mathrm{DM} 2-\mathrm{RM})\end{array}$} & Sep-84 & 640 & $F$ & 1120 & 3760 & 278 & 32.3 & & & & & 125 & 8100 & - & 66 & -- & - & & \\
\hline & & 840 & $\mathbf{F}$ & 7390 & 17500 & 1400 & 70.5 & & & & 154 & 821 & 47000 & -. & 410 & - & 650 & & \\
\hline & & 960 & F & 5920 & 14300 & 1120 & 79.5 & & & & 122 & 568 & 50000 & - & 360 & - & 750 & & \\
\hline & & 1040 & $\mathbf{F}$ & 5140 & 12900 & 982 & 78.5 & & & & 98.8 & 568 & 32000 & - & 290 & -- & 660 & & \\
\hline & & 1400 & $\mathbf{F}$ & 12900 & 50700 & 2850 & 352 & & & & 23.5 & 12400 & 120000 & - & 980 & .. & -- & & \\
\hline & Jan-85 & 640 & $\mathbf{F}$ & 8800 & 20000 & 1600 & 110 & 30 & 36 & - & 180 & 940 & 61000 & 380 & 620 & - & 683 & .48 & 5 \\
\hline & & 840 & $\mathbf{F}$ & 14000 & 34000 & 2500 & 170 & 53 & 58 & - & 310 & 1500 & 87000 & -- & 760 & -- & 1200 & .44 & 7 \\
\hline & & 960 & F & 15000 & 35000 & 2600 & 140 & 58 & 65 & - & 320 & 1600 & 76000 & -. & 680 & .- & 1500 & .51 & 7 \\
\hline & & 1040 & $\mathbf{F}$ & 12000 & 33000 & 2200 & 140 & 47 & 38 & -- & 260 & 1300 & 72000 & - & 680 & - & 1300 & .4 & 6 \\
\hline & & 1400 & $F$ & 26000 & 99000 & 5200 & 430 & 32 & 100 & 69 & 32 & 2200 & 163000 & 108 & 1400 & .. & $\ldots$ & .46 & 19 \\
\hline & Jan-86 & 1250 & $\mathrm{U}$ & 15000 & 57000 & 2300 & 890 & $=$ & 6.5 & 88 & 28 & 1400 & 130000 &.- & 1500 & 19 & 9.2 & .11 & 12 \\
\hline \multirow{9}{*}{$\begin{array}{c}2375 \\
\text { (DM3A-PV) }\end{array}$} & Sep-84 & 610 & $\mathbf{F}$ & .85 & 179 & .24 & 1.08 & & & &.- & .02 & 160 & 34 & - & - & - & & \\
\hline & & 850 & F & 1.09 & 211 & .24 & 1.41 & & & & -- & .03 & 200 & 34 & -- & -- & .. & & \\
\hline & & 940 & $\mathbf{F}$ & 2.2 & 198 & .4 & 1.67 & & & & -. & .04 & 190 & 43 & - & .- & .- & & \\
\hline & & 1100 & $\mathbf{F}$ & & 2100 & 73.9 & 27.1 & & & & .26 & 18.1 & 3700 & 85 & 28 & - & .. & & \\
\hline & Jan-85 & 610 & F & 6.3 & 280 & 1.4 & 1.4 & .04 & - & - & .02 & .44 & 330 & 40 & 2 & - & .. & 1.4 & - \\
\hline & & 850 & $F$ & 1.9 & 350 & .44 & 1.7 & .01 & -. & - & -. & .08 & 450 & 100 & 2 & -- & - & 1.9 & .. \\
\hline & & 940 & $\mathrm{~F}$ & 2.5 & 370 & .65 & 2.4 & .01 & -. & - & - & .09 & 440 & 153 & 2 & -- & - & 2 & - \\
\hline & & 1100 & $\mathrm{~F}$ & 1200 & 9000 & 340 & 77 & 3.9 & 98 & - &. & 78 & 19000 & 230 & 140 & - & - & .81 & .. \\
\hline & Jan-86 & 875 & $\mathrm{U}$ & 2800 & 12000 & 260 & 77 & 3 & 23 & 11 & 1.5 & 210 & 24000 & 522 & 210 & 22 & - & .08 & - \\
\hline 2952 (DM1-RT) & Jan-86 & 700 & $\mathrm{U}$ & 13000 & 30000 & 2700 & 740 & 3.4 & 5.3 & 28 & 89 & 1300 & 98000 & - & 840 & 28 & 18 & .6 & 0 \\
\hline 2953 (DM3-RT) & $\mathrm{Jan}-86$ & 550 & $\bar{U}$ & 11000 & 35000 & 2900 & 140 & 7 & 100 & 33 & 290 & 1300 & 93000 & - & 950 & 20 & 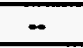 & .59 & 12 \\
\hline 2954 (DM1-PV) & Jan-86 & 1050 & $\mathbf{U}$ & 22000 & 59000 & 4100 & 240 & 140 & 170 & 55 & 680 & 2300 & 150000 & - & 1400 & 17 & 442 & .46 & 19 \\
\hline 2955 (DM2-PV) & Jan-86 & 1050 & $\mathrm{U}$ & 26000 & 57000 & 4400 & 230 & 100 & 130 & 51 & 610 & 2600 & 150000 & $\because$ & 2100 & 17 & 1991 & .28 & 18 \\
\hline
\end{tabular}

Compiled from: Haase, Switek, and Stow 1987 and Switek, Haase, and Stow 1987.

Note: "--" indicates analyte was not detected. A blank indicates no analysis was performed.

$\alpha$ - alpha and $\beta$ - beta; $U$ - unfiltered and F - filtered 
Table 4.4. Historical sample analyses for $\mathrm{pH}$, alkalinity, conductivity, total dissolved solids, and temperature

\begin{tabular}{|c|c|c|c|c|c|c|c|c|c|}
\hline \multirow[b]{2}{*}{ Station } & \multicolumn{3}{|c|}{ Sample } & \multicolumn{2}{|c|}{$\mathrm{pH}$} & \multirow{2}{*}{$\begin{array}{c}\text { Alkalinity } \\
(\mathrm{mg} \mathrm{HCO} / \mathrm{L})\end{array}$} & \multirow{2}{*}{$\begin{array}{l}\text { Conductivity } \\
(\mu \mathrm{S} / \mathrm{cm})\end{array}$} & \multirow{2}{*}{$\begin{array}{c}\text { TDS } \\
(\mathrm{mg} / \mathrm{L})\end{array}$} & \multirow{2}{*}{$\begin{array}{l}\text { Temp } \\
\left({ }^{\circ} \mathrm{C}\right)\end{array}$} \\
\hline & Date & \multicolumn{2}{|l|}{ Depth, ft } & Field & Laboratory & & & & \\
\hline 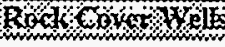 & 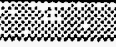 & ?. & & m. & s: : & 溇 & 11. & s. & \\
\hline 1969 & Oct-83 & 640 & $F$ & & 3.48 . & - & & 147091 & \\
\hline \multirow[t]{4}{*}{ (4E-200RC) } & $\operatorname{Jan}-85$ & 640 & F & 4.7 & & 6 & 184000 & 182549 & 10.9 \\
\hline & May-86 & 640 & $\mathbf{U}$ & 4.1 & & - & - & 193840 & \\
\hline & Dec-86 & 635 & F & & & 2 & & 188459 & \\
\hline & Dec-86 & 635 & $\mathrm{U}$ & 4.9 & & & 62500 & 195060 & 14.4 \\
\hline \multirow{4}{*}{$\begin{array}{c}1971 \\
(4 \mathrm{~N}-200 \mathrm{RC})\end{array}$} & Oct-83 & 570 & $\mathrm{~F}$ & & 7.62 & 47.1 & & 6408 & \\
\hline & May-86 & 400 & $\mathrm{U}$ & 5.2 & & - & 168600 & 162770 & 17.9 \\
\hline & Dec-86 & 365 & $\mathbf{F}$ & & & - & & 168275 & \\
\hline & Dec-86 & 365 & $\mathrm{U}$ & 1.7 & & & 169300 & 166206 & 11.7 \\
\hline \multirow{5}{*}{$\begin{array}{c}1973 \\
(4 \mathrm{NE}-280 \mathrm{RC})\end{array}$} & Oct-83 & 570 & $\mathbf{F}$ & & 4.35 & .2 & & 166779 & \\
\hline & Jan-85 & 580 & F & 4.7 & & 4 & 179800 & 159363 & 11.2 \\
\hline & May-86 & 580 & $\mathrm{U}$ & 5.9 & & - & 176200 & 160920 & 17.9 \\
\hline & Dec-86 & 570 & $\mathrm{~F}$ & & & - & & 146345 & \\
\hline & Dec-86 & 570 & $\mathrm{U}$ & 4.6 & & & 137500 & 147490 & 15.1 \\
\hline \multirow{4}{*}{$\begin{array}{c}1974 \\
(4 \mathrm{NW}-340 \mathrm{RC})\end{array}$} & Oct-83 & 570 & $F$ & & 7.36 & 16.3 & & 37646 & \\
\hline & May-86 & 580 & $U$ & 4.9 & & - & 177700 & 169220 & 16.4 \\
\hline & Dec-86 & 570 & $\mathbf{F}$ & & & 2 & & 169974 & \\
\hline & Dec-86 & 570 & $\mathbf{U}$ & 4.5 & & & 166100 & 168886 & 13.6 \\
\hline \multirow{5}{*}{$\begin{array}{c}1976 \\
(4 \mathrm{~S}-200 \mathrm{RC})\end{array}$} & Oct-83 & 690 & $F$ & & 6.67 & 14.3 & & 51597 & \\
\hline & $\operatorname{Jan}-85$ & 590 & $\mathbf{F}$ & 5.3 & & - & 47800 & 31876 & 10.7 \\
\hline & May-86 & 597 & $\mathbf{U}$ & 4.9 & & - & 139200 & 195000 & 18.2 \\
\hline & Oct-86 & 610 & $F$ & & & .5 & & 87822 & \\
\hline & Oct-86 & 610 & $\mathrm{U}$ & 5.4 & & & 108200 & 87051 & 14.2 \\
\hline \multirow{5}{*}{$\begin{array}{c}1979 \\
\text { (4SE-280RC) }\end{array}$} & Oct-83 & 690 & $F$ & & 4.29 & 3 & & 165265 & - \\
\hline & Jan-85 & 685 & $F$ & 6.3 & & 2 & 109200 & 164177 & 10.4 \\
\hline & May-86 & 690 & $\mathrm{U}$ & 6.2 & & - & 190300 & 171020 & 16.8 \\
\hline & Dec-86 & 690 & $F$ & & & 6 & & 198887 & \\
\hline & Dec-86 & 690 & $\mathrm{U}$ & 5.5 & & & 179500 & 195731 & 14.8 \\
\hline \multirow{5}{*}{$\begin{array}{c}1980 \\
(4 \mathrm{SW}-280 \mathrm{RC})\end{array}$} & Oct-83 & 690 & $F$ & & 7.49 & 20.9 & & 90798 & \\
\hline & Jan-85 & 600 & $\mathrm{~F}$ & 4.4 & & 1 & - & 251090 & 10.8 \\
\hline & May-86 & 600 & $\mathrm{U}$ & 4.8 & & - & 194200 & 198650 & 17.5 \\
\hline & Dec-86 & 590 & F & & & - & & 248032 & \\
\hline & Dec-86 & 590 & $\mathrm{U}$ & 4 & & & 170800 & $221493^{\circ}$ & 15.2 \\
\hline \multirow{4}{*}{$\begin{array}{c}1981 \\
(4 \mathrm{~W}-190 \mathrm{RC})\end{array}$} & Oct-83 & 640 & $\mathbf{F}$ & & 7.53 & 19.2 & & 99611 & \\
\hline & May-86 & 400 & $\mathbf{U}$ & 6.8 & & - & 188900 & 195000 & 20.4 \\
\hline & Dec-86 & 405 & $\mathbf{F}$ & & & - & & 190947 & \\
\hline & Dec-86 & 405 & $\mathrm{U}$ & 3.9 & & & 180000 & 187786 & 13.5 \\
\hline \multicolumn{4}{|c|}{ 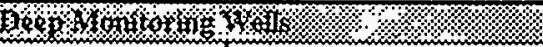 } & (a) & & (3) & צx. & (3) & ; \\
\hline \multirow{11}{*}{$\begin{array}{c}2373 \\
\text { (DM1-RM) }\end{array}$} & Sep-84 & 600 & $\mathrm{~F}$ & 7.9 & & 105 & 693 & 923 & 20 \\
\hline & & 795 & $\mathrm{~F}$ & 6 & & 90 & 14640 & 7881 & 17.4 \\
\hline & & 925 & $F$ & 5.8 & & 72 & 40400 & 23351 & 19 \\
\hline & & 1000 & $\mathrm{~F}$ & 6 & & 79 & 34600 & 20807 & 20.4 \\
\hline & & 1325 & $F$ & 5.1 & & - & 175400 & 155984 & 20.6 \\
\hline & Jan-85 & 600 & $\mathrm{~F}$ & 7.6 & & 110 & 3880 & 2539 & 12.1 \\
\hline & & 795 & F & 5.8 & & 70 & 47000 & 31796 & 10.2 \\
\hline & & 925 & $\mathrm{~F}$ & 5.3 & & 8 & 91500 & 77537 & 11.1 \\
\hline & & 1000 & $\mathbf{F}$ & 5.3 & & 10 & 105000 & 80532 & 10.8 \\
\hline & & 1325 & $\mathrm{~F}$ & 4.9 & & $=$ & 172500 & 180140 & 10.2 \\
\hline & Jan-86 & 1085 & $\mathrm{U}$ & 8.4 & & 20 & 167700 & 141500 & 13.5 \\
\hline
\end{tabular}


Table 4.4. Historical sample analyses for $\mathrm{pH}$, alkalinity, conductivity, TDS, and temperature (continued)

\begin{tabular}{|c|c|c|c|c|c|c|c|c|c|}
\hline \multirow[b]{2}{*}{ Station } & \multicolumn{3}{|c|}{ Sample } & \multicolumn{2}{|c|}{$\mathrm{pH}$} & \multirow{2}{*}{$\begin{array}{c}\text { Alkalinity } \\
\left(\mathrm{mg} \mathrm{HCO}_{3} / \mathrm{L}\right)\end{array}$} & \multirow{2}{*}{$\begin{array}{c}\text { Conductivity } \\
(\mu \mathrm{S} / \mathrm{cm})\end{array}$} & \multirow{2}{*}{$\begin{array}{c}\text { TDS } \\
(\mathrm{mg} / \mathrm{L})\end{array}$} & \multirow{2}{*}{$\begin{array}{l}\text { Temp } \\
\left({ }^{\circ} \mathrm{C}\right)\end{array}$} \\
\hline & Date & Depth, & & Field & Laboratory & & & & \\
\hline \multicolumn{4}{|c|}{ 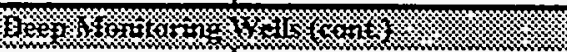 } & & 4 & & & & \\
\hline \multirow{11}{*}{$\begin{array}{c}2374 \\
(\mathrm{DM} 2-\mathrm{RM})\end{array}$} & Sep-84 & 640 & $F$ & 6.1 & & 72 & 22900 & 13415 & 18.4 \\
\hline & & 840 & $\mathbf{F}$ & 5.6 & & 15 & 5400 & 74182 & 19.4 \\
\hline & & 960 & $\mathbf{F}$ & 5.7 & & 27 & 83200 & 71988 & 19.4 \\
\hline & & 1040 & $\mathrm{~F}$ & 5.8 & & 27 & 77500 & 51669 & 17.7 \\
\hline & & 1400 & $\mathrm{~F}$ & 5.2 & & - & 189700 & 199202 & 20.2 \\
\hline & Jan-85 & 640 & $F$ & 5.4 & & 7 & 42200 & 92450 & 10.5 \\
\hline & & 840 & $\mathbf{F}$ & 5.2 & & - & 68400 & 139170 & 11.5 \\
\hline & & 960 & F & 5.2 & & - & 49700 & 130340 & 10.3 \\
\hline & & 1040 & $\mathbf{F}$ & 5.2 & & - & 47800 & 120640 & 11.3 \\
\hline & & 1400 & $F$ & 4.6 & & - & 77400 & 295830 & 11.7 \\
\hline & Jan-86 & 1250 & $\mathrm{U}$ & 10.3 & & 366 & 75700 & 141500 & 10.4 \\
\hline \multirow{9}{*}{$\begin{array}{c}2375 \\
\text { (DM3A-PV) }\end{array}$} & Sep-84 & 610 & $F$ & 8.9 & & 113 & 865 & 341 & 16.9 \\
\hline & & 850 & $\mathrm{~F}$ & 8.1 & & 123 & 979 & 414 & 18.6 \\
\hline & & 940 & $\mathbf{F}$ & 8.3 & & 115 & $982^{\circ}$ & 392 & 16.5 \\
\hline & & 1100 & $F$ & 6.8 & & 90 & 3810 & 5919 & 18.3 \\
\hline & Jan-85 & 610 & $\bar{F}$ & 8.7 & & 114 & 471 & 620 & 11.2 \\
\hline & & 850 & $\mathrm{~F}$ & 8.5 & & 135 & 619 & 804 & 12.6 \\
\hline & & 940 & $\mathbf{F}$ & 8.3 & & 136 & 1860 & 816 & 12.8 \\
\hline & & 1100 & $\mathbf{F}$ & 7.8 & & 128 & 18210 & 29695 & 11.3 \\
\hline & Jan-86 & 875 & $\mathrm{U}$ & 6.9 & & 60 & 63000 & 39347 & 12.8 \\
\hline 2952 (DM1-RT) & Jan-86 & 700 & $\mathrm{U}$ & 6.8 & & 3 & 160200 & 145740 & 12.4 \\
\hline 2953 (DM3-RT) & Jan-86 & 550 & $\mathrm{U}$ & 4.6 & & - & 61000 & 143340 & 9 \\
\hline 2954 (DM1-PV) & Jan-86 & 1050 & $\mathrm{U}$ & 4.4 & & - & - & 237640 & 10 \\
\hline 2955 (DM2-PV) & Jan-86 & 1050 & $\bar{U}$ & 4.3 & & - & - & 240230 & 13.9 \\
\hline
\end{tabular}

Compiled from: Haase, Switek, and Stow 1987 and Switek, Haase, and Stow 1987.

Note: "-" indicates analyte was not detected. A blank indicates no analysis was performed.

$\alpha$ - alpha and $\beta$ - beta; $U$ - unfiltered and F - filtered 
Table 4.5. Historical sample analyses for cations and anions in New Hydrofracture Facility wells

\begin{tabular}{|c|c|c|c|c|c|c|c|c|c|c|c|c|c|c|c|c|c|c|c|}
\hline \multirow[b]{2}{*}{ Station } & \multicolumn{3}{|c|}{ Sample } & \multicolumn{9}{|c|}{ Cations (mg/L) } & \multicolumn{7}{|c|}{ Anions (mg/L) } \\
\hline & \multicolumn{3}{|c|}{ Date Depth, ft } & \multirow{2}{*}{ cas } & \multirow{2}{*}{$\mathrm{Na}$} & \multirow[t]{2}{*}{$\mathbf{M g}$} & \multirow[t]{2}{*}{$\mathbf{K}$} & \multirow{2}{*}{ Mn } & \multirow[t]{2}{*}{$\mathrm{Fe}$} & \multirow[t]{2}{*}{$\mathbf{L}$} & \multirow[t]{2}{*}{$\mathbf{B a}$} & \multirow[t]{2}{*}{$\mathbf{S r}$} & \multirow[t]{2}{*}{$\mathbf{C I}$} & \multirow[t]{2}{*}{ so, } & \multirow[t]{2}{*}{$\overline{B r}$} & $\mathbf{P O}_{4}$ & $\mathrm{NO}_{3}$ & $\mathbf{F}$ & I \\
\hline \multirow{6}{*}{$\begin{array}{c}1969 \\
\text { (4E-200RC) }\end{array}$} & \multicolumn{3}{|c|}{ 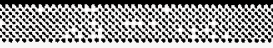 } & & & & & & & & & & & & & & & & \\
\hline & Oct-83 & 640 & $\mathbf{F}$ & 13400 & 26600 & 3040 & 11400 & 17.7 & 23 & 40.6 & 498 & 1620 & 101000 & - & 933 & & - & & \\
\hline & Jan-85 & 640 & $\mathbf{F}$ & 12200 & 44500 & 2880 & 160 & 13.7 & 5.12 & 58.8 & 599 & 1540 & 120000 & - & 830 & - & 5 & .46 & - \\
\hline & May-86 & 640 & $\mathbf{U}$ & 19000 & 48000 & 3300 & & 30 & 39 & - & 660 & 2000 & 120000 & - & 880 & & 32 & .33 & 18 \\
\hline & Dec-86 & 635 & $\mathbf{F}$ & 17000 & 42000 & 3100 & 170 & 30 & 32 & - & 610 & 1800 & 122000 & - & 1300 & - & 2 & 400 & - \\
\hline & Dec-86 & 635 & $\mathbf{U}$ & 19000 & 46000 & 3400 & 180 & 33 & 73 & - & 660 & 2000 & & & & & & & \\
\hline 1971 & Oct-83 & 570 & $F$ & 717 & 2180 & 168 & 954 & 1.4 & - & 4 & 18.9 & 79 & 3200 & - & 45 & & - & & \\
\hline$(4 \mathrm{~N}-200 \mathrm{RC})$ & May-86 & 400 & $\mathbf{U}$ & 16000 & 44000 & 2900 & & 20 & 25 & - & 500 & 1600 & $97000^{\circ}$ & - & 770 & & 28 & .03 & 15 \\
\hline & Dec-86 & 365 & $\mathbf{F}$ & 15000 & 41000 & 2800 & 140 & 20 & 42 & - & 480 & 1600 & 106000 & - & 900 & - & 3.01 & 280 & - \\
\hline & Dec-86 & 365 & $\mathbf{U}$ & 14000 & 40000 & 2800 & 150 & 20 & 70 & - & 470 & 1500 & & & & & & & \\
\hline 1973 & Oct-83 & 570 & $\mathrm{~F}$ & 15500 & 27700 & 3120 & 17300 & 10.9 & - & 53.2 & 478 & 1880 & 117000 & - & 1101 & & - & & \\
\hline (4NE-280RC) & $\operatorname{Jan}-85$ & 580 & $\mathbf{F}$ & 12200 & 41600 & 2770 & 130 & 25.5 & 13.6 & 25.7 & 463 & 1530 & 100000 & - & 800 & - & 4 & .29 & - \\
\hline & May-86 & 580 & $\mathbf{U}$ & 16000 & 44000 & 3000 & & 33 & 47 & - & 530 & 1600 & 95000 & - & 790 & & 34 & .3 & 16 \\
\hline & Dec-86 & 570 & $F$ & $12000^{\circ}$ & 33000 & 2400 & 160 & 29 & 49 & -- & 450 & 1400 & 95700 & - & 950 & - & 2.6 & 190 & - \\
\hline & Dec-86 & 570 & $\mathbf{U}$ & 12000 & 34000 & 2500 & 160 & 30 & 110 & .. & 450 & 1400 & & & & & & & \\
\hline 1974 & Oct-83 & 570 & $\mathbf{F}$ & 2820 & 8890 & 1930 & 1430 & $\ldots$ & - & 13.4 & 119 & 297 & 23400 & $\overline{-}$ & 190 & & - & & \\
\hline (4NW-340RC) & May-86 & 580 & $\mathbf{U}$ & 17000 & 46000 & 3200 & & 19 & 69 & - & 550 & 1700 & 100000 & - & 770 & & 54 & .44 & 11 \\
\hline & Dec-86 & 570 & $\mathbf{F}$ & 15000 & 43000 & 3000 & 140 & 22 & 77 & - & 530 & 1600 & 10600 & - & 450 & $\ldots$ & .71 & 140 & - \\
\hline & Dec-86 & 570 & $\mathrm{U}$ & 15000 & 42000 & 2900 & 140 & 22 & 99 & - & 520 & 1600 & & & & & & & \\
\hline 1976 & Oct-83 & 690 & $F$ & 4810 & 11400 & 736 & 5190 & 1.6 & - & 18.7 & 162 & 551 & 33700 & $\therefore$ & 238 & & - & & \\
\hline (4S-200RC) & Jan-85 & 590 & F & 2370 & 8630 & 331 & 50 & 1.49 & 26.3 & -. & 58.7 & 266 & 20000 & - & 220 & - & - & .04 & - \\
\hline & May-86 & 597 & $\mathbf{U}$ & 13000 & 27000 & 2200 & & 26 & 46 & - & 410 & 1300 & 71000 & -. & 580 & & 20 & .39 & 11 \\
\hline & Oct-86 & 610 & $\mathrm{~F}$ & 8300 & 20000 & 1500 & 81 & 16 & 70 & 12 & 240 & 900 & 55900 & 40 & 480 & -- & 120 & 162 & -- \\
\hline & Oct-86 & 610 & $\mathrm{U}$ & 7500 & 20000 & 1500 & 81 & 14 & 120 & 12 & 210 & 910 & & & & & & & \\
\hline 1979 & Oct-83 & 690 & $F$ & 12400 & 33700 & 3320 & 8460 & 16.7 & 25.3 & 51 & 516 & 1490 & 113000 & - & 839 & & -- & & \\
\hline (4SE-280RC) & Jan-85 & 685 & $\mathbf{F}$ & 14100 & 44100 & 2790 & 180 & 12.3 &.- & 30 & 547 & 1740 & 100000 & - & 90 & -. & 5 & .21 & -- \\
\hline & May-86 & 690 & $\mathbf{U}$ & 20000 & 49000 & 3300 & & 11 & .. & -- & 670 & 2100 & 95000 & -. & 950 & & 24 & .14 & 10 \\
\hline & Dec-86 & 690 & $\mathrm{~F}$ & 20000 & 46000 & 3400 & 180 & 28 & 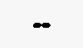 & -- & 660 & 2100 & 125000 & -. & 1200 & -- & .4 & 300 & - \\
\hline & Dec-86 & 690 & $\mathbf{U}$ & 19000 & 44000 & 3300 & 180 & 28 & 47 & $\ldots$ & 640 & 2000 & & & & & & & \\
\hline 1980 & Oct-83 & 690 & F & 6950 & 18300 & 1270 & 3520 & 1.6 & - & 25.7 & 277 & 841 & 62700 & - & 460 & &.- & & \\
\hline (4SW-280RC) & Jan-85 & 600 & I & 25200 & 60500 & 5300 & 180 & 21.3 & 21.88 & 42 & 770 & 3020 & 155000 & -- & 1300 & -- & 7 & .31 & - \\
\hline & May-86 & 600 & $\mathbf{U}$ & 23000 & 48000 & 3600 & & 35 & 21 & - & 650 & 2300 & 120000 & - & 1100 & & 31 & .41 & 18 \\
\hline & Dec-86 & 590 & F & 31000 & 61000 & 5400 & 210 & 39 & 72 & - & 930 & 3400 & 144000 & - & 1700 & -- & .9 & 270 & - \\
\hline & Dec-86 & 590 & $\mathrm{U}$ & 23000 & 45000 & 4000 & 210 & 29 & 93 & - & 680 & 2500 & & & & & & & \\
\hline 1981 & Oct-83 & 640 & $F$ & 7410 & 21200 & 1110 & 8830 & 1.5 & - & 37.4 & 302 & 890 & 68200 & - & 499 & & 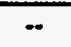 & & \\
\hline (4W-190RC) & May-86 & .400 & $\mathbf{U}$ & 20000 & 48000 & 3400 & & 31 & 130 & - & 650 & 2000 & 120000 & - & 950 & & 48 & .56 & 15 \\
\hline & Dec-86 & 405 & $\mathbf{F}$ & 19000 & 42000 & 3300 & 180 & 37 & 170 & - & 630 & 2100 & 122000 & -. & 1300 & -- & .8 & 230 & - \\
\hline & Dec-86 & 405 & $\mathbf{U}$ & 18000 & 40000 & 3200 & 210 & 36 & 190 & $\ldots$ & 620 & 2000 & & & & & & & \\
\hline
\end{tabular}


Table 4.5. Historical sample analyses for cations and anions in NHF wells (continued)

\begin{tabular}{|c|c|c|c|c|c|c|c|c|c|c|c|c|c|c|c|c|c|c|c|}
\hline \multirow[b]{2}{*}{ Station } & \multicolumn{3}{|c|}{ Sample } & \multicolumn{9}{|c|}{ Cations (mg/L) } & \multicolumn{7}{|c|}{ Anlons (mg/L) } \\
\hline & Date & Depth, & & $\mathrm{Ca}$ & $\mathrm{Na}$ & $\mathbf{M g}$ & $\mathbf{K}$ & $\mathbf{M n}$ & $\mathrm{Fe}$ & $\mathbf{L}$ & $\mathbf{B a}$ & $\mathbf{S r}$ & $\mathbf{C I}$ & $\mathrm{SO}_{4}$ & $\mathrm{Br}$ & $\mathrm{PO}_{4}$ & $\mathrm{NO}_{3}$ & F & I \\
\hline \multicolumn{4}{|c|}{ Wo } & & \% & & & & 19. & 丽 & & \% & & & & 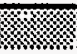 & m. & 烈 & \\
\hline \multirow{11}{*}{$\begin{array}{c}2373 \\
(\mathrm{DM} 1-\mathrm{RM})\end{array}$} & Sep-84 & & $\mathrm{F}$ & 4.65 & 394 & 1.26 & 3 & & & & & & 520 & 29 & $\cdots$ & $\cdots$ & 19 & & \\
\hline & & 795 & $\mathbf{F}$ & 628 & 2190 & 142 & 21.4 & & & & & & 4900 & - & 43 & - & 59 & & \\
\hline & & 925 & $\mathbf{F}$ & 628 & 6240 & 443 & 39.8 & & & & & & 16000 & .. & 130 & - & 240 & & \\
\hline & & 1000 & $\mathbf{F}$ & 1940 & 5450 & 381 & 36.4 & & & & & & 13000 & .. & 110 & - & 240 & & \\
\hline & & 1325 & $\mathrm{~F}$ & 11100 & 41800 & 2760 & 324 & & & & & & 100000 & - & 630 & - & - & & \\
\hline & Jan-85 & 600 & $\mathbf{F}$ & 25 & 1000 & 6.6 & 5.7 & .1 & - & .28 & .32 & 2.1 & 1500 & 10 & 11 & $\cdots$ & $\infty$ & .53 & 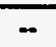 \\
\hline & & 795 & F & 3000 & 7900 & 550 & 46 & 14 & 2.3 & - & 34 & 300 & 20000 & - & 170 & - & 290 & .46 & - \\
\hline & & 925 & $\mathbf{F}$ & 7400 & 19000 & 1300 & 97 & 35 & 29 & - & 140 & 740 & 49000 & - & 440 & - & 700 & .48 & 7 \\
\hline & & 1000 & $\mathbf{F}$ & 7400 & 19000 & 1300 & 92 & 35 & 28 & - & 140 & 740 & 52000 & -. & 380 & .. & 640 & .46 & 6 \\
\hline & & 1325 & $\mathbf{F}$ & 12000 & 44000 & 2800 & 340 & 13 & 43 & 28 & 4.1 & 1000 & 120000 & 79 & 710 & - & 6 & .26 & 5 \\
\hline & Jan-86 & 1085 & $\mathbf{U}$ & 11000 & 37000 & 1300 & 330 & 1.1 & 3.1 & 55 & 8.6 & 870 & 91000 & 330 & 750 & 19 & 66 & .06 & 11 \\
\hline \multirow{11}{*}{$\begin{array}{c}2374 \\
(\mathrm{DM} 2-\mathrm{RM})\end{array}$} & Sep-84 & 640 & $F$ & 1120 & 3760 & 278 & 32.3 & & & & & 125 & 8100 & - & 66 & $\cdots$ & - & & \\
\hline & & 840 & $\mathbf{F}$ & 7390 & 17500 & 1400 & 70.5 & & & & 154 & 821 & 47000 & - & 410 & - & 650 & & \\
\hline & & 960 & F & 5920 & 14300 & 1120 & 79.5 & & & & 122 & 568 & 50000 & -- & 360 & - & 750 & & \\
\hline & & 1040 & $\mathbf{F}$ & 5140 & 12900 & 982 & 78.5 & & & & 98.8 & 568 & 32000 & - & 290 & -- & 660 & & \\
\hline & & 1400 & $\mathbf{F}$ & 12900 & 50700 & 2850 & 352 & & & & 23.5 & 12400 & 120000 & - & 980 & .. & 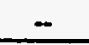 & & \\
\hline & Jan-85 & 640 & $\mathbf{F}$ & 8800 & 20000 & 1600 & 110 & 30 & 36 & - & 180 & 940 & 61000 & 380 & 620 & 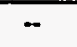 & 683 & .48 & 5 \\
\hline & & 840 & $\mathbf{F}$ & 14000 & 34000 & 2500 & 170 & 53 & 58 & .. & 310 & 1500 & 87000 & -- & 760 & -. & 1200 & .44 & 7 \\
\hline & & 960 & F & 15000 & 35000 & 2600 & 140 & 58 & 65 & -. & 320 & 1600 & 76000 & - & 680 & -- & 1500 & .51 & 7 \\
\hline & & 1040 & $\mathbf{F}$ & 12000 & 33000 & 2200 & 140 & 47 & 38 & -- & 260 & 1300 & 72000 & - & 680 & - & 1300 & .4 & 6 \\
\hline & & 1400 & $\mathbf{F}$ & 26000 & 99000 & 5200 & 430 & 32 & 100 & 69 & 32 & 2200 & 163000 & 108 & 1400 & .. & - & .46 & 19 \\
\hline & Jan-86 & 1250 & $\mathrm{U}$ & 15000 & 57000 & 2300 & 890 & - & 6.5 & 88 & 28 & 1400 & 130000 & - & 1500 & 19 & 9.2 & .11 & 12 \\
\hline \multirow{9}{*}{$\begin{array}{c}2375 \\
\text { (DM3A-PV) }\end{array}$} & Sep-84 & 610 & $\bar{F}$ & .85 & 179 & .24 & 1.08 & & & & - & .02 & 160 & 34 & $\overline{-}$ & - & - & & \\
\hline & & 850 & $\mathbf{F}$ & 1.09 & 211 & .24 & 1.41 & & & & -. & .03 & 200 & 34 & - & .. & - & & \\
\hline & & 940 & $\mathrm{~F}$ & 2.2 & 198 & .4 & 1.67 & & & & - & .04 & 190 & 43 & - & -. & - & & \\
\hline & & 1100 & $F$ & & 2100 & 73.9 & 27.1 & & & & .26 & 18.1 & 3700 & 85 & 28 & - & - & & \\
\hline & Jan-85 & 610 & F & 6.3 & 280 & 1.4 & 1.4 & .04 & - & - & .02 & .44 & 330 & 40 & 2 & -. & -. & 1.4 & - \\
\hline & & 850 & F & 1.9 & 350 & .44 & 1.7 & .01 & -. & -. & -- & .08 & 450 & 100 & 2 & - & - & 1.9 & - \\
\hline & & 940 & $\mathbf{F}$ & 2.5 & 370 & .65 & 2.4 & .01 & -- & - & - & .09 & 440 & 153 & 2 & - & - & 2 & - \\
\hline & & 1100 & $\mathrm{~F}$ & 1200 & 9000 & 340 & 77 & 3.9 & 98 & - & -- & 78 & 19000 & 230 & 140 & - & - & .81 & - \\
\hline & Jan-86 & 875 & $\mathrm{U}$ & 2800 & 12000 & 260 & 77 & 3 & 23 & 11 & 1.5 & 210 & 24000 & 522 & 210 & 22 & - & .08 & - \\
\hline 2952 (DM1-RT) & Jan-86 & 700 & $\mathrm{U}$ & 13000 & 30000 & 2700 & $740^{\circ}$ & 3.4 & 5.3 & 28 & 89 & 1300 & 98000 & - & 840 & 28 & 18 & .6 & 0 \\
\hline 2953 (DM3-RT) & Jan-86 & 550 & $\mathbf{U}$ & 11000 & 35000 & 2900 & 140 & 7 & 100 & 33 & 290 & 1300 & 93000 & $\cdots$ & 950 & 20 & - & .59 & 12 \\
\hline 2954 (DM1-PV) & Jan-86 & 1050 & $\mathbf{U}$ & 22000 & 59000 & 4100 & 240 & 140 & 170 & 55 & 680 & 2300 & 150000 & - & 1400 & 17 & 442 & .46 & 19 \\
\hline 2955 (DM2-PV) & Jan-86 & 1050 & $\mathbf{U}$ & 26000 & 57000 & 4400 & 230 & 100 & 130 & 51 & 610 & 2600 & 150000 & - & 2100 & 17 & 1991 & .28 & 18 \\
\hline
\end{tabular}

Compiled from: Haase, Switek, and Stow 1987 and Switek, Haase, and Stow 1987.

Note: "--" indicates analyte was not delected. A blank indicates no analysis was performed.

$\alpha$ - alpha and $\beta$ - beta; $U$ - unfiltered and F - filtered

InST_ANCXIS 
Table 4.6. Historical sample analyses for radionuclides in New Hydrofracture Facility wells

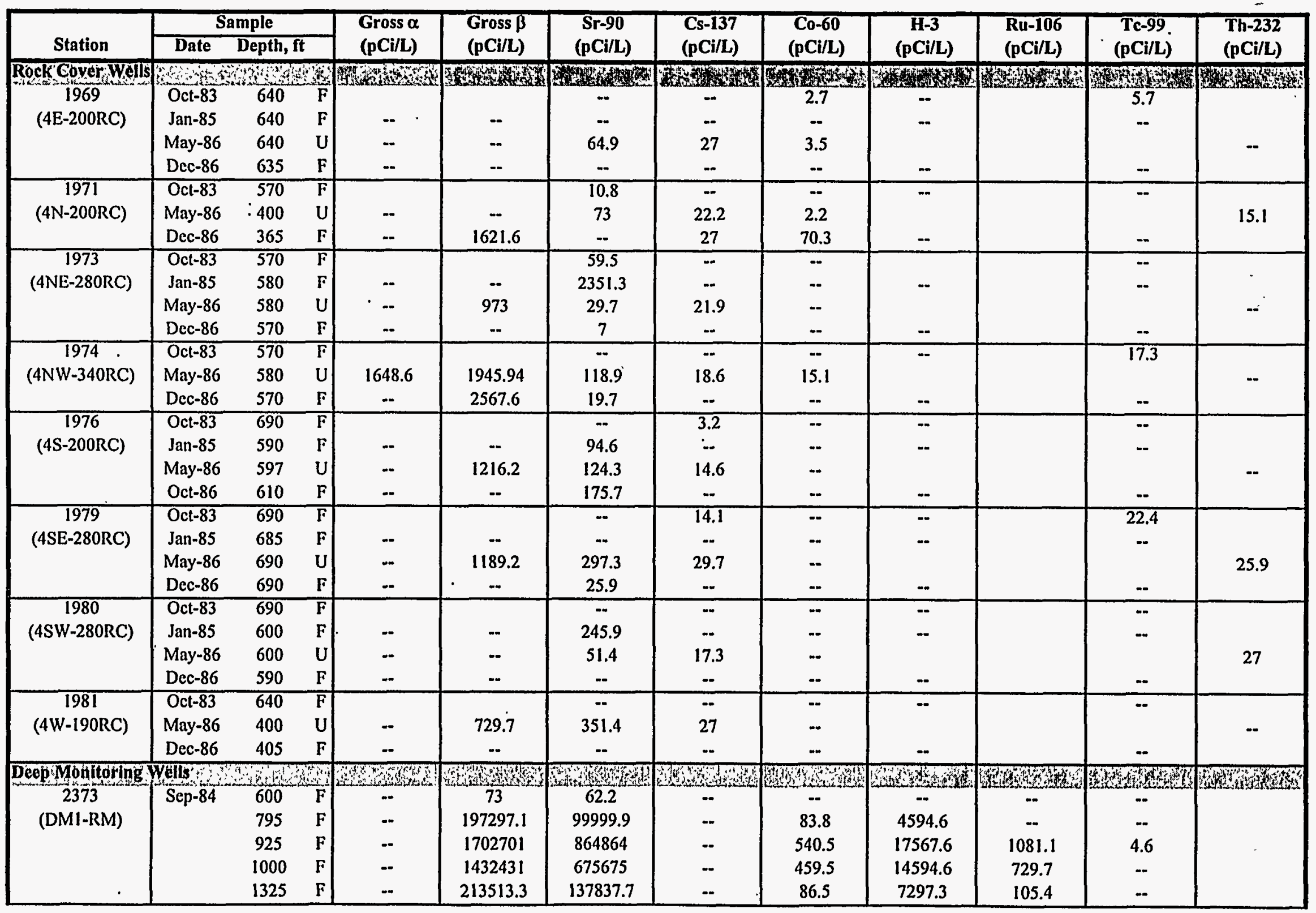


Table 4.6. Historical sample analysies for radionuclides in NHF wells (continued)

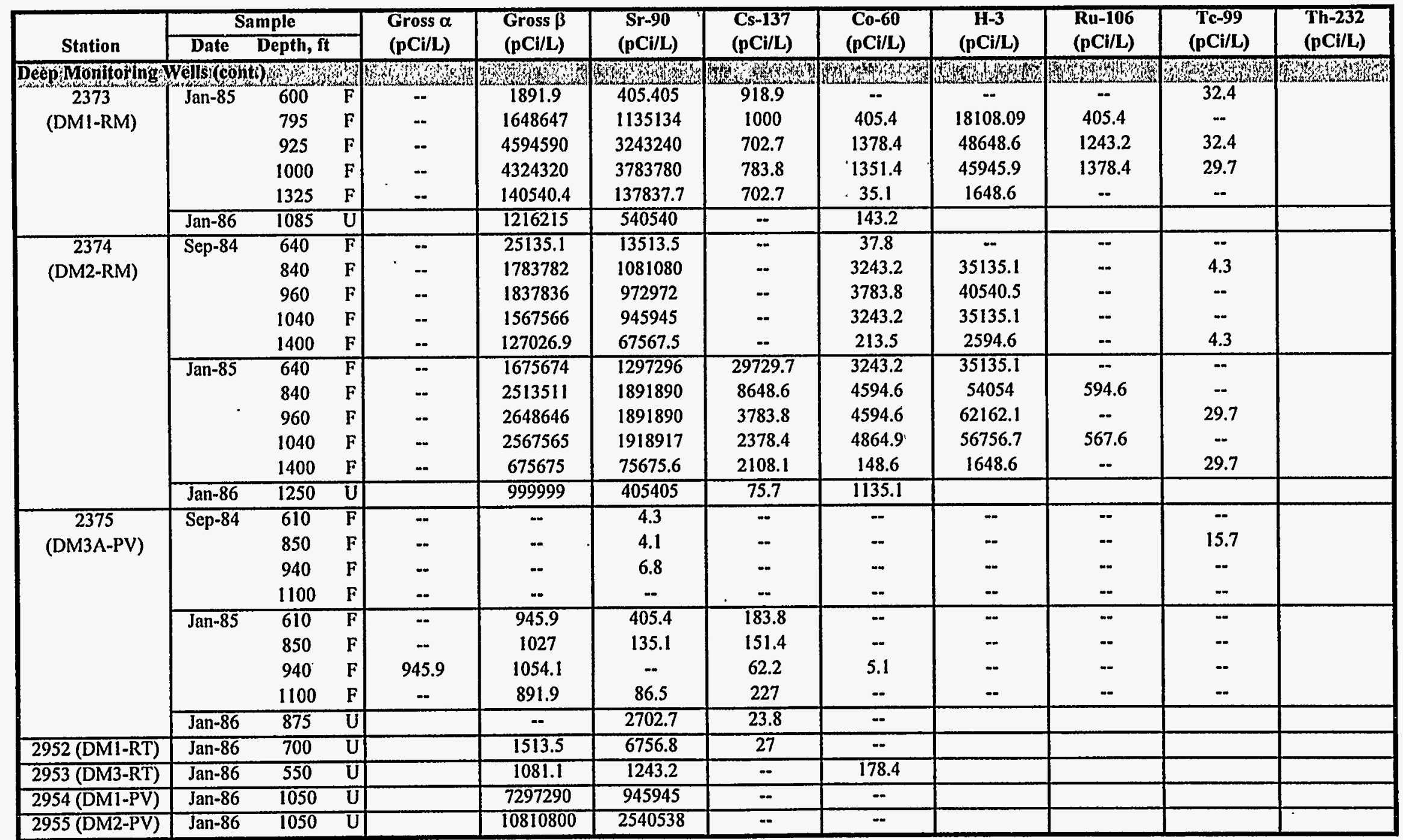

Note: "--" indicates analyte was not detected. A blank indicates no analysis was performed.

$\alpha-$ alpha and $\beta$ - beta; $U$ - unfiltered and $F$ - filtered 
Table 4.7. Bleedback data collected during injections and mix ratio evaluation at the New Hydrofracture Facility

\begin{tabular}{|c|c|c|c|c|c|c|c|c|}
\hline & & Estimated & Bleedback & & & Total & Low Mix & \\
\hline $\begin{array}{l}\text { Injection } \\
\text { ID No. }\end{array}$ & $\begin{array}{l}\text { Injection } \\
\text { Date }\end{array}$ & $\begin{array}{l}\text { Total Water } \\
\text { Injected (gal) }\end{array}$ & $\begin{array}{l}\text { Water } \\
\text { (gal) }\end{array}$ & $\begin{array}{l}\text { Percent } \\
\text { of Total }\end{array}$ & $\begin{array}{l}\text { Dominant } \\
\text { Radionuclide }\end{array}$ & $\begin{array}{l}\text { Waste } \\
\text { Batches }\end{array}$ & $\begin{array}{l}\text { Ratio } \\
\text { Batches }\end{array}$ & $\begin{array}{l}\text { Percent of } \\
\text { Total }\end{array}$ \\
\hline \multicolumn{9}{|c|}{ 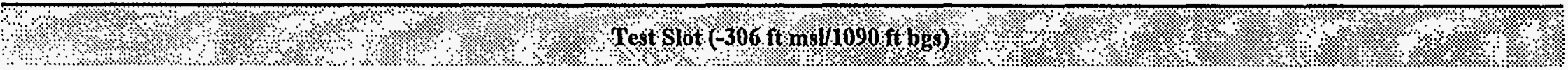 } \\
\hline Test Injection & June 1974 & 95,780 & 0 & 0 & ${ }^{198} \mathrm{Au}$ & - & 一 & - \\
\hline \multicolumn{9}{|c|}{ Slot No. $1(-285 \mathrm{ft} \mathrm{ms} / / 1069 \mathrm{ft}$ bgs) } \\
\hline ILW-19 & June 1982 & 12,210 & 6,000 & 49 & ${ }^{137} \mathrm{Cs}$ & 7 & 1 & 14 \\
\hline \multirow[t]{2}{*}{ SI-1 } & August 1982 & 51,825 & 5,300 & 20 & ${ }^{90} \mathrm{Sr}$ & 12 & 7 & 58 \\
\hline & & & & & ${ }^{137} \mathrm{Cs}$ & 6 & 6 & 100 \\
\hline SI-2 & September 1982 & 10,080 & 2,800 & 28 & ${ }^{90} \mathrm{Sr}$ & 8 & 3 & 38 \\
\hline SI-3 & October 1982 & 20,370 & 10,700 & 53 & ${ }^{90} \mathrm{Sr}$ & 13 & 1 & 8 \\
\hline \multicolumn{9}{|c|}{ Injection well (1968) shut down for recovery operations between December 1982 and March 1983} \\
\hline 3 & :. & \%., & $109 \%$ & timis & (5) & ?... & 1.:. & 1.. \\
\hline SI-4 & April 1983 & 17,750 & 7,680 & 43 & ${ }^{90} \mathrm{Sr}$ & 12 & 2 & 17 \\
\hline SI-5 & May 1983 & 11,595 & 1,570 & 13 & ${ }^{90} \mathrm{Sr}$ & 8 & 0 & 0 \\
\hline $\mathbb{L W}-20$ & June 1983 & 8,420 & 1,100 & 13 & ${ }^{137} \mathrm{Cs}$ & 5 & 1 & 20 \\
\hline SI-6 & July 1983 & 14,175 & 520 & 4 & ${ }^{90} \mathrm{Sr}$ & 8 & 0 & 0 \\
\hline SI-7 & August 1983 & 10,980 & 480 & 4 & ${ }^{90} \mathrm{Sr}$ & 6 & 0 & 0 \\
\hline (1) & (1.1. & 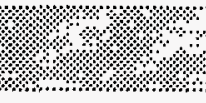 & slot No. & 8 & (8) & & & \% \\
\hline SI-8 & October 1983 & 10,660 & 500 & 5 & ${ }^{90} \mathrm{Sr}$ & 7 & 3 & 43 \\
\hline SI-9 & December 1983 & 10,110 & 240 & 2 & ${ }^{90} \mathrm{Sr}$ & 8 & 1 & 13 \\
\hline SI-10 & January 1984 & 13,155 & 0 & 0 & ${ }^{90} \mathrm{Sr}$ & 5 & 0 & 0 \\
\hline ILW-21 & January 1984 & 12,750 & 0 & 0 & ${ }^{90} \mathrm{Sr}$ & 5 & 5 & 100 \\
\hline
\end{tabular}





\section{REGULATORY SETTING}

P\&A of the NHF observation, rock cover, and deep monitoring wells will be subject to several federal and state regulations, depending on the actions undertaken. These regulations are discussed briefly below and listed in Table 5.1. Four reports discuss P\&A: Well P\&A Plan for WAG 6 at ORNL (Stansfield and Huff 1992), P\&A Plan for Wells and Coreholes at ORNL (Stansfield et al. 1992), P\&A Procedures for the Oak Ridge Y-12 Plant (Haase and Gillis 1989), and Plugging and Abandonment Options Analysis Report for the OHF Wells in Waste Area Grouping 10, (BMI 1995c).

\subsection{WASTE CHARACTERIZATION}

Any wastes generated during P\&A must be characterized before disposal to determine whether they are solid, low-level, or mixed waste.

\subsection{WASTE DISPOSAL}

Wastes generated by P\&A activities must be stored, treated, and/or disposed of at an appropriate facility, depending on the waste characterization. All wastes must meet the waste acceptance criteria (WAC) of the receiving facility. Wellbore fluids, decontamination fluids, and any other P\&A-generated water will be transported to an ORNL facility for treatment before disposal. Any other hazardous or nonhazardous solid waste generated will be managed in accordance with proper waste management procedures. Disposal of low-level radioactive waste materials must be in accordance with DOE requirements.

Investigation-derived waste (IDW) management options under CERCLA may be a consideration for wastes generated during P\&A of NHF wells if the action is determined to be a CERCLA response. Management practices must be protective of human health and the environment and comply with all applicable or relevant and appropriate requirements (ARARs). EPA's Office of Solid Waste and Emergency Response Directive 9345.3-03FS presents an overview of IDW management options. In general, the approach should be based on the contaminants, concentrations, volume, and potentially affected media, and the IDW may be managed in accordance with federal and state ARARs or may be left at the area of contamination (AOC) where it was generated.

Table 5.1 lists the requirements for waste characterization and disposal, depending on waste type (e.g., RCRA or low level). If left at the AOC until a final disposal option is selected, the IDW should be managed in a manner compatible with the waste characteristics and best management practices should be used to control fugitive emissions.

\subsection{FUGITIVE EMISSIONS}

The ORR fugitive emissions permit incorporates by reference TDEC requirements for control of fugitive dust. Site preparation activities could elevate particulate concentrations, and TDEC-Air Pollution Control has promulgated regulations governing fugitive dust emissions (TDEC Rules, Chap. 1200-3-8-.010). An operator must take reasonable precautions to prevent particulate matter from becoming airborne. 
The ORNL plant permit lists general plant activities that may emit fugitive dust. The approved permit covers environmental restoration activities, soil borrow, etc., including non-point-source fugitive emissions from remediation. To ensure compliance, use of ambient air monitoring stations may be recommended by the ORNL Environmental Compliance Section as a best management practice.

Subpart $\mathrm{H}$ of 40 Code of Federal Regulations (CFR) 61 addresses atmospheric radionuclide emissions from DOE facilities and applies to point-source airborne emissions. EPA has issued a final National Emission Standards for Hazardous Air Pollutants (NESHAPs) rule [54 Federal Register (FR) 51654, December 15, 1989] that limits emissions of radionuclides to the ambient air from DOE facilities to amounts that would not cause any member of the public to receive an effective dose equivalent of $10 \mathrm{mrem} / \mathrm{year}$ or more (40 CFR 61.92). 40 CFR 61.93(b)(4)(i) requires radiological emission measurements at all release points that have a potential to discharge radionuclides into the air in quantities that could cause an effective dose equivalent in excess of one (1) percent of the standard ( $0.1 \mathrm{mrem} / \mathrm{year})$. All radionuclides that could contribute greater than 10 percent of the standard ( $1 \mathrm{mrem} /$ year) for a release point will be measured. Currently, non-point-source fugitive radionuclide emissions are estimated by ambient air monitoring stations. These fugitive radionuclide sources are listed in the annual NESHAPs report for each plant, but specific emission estimates are not quantified. Collaboration with ORNL Environmental Compliance Section is recommended to ensure that no significant radionuclide emissions will occur during plugging activities.

\subsection{STORM WATER CONTROL}

Storm water discharges from activities at industrial sites involving construction operations that result in the disturbance of 5 acres or more are included in the final rule for National Pollutant Discharge Elimination System (NPDES) permits. Construction activities include clearing, grading, and excavation ( $40 \mathrm{CFR}$ 122). Disturbances of less than 5 acres are anticipated; therefore, application for an NPDES permit is not anticipated.

\subsection{PLUGGING AND ABANDONMENT}

\subsubsection{Overview}

TDEC UIC regulations classify all groundwater as usable for domestic water supply. However, the UIC definition of an underground source of drinking water (USDW) is "an aquifer or its part that:

- currently supplies any public water system; or

- contains a sufficient quantity of groundwater to supply a public water system; and

\section{$5-4$}

(3) Near the base and above the injection zone. Four of the 21 wells at NHF penetrate the injection zone and extend into the underlying Rome Formation. These wells should be plugged at the lower Pumpkin Valley Shale Formation contact. This contact occurs at depths of 1,075 to $1,120 \mathrm{ft}$. Nine of the wells penetrate the injection horizon (upper Pumpkin Valley Shale) and should be sealed at least from the Rutledge Limestone/upper Pumpkin Valley Shale contact back to the surface. This contact occurs at depths of 718 to $817 \mathrm{ft}$, which corresponds roughly to the approximate depth of the brine-containing aquiclude (Hatcher et al. 1992). The remaining 10 wells (rock cover and deep monitoring Wells 2952 and 2953), with total depths of 580 to 
Table 5.1. Regulations for plugging and abandonment of WAG 10 wells $^{a}$

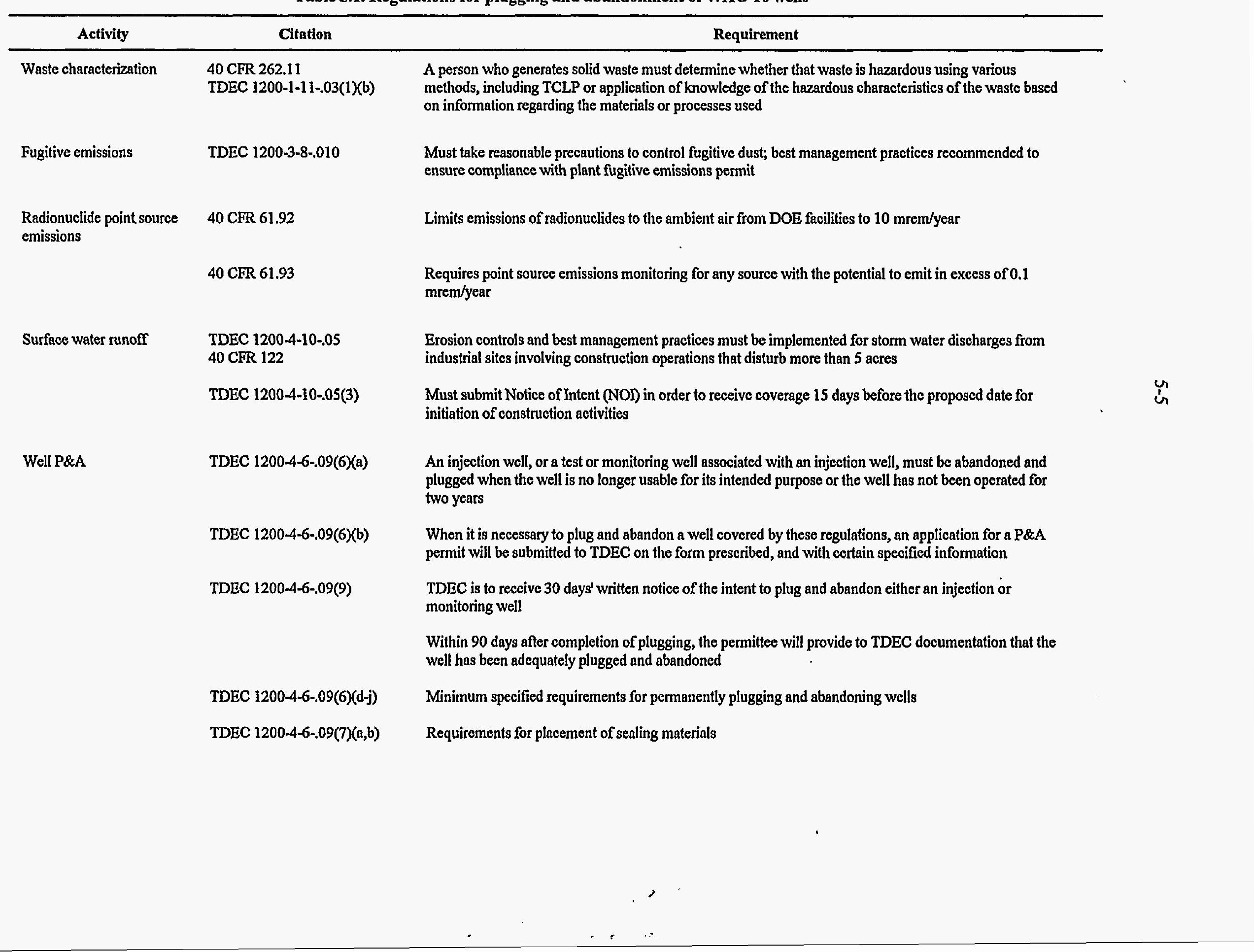


Table 5.1. Regulations for plugging and abandonment of WAG 10 wells ${ }^{a}$ (continued)

\begin{tabular}{|c|c|c|}
\hline Activity & Citation & Requirement \\
\hline & TDEC $1200-4-6-.09(8)(b)$ & Requirements for sealing any monitoring well that extends to the top of the shallowest injection \\
\hline \multicolumn{3}{|l|}{$\begin{array}{l}\text { Waste storage and } \\
\text { disposal }\end{array}$} \\
\hline $\begin{array}{l}\text { Wastewater generated } \\
\text { during plugging activities }\end{array}$ & $\begin{array}{l}40 \text { CFR } 122 \\
\text { TDEC } 1200-4-5\end{array}$ & $\begin{array}{l}\text { Must meet NPDES permitting requirements for point source discharges; must meet waste acceptance } \\
\text { criteria of receiving facility }\end{array}$ \\
\hline \multirow[t]{2}{*}{ Low-level waste } & DOE Order 5400.5 & $\begin{array}{l}\text { Low-level waste-containing materials that do not exceed the residual surface contamination guidelines, in } \\
\text { concert with the ALARA process, may be released to the public without restrictions on use }\end{array}$ \\
\hline & $\begin{array}{l}\text { DOE Moratorium on LLW } \\
\text { Shipments } \\
\text { ("no rad added policy") } \\
\text { DOE Order } 5820.2 \mathrm{~A}\end{array}$ & $\begin{array}{l}\text { Low-level waste must be disposed of on site; if off-site disposal is required due to lack of capacity, } \\
\text { disposal must be to a DOE facility; disposal must be according to DOE and Energy Systems waste } \\
\text { management procedures }\end{array}$ \\
\hline Nonhazardous waste & $\begin{array}{l}40 \text { CFR } 258 \\
\text { TDEC 1200-1-7-.01 et seq. }\end{array}$ & $\begin{array}{l}\text { Disposal of nonhazardous waste may be in a Subtitle } D \text { permitted landfill if it meets the permit } \\
\text { requirements }\end{array}$ \\
\hline Mixed hazardous waste & DOE/EPA Mixed Waste-FFCA & $\begin{array}{l}\text { Allows storage of mixed wastes at the ORR for periods longer than one year pending development of } \\
\text { treatment capacity }\end{array}$ \\
\hline
\end{tabular}

${ }^{a}$ This summary represents major regulatory issues for well plugging and abandonment activities. It is an overview of the requirements and does not list all the requirements of the regulations cited.

Notes:

ALARA $=$ as low as reasonably achievable.

$\mathrm{CFR}=$ Code of Federal Regulations.

$\mathrm{CWA}=$ Clean Water Act.

DOE $=$ U.S. Department of Energy.

$\mathrm{EPA}=$ Environmental Protection Agency.

FFCA $=$ Federal Facility Compliance Agreement

$\mathrm{LDR}=$ land disposal restriction.

NPDES = National Pollutant Discharge Elimination System.

ORR = Oak Ridge Reservation.

RCRA = Resource Conservation and Recovery Act.

$\mathrm{TDEC}=$ Tennessee Department of Environment and Conservation. 
Table 5.2. Minimum specified state requirements for P\&A of UIC-qualified wells, TDEC 1200-4-6-.09, Paragraphs (G)(d) through (8)(b)

(6) Plugging and Abandonment Standards. [(a), (b), and (c) are not shown.]

(d) Any well that is to be permanently plugged and abandoned shall be completely filled and sealed in such a manner that vertical movement of fluid into or between formation(s) containing ground water classified pursuant to rule $1200-4-6-.05(1)$ through the bore hole is not allowed.

(c) As a minimum, permanent seals must be placed in the bore hole opposite (1) the lowermost confining bed, and (2) each intermediate bed between successive formation(s) containing ground water classified pursuant to rule 12004-6-.05(1).

(f) Seals intended to prevent vertical movement of water in a well bore hole shall be composed of cement, sand-andcement, or concrete or other sealing materials demonstrated to the satisfaction of the Department to be effective.

(g) The minimum length of a seal required in (f), above, shall be 20 feet.

(h) The bore hole above the uppermost formation(s) containing ground water classified pursuant to rule 1200-4-6$.05(1)$ shall be filled with materials less permeable than the surrounding undisturbed formations, the uppermost five (5) feet of the bore hole (at land surface) shall be filled with a material appropriate to the intended use of the land. (I) The materials used to fill spaces between well seals shall be filled with disinfected dimensionally stable materials, compacted mechanically if necessary to avoid later settlement except that cement, cement and sand, and concrete do not require disinfection. Disinfection of well filling materials shall be accomplished by using chlorine compounds such as sodium hypochlorite or calcium hypochlorite.

(j) Temporary bridges may be used to avoid having to fill very deep holes below the deepest point at which a permanent seal is required. Temporary bridges used to provide a base for a permanent seal shall consist of materials approved by the Department.

(7) Placement of sealing materials.

(a) Approved sealing materials used in abandonment operations shall be introduced at the bottom of the well or interval to be sealed and placed progressively upward to the top of the well. All such sealing materials shall be placed in such a way as to avoid segregation or dilution of the sealing materials. The method of emplacing materials shall be approved by the Department. Dumping sealing material from the top of the well shall not be allowed.

(b) Permanent seals shall be placed in wells or bore holes opposite confining beds between aquifers which are identifiable as, or are suspected of being, hydraulically separated under natural, undisturbed conditions. After the required seal has been installed, the remainder of the confining zone between formations containing ground water classified pursuant to rule 1200-4-6-.05(1) may be filled with sand, sand and gravel, or other rock material acceptable to the Department.

(8) Special Conditions. [(c) is not shown.]

(a) The permanent sealing of flowing wells or wells that have a positive shut-in pressure head at the land surface shall be accomplished only after the wells have been prepared in such a way as to prevent any backflow of water or other fluids at the land surface. This can be accomplished by introducing high specific gravity fluids at the bottom of the bore hole and filling the hole with the fluid until all flow ceases or the shut-in pressure is reduced to zero. If the displaced fluid constitutes a contaminant, special handling will be required to avoid any threat to ground water classified pursuant to rule 1200-4-6-.05(1).

(b) Prior to abandonment, any Class I or Class III well or any monitoring well that extends to the top of the shallowest injection zone shall be sealed from the top of the shallowest injection zone to the land surface with neat cement grout or an approved equivalent cementitious material such as neat cement with a maximum of 5 percent by weight of commercially processed bentonite. 


.




\section{PLUGGING AND ABANDONMENT CONSIDERATIONS}

Several options are available for plugging and abandonment of the NHF wells. This chapter describes the response actions and their implementation and identifies the waste management concerns for well P\&A.

\subsection{GENERAL RESPONSE ACTIONS}

This chapter identifies and briefly describes general response actions applicable to permanent closure of the wells and screens them against specified criteria to select the most appropriate actions for detailed evaluation. The number of response actions identified is limited because this report focuses on actions that meet the requirements specified in the regulations and have been applied and proven to be suitable and practicable. Limiting identified actions facilitates the process of discussing and selecting preliminary response actions. The screening process is performed for the response actions rather than at the level of detail required for individual technologies.

Potentially applicable general response actions for the hydrofracture well P\&A are containment and removal. Each action is screened against three broad criteria:

- effectiveness-ability to meet the intent of the regulations and the P\&A objectives,

- implementability - technical and administrative feasibility, and

- cost-used here as a relative ranking (e.g., high, medium, and low).

Table 6.1 summarizes key considerations of the response action screening process.

\subsubsection{Identification of Response Actions}

Containment. Containment involves placing plugs in a wellbore in a way that protects fresh water and isolates the injection zone. General references on this subject are written by the American Petroleum Institute (1993) and by D. K. Smith (1987). The plugs may fill up intervals in an openhole or casing string and any behind-casing void spaces, which would limit potential fluid migration inside the casing/open interval. They may also fill in the annular space between the casing and the formation:

- near the ground surface to prevent interaction between surface water and groundwater;

- below the freshwater system to protect it from upward-moving contaminants;

- near the bottom of the casing (or at the casing shoe) to isolate the openhole interval;

- above the injection zone (at the base of the injection zone, if necessary) to isolate that zone; or

- at a casing stub (i.e., the remnant of a casing string when the casing above it has been cut away and pulled out of the hole) to prevent flow to or from the remnant casing string or the annular space below the stub.

Filling the wellbore (open interval and cased hole) with a column of cement is commonly substituted for using a number of individual isolation plugs. The groundwater in the NHF area, however, is highly saline and corrosive. The casing left in place will eventually corrode and may provide a pathway for contaminant migration. 
If a cased well has poor external mechanical integrity (i.e., the annular grout seal is absent or inadequate, and significant fluid movement is occurring in channels in the annular section), the casing can be perforated or a window can be milled out of the casing prior to cementing. Figure 6.1 shows example schematics of plugs in a casing that is perforated. A number of perforating devices are available to punch holes through the casing and grout and re-establish contact with the formation. A window can be made in the casing by milling out a portion of the casing and annular grout, and penetration into the formation material can be accomplished with an underreaming tool.

Two techniques are recommended for applying a cement squeeze: bradenhead or bullhead squeezes. The following definitions of squeeze methods are from the American Petroleum Institute (API 1993).

- Bradenhead squeeze: the process by which hydraulic pressure is applied to a casing, workstring, or tubing to force fluids (such as cement) outside the wellbore. Annular returns may be prevented by closing the casing head valves. A packer is not run in the well, so the inner casing wall is exposed to pumping pressures.

- Bullhead squeeze: the process by which hydraulic pressure is applied to a working string or tubing to force fluids outside the wellbore. Annular returns are prevented by a packer set in the casing above the perforated and/or openhole interval. The packer shields the inner casing wall from exposure to pumping pressures.

The cement squeeze method is the application of hydraulic pressure to cement slurry after it has been pumped to the desired interval. Although cement squeezing can be used for any isolation plug, it is often used for plugs in open intervals or leaking casings. The hydraulic pressure dehydrates the slurry, and a high-strength filter cake is formed in the perforations, against the formation face, or in open channels or fractures.

Removal. Removal is defined as extraction of casing and annular grout seal before the wellbore is filled with a column of cement. The casing must be detached from the formation and annular grout seal (usually done by milling or washing over the casing) before the casing is extracted. Removal is included as a general response action because it reflects the procedures outlined in early P\&A plans (TWO 1986 and 1987) for cased hydrofracture wells that intersected the grout sheets.

\subsubsection{Screening of Response Actions Efficiency}

By definition, both the containment and removal response actions meet the P\&A requirements specified in the regulations (Sect. 5.5). Both response actions would be effective over the long term in stopping potential vertical transport of contaminants along wellbores and isolating the injection/disposal zone, and the active shallow freshwater zone would be protected from high-saline formation fluid migration or surface water influx. The removal response action goes beyond the minimum P\&A requirements in that a full column of cement in a borehole with the casing and grout removed isolates all formations intercepted by the wellbore and prevents fluid movement between all those formations. Table 6.2 compares P\&A methods.

Compatibility with the regulations also means that conflict with surface land use would be minimized for both response actions (i.e., wellhead assemblies, casing, and grout will be removed to $5 \mathrm{ft}$ below ground level, and soil will be replaced to ground level).

Remedial activities must also comply with regulations regarding fugitive emissions, storm water control, and waste disposal (Sects. 5.2 through 5.4). Both response actions recognize potential short- 
term and localized environmental impacts from fugitive emissions and runoff, but the impacts are mitigated by engineering practices such as dust suppression techniques, monitoring, and erosion control measures. Contaminated materials and other wastes removed during the response actions will be covered or contained to prevent contaminant dispersion in the environment; these wastes will then be properly disposed of in accordance with the WAC of the receiving facility.

Although both response actions can be implemented in compliance with the regulations, containment and removal differ in meeting the following P\&A objectives.

- Minimization of the amount of waste materials generated during the P\&A procedures. The contaminated fluids currently in each well would be displaced to the surface by both response actions as cement or drilling fluids are inserted in the wells. However, removal would generate significantly more waste materials (i.e., cement, casing, formation materials, and drilling fluids) than containment.

- Minimization of contaminant leaching from wells and boreholes. Containment isolates critical intervals and prevents migration in boreholes, but it does not remove casing, annular grout, or formation material immediately surrounding the borehole. If any of this material is contaminated, a potential source of contaminants remains downhole after closure. It is difficult to quantify the long-term significance of downhole contamination without well-specific information about contaminant type and half-life, depth, extent, leaching rate, and migration potential.

Implementation. Both containment and removal are technically feasible, but there would be technical limitations or difficulties for a few wells in either case.

Containment requires that tools be inserted into the wells to perforate the casing or mill out windows where cement plugs can be set to isolate downhole intervals. These tools are not generally available for casings with inside diameters of $<2.5$ in., although there are some exceptions in nonmechanical perforators, which can be used in casings with diameters as small as 1.5 in.

Containment also requires log interpretation, well construction information, and pressure tests to assess the mechanical integrity of the wells (e.g., whether there are any significant leaks in the casing or void spaces behind the casing) and whether formation fluids are migrating in the annular space outside the casing. The logs and pressure tests cannot prove the null hypothesis (i.e., good mechanical integrity or no external flow) but can only provide indications of poor integrity or external flow. In addition, the determination of mechanical integrity and fluid migration potential is qualitative and based on experience of the interpreter.

While not constrained by casing diameter, removal does require that the washover pipe or milling tools follow the path of the original wellbore. Occasionally, however, the removal apparatus will deviate from the wellbore path into virgin formation, and only by trial and error can the original path be recovered and the washover or milling continue. In such cases, P\&A becomes a game of patience with little regard for project schedule or cost (Weeren et al. 1984). Logs and well construction data provide valuable information for implementing the removal response action.

Removal also requires that casing and grout be extracted from the ground surface downward. As the extraction proceeds downhole and contaminated areas (such as the injection zone) are reached, the contamination is brought to the surface with the drilling mud, greatly increasing the risk of crosscontaminating the shallow formations that are now unprotected and increasing WM concerns. 
Highly corroded or poor-integrity casing can create problems for both the containment and removal options; however, the problems can be more severe for removal if the casing becomes hung up in the hole during extraction. Fishing out pipe and/or tools can be difficult and time consuming.

Both containment and removal are administratively feasible, although gaining the necessary approvals to implement removal would be incrementally more difficult than for containment because of DOE/ORNL policies for waste minimization and as low as reasonably achievable worker exposures. In the decision-making process, these policies will be weighed against the possible environmental benefit from extracting all contaminated materials from the wellbore in the removal response action.

ORNL has established administrative procedures for closure of many of its inactive wells, and these procedures will serve as a template for $\mathrm{DOE}$ as it incorporates lessons learned and finalizes administrative procedures for the entire ORR. The procedures will specify planning documents that should accompany any request/submittal for well P\&A. The planning process should be included in any P\&A schedule because preimplementation decisions may need to be made with regard to such issues as compliance, NEPA, safety, and WM.

Federal and state agencies will also be involved with ORNL and DOE in the administration of the hydrofracture well closures. P\&A planning will use the applicable regulations as guidance and will meet the intent of the federal and state permitting process for well closures.

Services and materials required for either containment or removal are available and, therefore, should not affect implementability of these actions. A contractor with appropriate qualifications would perform the well P\&A, but many of the support functions could be supplied by ORNL. These support functions could include site preparation, WM (waste characterization, treatment, transportation, and disposal), laboratory analysis of samples, medical, firefighting, security, administrative and compliance oversight, and $\mathrm{H} \& \mathrm{~S}$, as needed. Interface would be required between the outside contractor and the ORNL support groups to successfully plug and abandon the wells.

Removal of selected wells would require considerable expertise in milling, "fishing" for tools, drilling, and rig management. The potential for radiation exposure and significant waste handling concerns would require higher levels of skill and training to successfully implement the P\&A and to operate the possibly modified and expensive rig components. Containment would also require considerable expertise, but perforating and squeezing for the purposes of isolation are less esoteric than casing/grout extraction.

Because equipment is expected to become contaminated during the P\&A process, ORNL may have to purchase rather than rent all or a portion of the equipment. Although it will probably be necessary to partially decontaminate and seal the equipment before transporting it from one well site to another, this should present little or no environmental risk.

Cost. In terms of both duration and cost, removal is higher than containment. The cost to plug and abandon a well by overdrilling the casing and extracting it (removal) is roughly 5 to 7 times more expensive than simply perforating the casing and cement-squeezing (containment) (BNI 1995c). The cost of removal is also roughly 1.5 to 4 times more expensive than performing containment by milling a 30-ft window and underreaming [relative estimated cost from TWO (1987)]. The cost differences are primarily due to task duration, depth to which removal is performed, and the P\&A equipment and tools required. These large differences in cost become even larger if the cost of managerial and support functions such as H\&S, compliance, decontamination, and WM is included. 
Evaluation summary. The containment response action is retained as the principal approach to hydrofracture well P\&A because of obvious benefits in lowering or minimizing waste generation, worker exposure, and cost.

The removal response action is retained for special situations where containment is difficult or not feasible to implement, and where source removal rather than source isolation is the principal concern. Where removal is deemed necessary, every effort should be made to minimize the depth to which removal is performed (e.g., to the bottom of the active fresh water flow system) and allow containment to isolate the remainder of the wellbore.

\subsection{DESCRIPTION OF IMPLEMENTATION}

\subsubsection{Approach}

The primary objective of well P\&A is to restore hydraulic separation (confinement) among strata penetrated by the wellbore. P\&A is intended to prevent upward flow of groundwater via the well casing or wellbore from the injection zone (Pumpkin Valley Shale) into overlying strata (Rutledge Limestone, Rogersville Shale, and Maryville Limestone) or underlying strata (Rome Formation); it is also intended to prevent flow into the shallow freshwater zone (upper Maryville Limestone) from other zones containing waters of different quality.

The basic approach to P\&A for the WAG 10 wells is to fill the openhole, casing, and any potential microannular flow outside the casing with cement grout. In some wells, it may be necessary to provide access to conduits outside the casing by perforating or cutting a window into the casing over specific intervals. In other wells, it may be necessary to remove some of the well casing and existing grout before filling the well with cement. For reasons noted previously, both the number of wells and the depth to which removal is applied will be minimized.

For convenience in outlining P\&A strategies, the WAG 10 NHF wells have been grouped into three main types based on external mechanical integrity (EMI; i.e., no microannular flow behind the casing) and openhole interval. Type 2 wells have been further divided into two subtypes based on casing diameter. The classification scheme used for NHF wells is consistent with that applied to the OHF wells. Table 6.3 summarizes the preferred P\&A strategy for each well type and subtype. Well and casing depth dictate slight modifications to the basic P\&A strategy for each type and subtype. follows.

Actual P\&A strategies will differ based on specific well conditions. The basic strategies are as

- Wells that have EMI (Type 1 wells) will be plugged and abandoned by filling the open hole (if any) and casing with cement. The groundwater at NHF, however, is highly saline and corrosive. Eventually, the casing left in place will corrode and may form a migration pathway. A well is considered to have EMI if it has cement behind the casing as confirmed by cement bond interpretation, and it shows no indication of behind-casing water flow as confirmed by temperature logging.

- Wells that do not have EMI [or for which EMI cannot be confirmed (Type 2 wells)] and that are large enough to accommodate standard downhole tools and equipment will be plugged and abandoned by placing cement isolation plugs in the annulus over appropriate intervals and filling with cement below, between, and above the plugs. Two isolation plugs normally will be placed: one near the bottom of the Rutledge Limestone [immediately above the upper Pumpkin 
Valley Shale (injection horizon)] and another just below the base of the shallow freshwater zone (upper Maryville Limestone). A third isolation plug may be placed near the base of the injection zone (lower Pumpkin Valley Shale) in wells that penetrate into the underlying Rome Formation. Plugs may be placed in wells with inside diameters $z 2.5$ in. by perforating the casing by explosive, chemical, hydraulic, or mechanical means; or placed in wells with inside diameters 24 in. by milling a window in the casing over the desired interval and emplacing cement. The exact depth intervals of the isolation plugs and the method of placement will depend on wellspecific conditions and the strata penetrated.

- Wells that do not have EMI [or for which EMI cannot be demonstrated (Type 2 wells)] and that have an inside diameter too small ( $<2.5 \mathrm{in}$.) to accommodate standard drilling tools will be plugged and abandoned by removing one or more casing strings and filling with cement. The casing may be removed by washing over (drilling over) the small-diameter tubing with a larger pipe. As the inner tubing is freed from the grout, sections are cut off and removed. Removal may also be by milling out the casing and grout. The minimum depth of removal will be the bottom of the shallow freshwater zone (upper Maryville Limestone). The exact depth to which casings are to be removed and the number of casings to be removed will depend on well-specific considerations and local stratigraphy.

- Openhole wells or wells whose longest casing string does not extend below the shallow freshwater zone (Type 3 wells) will be plugged and abandoned by placing cement plugs from total depth to $5 \mathrm{ft}$ bgs. These plugs will be placed in stages not to exceed the fracture gradient in the hydrofracture area. There are no openhole wells in the group associated with NHF injection activities.

Figure 6.2 shows a generalized decision tree illustrating the P\&A strategy selection process. Although not shown in either Fig. 6.2 or Table 6.3 , the containment and removal actions are not necessarily mutually exclusive. It would be possible, for example, to perforate and squeeze (containment) at the bottom of the Rutledge to isolate the injection horizon, and also remove the casing and grout down to the bottom of the upper Maryville Limestone to protect the shallow freshwater zone.

In selecting specific $P \& A$ procedures for each well, the highest priority was given to protecting the shallow freshwater zone and avoiding risk of surface releases of contaminants. Drilling and removal operations would present some degree of risk of surface releases and generate potentially hazardous materials and will be avoided whenever possible. For example, in wells where temperature logs show no movement of fluids into the shallow freshwater zone, but where the cement bond log shows poor to moderate bond, the recommended procedure, after pressure testing, is to cement the openhole and casing in place. Remedial actions to improve the cement bond are not recommended because implementation and risks are deemed disproportionate to the improvement in protecting the shallow freshwater zone. Placement of a plug near the base of the lower Pumpkin Valley Shale, however, would be recommended to minimize the possibility of downward migration of contaminants.

Some wells are keyed into the Rome Formation underlying the injection zone. Ideally, these wells would be filled with cement from total depth (TD) to $5 \mathrm{ft}$ bgs during P\&A. However, if some of these wells are open into the Rome, it is not recommended that they be cleaned out to TD by redrilling. Redrilling could bring contaminated grout to the surface and would provide minimal benefit from isolation since both the Rome and Pumpkin Valley Shale contain highly saline groundwater. Placement of a plug near the base of the lower Pumpkin Valley Shale, however, would be recommended to minimize the possibility of downward migration of contaminants. 
A significant, and possibly adequate, level of protection against future releases of contaminants to the environment could be achieved by applying to all wells the basic P\&A strategy recommended for Type 1 wells. Filling wells with cement would significantly improve containment at relatively low and minimal risk of accidental releases to the surface, but it would not ensure that continuing or future releases would not occur through possible behind-casing flow conduits.

As part of the P\&A procedure, well casings will generally be pressure tested for watertightness prior to cement placement. If the casing does not hold pressure, it will be assumed to be leaky. Wells that have EMI (Type 1 wells) as interpreted from the temperature logging but that fail the pressure test can be addressed in one of two ways.

- The well is allowed to retain its Type 1 classification because the leaks are judged to not imply vertical flow behind casing or loss of hydraulic confinement among strata. The leaks are repaired by squeezing matrix-penetrating cement over the leaky interval. Fluid migration is blocked by squeezing cement and repairing the leaks.

- The well is essentially reclassified as Type 2 because the leakiness implies that the EMI is suspect even if the temperature log does not indicate a lack of EMI. Containment (e.g., perforating and squeezing) below the shallow freshwater zone is used to reestablish formation contact.

This latter approach was followed in the Type 1 well P\&A strategies outlined in Volume 2 as a recourse should Type 1 wells fail the pressure test. It is a conservative approach that acknowledges the uncertainties associated with the well construction and log interpretation.

Evaluation of the EMI status of WAG 10 wells was based primarily on temperature logs. Other geophysical logs run during the site evaluation were used to assist in differentiating between external and internal flow and to identify suspect intervals.

Temperature in a well normally increases with depth, and the rate at which the temperature increases is called the geothermal gradient. The geothermal gradient in any particular hydrogeologic environment is controlled by the heat flow from the earth's interior, the thermal properties of the rock, and groundwater circulation. The gradient varies regionally but is essentially constant with time. Seasonal changes in surface temperature normally do not affect earth temperatures at depth.

The temperature profile measured in a well under static conditions closely reflects the natural static geothermal gradient for the area. Deviations from the static gradient in a cased well may be caused by casing leaks or by water flow outside the well casing. The magnitude, persistence, and pattern of temperature deviations provide information about their cause. The ability of the log analyst to distinguish between temperature profile disturbances caused by natural processes and those caused by casing leaks and behind-casing water flow is the basis for the assessment of EMI by temperature logging.

Panels A through $\mathrm{C}$ of Fig. 6.3 present three hypothetical examples of how the temperature gradient can be affected by water flow behind the casing. For these hypothetical situations, the temperature profile in the well is compared with the average geothermal gradient for the area. In an ideal field situation, the measured temperature profile would be compared with the actual static geothermal gradient in the same well or a nearby well, if these data are available. 
In panel $\mathrm{A}$, the temperature profile in the well generally parallels the natural gradient, and there are no distinctive changes that might indicate behind-casing water flow. The relatively small gradient changes can be correlated with the strata adjacent to the wellbore or attributed to the well construction profile. This log provides a demonstration of acceptable EMI.

In panel $\mathrm{B}$, there is a positive thermal anomaly in a cased interval, but the temperature profile above and below the anomaly generally parallels the expected gradient. A portion of the log trace is nearly vertical, indicating a very low vertical temperature gradient, characteristic of flow in a channel behind the tubing or casing. The temperature profile shows a positive (toward higher temperature) displacement compared with the expected temperature gradient. The log response may indicate that warmer water is moving upward behind the casing. Water enters and exits the channel at a more permeable stratum. Therefore, this well lacks EMI, which could imply that brine or contaminants in a lower zone could migrate into an overlying freshwater zone. A log trace like the one shown in panel B could also result from a casing leak.

Panel C is nearly a mirror image of Panel B. In this case, cooler water is being displaced downward via a channel behind the casing, causing a negative temperature anomaly. The situation shown in panel $\mathrm{C}$ also indicates a lack of EMI.

Because it is unlikely that all possible variables in a well will be known quantitatively, arriving at precise conclusions about EMI from temperature logs is difficult. Possible interferences include the following.

- Internal flows within the casing can mimic behind-casing flows. These can usually be identified from properly calibrated fluid resistance logs.

- Multiple casing strings and grout sheaths can mask subtle changes in gradient resulting from behind-casing flows.

- If behind-casing flow is very low, it may not result in an interpretable deviation from the normal geothermal gradient.

For most of the WAG 10 wells, supplementary logs (variable density, fluid resistance, spontaneous potential, caliper) are available, permitting differentiation of internal flow from behindcasing flow. Still, making a precise determination is not always possible because both external and internal flow could be occurring. Because of the known low permeabilities of most of the strata penetrated, all flows (external and internal) are expected to be very low. This factor increases the possibility that low external flow, especially in wells having multiple casing strings through the zone of interest, might go undetected. For these reasons, interpretations of EMI are intended to be conservative. That is, unless the log data clearly indicated reasonable assurance that a well had EMI, that well was classified as lacking EMI.

\subsubsection{Technologies and Methods Equipment}

The variety of well configurations at WAG 10 requires using several different kinds of surface equipment including rotary drilling rigs, coiled tubing units, wireline units, and cementing units (BNI 1995c). The capabilities, limitations, and operational considerations associated with the major types of equipment are discussed below.

Rotary drilling rig. Rotary drilling will be used to perform all drilling operations required for P\&A: drilling out obstructions in the wells, milling out casings, milling windows in casings, and underreaming sections for placement of cement plugs. All of these operations will involve advancing 
a hollow pipe (the drill pipe) that terminates in some type of cutting tool (drill bit, "junk mill", section mill, underreamer) into the ground. As the drilling progresses, additional threaded drill pipe will be added, typically in 20 - to 40 -ft sections.

Fragments of the materials being cut will be removed from the well by the drilling fluid (drilling mud), which is normally pumped down the drill pipe and returns to the surface via the annular space between the wellbore and the drill pipe. The drilling fluid is typically a mixture of water and processed clay. Other chemicals may be added to maintain required viscosity and weight. Depending on the operation being performed, the solids may be metal shavings from milling casings, old cement, native formation, or casing corrosion products. Drilling into the grout sheets is not proposed for any of the WAG 10 wells. Drilled solids (cuttings) may be removed from the circulating mud by centrifuging or sedimentation before recirculation. The drilling mud and cuttings will likely have to be treated at least as low-level radioactive waste, and the drilling fluid circulation system will have to be completely closed.

The main limitation of rotary drilling equipment is that it cannot be used for placement of isolation plugs in wells with a casing ID of less than $2.5 \mathrm{in}$. Operations can be performed only after the inner casing is removed to the depth required to place cement. Standard rotary drilling equipment also cannot be used for well evacuation and stabilization in the 1.25-in.-ID wells. Removing well casings, either by washing over casing or milling out, as described in subsequent paragraphs, would generate considerable waste and involve some inherent risks.

There will be some risk of accidental release or exposure of personnel to wastes brought to the surface; this can be minimized by using a blowout preventer on the wellhead and a rotary drilling head to provide positive surface control. The greater risk associated with these operations will be drilling out the original wellbore and being unable to regain it.

Coiled tubing. Coiled tubing, also known as reel tubing, is a viable alternative to rotary drilling equipment for plugging and abandoning wells that do not require casing removal. This equipment also provides the only safe means of evacuating the standing water or placing cement plugs in the 1.25-in. wells. Coiled tubing can be used to place cement plugs in open holes and casings and through perforations in casings, and also to conduct casing pressure tests.

Coiled tubing units are self-contained. The tubing can be from 0.75 to 3 in. in diameter and is transported on a large reel. The tubing is supplied in continuous length; there are no joints or couplings. The tubing is inserted into the well by a device called the injector, which is mounted on the wellhead. The injector straightens the tubing and pushes it into the well via a series of roller guides. A coiled tubing unit typically includes a crane, mounted on the same truckbed as the tubing reel, to mount the injector on the wellhead.

Aside from mounting the injector, all operations to install and remove the tubing are controlled from a cabin on the truckbed; no personnel need to be on the drilling pad during tubing insertion and removal. Fluids circulated out of the well are controlled by a wellhead packoff or blowout preventer and by valving to direct the fluids to appropriate containers for disposal. The advantage of coiled tubing for P\&A activities is the minimal risk of exposure to personnel; the main disadvantage is that no drilling operations can be conducted.

Wireline equipment. The normal role of electric wireline equipment in the P\&A of WAG 10 wells will be to provide possible jet perforating services. 
Cementing equipment. Cementing equipment will include a storage unit, blending and mixing unit, measuring and monitoring equipment, and a pumping unit. Typically, the cementing equipment also provides the high-pressure pumping capability for conducting plug tests and casing leak tests.

P\&A tools. Applications of some of the specific tools to be employed in the P\&A of WAG 10 wells are described below. Examples of these tools as used in the oil and gas industry are given in BNI 1995c. These examples are only for illustrative purposes, and endorsement of tools and equipment from specific suppliers is not implied.

Packers. Packers will be used to pressure-test casing, isolate sections to be squeezed, and test the integrity of plugs. Packers consist of a steel mandrel furnished with an expandable element to seal against the casing or borehole; both mechanically set and inflatable packers are available. Mechanically set packers are expanded by rotating tubing or applying tubing weight or tension. Inflatable packers are set by applying pressure from the surface. Mechanically set packers typically must be set using standard rotary drilling and jointed pipe, and inflatable packers can be set on a jointed pipe or coiled tubing. Use of inflatable packers is recommended for P\&A of most WAG 10 wells because of the uncertain casing condition. Mechanically set packers, either permanent or retrievable, may be applicable in wells from which casing will be removed.

Perforator. Perforating tools can be used to perforate casings for placement of isolation plugs above or near the bottom of the injection horizon, where applicable, and below the shallow freshwater zone. Three types of perforators were investigated: mechanical, explosive jet, and hydraulic jet.

Mechanical perforators punch holes in tubing or casing but do not penetrate cement; therefore, they can be used only for perforating uncemented tubing or casing. Explosive jet perforators are based on shaped-charge technology; they are powerful enough to perforate several strings of casing and cement grout. Jet perforators are the most commonly used method of perforating casing for remedial cementing and will be appropriate for all WAG 10 wells with casing 22.5 -in. ID if the use of explosives is permitted. Hydraulic jet perforators employ a high-pressure jet of water laden with abrasive directed horizontally against the casing and grout. The hydraulic jet has a penetration range comparable to the explosive jet perforators but is slower and generates more waste.

Milling (windows). Milling windows through casing is an alternative to perforating for placement of isolation plugs in wells with inside diameters of 4.2 in. or wells from which smaller inner casing has been removed. A window is cut in the casing using a section mill, an expandable drilling bit with tungsten carbide, or other hard-alloy cutting surface. An expandable drilling bit, called an underreamer, is then used to drill out cement in the window.

Mills (casing). These tools, commonly called "junk mills," function by literally shredding the casing or any other extraneous metal in the well. They are available in a variety of styles according to their application. Skirted mills and pilot mills are intended for use where it is critical that the mill follow the original hole exactly.

Washover tools. Washover tools include a casing, rotary shoe, and pipe cutter. The washover casing is furnished with threaded connections specifically designed to withstand the rigors of drilling. The rotary shoe, or washover shoe, is a drilling bit with an inner diameter large enough to fill the well casing or tubing; it usually has tungsten carbide cutting surfaces. Pipe cutters are used to sever the casing or tubing being washed over when necessary to remove a section. 
Plugging and sealing materials. There are literally humdreds of different cement formulations available that could be applicable to P\&A of WAG 10 wells. (Cement in this context means portland cement; chemical grouts are not considered for use in plugging and abandoning WAG 10 wells.) While several different formulations will probably be used during the P\&A program, only two basic cement types are considered here. All other possible formulations are variations of these two types, including the use of various additives to increase or decrease slurry weight, or to retard or accelerate setting time.

(1) Class A [American Society for Testing and Materials (ASTM) Type 1] portland cement with $2 \%$ bentonite and $4 \%$ calcium chloride, mixed with 6.3 gal of water per standard sack of cement. The bentonite decreases slurry density, and the calcium chloride accelerates setting time. This cement has a relatively low slurry weight $(14.7 \mathrm{lb} / \mathrm{gal})$ and sets to a compressive strength greater than $500 \mathrm{psi}$ at the WAG 10 ambient groundwater temperature $\left(60-65^{\circ} \mathrm{F}\right)$ in approximately $12 \mathrm{~h}$. Variations of this formulation will change the setting time and the slurry weight. The latter will be a consideration with respect to exceeding fracture pressure when plugging the deepest wells.

(2) "Micro fine" cements. These cements are also basically portland cement, with additives to yield specific properties in the fluid and set cement. They differ from Class A portland cement by having a particle size about one-tenth that of standard cement. Because of this characteristic, they can penetrate leakage pathways too small to be effectively plugged by standard cement. Micro fine cement will be used in the WAG 10 wells for placing isolation plugs through casing perforations/windows. BNI 1995c includes a technical paper describing micro fine cement and its physical properties and applications.

Site Preparation. Site preparation will include removal of any structures that obstruct access to the wellhead, stabilization of the site to support the weight of P\&A contractors' equipment and support vehicles, and possibly construction of access roads. P\&A operations will require a reasonably level, clear area of about $100-\mathrm{ft}$ radius around the wellhead. Within this area, a 60 - by $100-\mathrm{ft}$ compacted gravel pad, capable of supporting a multi-axle truck and trailer weighing approximately $80,000 \mathrm{lb}$, will be constructed. Any overhead power lines within $100 \mathrm{ft}$ of the wellhead will be removed or relocated, and aboveground and underground utilities will be marked or relocated.

It is assumed that the site preparations will be done by an ORNL site contractor before mobilization of the P\&A contractor's equipment to the site. The P\&A contractor will inspect each site before mobilizing equipment.

Preparation of wellhead. If the existing surface is unstable, or if there is no surface casing, preparation may also include installation of conductor casing to provide positive containment of fluids and solids produced during P\&A operations. If needed, a conductor casing will be installed by driving a steel casing over the existing casing or tubing to refusal using a pile driver or similar piece of equipment. Surface flow control equipment connections will be made to this casing, and a reinforced drilling pad will be installed around the surface casing.

Well evacuation and static equilibrium. Standing fluid in the well casings will be replaced with uncontaminated fluid before any other downhole operations are begun. The standing fluid will be displaced to reduce the potential for exposure of personnel and equipment to contaminants during subsequent operations. Also, both state (TDEC 1200-4-6-09) and federal [40 CFR 146.10(C)] regulations require that wells be in a state of static equilibrium before P\&A. (Static equilibrium means that there is no flow within or out of the wellbore.) These requirements will be met by displacing the standing fluid with uncontaminated fluid whose density has been adjusted to provide a slightly overbalanced condition with respect to static equilibrium; that is, the fluid level in the well after this operation will be 5 to $10 \mathrm{ft}$ below the surface. 
The displacing fluid will be saltwater, made by mixing sodium chloride with potable water to a specific gravity of 1.027 to 1.030 . Standing water will be displaced from the bottom upward, using small-diameter tubing set at the bottom of the well. The size of the tubing and method of setting the tubing in each well will be dictated by the inside diameter of the inner casing.

Standard jointed (threaded) tubing can be used only in wells having an inner casing with an ID of $\geq 2$ in. This type of tubing can be set and removed by a rotary drilling rig of the type used for well construction and workover. A coiled tubing unit will be used to set tubing in wells with $\mathrm{ID} \leq 2$ in. Approximately two well volumes will be circulated out of each well. It is assumed that the fluid removed from the wells will need to be treated as low-level radioactive waste, and the standing water removed from some of the wells is expected to contain elevated levels of nitrate and TDS.

Fracture gradient and pressure. Placing relatively dense (14.1 to $15.6 \mathrm{lb} / \mathrm{gal})$ cement slurries and applying pressure to squeeze cement into subsurface voids will subject the formations to greater than hydrostatic pressures. A specific design criterion for the P\&A procedures is avoidance of pressures that could initiate new fractures or extend old ones in these strata.

The pressures at which the formations underlying WAG 10 would fracture are unknown. In the absence of actual data, fracture pressure may be estimated from an assumed fracture gradient, commonly $1 \mathrm{psi} / \mathrm{ft}$. An allowable hydrostatic pressure gradient of $0.7 \mathrm{psi} / \mathrm{ft}$ was used to provide an adequate factor of safety. This means that for a $1000-\mathrm{ft}$ well, the maximum bottom hole pressure allowable would be $700 \mathrm{psi}$. This pressure limitation is the sum of the hydrostatic pressure and applied squeeze pressure.

Balanced cement plug. Tennessee UIC rules [TDEC 1200-4-6-.09(7)(b)] require that cement grout or other sealing materials "be introduced at the bottom of the well or interval to be sealed and placed progressively upward to the top of the well." The "balanced plug" method complies with this requirement.

In the balanced plug method, a volume of cement calculated (plus $15 \%$ allowance) to yield a plug of the desired height is introduced through tubing set near the bottom of the interval to be plugged. After the required volume of cement has been placed, water is pumped into the tubing to displace the cement in the tubing to the depth of the top of the intended plug. The result is a balanced cement column, which means the top of the cement inside the tubing is near the same level as the cement outside the tubing. The tubing is then pulled up out of the cement and flushed with more water. The wellhead is shut-in, squeeze pressure is applied, and the cement is allowed to set. After the cement has set long enough to develop sufficient compressive strength (about $500 \mathrm{psi}$ ), depth to the top of cement is confirmed by "tagging" with the tubing.

Pressure testing casing. The bradenhead squeeze is the most expeditious method for conducting squeeze cementing operations for P\&A of most WAG 10 wells. In this method the cement grout is placed in the interval to be plugged, and the cementing tubing is pulled up out of the cement. The annulus between the tubing and well casing is then sealed ("packed off"), and pressure is applied to squeeze the cement into any voids around the casing shoe, or behind the well casing in the case of squeezing through perforations/milled windows. The bradenhead squeeze method requires that the casing be reasonably watertight (for squeezing across the casing shoe) or that the only fluid exit be via intentionally made perforations/windows.

Therefore, all well casings (except for the 1.25-in.-ID wells) will be pressure-tested for watertightness before cement placement begins. During initial well evacuation, casings in wells with no open hole can be tested by sealing between tubing and casing, applying pressure, and observing 
pressure bleedoff. For wells with an open hole, it will be necessary to seal off the openhole using a removable packer. Pressure tests will be conducted at a test pressure of approximately 100 psi (surface gauge pressure) for $1 \mathrm{~h}$. A well will be considered watertight for the purpose of applying the bradenhead squeeze method if pressure bleedoff does not exceed 5 percent of the test pressure. Squeeze cementing of specific intervals will require using packers to isolate the interval in wells that are not watertight and in wells that are uncased through the shallow freshwater zone.

Cement plug placement methods. All cement plug placement methods provide for the filling of all or part of the openhole interval (if any) and all of the well casing to be left in the well. At specific intervals, placement of cement will include applying and holding pressure on the fluid cement slurry to ensure a good seal with the formation and plugging of channels. The plugs will be placed over competent, low-permeability intervals. The application of pressure, over and above the hydrostatic pressure of the fluid cement column, is called squeezing cement or pressure grouting.

In high-pressure squeeze cementing, the applied pressure is sufficient to break down (fracture) the formation and emplace cement into the fractures. In low-pressure cementing, the applied pressure is kept below the fracture pressure; cement moves into pre-existing voids and flow channels but does not initiate new fractures or enlarge old ones. Only low-pressure squeeze cementing will be used in the WAG 10 wells.

In general, cement will be placed in the openhole and squeezed across the bottom of the casing (the casing shoe). Wells having EMI will then be filled with cement to within $5 \mathrm{ft}$ of the surface. In wells that do not have EMI, isolation plugs will be placed through casing perforations at specific intervals, or well casings will be removed before the wellbore is filled with cement. The casing between isolation plugs will be filled with cement, and squeeze pressure will be applied if needed to seal casing leaks. The exact depths of plugs and intervals to be squeezed and method of cement placement will vary depending on well conditions. Cement placement methods and the conditions under which they will be used are described below.

Staged cementing. This P\&A method will be used for wells that have EMI and possibly in some wells that are of uncertain integrity. Staged cementing will be conducted as follows.

1. Set jointed tubing (rotary drilling equipment) or coiled tubing 2 to $5 \mathrm{ft}$ above the bottom of the well casing. Pressure test casing to approximately $100 \mathrm{psi}$ for $1 \mathrm{~h}$.

2. If the casing is watertight, remove the packer, reset tubing, and place a balanced cement plug from the bottom of the well up to 50 to $75 \mathrm{ft}$ above the bottom of the well casing. Pull tubing above cement. (Note: The actual depth of the plug may vary depending on well and casing depth and cement slurry density; these will be calculated by the P\&A contractor for each well.)

3. Apply squeeze pressure not to exceed the nominal fracture pressure. Hold pressure until cement has set. (Note: A bradenhead squeeze will be used if the casing is watertight. If it is not, a mechanical or inflatable packer must be used to conduct this operation.)

4. Place cement to within $5 \mathrm{ft}$ of the ground surface in one or more stages as required by fracture pressure considerations. Squeezing is required to emplace cement through any leaks in casing. (Note: As mentioned in Sect. 6.2.1, isolation plugs may be an option for wells with leaky casing intervals.)

5. Cut off casing below grade, and weld identification plate on casing. 
Cementing through perforations. This method will be used for plugging and abandoning wells that do not have EMI and that have an inner-casing diameter 22.5 -in. $\mathrm{ID}$. The casing diameter limitation is based on the smallest casing size that will accommodate a perforating tool large enough to reliably penetrate casing, cement sheath, and into the formation. Cement isolation plugs above and near the base of the injection horizon and below the bottom of the shallow freshwater zone will be placed in accordance with the general P\&A plan.

This method differs from the staged cementing procedure described above in that the plugs are placed by squeezing cement through perforations in the casing. P\&A by this method will proceed generally as follows.

1. Evacuate standing fluid and stabilize the well.

2. Pressure-test the well casing.

3. In wells having an openhole interval, place a balanced cement plug in the open hole up to 50 to $75 \mathrm{ft}$ above the casing shoe. Apply squeeze pressure and hold until cement has set. (Note: If well casing is not watertight, an inflatable or mechanical packer will be required for squeezing.)

4. Continue cementing to the depth at which the lowermost isolation plug is to be set. This may be at the bottom of the lower Pumpkin Valley Shale, at the bottom of the Rutledge Limestone, and/or at the top of the lower Maryville Limestone, depending on well and casing depth.

5. Perforate the casing over the interval in which the isolation plug is to be set.

6. Place cement from the top of the preceding cement stage, across the perforated interval, and up to about $30 \mathrm{ft}$ above the highest perforation. Use matrix-penetrating cement.

7. Withdraw tubing above cement, pack off between tubing and annulus, and apply squeeze pressure to force cement through perforations and into the well annulus. Hold pressure until cement has set.

8. Verify plug placement and pressure-test plug and casing.

9. If a second or third isolation plug is needed, repeat steps 5 through 9. Then place cement to within $5 \mathrm{ft}$ of the surface, cut off casing, and weld identification plate on casing.

Cementing through windows milled in casing. This procedure is generally analogous to placing isolation plugs by squeezing cement through perforations, except that the casing is breached by milling a section of the casing opposite the interval in which the plug is to be placed. The remaining cement in the window is then removed by underreaming into the native formation.

This method provides a higher level of assurance that an effective isolation plug has been placed as intended. The method is more expensive than perforating and is applicable only for wells having an inside diameter of 4 in. or larger. It also generates more waste than the perforate and squeeze method. This procedure was not selected as the primary procedure for P\&A of any WAG 10 well. It is considered, however, a potentially applicable alternative procedure for some wells.

Verification of plug placement. Placement depth and integrity of cement plugs will be verified by tagging the cement with tubing and conducting a pressure test. Both operations will be performed after the cement has reached a compressive strength sufficient to allow the tests to be performed.

The criterion for time before testing will be the theoretical time for the cement to reach a compressive strength of $500 \mathrm{psi}$. Setting times are controlled by cement composition and temperature; cementing service companies provide tables giving time to reach specified compressive strengths. 
Typical setting times are 8 to $12 \mathrm{~h}$, but times up to $24 \mathrm{~h}$ may be specified for some formulations. The relatively low temperature $\left(60^{\circ}\right.$ to $\left.65^{\circ} \mathrm{F}\right)$ in the WAG 10 wells will slow the setting process.

A cement plug is tagged by lowering tubing, usually the tubing used to place the cement, until it contacts the top of the plug, as evident by a drop in weight shown on the indicator. A weight of 1,000 to $3,000 \mathrm{lb}$ will be applied to the plug to verify that the tubing has contacted solid cement.

The plug will be pressure-tested using the bradenhead method, provided the casing above the plug is watertight. If the casing is not watertight, a packer will be set above the plug to conduct the test.

\subsubsection{Casing Removal Methods}

Casing washover. Casing washover involves overdrilling the well casing with a casing of larger diameter (wash pipe). The wash pipe is equipped with a bit (termed a rotary shoe) designed to drill out the cement between the inner casing and outer casing, or between casing and formation. Sections of the casing are severed and removed as the washover progresses. After the casing is removed and remaining grout is drilled out, the well is plugged by the staged cementing method. The depth of washover is well-specific. If the washover removal is to proceed only to the depth at which the lowermost isolation plug is to be set, the casing and openhole below that depth will be cemented using the balanced plug method. The lower part of the well below the washover depth will be plugged before washover begins.

This method requires use of a rotary drilling rig with mud circulation and thus generates a relatively large amount of waste, in addition to the removed casing. The washover method involves some risk that drilling may deviate from the course of the original drilled hole and that re-entering the original hole to complete P\&A may be impossible. The possibility of this occurring is increased because WAG 10 wells deviate from the vertical and some of the inner casings are in poor or unknown condition. However, this is a fairly common and recognized procedure, and the risks are considered manageable at the relatively shallow depths of the WAG 10 wells. Washover operations extending below the Rutledge Limestone are not recommended.

Casing milling. Milling out casing is generally analogous to the washover method, except that the inner casing is removed by drilling it out (milling) using a metal-cutting bit (the mill). The casing is removed as metal chips and shavings rather than as intact sections. Milling is generally faster, and therefore, less expensive than washing over casing. The risk of exiting the original borehole is somewhat greater when compared with washover, but specialized milling bits (e.g., skirted mills, pilot mills) are available to reduce the likelihood of this occurring.

Milling provides about the same level of assurance of effective isolation as washover and is applicable to all diameters of wells. Washover is preferred over milling out casing because of the lesser inherent risk of exiting the wellbore. These are the only methods that can be used, other than staged cementing in place, for P\&A of wells with inside diameters of less than 2.5 in. The method provides a high level of assurance that effective isolation has been achieved but is expensive and not without risk. 


\subsection{WASTE MANAGEMENT}

Before well closure activities begin, an ORNL/ER waste management checklist would be generated to identify all waste-generating activities and define the steps to be taken to manage and characterize those wastes properly. This checklist would be reviewed and approved by the appropriate ORNL/ER project and WM officials (Clark et al. 1995). This section discusses some of the waste management considerations that would be further developed in the waste management checklist.

\subsubsection{Waste Types}

P\&A of the WAG 10 NHF wells will generate a variety of solid and liquid wastes in types and quantities dependent on the approach selected. The major categories of wastes generated from the well P\&A operations are as follows.

- Liquids. The standing columns of water in the wells were sampled and analyzed during the field effort. The water is primarily brine (TDS $\geq 100,000 \mathrm{mg} / \mathrm{L}$ ) and contains various levels of radiological contamination (maximum gross beta $32 \mu \mathrm{Ci} / \mathrm{L}$, total gamma $14.3 \mu \mathrm{Ci} / \mathrm{L}$, and ${ }^{90} \mathrm{Sr}$ $20.4 \mu \mathrm{Ci} / \mathrm{L}$ ). The standing water will be displaced to the surface with make-up saltwater.

- Solids

- Formation and cement solids. These solids are generated primarily during removal or window underreaming operations; some may also be generated during clear out of the wellbore prior to cementing. The solids are carried out of the wellbore by the drilling fluid and may vary in size from silver dollar-sized chunks to particles as small as 1 micron (TWO 1987). Included with the formation and cement solids are any drilling fluid additives.

- Metal cuttings. If the well casings are milled out during removal or forming a window, metal cuttings in the form of fine particles or slivers/ribbons will be generated. They will be mixed with the formation and cement solids.

- Surface reclamation solids. These solids include cement pads and guardposts or rails around the wellheads, the wellheads themselves, and soil that is excavated to terminate the well casing $5 \mathrm{ft}$ bgs.

- Pipe (casing or tubing), drilling tools, and other downhole equipment. Various lengths and sizes of tubing or casing will be cut and pulled out of the wells during washover operations. Downhole equipment and drilling tools that become worn out or cannot be decontaminated to free release limits will also need to be disposed of.

- Noncompactible solids. These wastes include pipe, lumber, metals, concrete, and glass.

- Compactible wastes. Examples include disposable personal protective equipment (PPE) (e.g., gloves, Tyvek suits, respirator cartridges, and booties), trash, rags, and cans.

- Slurries and sludges

- Displacement fluid. Saltwater is inserted to maintain static conditions in the borehole and displace cement from tubing during placement of balanced cement plugs.

- Drilling fluid (mud). Drilling fluids consist of fresh or saltwater mixed with bentonite or other additives. The drilling fluid lubricates and cools the downhole tools, carries the cuttings up from the bottom, and prevents blowouts and cave-ins by stabilizing friable or porous formations and maintaining static conditions in the borehole. 
- Decontamination fluids. Washing and decontaminating the downhole equipment, rig, and other components will generate additional quantities of radiologically contaminated solid and liquid waste. Sampling and drilling tools are subjected to initial gross decontamination within the AOC before they are transported to the central decontamination and cleaning facility. Small volumes of deionized water and hand wipes are used to remove gross contamination in the field before tools are transported to the decontamination facility.

- Spent abrasives. Hydraulic jet perforators employ a high-pressure jet of carrier fluid (e.g., water) with an abrasive (e.g., sand) to penetrate casing and grout.

\subsubsection{Waste Quantities}

Table 6.4 estimates the waste quantities generated from the proposed P\&A methods. To obtain conservative estimates, it was assumed that liquid rather than air will be used as a drilling fluid. Waste types for which quantities have been estimated include standing water and displacement fluid. Waste types not included in the table are surface reclamation solids, spent abrasives, decontamination fluids, and compactible/noncompactible wastes.

The summed NHF waste quantity estimated for standing well water is $3,500 \mathrm{ft}^{3}$ (26,200 gal); for displacement fluid, it is $2,900 \mathrm{ft}^{3}(21,700 \mathrm{gal})$. The waste estimates in Table 6.4 assume all the wells will be plugged throughout their length except for Well 1971. It is recommended that the top $250 \mathrm{ft}$ of casing and grout be cut and removed from NHF Well 1971. This will result in $1,500 \mathrm{ft}^{3}$ of drilling fluid and 250 linear $\mathrm{ft}$ of well casing.

\subsubsection{Waste Determination}

As mentioned in Sect. 5.2, wastes generated during P\&A of the WAG 10 wells may be considered IDW if the action is determined to be a CERCLA response. IDW may include contaminated PPE, drilling mud, cuttings, and purge water. The IDW may be left at the same CERCLA AOC at which it is generated [under the provisions of the EPA IDW guidance (EPA 1992), wastes generated within a specific AOC may be managed within that area until final remedial action]. A waste consolidation area could be located within the WAG 5 AOC for managing and storing WAG $10 \mathrm{IDW}$ until (and their disposition will be consistent with) the final remedial action of WAG 5. A waste staging area will be established within WAG 5 to permit the segregation and efficient consolidation of IDW and non-IDW generated during WAG 10 activities. While the consolidation area is being prepared, the staging area will be used for temporary retention of IDW intended for disposition within the consolidation area in a controlled and protective manner. NonIDW will be maintained within the staging area until transferred to Energy Systems for disposal.

P\&A wastes that cannot be classed or managed as IDW will be managed under existing procedures by the Energy Systems/ORNL organizations responsible for radioactive and hazardous waste disposal. These wastes may include

- CSL operations wastes,

- field instrument maintenance and standardization wastes,

- motor-driven equipment wastes, and

- decontamination and cleaning facility operations wastes.

Mechanisms and procedures are in place for managing these wastes. 
If the wastes generated are not under the CERCLA umbrella, the IDW management options are not available and the wastes will need to be handled or processed for final disposition. The ORNL Radioactive Solid Waste Group supervisor is to be consulted on the availability of disposal and storage space for solid radioactive waste; likewise, the ORNL Liquid Gaseous Waste Group supervisor is to be consulted regarding disposing of liquid waste that may be generated. Slurry or sludge waste (such as some drilling muds) is not normally managed by the ORNL Radioactive Solid Waste Group or the ORNL Liquid Gaseous Waste Group unless it has been dewatered. A written contingency plan is required to be in place for slurry/sludge waste to address how it will be placed in a form that can be accepted by ORNL Waste Operations (Clark et al. 1995).

Criteria for appropriate screening and classification of wastes for cost-effective disposition or isolation will be consistent with the EPA guidance (EPA 1992) for IDW and with currently available, applicable regulatory or administrative guidelines. Data such as CSL screening data for transportation or sample selection will be used as needed. If process knowledge of waste content is sufficient for classification and is adequately documented and recorded as part of the waste management records, laboratory testing will not be performed.

Wastes will be classified by the Waste Generation Certification Officer with assistance as necessary from the ES\&H manager, the project health physicist, and/or the project industrial hygienist. If necessary, the ORNL Field Coordination Manager will be contacted to determine the disposition of waste solids. Criteria are developed in accordance with the guidance in Articles 131 and 132 of DOE 5480.6, Radiological Control Manual (DOE 1992).

\subsubsection{Waste Minimization}

Because waste materials (e.g., PPE, damaged machine parts, soil, water, and sludge) generated during P\&A have the potential to be contaminated with hazardous substances, they will be treated as contaminated waste until survey or monitoring results establish that they can be released from the site. This section discusses the technical approach and the field methods and planning necessary for minimizing wastes.

Technical approach. Waste minimization will be among the criteria included in selecting the appropriate P\&A technologies. For instance, drilling techniques can affect the volumes and types of waste generated. P\&A techniques considered include wet and dry rotary methods of washover or overdrilling. Wet washover, or rotary wash, will generate substantial quantities of liquid waste in the form of slurries that contain drilling mud, rock, dirt, casing fragments, and incidental formation water. Because no drilling fluids are used with air rotary drilling, liquid wastes generated by this technique would consist of incidental water added for lubrication and encountered in the formation(s).

Material selection. Materials (e.g., equipment) will be able to withstand continuous field use and be easily decontaminated. Because of its ability to be effectively cleaned, stainless steel will be used for equipment that will come in direct contact with potentially contaminated environmental media. High-carbon steels will be used for tasks that require greater ductility.

Drums, boxes, and tanks will be used to contain wastes as they are generated. Ground coverings (such as synthetic geotextiles or plastic material) may be used for temporary accumulation of potentially contaminated materials until release surveys can be conducted. The coverings and containers will be located near the field activity inside the controlled access area (CAA), and the wastes will be tentatively segregated into identified waste. 
PPE selection. Field personnel wear PPE to prevent potentially radioactive and hazardous materials from contacting the skin and entering the body. The basic set of PPE (Level 1) required in the field includes washable cotton coveralls and disposable gloves. Activities that can expose personnel to higher levels of contaminants will require additional sets of clothing and gloves. Protective equipment will be chosen to minimize the amount of waste material generated and to enable recycling of as much PPE as possible.

Contamination control. Areas that may contain elevated levels of hazardous contaminants will be controlled to minimize the potential for spread of contaminants. Ropes, barricades, and signs will control access to these areas, and individuals will be monitored before they leave CAAs. Materials will tentatively be segregated within the WAG 5 boundary as clean or contaminated, and field decontamination will reduce the amount of waste to be disposed of.

Material minimization. Equipment and personnel entry into CAAs will be restricted to reduce waste. All packaging will be removed from materials before they enter potentially contaminated areas, and the size of field crews will be maintained at levels that allow the activity to be performed safely.

Decontamination. Materials that come in contact with potentially contaminated substances must be monitored and, if contaminated, must be decontaminated by nonaggressive (dry wiping) to aggressive (grit blasting) techniques. Wiping is preferred because it is efficient and minimizes waste generation; more aggressive cleaning creates additional solid and liquid waste and can weaken the structure of the equipment so that it becomes waste.

\subsubsection{Waste Handling and Disposition}

Wastes will be checked for radioactivity and organic vapors. A containment system (e.g., plastic coverings) that restricts the release of the wastes to the environment may be provided for all waste materials (radioactive, chemically hazardous, and environmentally controlled as well as nonhazardous) throughout P\&A operations.

Options for handling and disposition are based on waste forms and classifications. Non-IDW wastes will be handled and dispositioned in accordance with existing procedures. IDW, if relevant and as appropriate, will be dispositioned within the WAG 5 AOC until final remedial action. Some waste materials from both categories may be transferred to Energy Systems Waste Operations for disposal.

Liquids. Waste liquids will be packaged in the field in containers compatible with the anticipated characteristics of the liquids collected and sampled/analyzed for contaminants. All liquids that do not exceed the WAC of the ORNL liquid waste treatment plants will be sent to the appropriate plant for disposal; liquids that do exceed those concentrations will be packaged in appropriate containers and stored at the waste staging area until a disposal option is determined by the Liquid Radioactive Waste Operations Supervisor, in accordance with internal Energy Systems procedures.

The approximate costs for treating liquids at the ORNL treatment plants are:

- 1.5 cents/gal for the NRWTP,

- 10 cents/gal for the PWTP, and

- 10 to 12 dollars/gal for the LLLW evaporator system. 
The LLLW evaporator system is not only the most expensive of the treatment plants by two orders of magnitude, but any liquids being considered for the system undergo close scrutiny with regard to WAC (i.e., detailed characterization is needed) and with regard to volume because the capacity of the LLLW storage tanks is limited.

Solids. Solids consist of waste materials from casing and grout removal and from surface reclamation activities. Wastes will be segregated using field instrument surveys (i.e., portable radiation and organic vapor survey instruments).

If labeled as IDW, it is expected that most of the solids will be maintained in the waste staging area in a manner consistent with the protection of human health and the environment and ultimately transferred to Energy Systems for disposal. If the waste is not IDW, it will be packaged and disposed of in accordance with internal Energy Systems procedures. Much of the waste should meet the WAC of the Interim Waste Management Facility in Solid Waste Storage Area (SWSA) 6. Waste Operations also has the option for the pipe of sending it to a contractor for smelting.

It is expected that some of the solids, such as soils excavated during surface reclamation, will be returned to their source of origination. The criterion for return of waste spoils is that the redisposition of spoils does not change aboveground radiation exposure rates from their presurvey rates measured $3 \mathrm{ft}$ above the ground surface.

Surplus solid wastes are those that could not be returned to the source of origination because of lack of space within the excavation site. Surplus solids with exposure rate $100 \mathrm{mrem} / \mathrm{h}$ will be transported to the consolidation area for disposal. Waste spoils that are deemed clean $\left(<1000 \mathrm{dpm} / 100 \mathrm{~cm}^{2}\right.$ beta-gamma) or show no detectable alpha contaminants by initial probe survey will be stockpiled on site (e.g., on top of a high-density polyethylene liner) for use as fill material for other activities. Spoils that exceed $100 \mathrm{mrem} / \mathrm{h}$ will be containerized, analyzed, and transferred to Energy Systems Waste Operations.

Sample residuals (e.g., soils, sediments, rock) that are not consumed by the analytical laboratory will be transferred to Energy Systems Waste Operations for disposal when they are no longer needed.

Compactible solids. Compactible solids such as contaminated PPE, wipes, and small containers that do not meet the criteria for release for unrestricted use will be collected in labeled polyethylene bags at the point of generation. These bags will be placed in appropriately marked containers and temporarily retained at the AOC.

Plastic sheeting and sleeving used in field operations to prevent contact of contaminated surfaces and soils with machinery and tools that are difficult to decontaminate will be handled as compactible waste and transferred to Energy Systems Waste Operations for disposal.

Noncompactible solids. Those noncompactible solid wastes that cannot be decontaminated will be retained within the AOC. Materials that do not exceed release limits will be released from the site.

Slurries or sludges. Sludges from P\&A operations, if not considered IDW, will be phaseseparated so that each component can be treated as a separate waste form (i.e., classified as solids or liquids). Separation can be achieved through settling and decanting/skimming, bulk filtration, centrifugation, or incineration. Settling and decanting/skimming is often the least costly.

TWO approach to drilling fluids. In evaluating WM approaches for non-IDW, it is instructive to revisit the conservative WM approach outlined by TWO (1987) to handle radioactive drilling 
fluids. In TWO's approach, the fluids from the wells would be diverted to a transportable solids control system at the rig site and then transported to a waste treatment system at NHF. These systems were developed to a conceptual-level design but never constructed.

The purpose of having the solids control system at the rig site would be to perform some liquidsolid separation and drilling fluids adjustment. Drill cuttings and solids would be mechanically separated from the drilling fluids into a paste-like waste (50 to $85 \%$ moisture), placed in polyethylene containers, sampled, and then transported to NHF for treatment and staging. Contaminated fluids would be transported to NHF for further treatment. The solids control system would consist of equipment and mixing vessels housed in three enclosed buildings, linked through sealed doorways. The semiautomated system would leave critical controls and monitors accessible to the driller. Primary waste processing equipment in the solids control system would include pumps, parallel shale shakers, mud-cleaning screens, auger conveyors, a centrifuge unit, cone desanders, cone desilters, and various tanks.

The purpose of having the proposed waste treatment system at NHF was to solidify and properly package the solids for storage and to render a portion of the waste liquids suitable either for reuse or permitted stream discharge. Liquids that could not be stream-discharged or reused would be sent to the ORNL LLLW system. The waste treatment system was to be composed of two identical enclosed units: one for treatment of radioactive and the other for treatment of nonradioactive waste. Both units were to have the capabilities for solids removal, solids solidification, desalination, and deionization. Solids solidification was to be performed with a blend of 3:1 cement (or quick lime):fly ash. Primary waste treatment equipment would include pumps, an enclosed pressure leaf filter, tanks and hoppers for chemicals addition, cartridge filter units, reverse osmosis units, and various tanks and vessels.

According to TWO, the estimated cost of the purchased equipment for the solids control system was $\$ 676,550$ (1987 dollars). Using a 2.3 factor cost estimate for engineering, construction, wiring and installation gives a total capital cost of $\$ 1,600,000$ (1987 dollars). The estimated cost of the purchased equipment for the waste treatment system was $\$ 1,004,000$ (1987 dollars); using a 2.6 factor cost estimate gives a total capital cost of $\$ 2,600,000$ (1987 dollars). Combined, these two systems represented an investment of $\$ 4,200,000$ (1987 dollars). Specific operating costs for the WM aspects of the P\&A were not provided; however, TWO did indicate that over $70 \%$ of the project cost would be due to health physics and waste treatment activities, and project costs ranged from $\$ 0.8$ million to $\$ 1.2$ million for some of the high-priority observation wells.

The substantial capital budget for WM parallels the significant lead time that would be required to engineer, construct, and install the complex WM systems. Transit, decontamination, and setup times between well locations would also be increased with the solids control system.

Other approaches. Part of the motivation for the WM approach described by TWO was the significant quantities of radioactively contaminated waste generated by removal of contaminated wells to TD. For P\&A options less rigorous than removal to TD, WM options less rigorous and costly than self-contained separation and stabilization systems should be considered.

It is not uncommon in P\&A of oil and gas wells to use solids separation equipment for drilling fluids; however, the purpose of the solids separation has been to recycle or reuse the drilling fluids rather than to dewater the solids to such a degree that the solids meet a particular disposal WAC.

One of the simplest separation processes is to collect the drilling fluids in tanks and decant or siphon off the liquid. The liquid could be transported to one of the ORNL liquid waste treatment plants as described earlier for liquid disposition. Some turbidity may be allowed for liquids sent to 
the PWTP because of the separation processes in use there. The PWTP has a water softening operation followed by a filter press for dewatering sludges resulting from the water softening operation and produce a waste stream with 60 to $70 \%$ moisture. This waste stream must then undergo additional treatment (e.g., drying) to reduce the moisture to below the SWSA 6 moisture criterion of 30 percent (ORNL 1994).

Another separation process involves recycling drilling fluids through a mud pan to reduce the volume of waste. If significant levels of contamination are encountered, however, the process can be converted to a "once-through" method to preclude excessive contamination of return lines and pumps. In either case, the mud pan is constructed to allow solids to settle, thereby creating both sludge and liquid waste. The liquids could be sent to the ORNL liquid waste treatment plants and the solids would undergo additional treatment by an offsite contractor. Recycling of the drilling fluids could also use bulk filtration rather than sedimentation to remove the solids.

A system currently in use at the ORNL sewage treatment plant that could be potentially applicable to phase separation of drilling fluids is a decanting centrifuge followed by a rotary-indirect dryer. The contractor operating the system is WasteMaster; the cost is $\$ 2.65 /$ gal of slurry feed. The system is designed to take a slightly radioactive slurry at $98 \%$ moisture, concentrate it to 80 percent moisture with the decanting centrifuge, and then dry it to 10 percent moisture (no free liquids) with the dryer before disposal at SWSA 6. Decanting centrifuges have been used in oil fields for years to reclaim drilling mud. The system could be designed with the centrifuge unit either at the well site or at the remote site with the dryer. Depending on the radioactivity levels of the P\&A drilling fluids, the current system operating at the sewage treatment plant may need to be upgraded for remote operation and better effluent monitoring and control. The percent moisture of the dried material could be increased to 70 to $90 \%$ to minimize generation of small, radioactive, respirable-sized (dust) particles.

A more expensive though still technically feasible solution is incineration. SEG operates an incinerator for ORR waste. Drilling fluids could be sucked into the incinerator at an approximate cost of \$20/gal. It is important to note, however, that sufficient quantities of dry, active waste (DAW; e.g., wood, paper, or plastic) must be co-fed with the fluids. An administrative decision would need to be made as to whether this DAW would need to be provided by the generator or by ORNL Waste Operations, or whether the DAW could originate from anywhere on the ORR. The leftover solids could be packaged for storage at SWSA 6.

If casing is removed using air rather than liquid as the drilling fluid, the air exiting the well will need to be diverted to tanks or vessels that allow the separation of the liquids and solids from the air and that exhaust through HEPA filters. The liquids and solids remaining in the tanks or vessels should separate from each other relatively easily because no viscous drilling mud would retain the solids in suspension. 


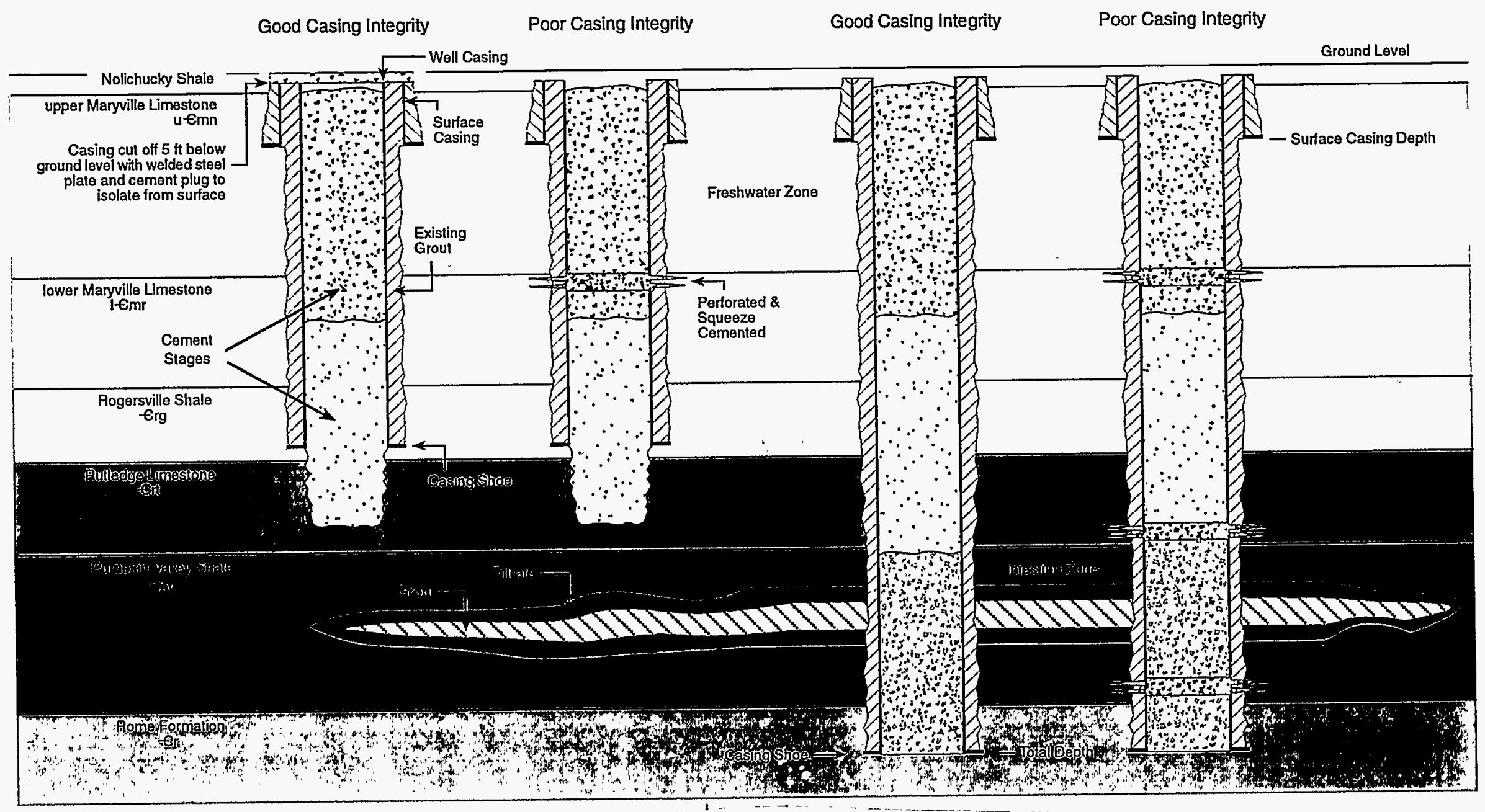

Fig. 6.1. Conceptual design of plugging options in rock cover and observation wells. 


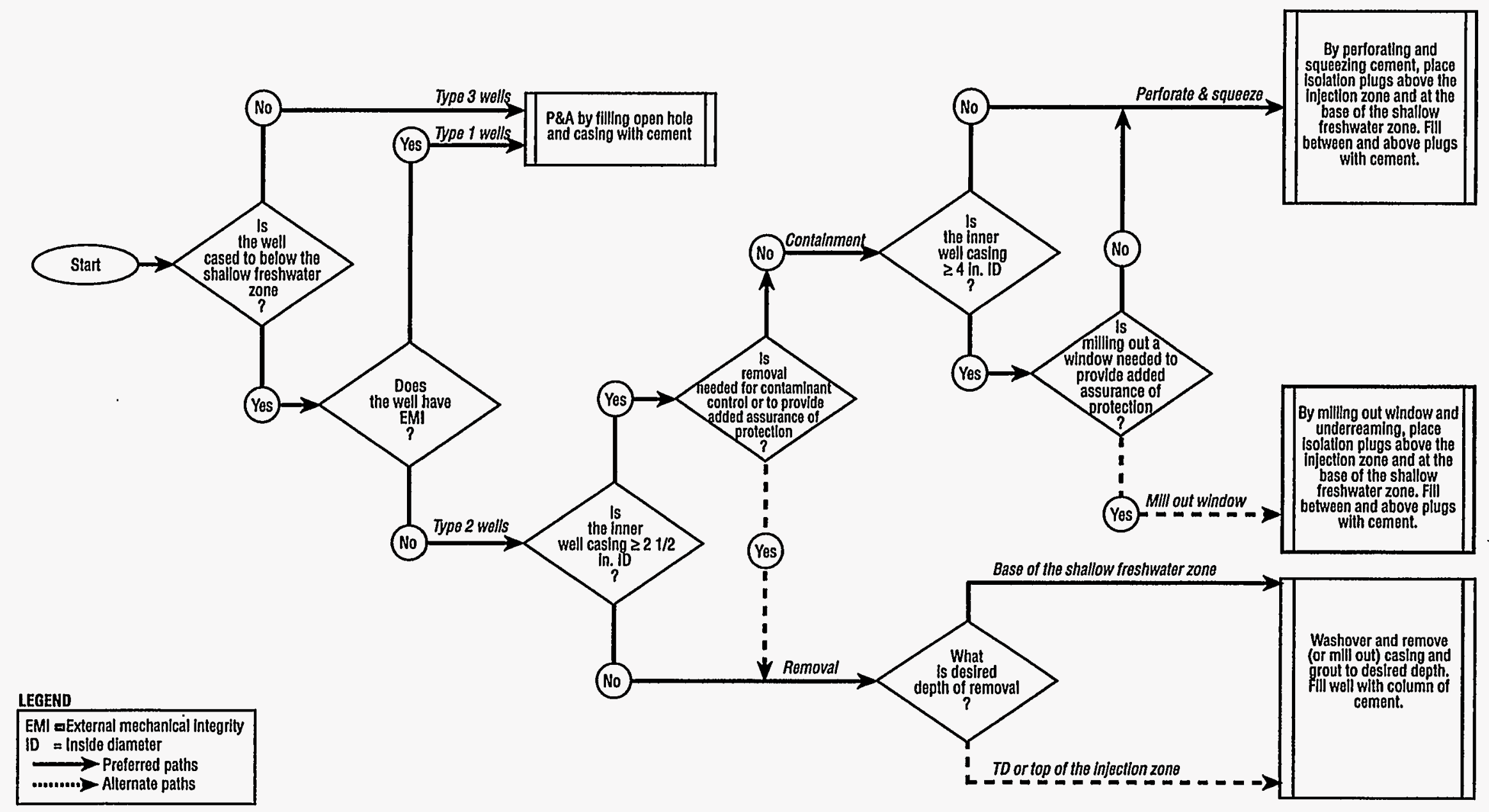

Fig. 6.2. Selection of plugging and abandonment method for WAG 10 wells. 


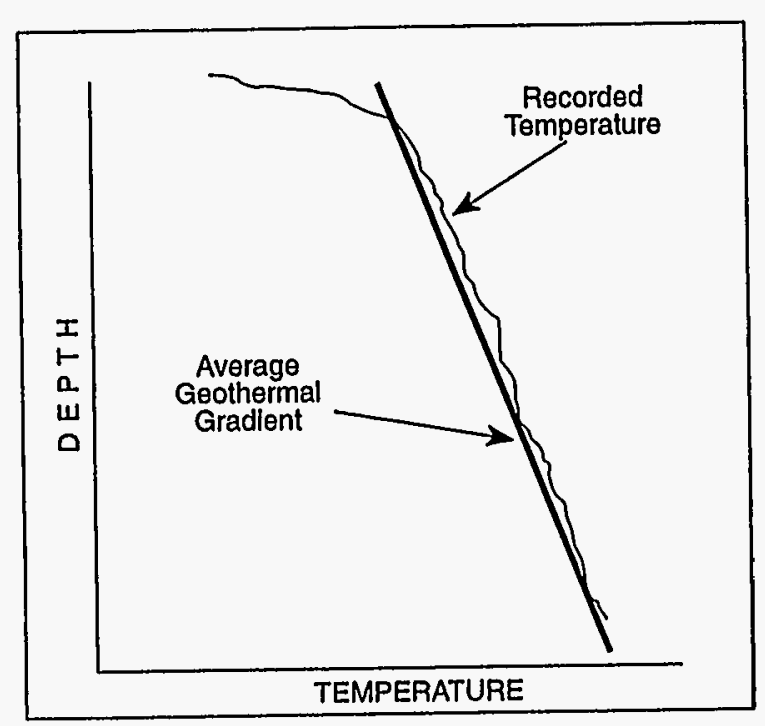

A. Hypothetical temperature log in which no BCWF has been detected.

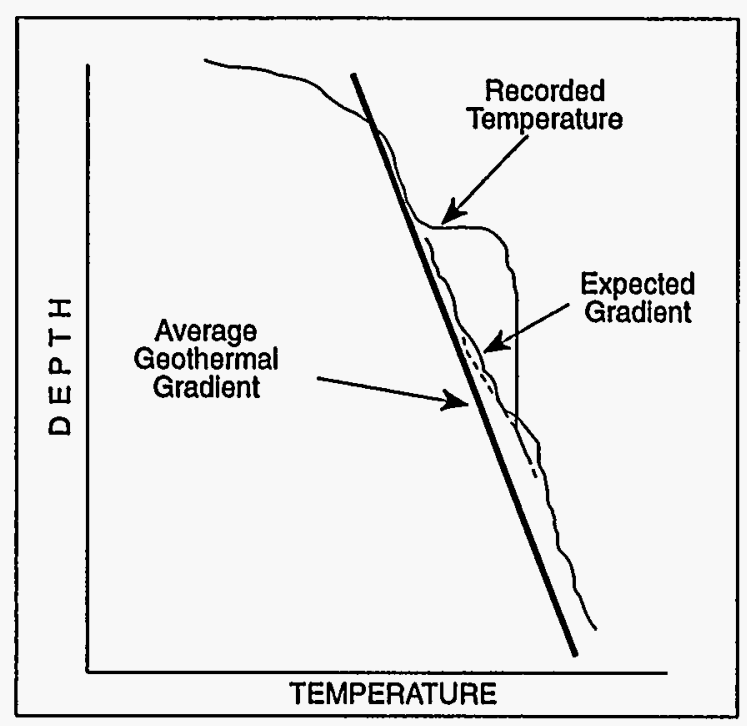

B. Hypothetical temperature log showing upward BCWF from saltwater to freshwater.

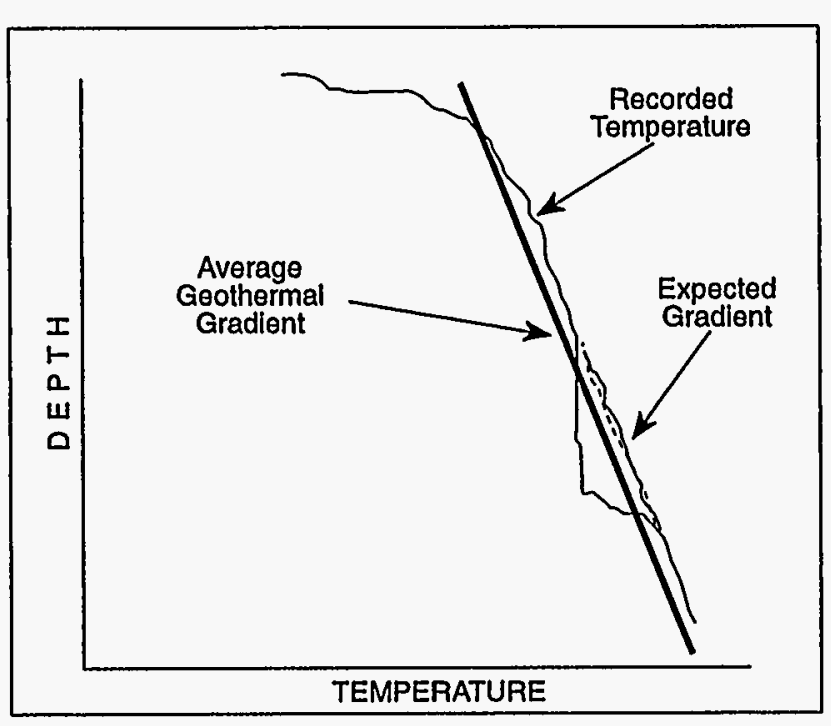

C. Hypothetical temperature log showing BCWF in a downward direction from freshwater to saltwater.

Fig. 6.3. Example hypothetical temperature logs under various behind-casing water flow conditions. 
Table 6.1 Response action screening summary

\begin{tabular}{|c|c|c|}
\hline \multirow{2}{*}{$\begin{array}{l}\text { Screening } \\
\text { criteria }\end{array}$} & \multicolumn{2}{|c|}{ General response actions } \\
\hline & Containment & Removal \\
\hline \multirow[t]{4}{*}{ Effectiveness } & $\begin{array}{l}\text { Meets minimum specified P\&A } \\
\text { requirements }\end{array}$ & $\begin{array}{l}\text { Exceeds minimum specified P\&A } \\
\text { requirements }\end{array}$ \\
\hline & Generates minimum amount of $P \& A$ waste & $\begin{array}{l}\text { Generates maximum amount of } \\
\text { waste }\end{array}$ \\
\hline & $\begin{array}{l}\text { Isolates critical groundwater intervals and } \\
\text { the injection zone but does not remove } \\
\text { casing or annular grout that may be } \\
\text { contaminated }\end{array}$ & Removes casing and grout \\
\hline & $\begin{array}{l}\text { Offers long-term protection of human } \\
\text { health and the environment and minimizes } \\
\text { risk of worker exposure }\end{array}$ & $\begin{array}{l}\text { Offers long-term protection of } \\
\text { human health and the environment } \\
\text { but contaminated waste quantities } \\
\text { brought to the surface increase the } \\
\text { risk of worker exposure }\end{array}$ \\
\hline \multirow[t]{3}{*}{ Implementation } & $\begin{array}{l}\text { Technically feasible for most wells; } \\
\text { however, P\&A tools are not generally } \\
\text { available for small- diameter casings } \\
(1.25 \text {-in. ID) }\end{array}$ & $\begin{array}{l}\text { Technically feasible, but deviations } \\
\text { from the borehole during milling or } \\
\text { washover can be costly and time- } \\
\text { consuming to correct }\end{array}$ \\
\hline & Administratively feasible & Administratively feasible \\
\hline & $\begin{array}{l}\text { Services and materials are available, except } \\
\text { for P\&A tools for small- diameter casings }\end{array}$ & $\begin{array}{l}\text { Services and materials are } \\
\text { available; however, the required } \\
\text { levels of expertise and } \\
\text { sophistication of equipment are } \\
\text { significant }\end{array}$ \\
\hline Cost & Low to medium & High \\
\hline Evaluation & $\begin{array}{l}\text { Retained; containment is considered to be } \\
\text { the better P\&A approach because of less } \\
\text { waste generation, lower worker exposure, } \\
\text { and lower cost }\end{array}$ & $\begin{array}{l}\text { Retained for special situations } \\
\text { where containment is difficult or } \\
\text { not feasible }\end{array}$ \\
\hline
\end{tabular}


Table 6.2. Comparison of plugging and abandonment methods

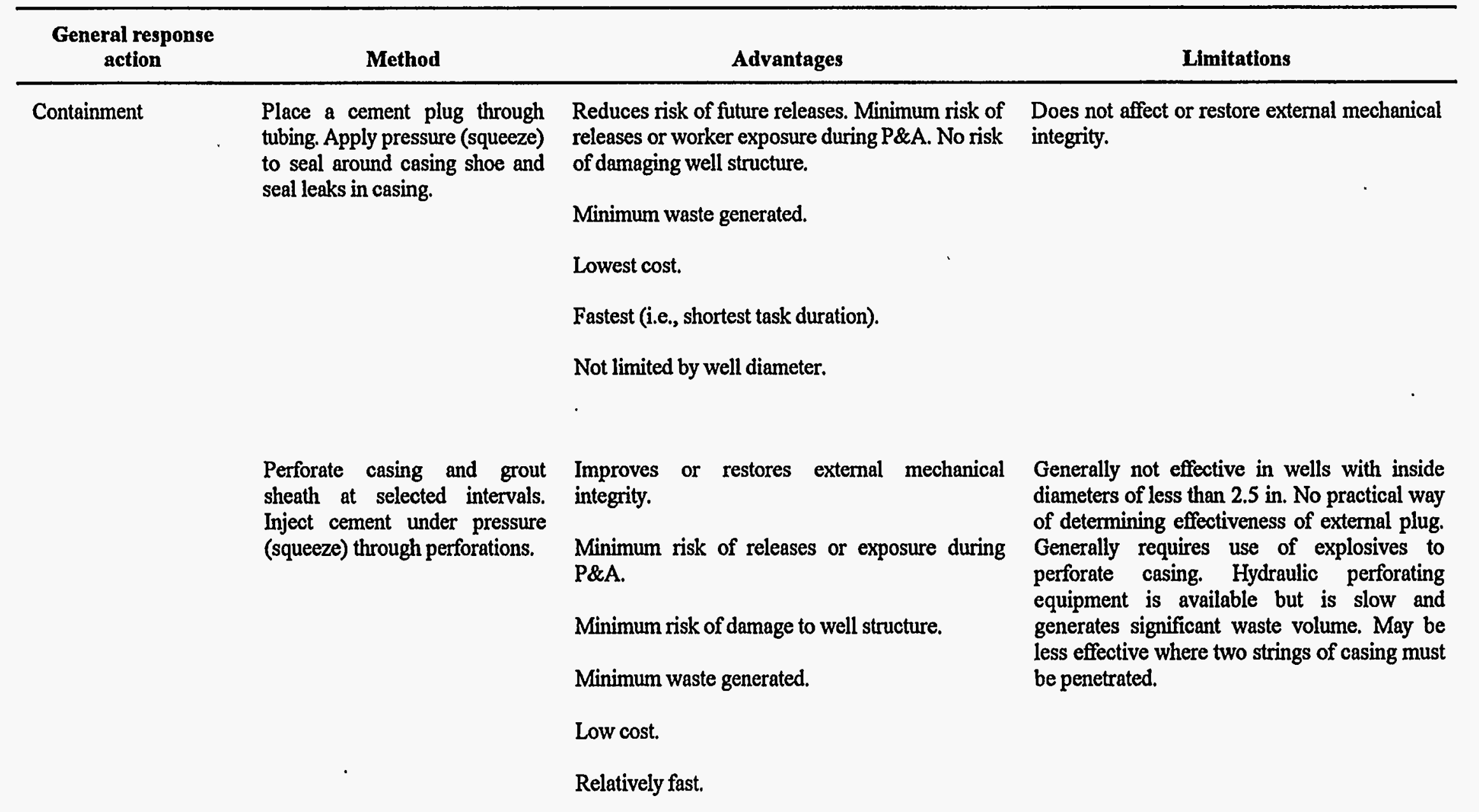


Table 6.2. Comparison of plugging and abandonment methods (continued)

\begin{tabular}{llll}
\hline $\begin{array}{c}\text { General response } \\
\text { action }\end{array}$ & \multicolumn{1}{c}{ Method } & \multicolumn{1}{c}{ Advantages } & \multicolumn{1}{c}{ Limitations } \\
\hline & $\begin{array}{l}\text { Mill out sections (windows) of Reliably restores external mechanical integrity. } \\
\text { casing at selected intervals. } \\
\text { Underream to remove old } \\
\text { cement. Place a cement plug } \\
\text { across windows and apply Moderate amount of waste generated. } \\
\text { pressure (squeeze). }\end{array}$ & $\begin{array}{l}\text { Cannot be used in wells with inside diameters } \\
\text { of less than } 4 \text { in. Complex equipment increases } \\
\text { potential for delays. Downhole equipment } \\
\text { difficult to decontaminate. }\end{array}$ \\
Removal & $\begin{array}{l}\text { Moderately expensive, but less expensive than } \\
\text { casing removal. }\end{array}$ \\
$\begin{array}{l}\text { Remove inner casing or tubing } \text { If successful, restores external mechanical } \\
\text { selected depth. Drill out old } \\
\text { cement. Plug wellbore with Not limited by well diameter. } \\
\text { cement. }\end{array}$ & $\begin{array}{l}\text { Risk of drilling out of original well and being } \\
\text { unable to reenter. Greatest potential of worker } \\
\text { exposure or accidental surface release of } \\
\text { contaminants. }\end{array}$ \\
\hline
\end{tabular}


Table 6.3. Summary of well P\&A approaches for different well types

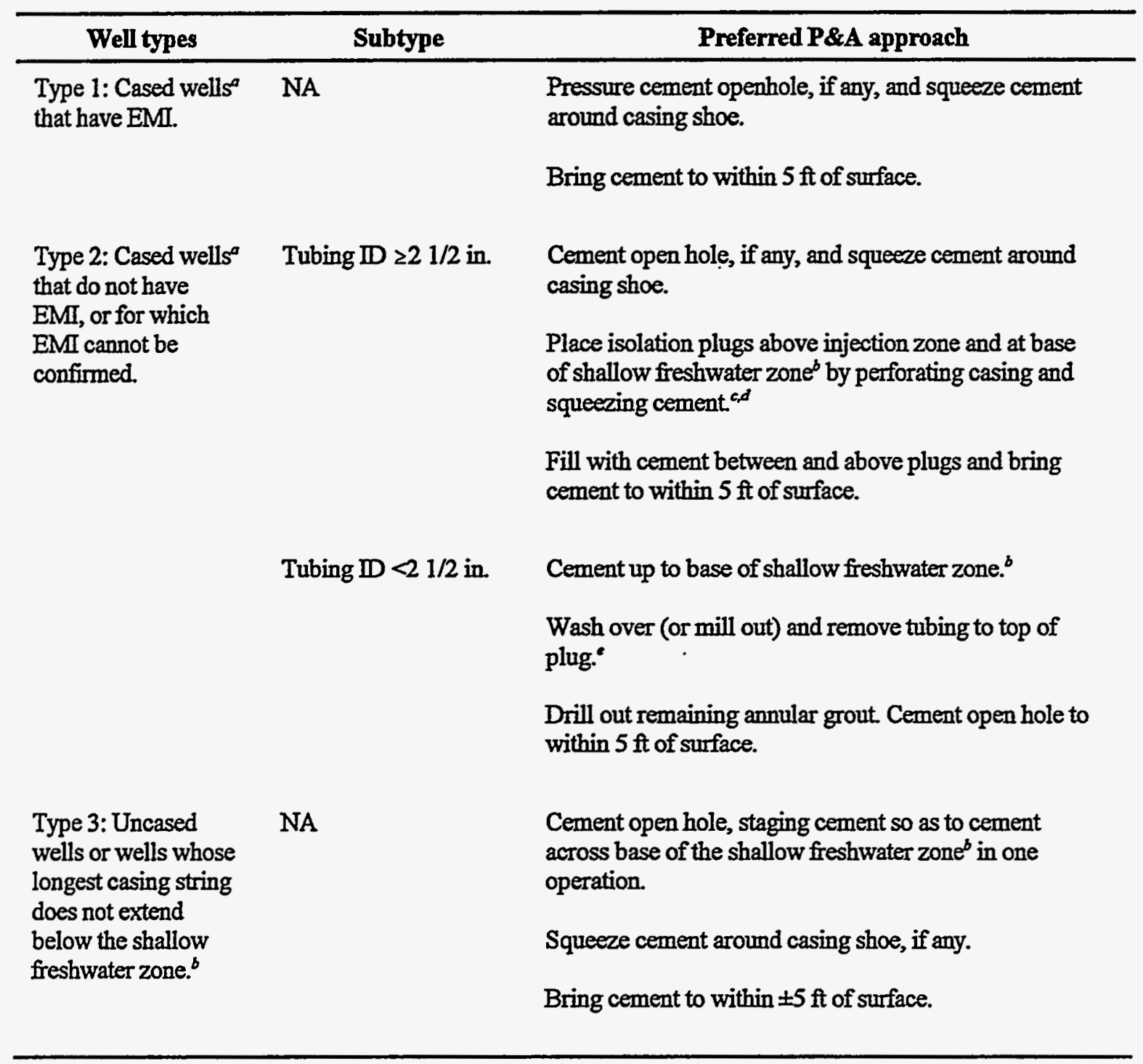

AAt least one casing or tubing string extends below the base of the shallow freshwater zone.

${ }^{b}$ The base of the shallow freshwater zone coincides with the top of the lower Maryville Limestone.

Milling windows through casing is an alternative to perforation for placement of isolation plugs in wells with an inside diameter of 24 in. and more certain in outcome, but generates more waste.

Themoval of casing and grout via washover or milling is an alternative to containment (e.g., perforating) if contaminant removal rather than isolation is preferred.

"An alternative to removal down to the base of the shallow freshwater zone is removal down to the "three finger" limestone above the injection zone.

Note: EMI = extemal mechanical integrity (no vertical groundwater flow between the casing and the borehole); NA $=$ not applicable. 
Table 6.4. Estimated waste volumes for proposed plugging and abandonment

\begin{tabular}{|c|c|c|c|c|c|c|}
\hline \multirow[b]{2}{*}{$\begin{array}{l}\text { Well } \\
\text { ID No. }\end{array}$} & \multirow[b]{2}{*}{$\begin{array}{c}\text { P\&A } \\
\text { Method }^{a}\end{array}$} & \multicolumn{5}{|c|}{ Waste Type } \\
\hline & & $\begin{array}{c}\text { Standing } \\
\text { Water( }\left(\mathrm{ft}^{5}\right)^{b}\end{array}$ & $\begin{array}{l}\text { Displacement } \\
\text { Fluid }\left(\mathrm{ft}^{3}\right)^{c}\end{array}$ & $\begin{array}{c}\text { Drilling } \\
\text { Fluid(f(t) }\end{array}$ & $\begin{array}{c}\text { Cutting } \\
\text { Solidss }\left(\mathrm{ft}^{3}\right)^{e}\end{array}$ & $\begin{array}{c}\text { Intact } \\
\text { Casing(linear } \mathrm{ft})^{f}\end{array}$ \\
\hline \multicolumn{2}{|c|}{ 玨 } & & \% & 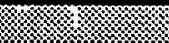 & & 9 \\
\hline 1969 & Cement-fill & 113 & 85 & 0 & 0 & 0 \\
\hline 1971 & Cement-fill & 101 & 76 & 0 & 0 & 0 \\
\hline 1973 & Cement-fill & 102 & 76 & 0 & 0 & 0 \\
\hline 1974 & Cement-fill & 101 & 76 & 0 & 0 & 0 \\
\hline 1976 & Cement-fill & 122 & 92 & 0 & 0 & 0 \\
\hline 1979 & Cement-fill & 122 & 92 & 0 & 0 & 0 \\
\hline 1980 & Cement-fill & 122 & 92 & 0 & 0 & 0 \\
\hline 1981 & Cement-fill & 113 & 85 & 0 & 0 & 0 \\
\hline \multicolumn{2}{|c|}{ 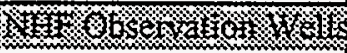 } & & 雬 & \% & & \\
\hline 1970 & Washover & 19 & 216 & 1,632 & 402 & 250 \\
\hline 1972 & Perforate & 101 & 76 & 0 & 0 & 0 \\
\hline 1975 & Perforate & 89 & 67 & 0 & 0 & 0 \\
\hline 1977 & Perforate & 109 & 81 & 0 & 0 & 0 \\
\hline 1978 & Perforate & 200 & 150 & 0 & 0 & 0 \\
\hline 1982 & Perforate & 104 & 78 & 0 & 0 & 0 \\
\hline \multicolumn{4}{|c|}{ 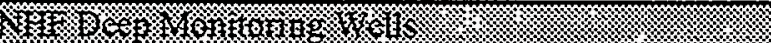 } & & 原 & $\%$ \\
\hline 2373 & Perforate & 201 & 150 & 0 & 0 & 0 \\
\hline 2374 & Perforate & 223 & 167 & 0 & 0 & 0 \\
\hline 2375 & Cement-fill & 357 & 268 & 0 & 0 & 0 \\
\hline 2952 & Cement-fill & 283 & 212 & 0 & 0 & 0 \\
\hline 2953 & Cement-fill & 107 & 81 & 0 & 0 & 0 \\
\hline 2954 & Perforate & 417 & 313 & 0 & 0 & 0 \\
\hline 2955 & Perforate & 417 & 313 & 0 & 0 & 0 \\
\hline \multicolumn{2}{|c|}{$(x)$} & & & & me & $\$$ \\
\hline 1920 & Cement-fill & 90 & 67 & 0 & 0 & 0 \\
\hline 1943 & Cement-fill & 116 & 86 & 0 & 0 & 0 \\
\hline 1945 & Cement-fill & 120 & 86 & 0 & 0 & 0 \\
\hline 1946 & Perforate & 57 & 42 & 0 & 0 & 0 \\
\hline 1947 & Cement-fill & 100 & 75 & 0 & 0 & 0 \\
\hline 1948 & Washover & 18 & 198 & 1,510 & 370 & 285 \\
\hline 1949 & Perforate & 70 & 52 & 0 & 0 & 0 \\
\hline 1950 & Cement-fill & 107 & 80 & 0 & 0 & 0 \\
\hline 1951 & Cement-fill & 111 & 87 & 0 & 0 & 0 \\
\hline 1952 & Cement-fill & 94 & 71 & 0 & 0 & 0 \\
\hline 1953 & Cement-fill & 168 & 104 & 0 & 0 & 0 \\
\hline 1954 & Washover & 18 & 208 & 1,590 & 390 & 300 \\
\hline 1955 & Cement-fill & 107 & 80 & 0 & 0 & 0 \\
\hline 1956 & Cement-fill & 113 & 84 & 0 & 0 & 0 \\
\hline 1957 & Cement-fill & 95 & 71 & 0 & 0 & 0 \\
\hline 1958 & Washover & 17 & 195 & 1,484 & 364 & 280 \\
\hline 1959 & Cement-fill & 105 & 79 & 0 & 0 & 0 \\
\hline
\end{tabular}


Table 6.4. Estimated waste volumes for proposed plugging and abandonment (continued)

\begin{tabular}{|c|c|c|c|c|c|c|}
\hline \multirow[b]{2}{*}{$\begin{array}{l}\text { Well } \\
\text { ID No. }\end{array}$} & \multirow[b]{2}{*}{$\begin{array}{c}\text { P\&A } \\
\text { Method }^{a}\end{array}$} & \multicolumn{5}{|c|}{ Waste Type } \\
\hline & & $\begin{array}{c}\text { Standing } \\
\left.\text { Water( } \mathrm{ft}^{3}\right)^{b}\end{array}$ & $\begin{array}{l}\text { Displacement } \\
\text { Fluid }\left(\mathrm{ft}^{3}\right)^{c}\end{array}$ & $\begin{array}{l}\text { Drilling } \\
\left.\text { Fluid( } \mathrm{ft}^{3}\right)^{d}\end{array}$ & $\begin{array}{c}\text { Cutting } \\
\text { Solids }\left(\mathrm{ft}^{3}\right)^{e}\end{array}$ & $\begin{array}{c}\text { Intact } \\
\text { Casing(linear } \mathrm{ft})^{y}\end{array}$ \\
\hline \multicolumn{7}{|c|}{ (6) } \\
\hline 1960 & Cement-fill & 106 & 80 & 0 & 0 & 0 \\
\hline 1961 & Perforate & 95 & 71 & 0 & 0 & 0 \\
\hline 1962 & Washover & 18 & 195 & 1,567 & 385 & 280 \\
\hline 1963 & Cement-fill & 119 & 90 & 0 & 0 & 0 \\
\hline 1964 & Washover & 18 & 186 & 1,404 & 344 & 530 \\
\hline 1965 & Perforate & 55 & 83 & 0 & 0 & 0 \\
\hline 1966 & Washover & 85 & 186 & 1,219 & 299 & 230 \\
\hline 1967 & Perforate & 117 & 88 & 0 & 0 & 0 \\
\hline Sum & & 5,645 & 5,490 & 10,406 & 2,554 & 2,155 \\
\hline
\end{tabular}

Note:

a. Proposed P\&A methods:

Cement-fill: fill with column of cement squeeze cement as necessary

Perforate: perforate with shaped charges and squeeze cement.

Washover: overdrill and remove casing to Lower Maryville, fill with cement.

b. Standing water is estimated to be two well volumes.

c. Displacement fluid waste is estimated to be 1.5 well volumes. Wells for which casing removal is recommended, the displacement fluid is the calculated volume of the under reamed hole, plus the volume of casing and open hole below under reamed depth.

d. Drilling mud is estimated to be 12 well volumes based on the calculated volume of the under reamed hole.

e. Cutting solids are based on the volume of the under reamed hole, minus the interior volume of the casing removed, multiplied by a "bulking" factor of 3 .

f. Intact casing is removed by washing over. 
4 


\section{WELL CLASSIFICATION AND PLUGGING AND ABANDONMENT RECOMMENDATIONS}

This chapter presents a summary of the methodology used to classify the 21 wells associated with hydrofracture operations at NHF. Recommendations are made for the preferred method of plugging and abandoning the wells (Volume 2) or considering use of wells for temporary site monitoring. The well evaluations and interpretations of the present condition of each NHF well, based on historical and investigation derived data; geophysical logs, geochemical data, radiochemical data, and historical records of construction and operations were used to develop conclusions on the current state of the wells and potential future actions for the wells. NHF well construction details are given in Table 2.5. The complete discussion and interpretation plus a data summary for each well is contained in Volume 2.

The well ranking method used is consistent with that used previously for OHF associated wells (BNI 1995c, 1996). The qualitative ranking of the wells is provided in Table 7.1 and the well locations with rankings are shown on Fig. 7.1. The NHF wells are integrated with the OHF wells to assist in planning for final disposition of the wells.

The well rank was derived by assigning a numerical score of 1 to 3 each for contamination, migration potential, and well integrity. Contamination (C) is defined as the concentration of aqueous hazardous constituents, primarily radiological, observed in the wellbore water based on grab sampling the top, middle, and bottom of the standing water column. The sampling methodology and analytical methods are presented in Volume 2. A score of 1 indicates low contamination. A score of 3 was assigned to the most contaminated wells, due to high concentrations of radionuclides.

The migration potential (MP) score is based on detected migration of contaminants up the wellbore or inferred migration within the well annulus. Wellbore migration was typically determined by evaluating and interpreting the geophysical $\log$, hydrologic conditions, TDS, radionuclides, and/or nitrate within the standing water column or presumed flux of water in and/or out of the wellbore. The contamination and migration potential scores are independent. A migration potential score of 1 indicates that the well does not show strong evidence of significant transport within the wellbore, whereas a score of 3 indicates the highest degree of transport within the wellbore. Transport is generally, but not necessarily, from bottom to top. Higher contaminant concentrations were observed in the top or middle of some wells rather than the bottom.

The well integrity (WI) score, derived from interpretation of the borehole geophysical logs, is based on the following:

- Interpreted physical condition of the well casing,

- Physical and chemical characteristics of the water in the borehole,

- Physical and chemical characteristics of the geologic formations logged,

- Physical and chemical characteristics of the injected contaminated grout, and

- Interpreted casing-to-grout-to-formation bond. 
The integrity score for the well casing and grout quantifies the efficiency of the well completion in preventing the flux of formation water into the wellbore and/or potential migration of grout filtrate up the well annulus. A score of 1 indicates a low degree of flux of formation water through the well casing, whereas a score of 3 indicates poor isolation of the wellbore from the formation. Well integrity was evaluated independent of the contamination and/or migration potential scores. The geophysical logs provided critical data that was needed to evaluate the wells.

Well-specific summaries with well construction details, representative geophysical logs, radiological and chemical data (recent and historical), plus anion/cation and TDS/conductivity plots are provided in Volume 2. Modern geophysical logs could not be run in small-diameter Well 1970 or Well 1972 (bent riser). The gamma ray logs provided for these wells (Volume 2, Figs. 2.2.2 and 2.3.2) are historical and were recovered from NHF operation files. Complete suites of logs are available from the Energy Systems, Geology, Geophysics, and Geochemistry Group. A summary of the qualitative well rankings is given in Table 7.2.

Evidence of EMI or the lack of EMI was determined through interpretation of logs (variable density $\log (\mathrm{VDL})$, temperature, fluid resistivity, and caliper) that would indicate wellbore and/or annular flow. The wells were then classified based on this interpretation. The 21 wells studied in the WAG $10 \mathrm{NHF}$ investigation plus the OHF wells are classified based on EMI in Table 7.3. The groupings of wells were made using the procedure established for the OHF study, and the OHF wells are included in the table (BNI 1995c).

Each individual well is discussed in Volume 2. The reader is directed to that volume for those discussions. The individual well sections are organized with a complete discussion concerning the well condition and contamination followed by a general step-by-step recommended P\&A plan. 

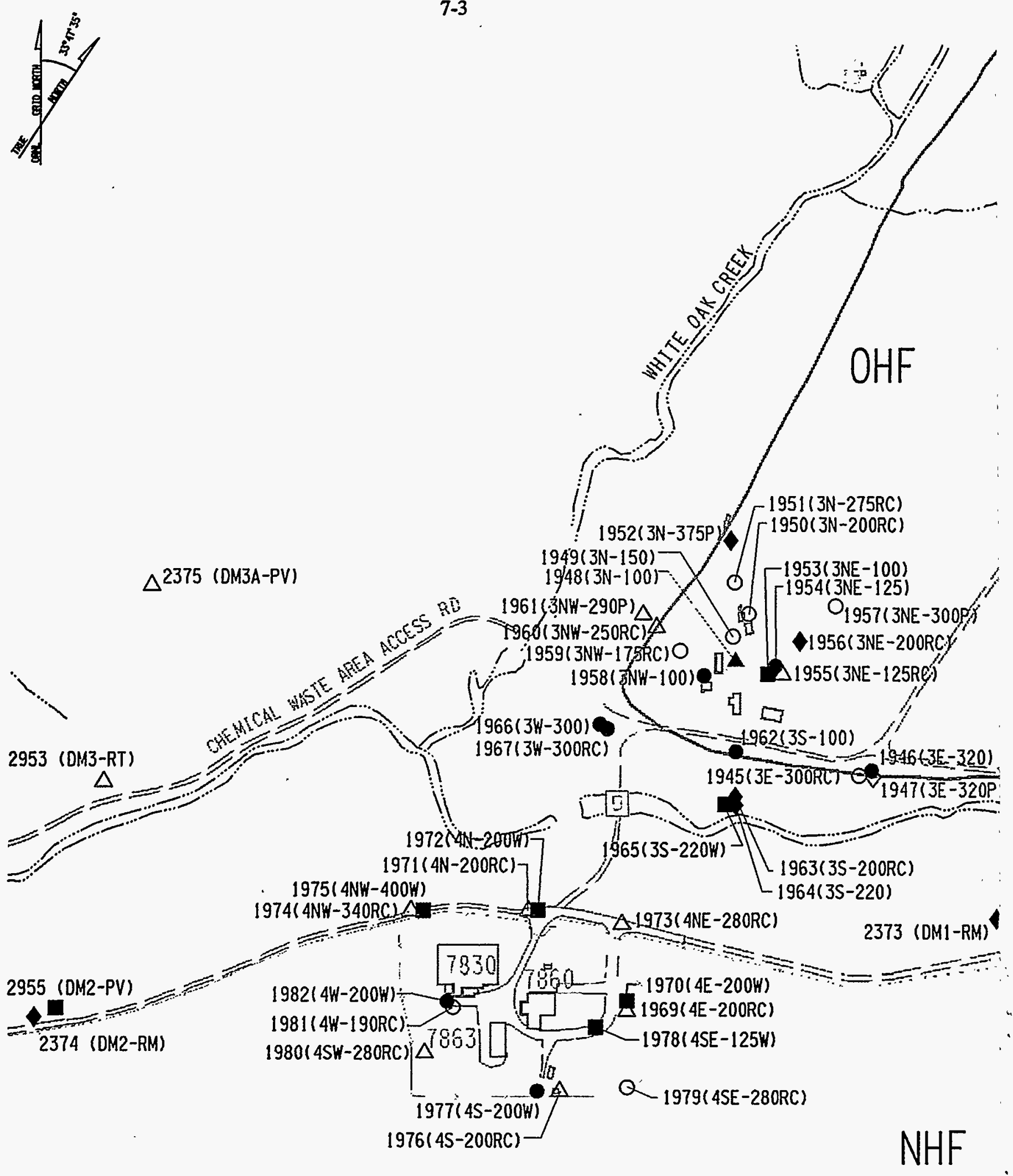


\begin{tabular}{|c|c|c|}
\hline $\begin{array}{l}\text { Well } \\
\text { (Alias) }\end{array}$ & Well Construction & Chemistry \& Contamination \\
\hline $\begin{array}{l}1975 \\
(4 \mathrm{NW}- \\
400 \mathrm{~W})\end{array}$ & $\begin{array}{l}\text { - Well does not appear to extend into the Rome Formation. } \\
\text { Well was discovered to be plugged before initial injections at NHF. } \\
\text { Recompleted before injection SI-3. } \\
\text { - Well is artesian and presently shut-in. } \\
\text { - Gamma ray counts begin to increase below }=550 \mathrm{ft} \text { due to contribution } \\
\text { from waste grout. Counts within the grout sheets }>15,000 \mathrm{cps} \text {. } \\
\text { - Temperature increase noted at top of grout sheets. } \\
\text { - Caliper measures joints at } 30 \mathrm{ft} \text { and } 3 \text { slightly different diameters. } \\
\text { - Casing bonding is poor from top of well to TD. } \\
\text { Historical records indicate possible casing offset at }=700 \mathrm{ft} \text {. } \\
\text { Well does not have EMI. }\end{array}$ & $\begin{array}{l}\text { Gross beta }(11.7 \mu \mathrm{Ci} / \mathrm{L}) \text { and gamma activity }(14.3 \mu \\
\text { extremely high. } \\
\text { The bottom sample contains very high activities for } \\
(0.02 \mu \mathrm{Ci} / \mathrm{L}), \mathrm{Cs}-137(14 \mu \mathrm{Ci} / \mathrm{L}), \mathrm{Sr}-90(0.04 \mu \mathrm{Ci} / \mathrm{L}) \\
(1.7 \mu \mathrm{Ci} / \mathrm{L}) \text {. } \\
\text { Nitrate was detected at } 12,600 \mathrm{mg} / \mathrm{L} \text { in bottom sam } \\
\text { The pHs measured indicate reaction with grout. } \\
\text { Fresh water in the upper two samples. Bottom sam } \\
\text { saline (TDS }=90,000 \mathrm{mg} / \mathrm{L}) \text {. } \\
\text { No organics detected at significant levels. }\end{array}$ \\
\hline $\begin{array}{l}2955 \\
\text { (DM2-PV) }\end{array}$ & $\begin{array}{l}\text { - Well has an open interval in the Pumpkin Valley Shale. } \\
\text { Pressure } 12.2 \text { psig at tapping. } \\
\text { - Well is artesian and presently shut-in. } \\
\text { - Galiper indicates narrowing of casing between } 621 \text { and } 638 \mathrm{ft} \\
\text { counts downhole. } \\
\text { Gamma peak at } 1044 \mathrm{ft} \text { correlates with temperature and caliper (hole } \\
\text { - Thlargement). } \\
\text { - Bonding is good. } \\
\text { - Constructed with } 20 \mathrm{ft} \text { casing. } \\
\text { Well does not have EMI. }\end{array}$ & $\begin{array}{l}\text { - } \quad \text { Gross beta activity is very high at } 2.6 \text { to } 9.2 \mu \mathrm{Ci} / \mathrm{L} \text {. } \\
\text { - } \quad 0 \text { etected activities for } \mathrm{Sr}-90(2.1 \text { to } 4.5 \mu \mathrm{Ci} / \mathrm{L}), \mathrm{H}-3 \text {. } \\
\text { - } 07 \mu \mathrm{Ci} / \mathrm{L}) \text { and } \mathrm{C}-14(220.7 \text { to } 1020.7 \mathrm{pCi} / \mathrm{L}) \text {. } \\
\text { Cs-137 was not detected. } \\
\text { - Nitrate concentration ranges from } 231 \text { to } 2040 \mathrm{mg} / \mathrm{L} \\
\text { - The pHs indicate basic water }(7.4 \text { to } 9.00) \text {. } \\
\text { - } \quad \text { Off-site analysis indicates high harium }(643 \mathrm{mg} / \mathrm{L}) \text {. } \\
\text { - No organics detected at significant levels. }\end{array}$ \\
\hline & 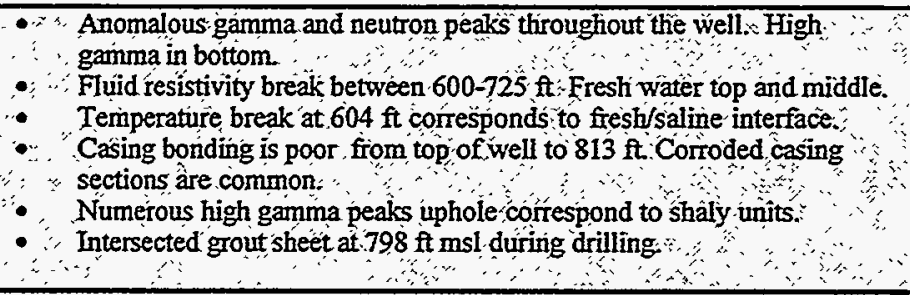 & $\begin{array}{l}\text { Total beta and gamma about } 15,000 \text { pCil and } 1,100 \\
\text { respectively, at bottom. Order-of-magnitude decre: } \\
\text { middle and top } \\
\text { Nitrate exceeds } 7,000 \text { mg/l in bottom sample } \\
\text { Eresh water in upper samples. Bottom sample is sali } \\
=57,000 \text { mg/L) }\end{array}$ \\
\hline $\begin{array}{l}1982 \\
(4 \mathrm{~W}-200 \mathrm{~W})\end{array}$ & $\begin{array}{l}\text { Well is set in the top of the Rome Formation. } \\
\text { Well is flowing artesian. } \\
\text { - } \quad \text { Gamma ray counts begin to increase below }=672 \mathrm{ft} \text { due to contribution } \\
\text { from waste grout. Counts within the grout sheets }>15,000 \mathrm{cps} \text {. } \\
\text { - Bonding varies from good (top of hole) to poor (bottom of hole). } \\
\text { Temperature indicates both flow within and outside casing, and also } \\
\text { probable relatively major zone of mixing ( } 970 \text { to total logged depth). } \\
\text { Caliper indicates that some waste grout may be present in casing below } \\
\text { - Cons } \mathrm{ft} \text {. } \\
\text { - Well does not have EMI. }\end{array}$ & $\begin{array}{l}\text { - Gross beta }(0.14 \mu \mathrm{Ci} / \mathrm{L}) \text { and gamma activity }(0.02 \mu t \\
\text { high. } \\
\text { The bottom sample contains very high activities for }( \\
(0.02 \mu \mathrm{Ci} / \mathrm{L}), \mathrm{Sr}-90(0.28 \mu \mathrm{Ci} / \mathrm{L}), \text { and } \mathrm{H}-3 \text { ( } 3213.5 \mathrm{p} \text { ( } \\
\text { - Nitrate was detected at } 18.7 \mathrm{mg} / \mathrm{L} \text { in bottom sample. } \\
\text { - The pHs are strongly basic and indicate reaction wit } \\
\text { - Fresh water in the upper sample and brackish water } \\
\text { lower two samples (TDS } \approx 1,600 \mathrm{mg} / \mathrm{L}) \text {. } \\
\text { - No organics detected at significant levels. }\end{array}$ \\
\hline $\begin{array}{l}1967 \\
(3 W-300 \mathrm{R}\end{array}$ & $\begin{array}{l}\text { Two breaks in fluid resistivity Tog; near top and about } 520 \mathrm{ft} \\
\text { One zone of precipitation andor corrosion in casing } \\
\text { Good cement bond to bottom of casing (617.8 ft) } \\
\text { Openhole interval in the lower Rutledge thmestone } \\
\end{array}$ & 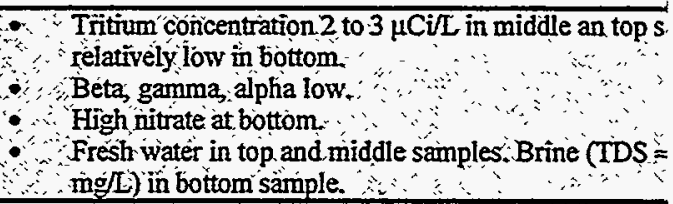 \\
\hline $\begin{array}{l}1966^{\circ} \\
(J O Y-1) \\
(3 W-300)\end{array}$ & $\begin{array}{l}\text { Cased to total depth } \\
\text { Reported as plugged } \\
\text { Breached during or before injection } \mathrm{ILW} \text { W and ILW } \\
\text { Opentiole logs available } \\
\text { Reported to be artesian }\end{array}$ & $\begin{array}{l}\text { Intercepted by grout sheets. } \\
\text { Assumed contaminated because of reported breachir } \\
\text { diameter wells during injections. }\end{array}$ \\
\hline
\end{tabular}


Table 7.1. Summary of well log and well water chemical information (continued)

\begin{tabular}{|c|c|c|c|c|c|c|}
\hline & Interpretation & Conclusions & C & MP & WI & Total \\
\hline $\begin{array}{l}\text { L) are } \\
-60 \\
\text { nd } H-3\end{array}$ & $\begin{array}{l}\text { The radiological contaminants in the standing water column in } \\
\text { this well mimic and are sourced from the waste grout injected } \\
\text { at NHF. The activities are very high. The well is in poor } \\
\text { condition and had been previously recompleted. The well is } \\
\text { artesian, but presently shut-in. The measured pHs indicate } \\
\text { reaction with grout (construction or waste?). }\end{array}$ & $\begin{array}{l}\text { The standing water within this artesian well is highly } \\
\text { contaminated with radiological constituents sourced } \\
\text { from the grout sheets. The possibility of contaminant } \\
\text { migration, through the well annulus, to the fresh } \\
\text { water (upper Maryville Limestone) and/or surface is } \\
\text { high. The well is presently shut-in, so surface release } \\
\text { out the wellbore has been temporarily controlled. The } \\
\text { wellhead, however, will need to be maintained to } \\
\text { ensure integrity. } \\
\text { This well should have a very high priority for plugging } \\
\text { and abandonment. }\end{array}$ & 3 & 3 & 3 & 9 \\
\hline 4 to & $\begin{array}{l}\text { The standing water in this well is highly contaminated with } \\
\text { radionuclides that were/are sourced from the waste grout } \\
\text { sheets injected at NHF. A passive gamma peak measured on } \\
\text { the new log is not present on an old gamma log run in well } \\
2374 \text {. The gamma peak was "formed" by filtrate that flowed } \\
\text { (flowing?) through hydrofracture induced and/or natural } \\
\text { fractures and intercepted well } 2955 \text {. Evidence indicates that } \\
\text { the filtrate was still migrating between } 1985 \text { and } 1995 \text {. }\end{array}$ & $\begin{array}{l}\text { The radiological contaminants activities in the } \\
\text { standing water column in this well are extremely high. } \\
\text { The probability of upward migration of radionuclide } \\
\text { contaminated brine through the wellbore and/or } \\
\text { annulus is high. Presently, the well is shut-in. This } \\
\text { wellhead will require continual maintenance to } \\
\text { protect the health, safety, and the environment. } \\
\text { This well should have a very high priority for } \\
\text { plugging and abandonment. }\end{array}$ & 3 & 3 & $\overline{3}$ & 9 \\
\hline $\begin{array}{l}\text { lop; } \\
\text { eat: } \\
\therefore \text { (i) }\end{array}$ & 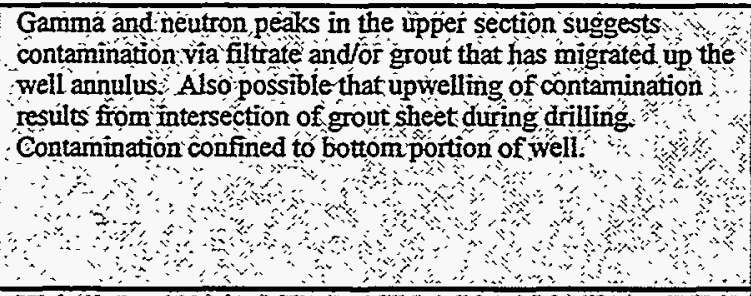 & 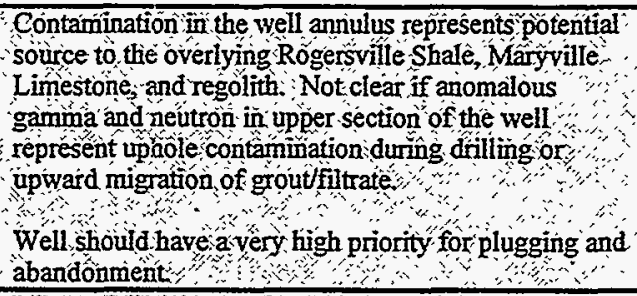 & 3 & & & 9 \\
\hline & 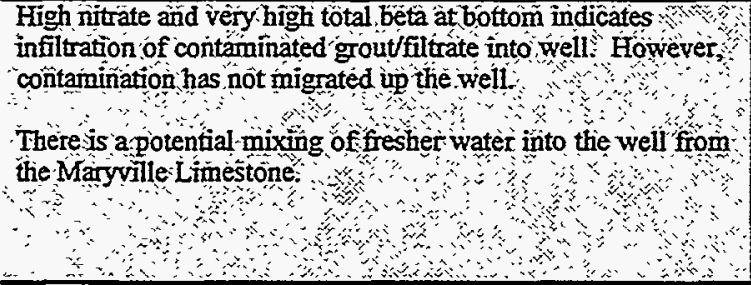 & 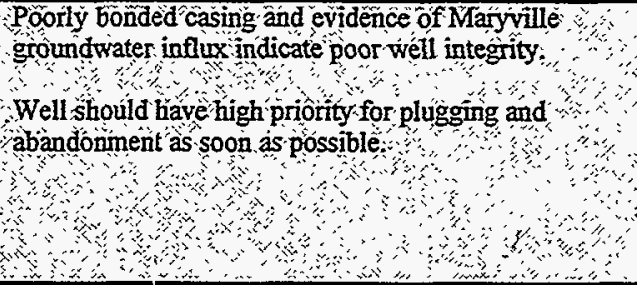 & 3 & & 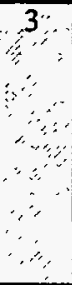 & \\
\hline $\begin{array}{l}\text { iL) are } \\
\text {-137 } \\
\text { (L). } \\
\text { grout. } \\
\text { ithe }\end{array}$ & $\begin{array}{l}\text { The radiological contaminants in the standing water column in } \\
\text { this well are relatively high and mimic the waste grout } \\
\text { injected at NHF. The well is flowing artesian, but presently } \\
\text { shut-in. Shut-in pressure increased to } 113 \text { psig. The } \\
\text { measured pHs indicate reaction with grout (construction or } \\
\text { waste?). }\end{array}$ & $\begin{array}{l}\text { The radiological contaminants in the standing water } \\
\text { column in this well are relatively high and mimic the } \\
\text { waste grout injected at NHF. The well is flowing } \\
\text { artesian, but presently shut-in. Shut-in pressure } \\
\text { increased to } 113 \text { psig. The measured pHs indicate } \\
\text { reaction with grout (construction or waste?). } \\
\text { This well should have high priority for plugging and } \\
\text { abandonment. }\end{array}$ & 2 & 3 & 3 & 8 \\
\hline $\begin{array}{c}10,000 \\
100 \\
0\end{array}$ & 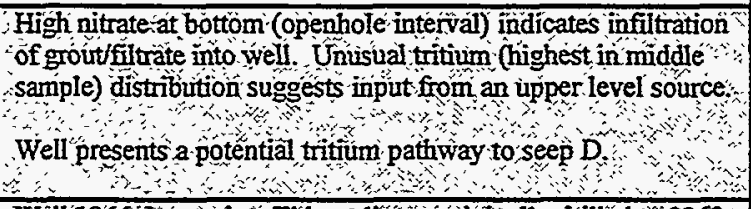 & 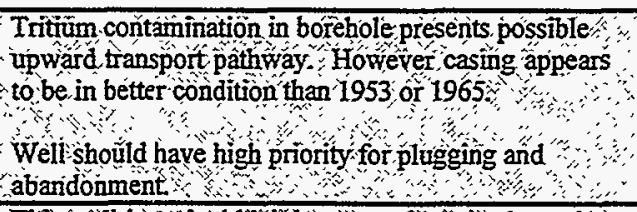 & & & 3 & \\
\hline $\begin{array}{ccc}0 \\
0 \\
0\end{array}$ & 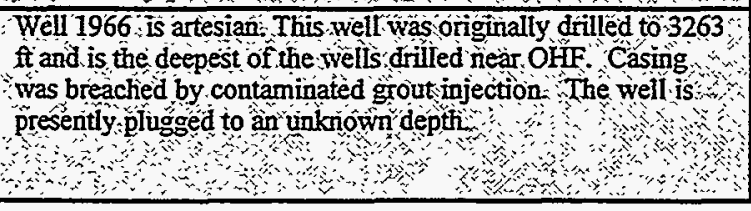 & 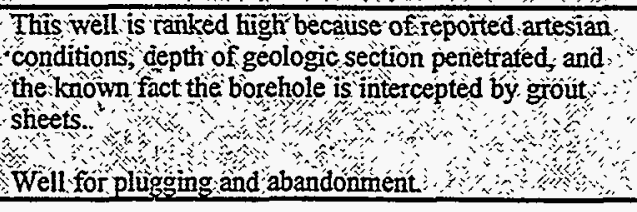 & & & & \\
\hline
\end{tabular}




\begin{tabular}{|c|c|c|}
\hline $\begin{array}{l}\text { Well } \\
\text { (Alias) }\end{array}$ & Well Construction & Chemistry \& Contamination \\
\hline $\begin{array}{l}2374 \\
\text { (DM2-RM) }\end{array}$ & $\begin{array}{l}\text { - Well was recompleted and is presently set in the top of the Rome } \\
\text { Formation. } \\
\text { - Goubly cased to } 550 \mathrm{ft} \text {. } \\
\text { Gamma } \log \text { is abnormal for area and displays gradual increase in } \\
\text { counts downhole. } \\
\text { - Gamma peaks at } 718,894 \text {, and } 910 \mathrm{ft} \\
\text { - Nonding seems to be poor over doubly cased section. } \\
\text { - Constructed with } 20 \mathrm{ft} \text { casing. } \\
\text { - Well does have EMI. }\end{array}$ & $\begin{array}{l}\text { - Gross beta activity is } 0.2 \mu \mathrm{Ci} / \mathrm{L} \text {. } \\
\text { Detected activities for } \mathrm{Cs}-137(<45 \mathrm{pCi} / \mathrm{L}), \mathrm{Sr}-90(0 \\
\text { and } \mathrm{C}-14(0.08 \mu \mathrm{Ci} / \mathrm{L}) \text {. } \\
\text { The pHs range from near neutral to acidic (bottom t } \\
\text { sample). } \\
\text { The water is } \mathrm{NaCl} \text { brine (TDS } \geq 104,931 \mathrm{mg} / \mathrm{L}) \text {. Thi } \\
\text { two samples are high saline brine }(>266,000 \mathrm{mg} / \mathrm{L}) \text {. } \\
\text { No organics detected at significant levels. }\end{array}$ \\
\hline $\begin{array}{c}1956 \\
(3 \mathrm{NE}-200 \mathrm{R}) \\
\end{array}$ & 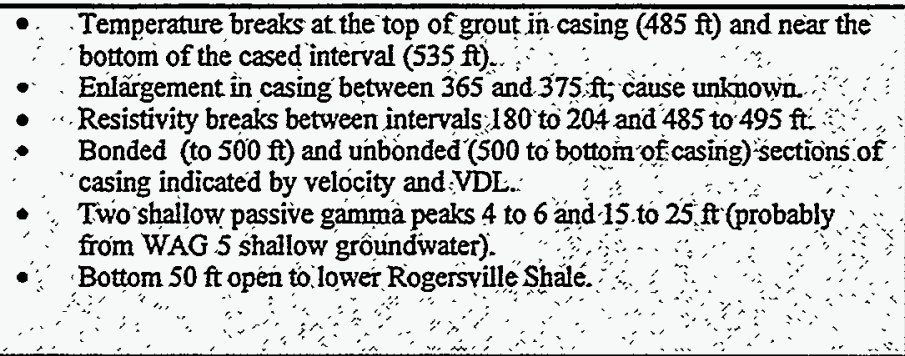 & 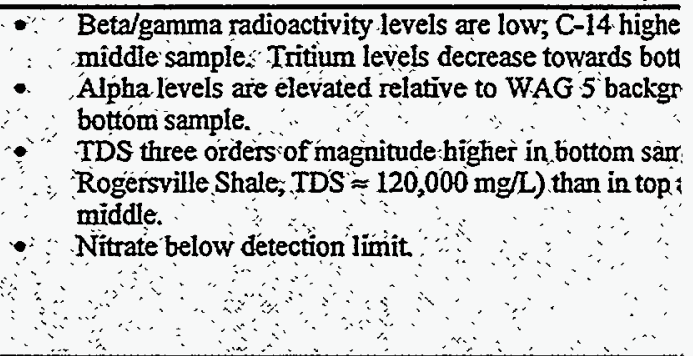 \\
\hline $\begin{array}{l}1952 \\
(3 \mathrm{~N}-375 \mathrm{P})\end{array}$ & $\begin{array}{l}\text { Temperature breaks at } 210 \text {; corresponding with a joint other breaks at } \\
230 \text { and } 432 \mathrm{ft} \\
\text { Interval } 210-230 \text { indicates a resistivity change (increase in TDS) and } \\
\text { an interval of possible corrosion or precipitation in the well, and a peak } \\
\text { on the SRR } \\
\text { Casing is well bonded from } 60 \text { ft to bottom of casing } \\
\text { Variable diameter casing was used for well construction. } \\
\text { Overall poor integrity and construction } \\
\text { Approximately i2 ft of open interval in midde Ruttedge Limestone } \\
\text { (based on bottom of logged interval and reported TD) }\end{array}$ & 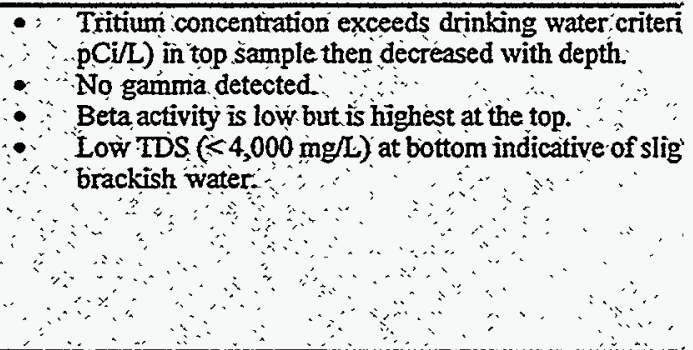 \\
\hline $\begin{array}{l}1963 \\
(3 S-200 R)\end{array}$ & $\begin{array}{l}\text { Temperature breaks (155,283,477, and } 508 \mathrm{ft} \text { ) conrelate with } \\
\text { joints/collars } \\
\text { Caliper indicates well is in poor condition; comoded and open atmost } \\
\text { joints. Well constructed from mix of casing diametêts } \\
\text { Resistivity log indicates brine near surface. } \\
\text { Cement bond is good from } 90 \text { to bottom of casing }(600 \mathrm{ft}) \\
\text { Open in the lower Rutledge Limestone. }\end{array}$ & 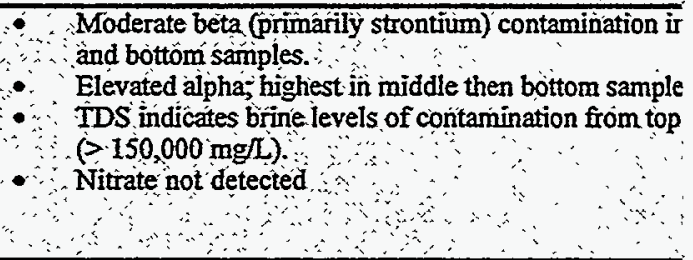 \\
\hline $\begin{array}{l}1981 \\
(4 W-190 R C)\end{array}$ & $\begin{array}{l}\text { - The openhole interval is within the Rogersville Shale/Rutledge } \\
\text { Limestone. } \\
\text { - Well constructed with } 30 \mathrm{ft} \text { casing that appears corroded. } \\
\text { Cement bonding based on VDL is interpreted to be poor from } 0 \text { to } 300 \\
\text { ft and good from } 300 \text { to the bottom of casing. } \\
\text { Temperature displays breaks at joints }(232,265 \text {, and } 300 \mathrm{ft}) \text { and over } \\
490 \text { to } 512 \mathrm{ft} \text {. } \\
\text { - Apparent density low from } 0 \text { to } 210 \mathrm{ft} \text { correlates interpreted bad } \\
\text { bonding. } \\
\text { - Cabling and geophones sanded up in the well. } \\
\text { Bonding may have been disturbed during past attempts to remove } \\
\text { cabling and geophones. } \\
\text { Well does not have EMI. }\end{array}$ & $\begin{array}{l}\text { - The water is acidic, high saline native brine }(>185,73 \\
\text { and composed of } \mathrm{NaCl} \text {. } \\
\text { - Minor nitrate }(\leq 48 \mathrm{mg} / \mathrm{L}) \text { detected in historical samp, } \\
\text { in recent samples). } \\
\text { Minor activity detected for } \mathrm{Sr}-90(\$ 351.4 \mathrm{pCi} / \mathrm{L}) \text { and } \\
\text { ( }(58.8 \mathrm{pCi} / \mathrm{L}) \text {. } \\
\text { No organics detected at significant levels. }\end{array}$ \\
\hline $\begin{array}{l}1979 \\
\text { (4SE-280RC) }\end{array}$ & $\begin{array}{l}\text { The openhole interval within the Rogersville Shale/Rutledge Limestone. } \\
\text { - Well constructed with } 30 \mathrm{ft} \text { casing. } \\
\text { - Cement bonding based on VDL is interpreted to be good to the bottom } \\
\text { of casing. } \\
\text { - Temperature and resistivity logs seem to indicate "microseparation" at } \\
\text { - Woints possibly caused by uplift/subsidence (masked on VDL). } \\
\text { Well does not have EMI. }\end{array}$ & 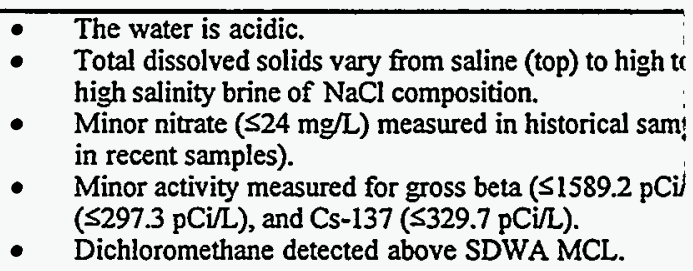 \\
\hline
\end{tabular}


Table 7.1. Summary of well $\log$ and well water chemical information (continued)

\begin{tabular}{|c|c|c|c|c|c|c|}
\hline & Interpretation & Conclusions & C & MP & WI & Total \\
\hline i $\mu \mathrm{Ci} / \mathrm{L})$, & $\begin{array}{l}\text { This well was originally installed with a long openhole } \\
\text { interval. High level of radiological contamination were } \\
\text { discovered. The makeup of the contaminants mimicked } \\
\text { filtrate sourced from the waste grout injected at NHF. Active } \\
\text { hydraulic fractures were discovered within the injection } \\
\text { horizon. Well recompleted in the Rome Formation. } \\
\text { Subsequent samplings indicated much lower activity levels. } \\
\text { Contaminants are believed to be relic and not representative } \\
\text { of contamination in the Rome Formation. Water in the lower } \\
\text { portion of the well is acidic. }\end{array}$ & $\begin{array}{l}\text { The radiological contaminants in the standing water } \\
\text { column in this well are moderately low and relic. } \\
\text { Wellbore could provide a pathway for upward } \\
\text { migration of contaminants and high saline brine water. } \\
\text { The measured pHs indicate acidic water. } \\
\text { This well should have a moderate priority for plugging } \\
\text { and abandonment. }\end{array}$ & 2 & 2 & 2 & 6 \\
\hline $\begin{array}{l}\text { in } \\
\text { n. } \\
\text { ind in } \\
\text { le (lower } \\
\text { id }\end{array}$ & 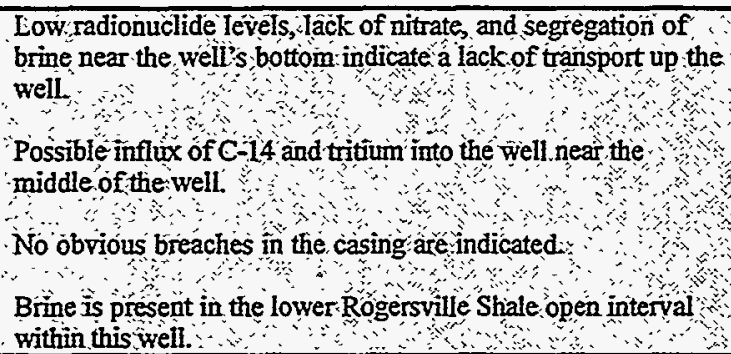 & 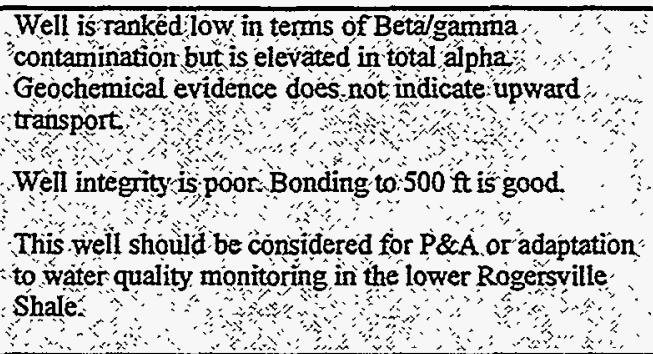 & 2 & & & 6 \\
\hline by & 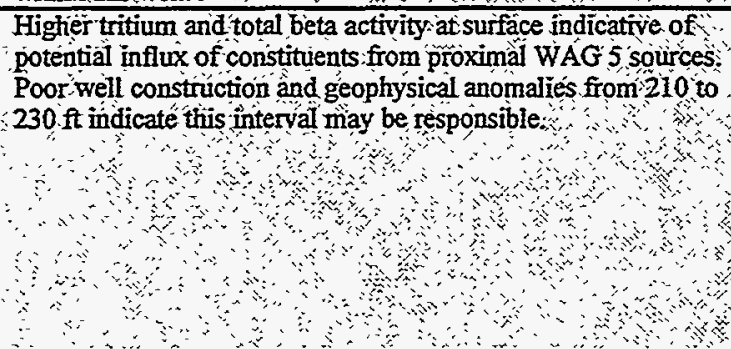 & 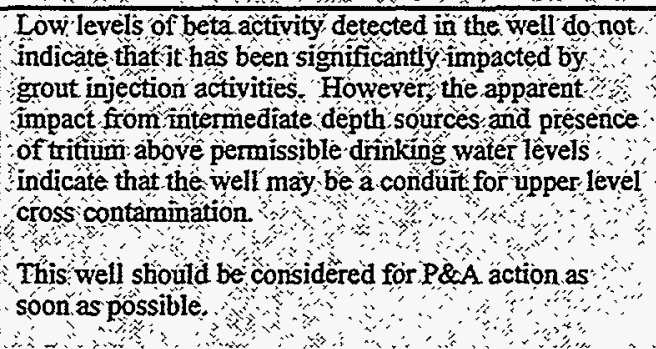 & 2 & Y & 2 & 6 \\
\hline 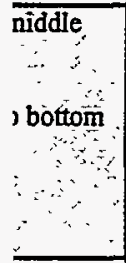 & 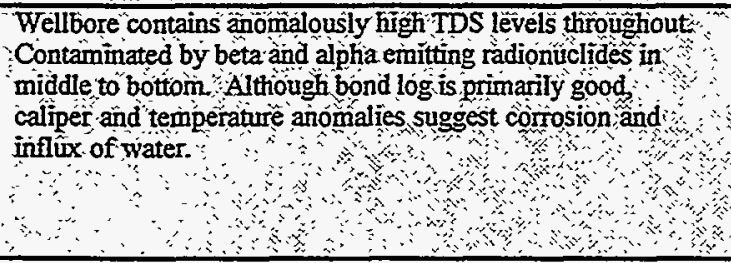 & 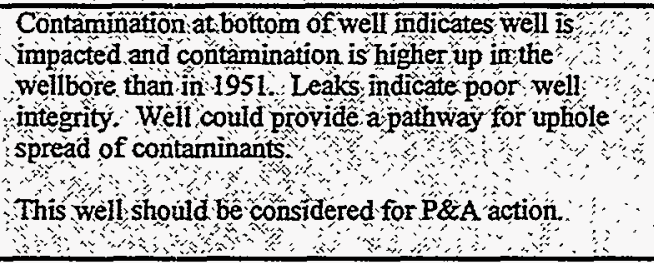 & 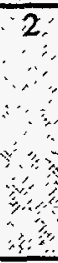 & 23 & $\overline{1}$ & 6 \\
\hline $\begin{array}{l}\mathrm{mg} / \mathrm{L} \text { ), } \\
\mathrm{s} \text { (none } \\
\text { s-137 }\end{array}$ & $\begin{array}{l}\text { The upper section of casing appears to be poorly bonded. } \\
\text { Temperature displays breaks at several joints. Minor } \\
\text { radiological contamination was detected. Nitrate was only } \\
\text { detected in historical samples. The grout sheets are not } \\
\text { believed to be the source of the contamination. Openhole } \\
\text { interval contains cabling and geophones that were abandoned } \\
\text { and sanded in. }\end{array}$ & $\begin{array}{l}\text { Well } 1981 \text { appears to be in poor condition. Openhole } \\
\text { interval is unusable. No attempt should be made to } \\
\text { remove the geophone string. This well is not suitable } \\
\text { for temporary monitoring. } \\
\text { This well should be considered for P\&A action. }\end{array}$ & 2 & 2 & 1 & 5 \\
\hline $\begin{array}{l}\text { rery } \\
\text { es (none } \\
\text { I, ST-90 }\end{array}$ & $\begin{array}{l}\text { Well } 1976 \text { appears to be in fairly good condition. } \\
\text { Temperature and resistivity logs may indicate } \\
\text { microseparations at joints caused by uplift/subsidence. Water } \\
\text { in the upper portion of the well is saline and may indicate } \\
\text { influx of fresher water into the wellbore. Radiological } \\
\text { contamination was detected. Nitrate was only detected in } \\
\text { historical samples. The grout sheets are not believed to be the } \\
\text { source of the contamination. }\end{array}$ & $\begin{array}{l}\text { Radiological contaminant levels are low and probably } \\
\text { reflect of past cross contamination. Well integrity } \\
\text { appears to be good, but there is some evidence of } \\
\text { influx of fresher water. Possible breaks in bonding at } \\
\text { joints. } \\
\text { This well should be considered for P\&A action. }\end{array}$ & 2 & 2 & 1 & 5 \\
\hline
\end{tabular}




\begin{tabular}{|c|c|c|}
\hline $\begin{array}{l}\text { Well } \\
\text { (Alias) }\end{array}$ & Well Construction & Chemistry \& Contamination \\
\hline $\begin{array}{l}1960 \\
(3 N W-250 \mathrm{R}) \\
\vdots \\
\therefore\end{array}$ & $\begin{array}{l}\text { Temperature break at } 237 \mathrm{ftat} \text { bottom of surface casing and at } 520 \mathrm{ft} \\
\text { at bottom of cased interval. } \\
\text { Transition to saline conditions at about } 100 \mathrm{ft} \\
\text { Caliper indicates openings on many joints } \\
\text { Possible scaling/corrosion over several intervals. } \\
\text { Casing well bonded from } 90 \text { to } 542 \mathrm{ft} \text { (bottom of casing) } \\
\text { Open interval in lower Rutledge Limestone }\end{array}$ & $\begin{array}{l}\text { Gamma and beta radioactivity is low, alpha is mode } \\
\text { decrease from bottom to top. } \\
\text { Tritium is very low but increases from bottom to top } \\
\text { TDS represents brine }(\approx 115,000 \text { mgl) in middle an } \\
\text { sample } \\
\therefore\end{array}$ \\
\hline $\begin{array}{l}2952 \\
\text { (DM1-RT) }\end{array}$ & $\begin{array}{l}\text { Well has an openhole interval within the Rutledge Limestone. } \\
\text { - Constructed with } 20 \mathrm{ft} \text { casing. } \\
\text { - VDL indicates good bonding. } \\
\text { - Well does have EMI. }\end{array}$ & $\begin{array}{l}\text { Top water sample is very basic (pH 11.26). lower t } \\
\text { acidic. } \\
\text { Total dissolved solids vary from saline (top) to very } \\
\text { salinity brine of } \mathrm{NaCl} \text { composition }(>222,000 \mathrm{mg} / \mathrm{L} \text { ) } \\
\text { bottom. } \\
\text { Minor nitrate }(\leq 18 \mathrm{mg} / \mathrm{L}) \text { measured in historical sam } \\
\text { in recent samples). } \\
\text { Minor activity measured for gross beta }(\leq 1513 . \mathrm{pCi} / \\
\text { historic), Sr-90 ( }(56756.8 \mathrm{pCi} / \mathrm{L} \text {, historic), and } \mathrm{Cs}-13 \\
\text { pCi } / \mathrm{L}, \text { recent). } \\
\text { No organics detected at significant levels. }\end{array}$ \\
\hline $\begin{array}{l}1969 \\
(4 \mathrm{NE}-200 \mathrm{RC})\end{array}$ & $\begin{array}{l}\text { - Well has an openhole interval within the Rogersville Shale/Rutledge } \\
\text { Limestone. } \\
\text { - Cement bonding is interpreted to be good to the bottom of casing. } \\
\text { - } \text { Temperature anomalies in the openhole section indicate flow through } \\
\text { - No indication of flow outside casing. } \\
\text { - Well does have EMI. }\end{array}$ & $\begin{array}{l}\text { The water is acidic high total dissolved solids, } \mathrm{NaCl} \\
\text { brine. } \\
\text { Very minor activity measured for Sr-90 }(\leq 64.9 \mathrm{pCi} / \\
\text { ( } \leq 293 \mathrm{pCi} / \mathrm{L}) \text {, and Co-60 }(\leq 3.5 \mathrm{pCi} / \mathrm{L}) \text {. } \\
\text { - Dichloromethane detected above SDWA MCL. }\end{array}$ \\
\hline $\begin{array}{l}1971 \\
(4 \mathrm{~N}-200 \mathrm{RC})\end{array}$ & $\begin{array}{l}\text { - Well has an openhole interval within the Rogersville Shale/Rutledge } \\
\text { Limestone. } \\
\text { - Cement bonding is interpreted to be good to the bottom of casing. } \\
\text { - Nome casing corrosion noted near joints. } \\
\text { - Geophones and cabling are sanded up in the bottom of the well (top at } \\
413 \mathrm{ft} \text { bgs). } \\
\text { - Well does have EMI. }\end{array}$ & $\begin{array}{l}\text { - The water is acidic, high total dissolved solids, } \mathrm{NaCl} \\
\text { brine. } \\
\text { Very minor activity measured for gross beta }(\leq 1621 \text {; } \\
\text { Sr-90 ( } \$ 73 \mathrm{pCi} / \mathrm{L}), \mathrm{Cs}-137(\leq 27 \mathrm{pCi} / \mathrm{L}) \text {, and } \mathrm{Co}-60 \text { (; } \\
\text { pCi/L). } \\
\text { Minor nitrate }(\leq 28 \mathrm{mg} / \mathrm{L}) \text {. }\end{array}$ \\
\hline $\begin{array}{l}1974 \\
\text { (4NW- } \\
\text { 340RC) }\end{array}$ & $\begin{array}{l}\text { Well has an openhole interval within the Rogersville Shale/Rutledge } \\
\text { Limestone. } \\
\text { - Well constructed with } 30 \mathrm{ft} \text { casing. } \\
\text { - Cement bonding is interpreted to be good to the bottom of casing. } \\
\text { - Well does have EMI. }\end{array}$ & $\begin{array}{l}\text { - The water is acidic, high total dissolved solids, } \mathrm{NaCl} \\
\text { brine. } \\
\text { Minor activity measured for gross beta }(\leq 2567.6 \mathrm{pCi} \\
(\leq 118.9 \mathrm{pCi} / \mathrm{L}), \mathrm{Cs}-137(\leq 18.6 \mathrm{pCi} / \mathrm{L}) \text {, and } \mathrm{Co}-60(\mathrm{Si} \\
\text { pCi/L). } \\
\text { - Minor nitrate }(\leq 54 \mathrm{mg} / \mathrm{L}) \text { measured in historical sam; } \\
\text { - No nitrate detected in recently collected/analyzed sa } \\
\text { No organics detected at significant levels. }\end{array}$ \\
\hline
\end{tabular}


Table 7.1. Summary of well log and well . water chemical information (continued)

\begin{tabular}{|c|c|c|c|c|c|c|}
\hline & Interpretation & Conclusions & $\mathrm{C}$ & MP & WI & Total \\
\hline $\begin{array}{l}\text { ite. All } \\
\text { botton } \\
\because \\
\cdots\end{array}$ & 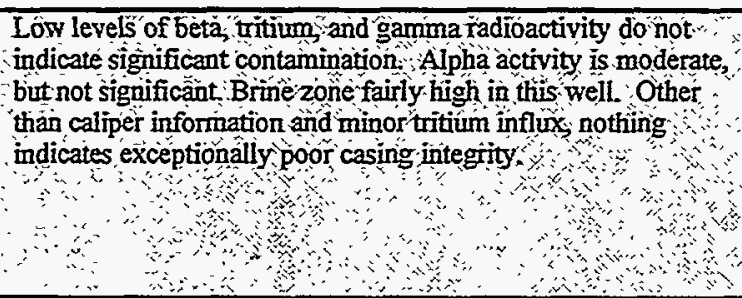 & 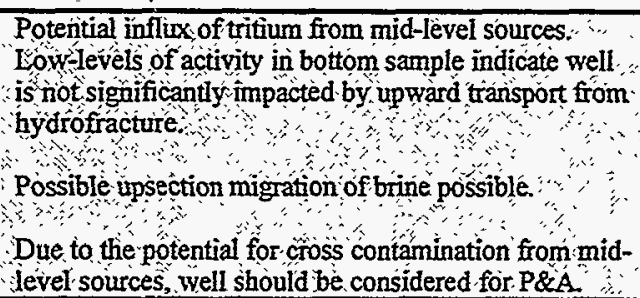 & 1 & $\begin{array}{l}\because \quad \therefore \\
\therefore \quad\end{array}$ & $\because \because$ & 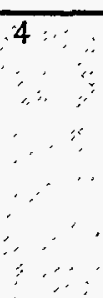 \\
\hline $\begin{array}{l}\text { o samples } \\
\text { gh } \\
\text { it the } \\
\text { 'es (none } \\
\text { ' }(\leq 53.4\end{array}$ & $\begin{array}{l}\text { Well } 2952 \text { appears to be in good condition. Water in the upper } \\
\text { portion of the well is saline and may indicate influx of fresher } \\
\text { water into the wellbore. The lowere portion of the well is } \\
\text { high saline brine. Radiological contamination was detected; } \\
\text { but is low. Nitrate was only detected at a low concentration } \\
\text { in historical samples. The grout sheets are not believed to be } \\
\text { the source of the contamination. }\end{array}$ & $\begin{array}{l}\text { Radiological contaminant levels are low and may } \\
\text { reflect past cross contamination. Well integrity } \\
\text { appears to be good, but there is some evidence of } \\
\text { influx of fresher water. Evidence of casing } \\
\text { corrosion. Casing will deteriorate caused by high } \\
\text { saline brine. } \\
\text { This well should be considered for P\&A action, } \\
\text { primarily because of the high saline brine. }\end{array}$ & 1 & 2 & I & 4 \\
\hline $\begin{array}{l}\text { itive } \\
\text {, Cs-137 }\end{array}$ & $\begin{array}{l}\text { This well appears to be in good condition with no evidence of } \\
\text { behind casing flow. Very minor radiological contamination is } \\
\text { noted. This contamination was not sourced from the grout } \\
\text { sheets. }\end{array}$ & $\begin{array}{l}\text { Radiological contaminant levels are low and probably } \\
\text { reflective of past cross contamination. Leakage of } \\
\text { brine groundwater to shallower (fresher) intervals is } \\
\text { possible. Well integrity, however, appears to be good. } \\
\text { This well should be considered for P\&A action. }\end{array}$ & 1 & 1 & 2 & 4 \\
\hline $\begin{array}{l}\text { ative } \\
\mathrm{pCi} / \mathrm{L}) \\
0.3\end{array}$ & $\begin{array}{l}\text { This well appears to be in fairly good condition with no direct } \\
\text { evidence of behind casing flow. Minor radiological } \\
\text { contamination and nitrate noted. This contamination was not } \\
\text { sourced from the grout sheets. }\end{array}$ & $\begin{array}{l}\text { Radiological contaminant levels are low and probably } \\
\text { reflective of past cross contamination. Low } \\
\text { concentration of nitrate measured in historical } \\
\text { samples. No nitrate in recent water samples. } \\
\text { Leakage of brine groundwater to shallower (fresher) } \\
\text { intervals is possible. Well integrity, however, appears } \\
\text { to be moderately good (some evidence of comosion). } \\
\text { This well should be considered for P\&A action. }\end{array}$ & 1 & 2 & 1 & 4 \\
\hline $\begin{array}{l}\text { solids, } \\
\text { i/L), Sr- } \\
\text { es. } \\
\text { ples. }\end{array}$ & $\begin{array}{l}\text { This well appears to be in fairly good condition. Minor } \\
\text { radiological contamination was measured. Nitrate was } \\
\text { detected in historical samples. No nitrate detected in the } \\
\text { recent sampling. This contamination was not sourced from } \\
\text { the grout sheets. }\end{array}$ & $\begin{array}{l}\text { Radiological contaminant levels are minor and } \\
\text { probably reflective of past cross contamination. } \\
\text { Leakage of brine groundwater to shallower (fresher) } \\
\text { intervals is possible. Well integrity, however, appears } \\
\text { to be moderately good. } \\
\text { This well should be considered for P\&A action. }\end{array}$ & 1 & 2 & 1 & 4 \\
\hline $\begin{array}{l}\text { ative } \\
\text {, Sr-90 } \\
.1 \\
\text { es. } \\
\text { ples. }\end{array}$ & $\begin{array}{l}\text { Well } 1974 \text { appears to be in fairly good condition. Minor } \\
\text { radiological contamination was measured. Nitrate was only } \\
\text { detected in historical samples. This contamination was not } \\
\text { sourced from the grout sheets. }\end{array}$ & $\begin{array}{l}\text { Radiological contaminant levels are minor and } \\
\text { probably reflective of past cross contamination. } \\
\text { Leakage of brine groundwater to shallower (fresher) } \\
\text { intervals is possible. Well integrity, however, appears } \\
\text { to be good. } \\
\text { This well should be considered for P\&A action. }\end{array}$ & 1 & 2 & 1 & 4 \\
\hline
\end{tabular}




\begin{tabular}{|c|c|c|}
\hline 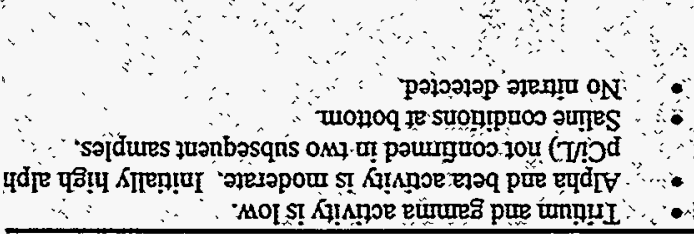 & 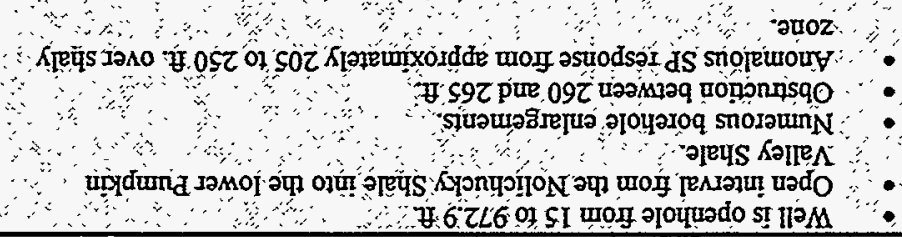 & 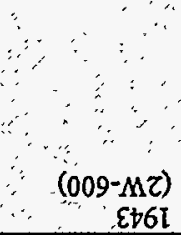 \\
\hline 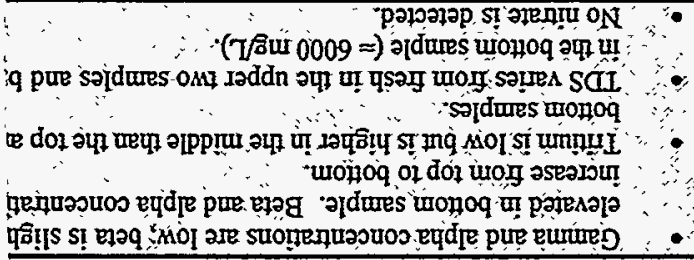 & 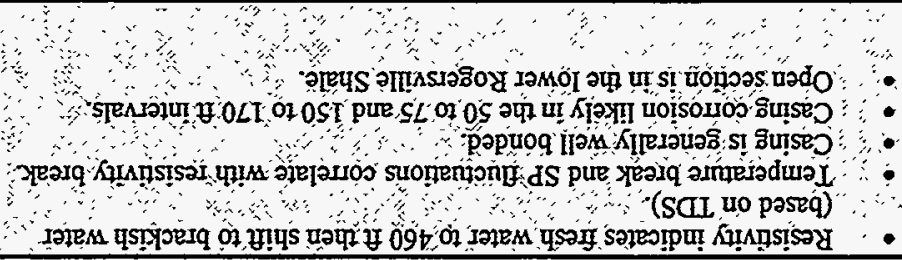 & $\because \begin{array}{r}(\mathrm{d} 0 z \varepsilon-\exists \varepsilon) \\
\hdashline \neq 6 I\end{array}$ \\
\hline 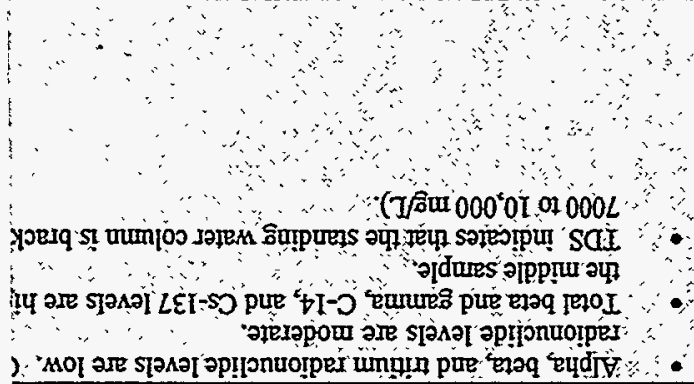 & 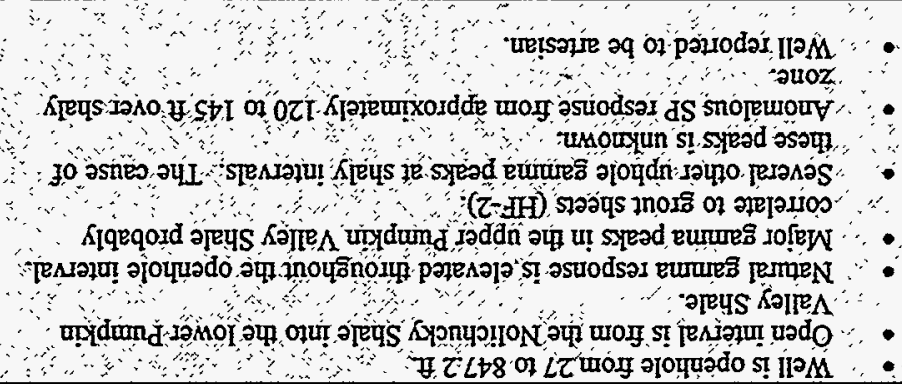 & 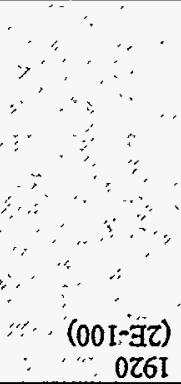 \\
\hline 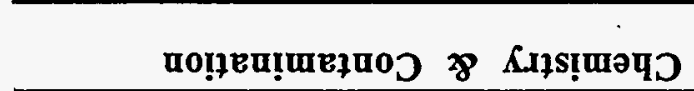 & 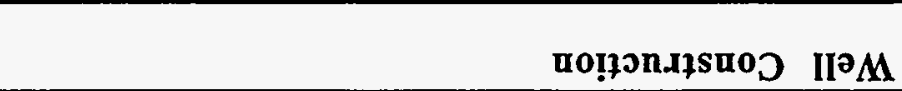 & \\
\hline
\end{tabular}




\section{7-13}

Table 7.3. Classification of New Hydrofracture Facility, Old Hydrofracture Facility, and monitoring wells at HF-2

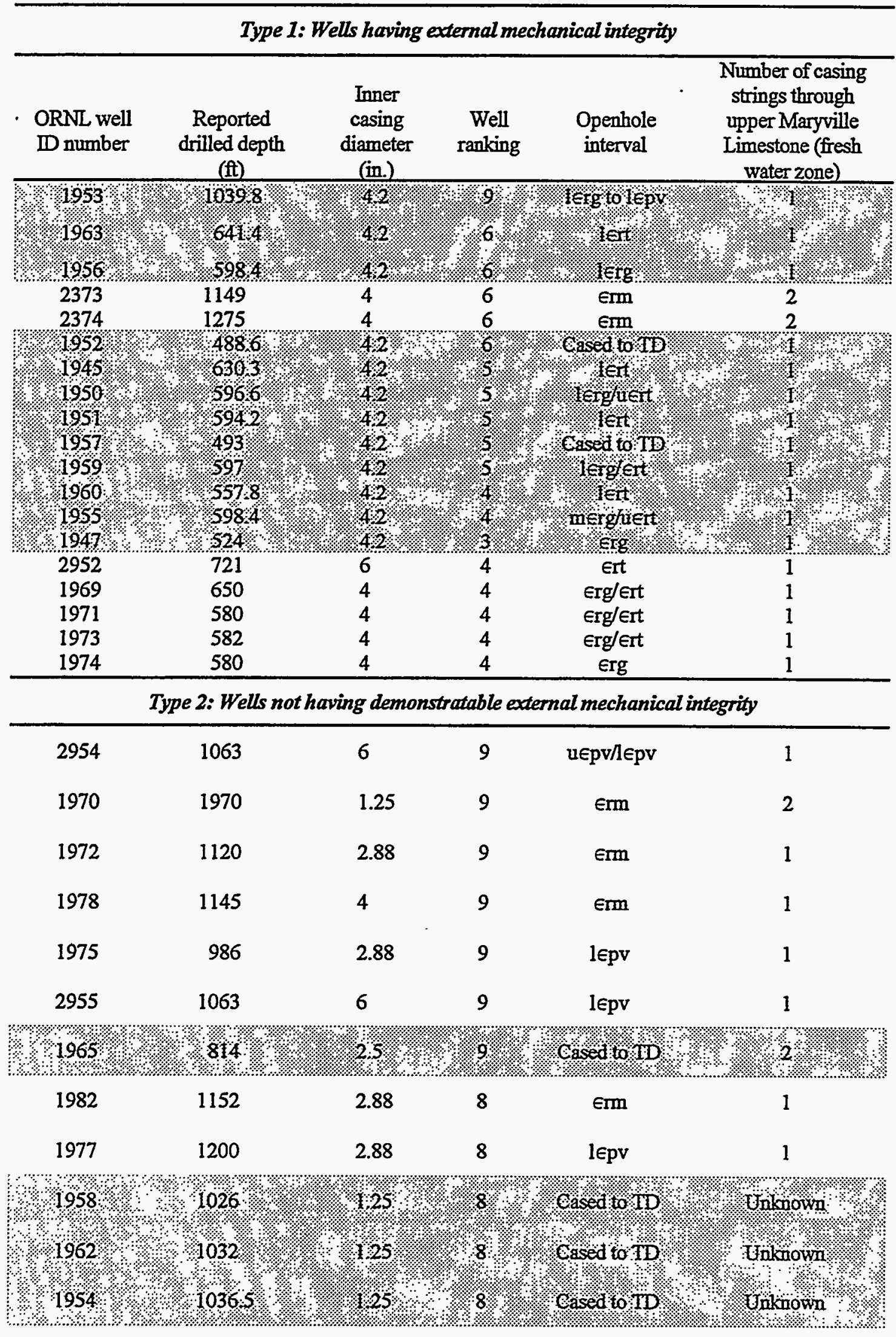


Table 7.3. Classification of New Hydrofracture Facility, Old Hydrofracture Facility, and monitoring wells at HF-2 (continued)

\begin{tabular}{|c|c|c|c|c|c|}
\hline $\begin{array}{l}\text { ORNL well } \\
\text { ID number }\end{array}$ & $\begin{array}{c}\text { Reported } \\
\text { drilled depth } \\
\text { (ft) }\end{array}$ & $\begin{array}{c}\text { Inner } \\
\text { casing } \\
\text { diameter } \\
\text { (in.) }\end{array}$ & $\begin{array}{l}\text { Well } \\
\text { ranking }\end{array}$ & $\begin{array}{l}\text { Openhole } \\
\text { interval }\end{array}$ & $\begin{array}{l}\text { Number of casing } \\
\text { strings through } \\
\text { upper Maryville } \\
\text { Limestone (fresh } \\
\text { water zone) }\end{array}$ \\
\hline 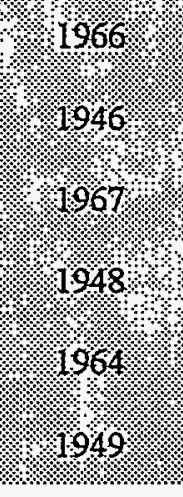 & 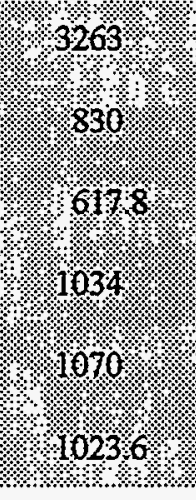 & 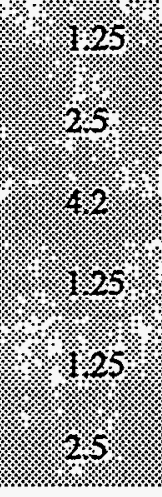 & 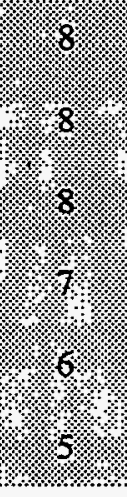 & 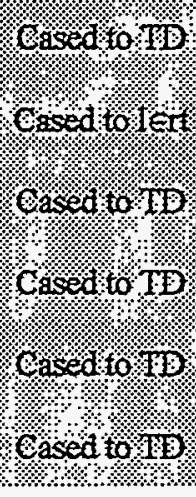 & 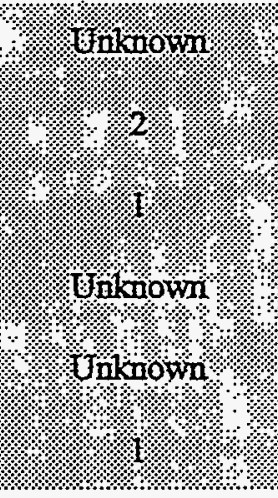 \\
\hline 1981 & 650 & 4 & 5 & erg/ert & 1 \\
\hline 1979 & 700 & 4 & 5 & erg/ert & 1 \\
\hline 1976 & 700 & 4 & 4 & erg/ert & 1 \\
\hline 1980 & 700 & 4 & 4 & EIt & 1 \\
\hline 2953 & 615 & 4 & 4 & $\in \mathrm{ert}$ & 1 \\
\hline 2375 & 910 & 6 & 4 & uepv & 1 \\
\hline 1961 & 494 & 4.2 & 1. & Casedro 10 & $\frac{1}{2}$ \\
\hline
\end{tabular}

Type 3: Uncased openhole monitoring wells at HF-2

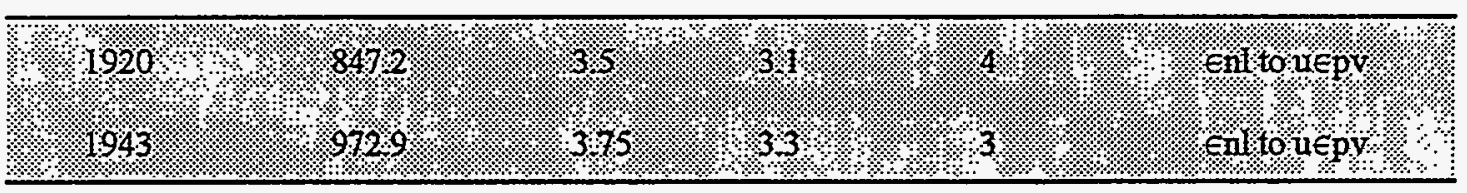

Note: Shaded wells associated with OHF.

$\mathrm{l}=$ lower, $\mathrm{m}=$ middle; $\mathrm{u}=$ upper.

Enl-Nolichucky Shale

emr-Maryville Limestone

erg - Rogersville Shale

Ert - Rutledge Limestone

Epv - Pumpkin Valley Shale

erm - Rome Formation 


\section{CONCLUSION}

The goals of the WAG 10 site evaluation, plugging, and abandonment options report were to:

- rank and classify the NHF associated wells for possible future P\&A,

- recommend the most suitable method of P\&A,

- evaluate the wells as possible candidates for temporary monitoring at the NHF site, and

- refine the WAG 10 conceptual model to support planning for further characterization work.

These goals were accomplished by evaluating historical documents and data, assessing the well pressurization and well water contamination, collecting data to support health and safety and waste management considerations during well P\&A, performing geophysical logging of the wells to evaluate casing and bond integrity, and evaluating the distribution of well contaminants and groundwater constituents to determine potential migration.

A screening-level chemical characterization of the water in the wellbores was performed for each NHF well. The data were used to evaluate and rank the level of contamination, the ability of the casing to prevent an influx of formation water or contamination, and the potential for upward migration of contamination. Headspace pressure data were also collected to assist in evaluating the migration potential within the well. Geophysical log interpretation, in combination with the chemical data, was used to rank wells for future P\&A activities and/or possible temporary monitoring at NHF. To standardize the prioritization and classification process, the same method used for OHF-associated wells was applied to each NHF well; each well was graded based on the nature and level of contamination present, migration potential, and well integrity.

- Twenty-one wells were evaluated in the NHF study. Wellbore water was grab-sampled at three elevations from 20 wells (Well 1970 could not be sampled). Nineteen of the wells were geophysically logged. Observation Wells 1970 and 1972 could not be logged because of smalldiameter tubing and bent riser, respectively.

- Twenty-nine percent of the wells $(2954,1970,1972,1978,1975$, and 2955) received the highest ranking (9) and should be plugged and abandoned as soon as possible. Two other wells (1982 and 1977) received the second highest ranking (8) and should also be considered for eventual P\&A.

- Approval for drilling of a new monitoring well through the grout sheets is highly unlikely; therefore, it would be prudent to use existing wells to further define deep groundwater conditions. Five of the existing NHF wells $(1969,1973,1975,1978$, and 2955) provide an opportunity for retrofitting and sampling/monitoring at the NHF site. These wells have openhole intervals that cover the Rogersville Shale, Rutledge Limestone, and upper Pumpkin Valley Shale.

Geologic cross sections were constructed for the NHF area and tied to the OHF site. Interpretations of these and other acquired data reveal that several mechanisms have been active in the spread of radioactive contaminants associated with NHF operations. They are as follows:

- There is a highly contaminated filtrate plume surrounding the grout sheets within the injection horizon. The plume extends $<1,000 \mathrm{ft}$ to the north and $>1,000 \mathrm{ft}$ to the east and west of the injection well. There is evidence that this plume has migrated since the close of operations at NHF in 1984. The eastern, western, and southern extents are unknown. No surface expression or discharge of associated filtrate or impacted formation water is known. 
- All of the observation wells that penetrate the injection interval were intercepted by grout sheets during NHF operations and are contaminated with grout and/or grout filtrate (aqueous radionuclides). The NHF observation wells provide a potential pathway for upsection migration of contaminants.

- No conclusive evidence of upsection migration of contaminated grout filtrate was discovered in the units that overlie the injection horizon (Rogersville Shale/Rutledge Limestone). Some of the low levels of radiological contamination in the rock cover wells was most likely due to past cross-contamination.

- Radiological contamination present in the standing water column in wells (Wells 2373 and 2374) penetrating into the Rome Formation is "relic" and does not represent downward migration from the grout sheets.

- Most of the wellbores (with the exception of the NHF observation wells) provide a pathway for the upsection migration of high-salinity natural brine.

- Pressurized conditions were encountered in several wells intercepted by the grout sheets. The existence of pressure in the injection horizon provides the gradient necessary to drive contaminant migration, thereby potentially creating a dynamic groundwater flow system.

The goals of the P\&A options analysis portion of this program were to develop well closure activities that would:

- protect health, safety, and the environment,

- protect the shallow freshwater zone (upper Maryville Limestone) and the underlying high saline zone (Rome Formation),

- isolate the injection horizon (upper Pumpkin Valley Shale); and

- minimize exposure risks, waste generation, and costs from P\&A operations.

These goals were met by using the same P\&A technical approach as used for the study of OHF-associated wells. The approach is outlined below.

- The preferred P\&A approach is to leave the well casing in place and fill the entire well in stages with cement for cased wells with external mechanical integrity (EMI; no evidence of flow behind casing). Hydraulic pressure would be applied as needed to force or "squeeze" the cement slurry into formation voids and around casing shoes. The well casing would be pressure-tested to check casing integrity before this method would be used to P\&A a well.

- For those cased wells that do not have EMI or for which EMI cannot be confirmed, the preferred P\&A approach depends primarily on the well casing inside diameter. If the diameter is large enough ( 22.5 in) to accept standard P\&A tools and equipment, the casing and grout sheath will be perforated (by mechanical, explosive, or hydrojetting methods) above the injection zone (if penetrated), at the base of the shallow freshwater zone, and above the underlying formation (if penetrated), and cement will be squeezed into the perforations to form isolation plugs. The intervals below, between, and above the isolation plugs will also be filled with cement.

- If the casing diameter is too small ( $<2.5 \mathrm{in}$.), the well will be cemented up to the base of the shallow freshwater zone (upper Maryville Limestone), and then the casing and annular grout seal above the cement plug will be removed using washover or milling techniques. The newly formed openhole interval created by washover or milling will be filled with cement.

This general approach was used to develop more detailed P\&A descriptions for the 21 WAG 10 NHF wells according to the unique characteristics of each well (Volume 2). The refined approaches were then used to develop generated waste volume and cost estimates. 


\section{REFERENCES}

American Petroleum Institute (API) 1993. Environmental Guidance Document: Well Abandonment and Inactive Well Practices for U.S. Exploration and Production Operations, API Bulletin E3, First Edition. January 31.

Autrey, et al. 1989. Sampling and Analysis of the Inactive Waste Storage Tank Contents at ORNL, ORNL/RAP-53. Oak Ridge National Laboratory, Oak Ridge, Tennessee.

Bailey, Z. C., and R. W. Lee. 1991. Hydrogeology and Geochemistry in Bear Creek and Union Valleys near Oak Ridge, Tennessee, Report 90-4088. U.S. Geological Survey Water Resources Investigation.

BNI (Bechtel National, Inc.) 1988. Remedial Investigation Implementation Plan for the ORNL Waste Area Grouping 10, ORNL/RAP/Sub-87/99053/6. Oak Ridge National Laboratory RI/FS Project, Oak Ridge, Tennessee.

BNI 1990. Remedial Investigation Implementation Plan for the ORNL Waste Area Grouping 10, ORNL/RAP/Sub-87/99053/6\&R2. Oak Ridge National Laboratory RI/FS Project, Oak Ridge, Tennessee.

BNI 1992. Remedial Investigation Implementation Plan for Waste Area Grouping 10 at Oak Ridge National Laboratory, Oak Ridge, Tennessee, ORNL/ER/Sub/87-99053/6/V2. Oak Ridge National Laboratory RI/FS Project, Oak Ridge, Tennessee.

BNI 1994. Reference Sampling for the Remedial Investigation of WAG 5, 05-TB-034. Oak Ridge National Laboratory RI/FS Project, Oak Ridge, Tennessee.

BNI 1995a. Remedial Investigation Report on Waste Area Grouping 5 at Oak Ridge National Laboratory, Oak Ridge, Tennessee, DOE/OR/01-1326\&DO/V1 through V4. Oak Ridge National Laboratory, Oak Ridge, Tennessee.

BNI 1995b. WAG 10 OU3 OHF Well Evaluation Technical Bulletin, 10-TB-001. Oak Ridge National Laboratory RI/FS Project, Oak Ridge, Tennessee.

BNI 1995c. Plugging and Abandonment Options Analysis Report for OHF Wells in Waste Area Grouping 10, Oak Ridge National Laboratory, Oak Ridge, Tennessee, ORNL/ER/Sub/87-99053/77. Oak Ridge, Tennessee.

BNI 1996. Site Characterization Summary Report for Waste Area Grouping 10 Wells at the Old Hydrofracture Facility Oak Ridge National Laboratory, Oak Ridge, Tennessee, DOE/OR/01-1437\&D2. Oak Ridge, Tennessee.

Coobs, J. H. and J. R. Gissel 1986, History of Disposal of Radioactive Wastes into the Ground at Oak Ridge National Laboratory, ORNL/TM-10269. Oak Ridge, Tennessee.

de Laguna, W. et al. 1968. Engineering Development of Hydraulic Fracturing as a Method for Permanent Disposal of Radioactive Wastes, ORNL-4259. Oak Ridge National Laboratory, Oak Ridge, Tennessee. 
de Laguna, W., et al. 1971. Safety Analysis of Waste Disposal by Hydraulic Fracturing at Oak Ridge, ORNL-4665. Oak Ridge National Laboratory, Oak Ridge, Tennessee.

Dreier, R B., et al. 1987. Summary of geological Data in the Vicinity of the Hydrofracture Facilities, ORNL/RAP/LTR-87/26. Oak Ridge National Laboratory, Oak Ridge, Tennessee.

Dreier, R. B., and L. E. Toran. 1989. Hydrology of Melton Valley Determined from Hydraulic Head Measuring Station Data, ORNL/TM 11216. Oak Ridge National Laboratory, Oak Ridge, Tennessee.

Energy Systems 1986a. Investigation of the September 11, 1986, Personnel Contamination Incident at Deep Monitoring Well DMI-PV at the Oak Ridge National Laboratory, K/HS-114. Oak Ridge Gaseous Diffusion Plant, Martin Marietta Energy Systems, Inc.

Energy Systems 1986b. Investigation of Release of Approximately 2 Curies of Strontium 90 to Melton Creek from Exploratory Well S-220, ORNL/RAP/LTR-86-100. Oak Ridge National Laboratory, Oak Ridge, Tennessee.

Energy Systems 1993a. Waste Acceptance Criteria for Radioactive Solid Waste Disposal at SWSA 6, WMRA-WMPC-203. Oak Ridge, Tennessee.

Energy Systems 1993b. Waste Acceptance Criteria for Remote Handled Solid Low Level Waste Storage, WMRA-WMPC-205. Oak Ridge, Tennessee.

Energy Systems 1993c. Oak Ridge National Laboratory Technology Logic Diagram, ORNL/M-2751. Oak Ridge K-25 Site, Oak Ridge, Tennessee.

Energy Systems 1995. Unpublished hydraulic head data from HHMS-series wells.

Energy Systems 1996. Unpublished hydraulic head data from OHF.

EPA 1988. Guidance for Conducting Remedial Investigations and Feasibility Studies Under CERCLA, 68-01-7090. Office of Emergency and Remedial Response, Washington, D.C.

EPA 1989. Risk Assessment Guidance for Superfund: Human Health Evaluation Manual Part A, Office of Solid Waste and Emergency Response.

EPA 1991b. Supplemental Region IVRisk Assessment Guidance, Atlanta, Ga.

Etnier, E. L., E. P. McDonald, and L. M. Houlberg 1993. Applicable or Relevant and Appropriate Requirements (ARARs) for Remedial Action at the Oak Ridge Reservation: A Compendium of Major Environmental Laws, ES/ER/TM-1/R2. Oak Ridge, Tennessee.

Federal Facility Agreement (FFA) 1991. Proposed Federal Facility Agreement for the Oak Ridge Reservation, EPA/DOE/TDEC, Docket No. 89-04-FF.

Geraghty \& Miller, Inc. 1986, Deep Monitor - Well Installation at the Hydrofracture Facility, Oak Ridge National Laboratory.

Gilliam T. M. and J. A. Loflin, Leachability Studies of Hydrofracture Grouts, ORNL/TM-9879. Oak Ridge National Laboratory, Oak Ridge, Tennessee. 
Gilpin, J. K 1992. Oak Ridge National Laboratory Waste Management Plan, ORNL/TM-11433/R2. Oak Ridge National Laboratory, Oak Ridge, Tennessee.

Grove Engineering 1992. "Microshield Version 4, User's Manual." Grove Engineering, Rockville, Maryland.

Haase, C. S. 1983. "Geological and Petrological Considerations Relevant to the Disposal of Radioactive Wastes by Hydraulic Fracturing: An Example at the U.S. Department of Energy's Oak Ridge National Laboratory" in Proceedings of the Sixth Material Research Society Symposium on the Scientific Basis for Radioactive Waste Management. Boston, Mass.

Haase, C. S. 1985. Subsurface Geological Data for the Conasauga Group on the White Oak Mountain and Copper Creek Fault Blocks. DOE Oak Ridge Reservation, ORNL/TM-9159. Oak Ridge National Laboratory, Oak Ridge, Tennessee.

Haase, C. S., E. C. Walls, and C. D. Farmer 1985. Stratigraphic and Structural Data for the Conasauga Group and the Rome Formation on the Copper Creek Fault block near Oak Ridge, Tennessee: Preliminary Results from Test Borehole ORNL-JOY No. 2, ORNL/TM-9159. Oak Ridge National Laboratory, Oak Ridge, Tennessee.

Haase, C. S., J. Switek, and S. H. Stow 1985. Formation Water Chemistry of the Conasauga Group and Rome Formation near Oak Ridge, Tennessee, Preliminary Data for Major Elements, Geologic Society of American Abstracts with Programs, Vol. 16.

Haase, C. S. 1987. Geophysical Data from Boreholes DM1, DM2, DM3, and DM3a, New Hydrofracture Facility, Oak Ridge National Laboratory, Oak Ridge, Tennessee, ORNL/TM-9681. Oak Ridge, Tennessee.

Haase, C. S., J. Switek, and S. H. Stow 1987. Geochemistry of Formation Waters in the Lower Conasauga Group at the New Hydrofracture Facility: Preliminary Data from the Deep Monitoring (DM) Wells, ORNL/RAP-6. Oak Ridge National Laboratory, Oak Ridge, Tennessee.

Haase, C. S., and S. H. Stow 1987. Precise Leveling determinations of Surface Uplift Patterns at the New Hydraulic Fracturing Facility, ORNL/TM-9346. Oak Ridge National Laboratory, Oak Ridge, Tennessee.

Haase, C. S. et al. 1987. Chemical and Radionuclide Data from the DM and Associated Wells at the New Hydrofracture Facility, Fall 1986, ORNL/RAP/LTR-86/95. Oak Ridge National Laboratory, Oak Ridge, Tennessee.

Haase, C. S. and G. A. Gillis 1989. Plugging and Abandonment Procedures for the Oak Ridge Y-12 Plant, Y/TS-531.

Hatcher Jr., et al. 1992. Status Report on the Geology of the Oak Ridge Reservation, ORNL/TM-12074.

HSW Environmental Consultants, Inc. October 1991. Monitoring Well Plugging and Abandonment Plan for the Department of Energy Y-12 Plant, Oak Ridge, Tennessee, Y/SUB-91-YP507C/6; DE92 007588. 
Huang, S. F. et al. 1984. Preliminary Radiological Characterization of the Old Hydrofracture Facility (OHF) at Oak Ridge National Laboratory, ORNL/CF-84/202. Oak Ridge National Laboratory, Oak Ridge, Tennessee.

Hatcher, R. D. et al. 1992. Status Report on the Geology of the Oak Ridge Reservation, ORNL/TM-12074. Oak Ridge National Laboratory, Oak Ridge, Tennessee.

Hilchie, D. W. 1982. Applied Openhole Log Interpretation. Douglas W. Hilchie, Inc., Golden, Colorado.

Keys, W. S. 1989. Borehole Geophysics Applied to Ground-Water Investigations. National Water Well Association, 6375 Riverside Dr., Doublin, Ohio.

Lampton, R. E., R. A. Robinson, and H. O. Weeren 1975, Conceptual Design Report New Hydrofracture Facility, ORNL/TM-4826. Oak Ridge, Tennessee.

Lomenick, T. F, and H. J. Wyrick 1965. Geohydrological Evaluation of Solid Waste Storage Area 6, ORNL/TM-1327. Oak Ridge National Laboratory, Oak Ridge, Tennessee.

McMaster, W. M. 1963. Geologic Map of the Oak Ridge Reservation, Tennessee, ORNL/TM-713. Oak Ridge National Laboratory, Oak Ridge, Tennessee.

Milici, R. H. 1973. "The Stratigraphy of Knox County, Tennessee" in Geology of Knox County, Tennessee. Tennessee Division of Geology Bulletin 70, Nashville, Tennessee.

Moore, G. K. 1989. Groundwater Parameters and Flow Systems Near Oak Ridge National Laboratory, ORNL/TM-11368. Oak Ridge National Laboratory, Oak Ridge, Tennessee.

Moore, G. K., and L. E. Toran 1992. Supplemental to a Hydrologic Framework for the Oak Ridge Reservation, ORNL/TM-12191. Oak Ridge National Laboratory, Oak Ridge, Tennessee.

Moore, G. K. and S. C. Young 1992. Identification of Groundwater Producing Fractures by Using an Electromagnetic Borehole Flowmeter in Monitoring Wells on the Oak Ridge Reservation, Oak Ridge, Tennessee, ORNL/ER-91. Oak Ridge National Laboratory, Oak Ridge, Tennessee.

Myrick, T. E. and S. H. Stow 1987. Remedial Action Plan for ORNL Hydrofracture Operations, ORNL/RAP-9. Oak Ridge National Laboratory, Oak Ridge, Tennessee.

Nativ, R and A. E. Hunley. July 1993. The Deep Hydrogeologic Flow System Underlying the Oak Ridge Reservation. ORNL/GWPO-003.

Newsom, T. J. et al. 1993. Source Areas Investigation Plan and Recommendation for Removal Actions at Waste Area Grouping 5 at Oak Ridge National Laboratory, Oak Ridge, Tennessee, ORNL/ER-165. Oak Ridge National Laboratory, Oak Ridge, Tennessee.

Nielson, D. M. and L. Aller 1984. Methods for Determining the Mechanical Integrity of Class II Injection Wells, EPA/600/2-84/121.

ORNL, 1984. Final Safety Analysis Report for New Hydrofracture Facility at Oak Ridge National Laboratory, ORNL/NF-81/2. Oak Ridge National Laboratory, Oak Ridge, Tennessee. 
ORNL, 1987. Remedial Investigation Plan for the Subsurface Characterization of the ORNL Hydrofracture Sites, ORNL/RAP-7. Oak Ridge National Laboratory, Oak Ridge, Tennessee.

ORNL, 1990. Environmental Guidance Program Reference Book, Safe Drinking Water Act, ORNL/M-1127. Oak Ridge National Laboratory, Oak Ridge, Tennessee.

ORNL, 1993. Waste Characterization Data Manual for the Inactive Liquid Low-Level Waste Tank Systems at Oak Ridge National Laboratory, Oak Ridge, Tennessee, DOE/OR/01-1159\&D1. Oak Ridge National Laboratory, Oak Ridge, Tennessee.

Ossi, E. J. 1979. "Mesoscopic Structures and Fabric Within the Thrust Sheets Between the Cumberland Escarpment and the Saltville Fault" (unpublished M.S. thesis), The University of Tennessee, Knoxville, Tennessee.

Peretz, F. J. 1986. Characterization of Low-Level Liquid Wastes at the Oak Ridge National Laboratory, ORNL/TM-10218. Oak Ridge National Laboratory, Oak Ridge, Tennessee.

Reed, W. R. 1984. Preliminary Decommissioning Study Reports; Volume 11: Old Hydrofracture Facility, X-OE-231. Oak Ridge National Laboratory, Oak Ridge, Tennessee.

Roeder, D. H., O. E. Gilbert, and W. D. Witherspoon 1978. "Evolution and Microscopic Structure of Valley and Ridge Thrust Faults, Tennessee and Virginia," University of Tennessee Studies in Geology, Vol. 2, The University of Tennessee, Knoxville, Tennessee.

Sledz, J. and D. D. Huff 1981. Computer Model for Determining Fracture Porosity and Permeability in the Conasauga Group, ORNL/TM-7695. Oak Ridge National Laboratory, Oak Ridge, Tennessee.

Smith, D. K. 1987. Cementing. Monograph Volume 4, Henry L. Doherty series. New York: Society of Petroleum Engineers.

Solomon, D. K et al. 1992. Status Report: A Hydrologic Framework for the Oak Ridge Reservation, ORNL/TM-12026. Oak Ridge National Laboratory, Oak Ridge, Tennessee.

Stansfield, R. G. and D. D. Huff 1992. Well Plugging and Abandonment Plan for Waste Area Grouping 6 at Oak Ridge National Laboratory, Oak Ridge, Tennessee, ORNL/ER-82. Oak Ridge, Tennessee.

Stansfield, R. G., M. A. Bogle, and M. A. Wood 1992. Plugging and Abandonment Plan for Wells and Coreholes at Oak Ridge National Laboratory, Oak Ridge, Tennessee, ORNL/ER-119. Oak Ridge, Tennessee.

Stockdale, P. B. 1951. Geological Conditions at the Oak Ridge National Laboratory $(X-10)$ Area Relevant to the Disposal of Radioactive Waste, ORO-58. U.S. Department of Energy, Oak Ridge, Tennessee.

Stinton, D. P., E. W. McDaniel, and H. O. Weeren 1983. Characterization of Hydrofracture Grouts for Radionuclide Migration, ORNL/TM-8798. Oak Ridge, Tennessee.

Switek, J. and S. H. Stow 1986. Well Inventory for ORNL Hydrofracture Sites, RAP 86-59. Oak Ridge National Laboratory, Oak Ridge, Tennessee. 
Switek, J., C. S. Haase, and S. H. Stow 1987. Geochemistry of Formation Waters in the Lower Conasauga Group at the New Hydrofracture Facility: Preliminary Data from the Rock Cover (RC) Wells, ORNL/RAP-5. Oak Ridge National Laboratory, Oak Ridge, Tennessee.

Switek, J., C. S. Haase, P. H. Pollard, and S. H. Stow 1988. Chemical and Radiological Data for Groundwaters from Rock Cover wells at the New Hydrofracture Facility, Fall 1986, ORNL/RAP/LTR-87/52. Oak Ridge, Tennessee.

Thornhill, J. T. and B. G. Benefield 1990. Injection Well Mechanical Integrity, EPA/625/9-89/007. Oak Ridge, Tennessee.

Tiegs, T. N.. 1983a. Sludge Injection - 3, Document No. Unknown. Oak Ridge, Tennessee.

Tiegs, T. N.. 1983b. Sludge Injection - 5, ORNL/NFW-83/18. Oak Ridge, Tennessee.

Tiegs, T. N.. 1983c. Injection ILW-20, ORNL/NFW-83/25. Oak Ridge, Tennessee.

Tiegs, T. N.. 1983d. Sludge Injection - 6, ORNL/NFW-83/34. Oak Ridge, Tennessee.

Tiegs, T. N.. 1983e. Sludge Injection - 7, ORNL/NFW-83/35. Oak Ridge, Tennessee.

Tiegs, T. N.. 1984a. Sludge Injection - 1, ORNL/NFW-84/34. Oak Ridge, Tennessee.

Tiegs, T. N.. 1984b. Sludge Injection - 2, ORNL/NFW-84/35. Oak Ridge, Tennessee.

Tiegs, T. N.. 1984c. Sludge Injection - 4, ORNL/NFW-84/37. Oak Ridge, Tennessee.

Texas World Operations (TWO) 1986. Draft Plugging and Abandonment Plans for Wells Associated with the Hydrofracture Sites, Oak Ridge National Laboratory, ORNL/RAP/Sub-86/72140/1.

TWO 1987. Detailed Plugging and Abandonment Plans for Group 1 Wells at the ORNL Hydrofracture Facilities, ORNL/RAP/Sub-87/72140/2.

Unknown, Computerized Pressure Monitoring System at the ORNL Hydrofracture Facility. Oak Ridge National Laboratory, Oak Ridge, Tennessee.

Von Damm, K. L. 1987. Results of Preliminary Geochemical Modeling of Groundwaters from the Hydrofracture Site, ORNL/RAP/LTR-87/40. Oak Ridge, Tennessee.

Webster, D. A. 1976. A Review of Hydrologic and Geologic Conditions Related to the Radioactive Solid-Waste Burial Grounds at Oak Ridge National Laboratory, Tennessee, Open-file Report 76-727. U.S. Geological Survey, Knoxville, Tennessee.

Webster, D. A. and M. W. Bradley 1988. Hydrology of the Melton Valley Radioactive Waste Burial Grounds at Oak Ridge National Laboratory, Tennessee, Open-file Report 87-686. U.S. Geological Survey.

Weeren, H. 1964. Description of Shale Fracturing Pilot Plant and Analysis of Operating Hazards, ORNL-TM-1003. Oak Ridge National Laboratory, Oak Ridge, Tennessee. 
Weeren, H. O. 1974. Shale Fracturing Injections at Oak Ridge National Laboratory 1972 Series, ORNL/TM-4467. Oak Ridge National Laboratory, Oak Ridge, Tennessee.

Weeren, H. O., G. D. Brunton, W. deLugna, and J. G. Moore, 1974, Hydrofracture Site Proof Study at Oak Ridge National Laboratory, ORNL/TM-4713. Oak Ridge National Laboratory, Oak Ridge, Tennessee.

Weeren, H. O. 1976. Shale Fracturing Injections at Oak Ridge National Laboratory 1975 Series, ORNL/TM-5545. Oak Ridge National Laboratory, Oak Ridge, Tennessee.

Weeren, H. O. 1980. Shale Fracturing Injections at Oak Ridge National Laboratory 1977-1979 Series, ORNL/TM-7421. Oak Ridge National Laboratory, Oak Ridge, Tennessee.

Weeren, H. O., et al. 1982, Disposal of Radioactive Wastes by Hydraulic Fracturing, ORNL/CF-81/245. Oak Ridge National Laboratory, Oak Ridge, Tennessee.

Weeren, H. O. 1984a. Waste Solution Injection ILW-19, ORNL/NFW-84/38. Oak Ridge, Tennessee.

Weeren, H. O. 1984b. Sludge Injection - 8, ORNL/NFW-84/12. Oak Ridge, Tennessee.

Weeren, H. O. 1984c. Sludge Injection - 9, ORNL/NFW-84/13. Oak Ridge, Tennessee.

Weeren, H. O. 1984d. Sludge Injection - 10, ORNL/NFW-84/14. Oak Ridge, Tennessee.

Weeren, H. O. 1984e. Waste Solution Injection $I L W-20$, ORNL/NFW-84/15. Oak Ridge, Tennessee.

Weeren, H. O. 1984f. Hydrofracture Injections at Oak Ridge National Laboratory - 1982-1984 Series, ORNL/NFW-84/83. Oak Ridge National Laboratory, Oak Ridge, Tennessee.

Weeren, H. O, et al. 1984g. Recovery of the Injection Well at the New Hydrofracture Facility, ORNL/TM-8823. Oak Ridge, Tennessee.

Weeren, H. O, 1993, Miscellaneous Matters of Importance to Hydrofracture Injections. Unpublished, Oak Ridge, Tennessee.

Zehner, H. H. and P. Tucci 1991. Written communication (Draft of Hydrology of Melton Valley at Oak Ridge National Laboratory, Tennessee), U.S. Geological Survey, Nashville, Tennessee. 


\section{DISTRIBUTION}

1. L. V. Asplund

2. R. K. Davis

3. R. H. Ketelle

4. A. J. Kuhaida

5. L. L. Kaiser

6-8. D. M. Matteo

9. P. T. Owen

10. P. A. Schrandt

11. S. H. Stow

12-13. A. S. Will

14. Central Research Library

15. ER Document Management Center-RC

16. R. L. Nace, Team Leader, Fernald/Ohio Team, Office of Environmental Restoration, U.S. Department of Energy, Cloverleaf Building, EM-425, 19901 Germantown Road, Germantown, MD 20874

17. J. W. Wagoner II, Team Leader, Portsmouth/Paducah/Weldon Spring Team, Office of Environmental Restoration, U.S. Department of Energy, Cloverleaf Building, EM-424, 19901 Germantown Road, Germantown, MD 20874

18-19. R. C. Sleeman, Director, Environmental Restoration Division, DOE Oak Ridge Operations Office, P.O. Box 2001, Oak Ridge, TN 37831-8541

20-21. Office of Scientific and Technical Information, P.O. Box 62, Oak Ridge, TN 37831

22-23. R. M. Pawlowicz, Bechtel National, Inc., Oak Ridge Corporate Center, 151 Lafayette Drive, P.O. Box 350, Oak Ridge, TN 37831-0350 